$80 / 8$

C 


\section{The Bancoft Sibrary}

University of California - Berkeley 









\section{Lester Rowntree}

CALIFORNIA NATIVE PLANT WOMAN

Regional Oral History Office

The Bancroft Library 



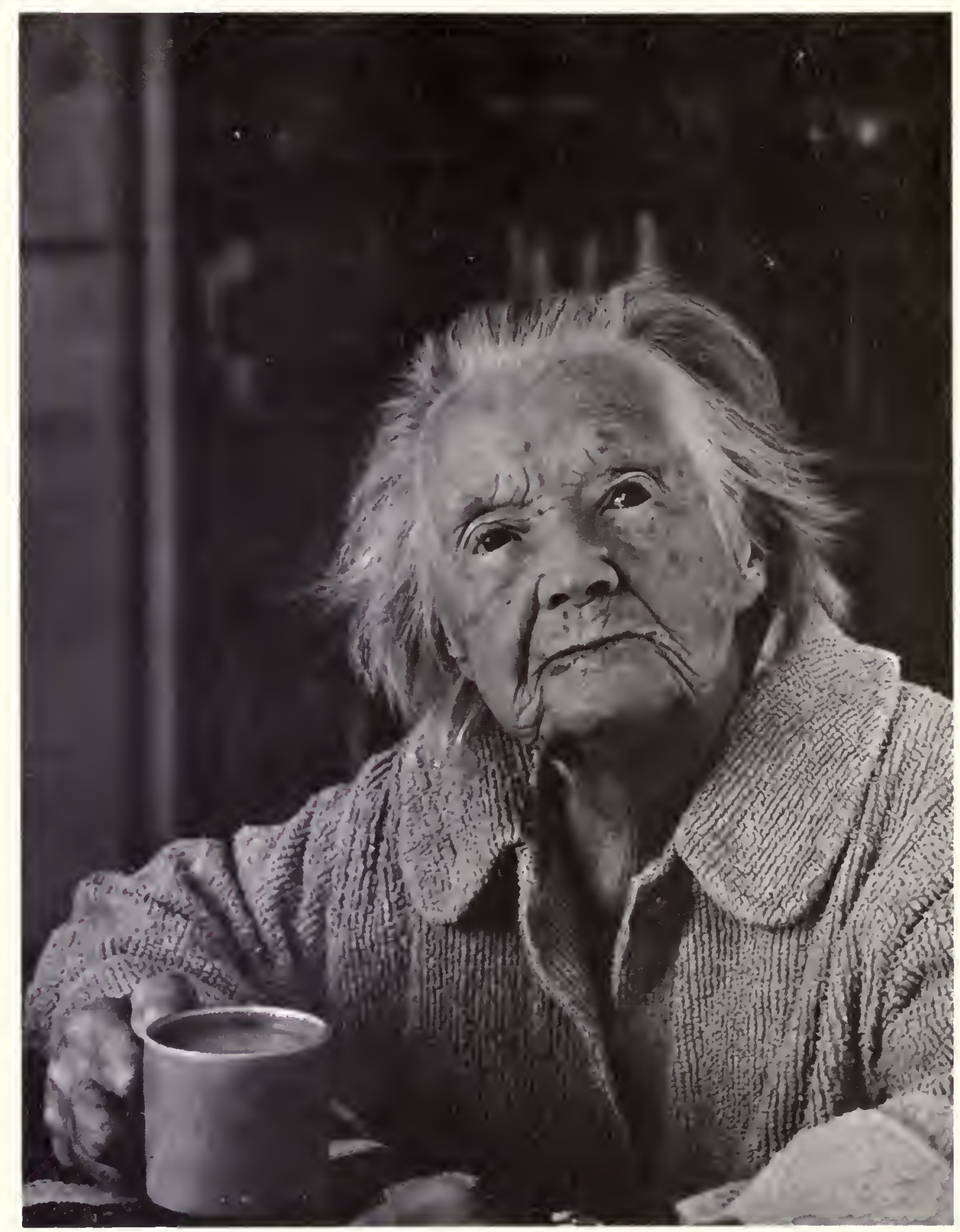

Lester Rowntree at home October, 1978

Photograph by Rosemary Levenson 
Regional Oral History Office

The Bancroft Library
University of California

Berkeley, California

Lester Rowntree

CALIFORNIA NATIVE PLANT WOMAN

Interviews with

Margaret Campbell

Skee Hamann

Heidi Rowntree Melas, with Erika Rowntree

Patricia Rowntree Nash

Robert Ornduff

James Roof

Cedric Rowntree
Harriette Rowntree

Lester Bradford Rowntree

Lester Rowntree

Nancy Rowntree, with Jennifer Rowntree Rowan Rowntree Jo Stallard

\footnotetext{
With an Introduction by

Mildred E. Mathias

Interviews Conducted by

Rosemary Levenson

in 1978
}

Funded by a grant from

The Elvenia J. Slosson University of California Endowment Fund for Ornamental Horticulture 
Copy no. 1

Copyright (C) 1979 by the Regents of the University of California 
TABLE OF CONTENTS -- Lester Rowntree

INTRODUCTION by Mildred E. Mathias

INTERVIEW HISTORY

iii

TABLE OF ILLUSTRATIVE MATERIALS

xii

MARGARET CANPBELL: THE LESTER ROWNTREE ARCHIVE AT THE

CALIFORNIA ACADEMY OF SCIENCES, SAN FRANCISCO

Volunteer Archivist at the California Academy of Sciences,

San Francisco

First Meeting: Lester Rowntree Burning Her Papers

Description of the Collection: Valuable Seed Catalogues

A Note on Lester Rowntree's Background

The Quaker Connection

Seed Collecting

Lester Rowntree's Contributions as Horticulturist and Author

Conservation

Garden Landscaper

Anecdotes and Tales: Lady Byng, Jepson, James West, and Others

Further Notes on the Lester Rowntree Archive

ROBERT ORNDUFF: CALIFORNIA NATIVE PLANTS: A DISTINCTIVE FLORA

California Flora: Young, Rich, Isolated, and Well Studied

Lester Rowntree, Pioneer Promoter of the Horticultural Values of California Native Plants

Botanic and Esthetic Values of the Horticultural Use of California Natives

Carmel a Choice Gardening Climate

Strong Women in California's Native Plant History

Amateur Naturalists and the Pleasures of Knowledge

JAMES ROOF: LESTER ROWNTREE: THE FEMALE JOHN MUIR

Roof Works as Nursery Superintendent for the U.S. Forest Service

Charles Kraebel: Forgotten Man of California Native Plants

First Meeting with Lester Rowntree

Division of Opinion in the Forest Service: "We're Not Pansy Planters"

A Note on the Establishment of the East Bay Regional Park Botanic Garden, 1940 
LESTER BRADFORD ROWNTREE: WALK SOFTLY IN NATURE

Lester's Namesake: Never a Botanist 187

Heavy Expectations 190

Eventful Expeditions: Practical Examples of Intuitive Ecology 191

Denny and the Indian Magic as a Cult Book 193

Lester's Writing Techniques: A Peaceful Jail in the Valley 193

Ego Strength: A Driven Writer 196

A Wry Sense of Humor 198

Tastes in Music 198

Mechanical Aptitudes? 200

Radical Socialist and Traditional Pacifist 200

A Pantheistic Quaker: What Felt Right, She Did 203

Contacts with the Bohemian Community: Lester Valued as a
Genuine Eccentric

Tea and Conversation 205

Hard Labor at the House on the Hill 206

Lester's Spiritual Energy: The Bond with the Granddaughters-in-law 207

A Great-Granddaughter Born in Lester's Bed 208

The Great-Grandchildren and Lester: Happy Feelings 210

Lester's Contributions to Horticulture $\quad 212$

A Role Model for Independent People 212

PATRICIA ROWNTREE NASH: "MEMORIES OF NANNIESTHER" 215

NANCY ROWNTREE, WITH JENNIFER ROWNTREE: "KEEP YOUR PORES OPEN AND KEEP LISTENING" 218

Nancy Meets Rowan Rowntree at the Beginning of Freshman Year, 1956218

Lester Rowntree: "She Would Listen" 219

Lester as Something of a Guru Figure 220

Lester and Ecology: "It Was Still a Word People Had to Look Up" 221

Lester's Extraordinary Perceptions 222

Her Influence on the Family 224

Lester and Imogen Cunningham: "They Passed and Touched" 226

Quaker Background and Spiritual Eclecticism 227

"I Always Feel Her There, Stretching" 229

Reminiscences 231

HEIDI ROWNTREE MELAS, WITH ERIKA ROWNTREE: SHE GAVE AN EXAMPLE 237

A Daughter-in-Law from Salzburg 237

The Grandmother-in-Law: "Somehow We Found a Common Wavelength" 237

A Great-Granddaughter Born in Lester's Bed 239

Troubles with Sleeping Pills and Old Age 243

An Intellectual Reminder Within the Family 245

Lester's Cooking: Chicken, Chard, and Comfrey 249

Travels: Definitely Anglo-Saxon Oriented 250

A Lack of Political Awareness 251 
The Grandchildren's Divorce: Intellectually Acceptable, Emotionally Difficult

A Family-oriented Feminist

A Shared Love of Mozart

Coda

SKEE HAMANN: LESTER ROWNTREE: FRESH, FREE CURRENTS OF LIFE

First Impressions, 1966

"Runaway": How Skee Recorded Lester's Life

Estimation of Her Writings: Conservation

Lester: "I'm Just a Botanical Enthusiast"

Horticulture, Landscaping, and Hybridization 267

California Native Plants

Personal Relations

Strong Influence of the Quaker Tradition 274

Lester's "Feminism"

A Very Deep Experience

JO STALLARD: "SHE WAS SO GOOD" 279

Jo's Ad: "Happy Middle-Aged Lady. . . ", 279

Lester at 93, Perfectly Self-Sufficient

"And Remember, Lots of Butter"

Tastes in Literature and Music

No Use for Tapes for the Blind

Lester's Need to be in Touch with The Hill 288

The Need for a Sense of Engagement: "What Can We Do?" 289

Lester's Reputation in the Monterey Area 291

Views on Women's Lib 293

Dilemmas of Old Age 294

"Jo, When Am I Going to Die?" 296

APPENDIX I - Lester Rowntree's writing "Helps" collected by Margaret Campbell

APPENDIX II - Transcripts of Rowan Rowntree's interviews with grandmother Lester Rowntree.

"Images of the English and American Landscapes," March 1-2, 1969

"A Chat with Lester Rowntree," February 28, 1969

"Some Memories," March 1, 1969

"The Hil1," January 12, 1971 
APPENDIX III - Account of an odyssey with Lester Rowntree, 1935 by Viscountess Byng of Vimy, Up The Stream of Time,

(Toronto: The MacMillan Company, 1946), Pp. 210-217

APPENDIX IV - California Wild Flower Seeds. Two pages from

Lester Rowntree \& Co. brochure, c. 1935

INDEX 
INTRODUCTION

Gertrude Ellen Lester Rowntree followed a historic line of European collectors of California native plants. In September 1786 the botanist on the La Perouse Expedition visited Monterey and collected seeds of Abronia umbellata, sand verbena, to be taken back to France as the first introduction of the wonders of the California flora to the horticultural world. Other collectors followed. Chamisso and Eschscholz in 1816 obtained seeds of the California poppy, Eschscholzia californica. David Douglas, sponsored by the London Horticultural Society, introduced many of California's wonders to English gardens in the 1830's. Among these were Garrya elliptica and Ceanothus species, cultivated by Gertrude Ellen's father in his Cumberland garden, plants that undoubtedly influenced her and her older brother Francis* to devote their lives to plants.

When Gertrude Ellen Lester arrived in Altadena with her family in 1891 it was to view the famous poppyfields on the slopes of Mt. Lowe, acres so brilliant that they are reported to have provided a landfall for sailors entering the harbor at San Pedro. As with most English families the love of gardens was pervasive wherever they lived. Native plants were grown along with exotics and the garden was as important as the house. Gertrude Ellen was collecting and planting wild flower seeds as a young girl and never ceased until partial loss of eyesight along with the infirmities of age made expeditions difficult if not impossible. Yet her own garden continues to be a focus of interest.

Lester Rowntree is a pioneer--an independent woman before ERA. I first met her in the UCLA botanical garden one morning in the late $1940^{\prime} \mathrm{s}$ when the superintendent had arrived to find that Lester, enroute from a seed collecting trip, had spent the night there in her old car. It was an exciting morning walking with her through the garden and hearing of the gems of the most recent collecting expedition.

Lester was also a pioneer in her promotion of the wonders of the California flora. Her Hardy Californians and Flowering Shrubs of California are among the few popular writings resulting from years of observation of California plants both in the wild and in the garden. They are replete with information on habitats and variability of some of our choicest natives. They call attention of the lay reader to the great diversity of terrain and climate and the high percentage of endemism in the Calffornia flora. Through these books, many articles, lectures, and landscaping Lester has made significant contributions to her adopted state. The theme of conservation

*Francis Lester, renowned authority on roses, Carmel, California. 


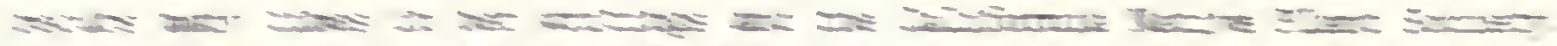

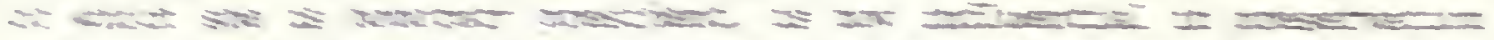

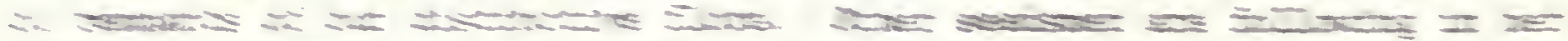

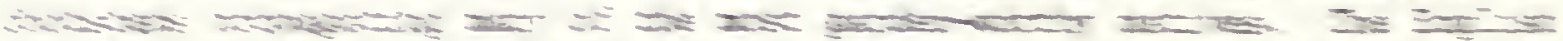

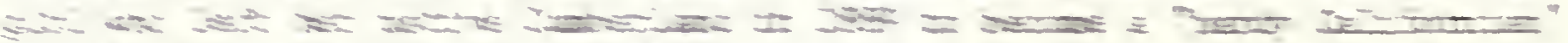

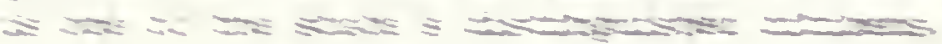
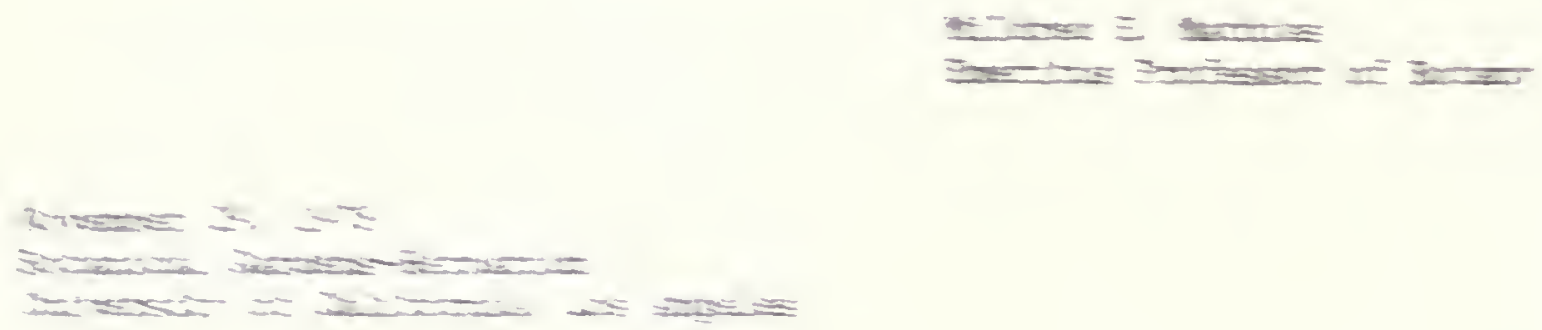


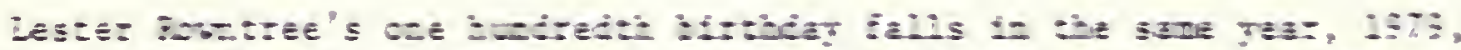

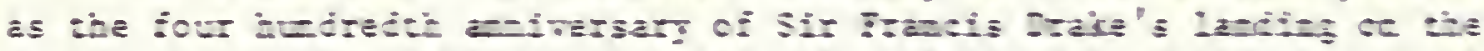

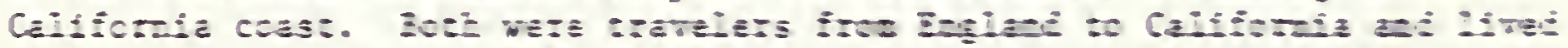

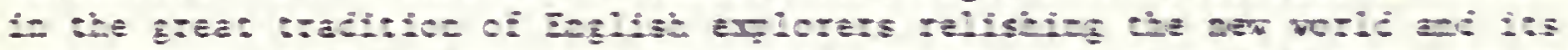

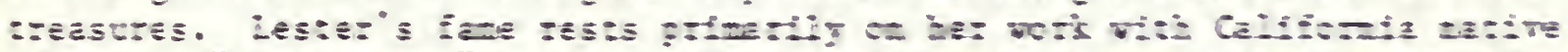

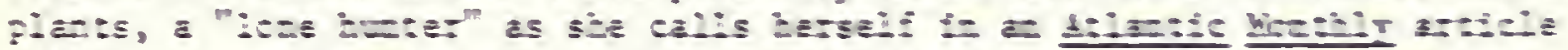

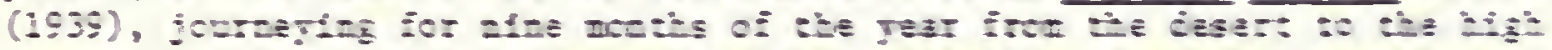

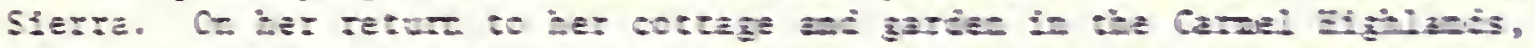

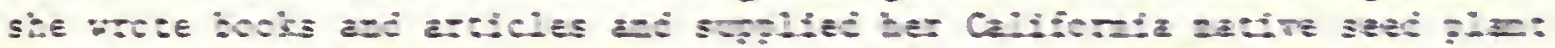

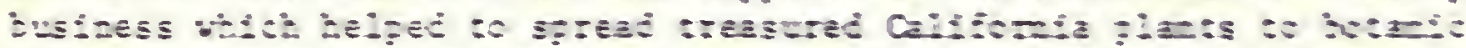

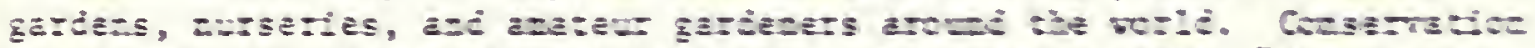

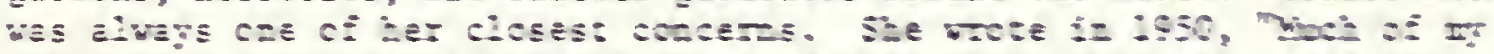

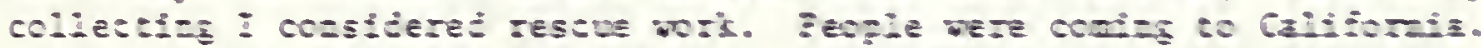

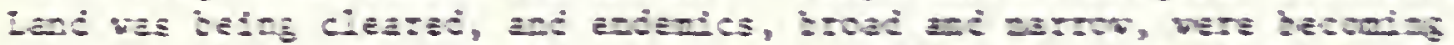

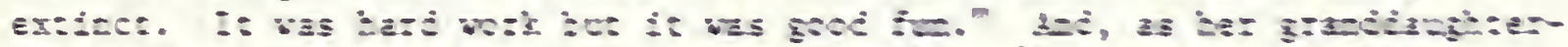

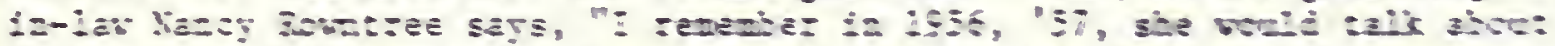

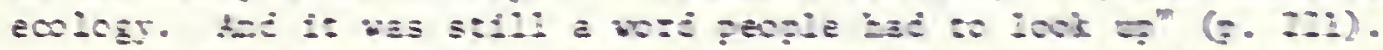

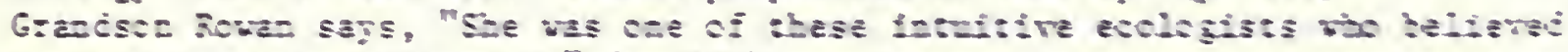

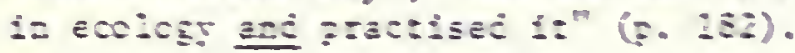

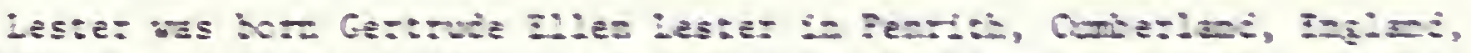

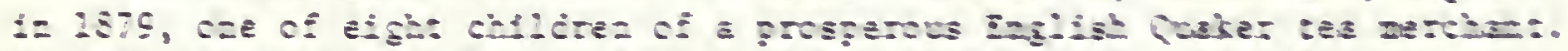

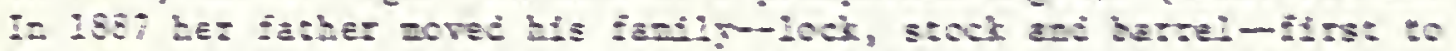
Tauss a

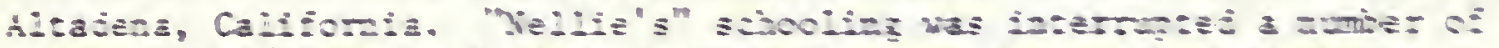

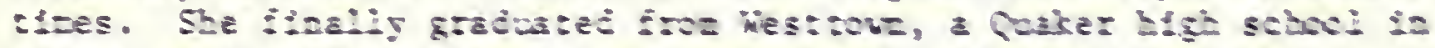

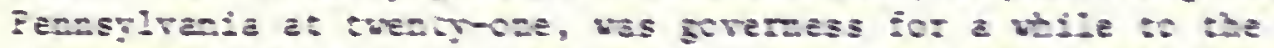

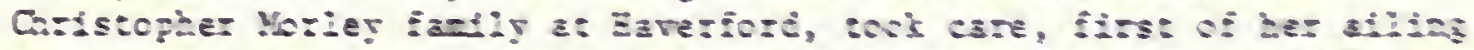

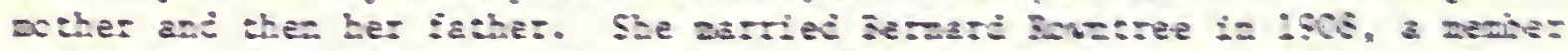

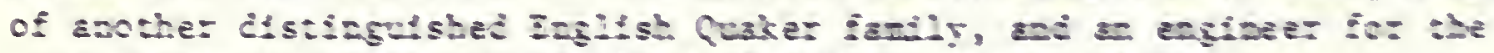

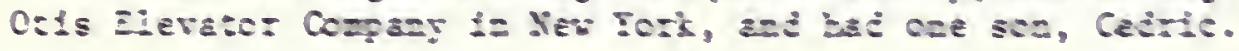

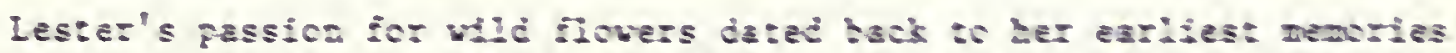

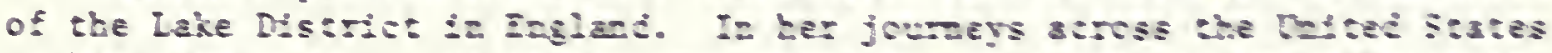

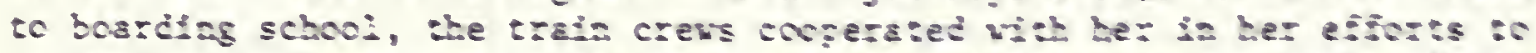

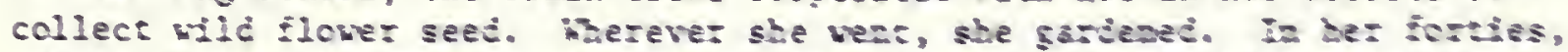
cancer of the utezus is ciegrosed. Afrer surger, lester persuded he:

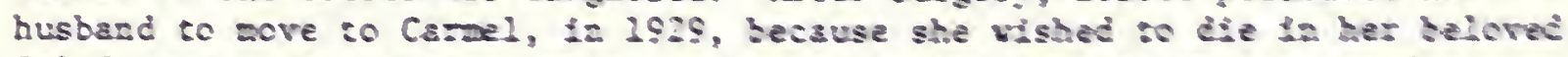

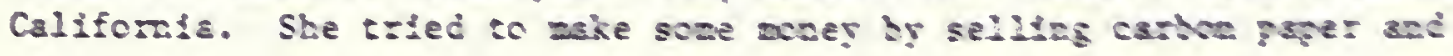


typewriter ribbons. However, neither the business nor the marriage was working. At the age of fifty-three, Lester divorced her husband and started a new career, dropping the names Gertrude Ellen, and taking the androgynous name, Lester Rowntree. Lester had resented the stereotypical female role she was earlier forced to fill, staylng home to take care of her parents while her brothers were educated, but now says that she does not regret her lack of a univers1ty education. "That would spoil everything. . . It would be all what you learned--put on--veneer--pretence."* There are regrets about the marriage, which ended in divorce in 1932.

After the divorce, Lester built a little cottage in the Carmel Highlands where she lived alone and began a life of wandering through the deserts, chaparral, and up into the high Sierra for nine months of every year. She supported herself with writing--over a hundred published articles in fournals ranging from the Journal of the Royal Horticultural Society to local garden club newsletters. She also ran, with the help of a devoted friend, a California native plant seed business. The two books that she published when she was in her fifties, Hardy Californians (New York: The MacMillan Company, 1936) and Flowering Shrubs of Callfornia (Stanford University, Californla: Stanford University Press, 1939), were well received and are to be republished this year (1979) by Peregrine Sulth. Three other book length manuscripts on rock gardens, desert plant life, and Lester's own garden did not find a publisher, and can be read in manuscript in the Rowntree Archive, California Academy of Sciences, San Francisco.t Arother book length manuscript was consumed in a fire in her writing studio.

She toured beyond the state of Calffornia into Canada and Mexico and most of the states of the continental Untted States, supporting herself by lecturing to garden clubs and schools, sometimes subsisting on ten cents a day for chicken feed which she boiled and ate as gruel. She spurned conventional comfort at home or in the field, but insisted on her daily bath whether in an icy mountain lake, the ocean, or wherever she might be.

Another small source of income was Lester's landscaping. Her first garden at The Rowans, Oradell, New Jersey, still showed the formal influence of the Tudor walled garden and the conventional well-stocked Victorian perennial herbacious border. (See 1llustration following p. 80.) It was not until lester built her own cottage in the Carmel Highlands that she developed her style in the direction pointed by Lancelot (Capability) Brown, the great English natural landscape architect of the eighteenth century.

*Iester Rowntree, Hardy Californian, f1lm documentary sound track.

$+A$ card catalogue of Lester's published articles is also in the archive. 
Lester used malnly native plant material in conformity with existing contours, an approach with strong Chinese resonances, well suited to the rugged Callfornia coastline. Grandson Rowan says, "[S] he placed value on native plants. That's saying more than fust the fact that you ought to use native plants because they'll grow better, take less water. She valued things that were natural--things that were in their place--things that fit" (p. 181).

The career that Lester started at fifty-three began to peter out in her late seventies as faling eyesight made long, solitary car trips and close botanic observation less and less practicable. So Lester started a new career of writing children's books, four of which were published. Interestingly, as grandson Lester noted, Denny and the Indian Magic (New York: The Viking Press, 1959) became something of a cult book. "It became sort of the centerpiece of a number of parties where people would get high by varlous means and then pass the book around, reading passages from 1t, and sometimes elaborating on passages as they took on characters, - . and just using $1 t$, as I said, as a centerplece for a kind of a mystical, back to nature experience" (p. 193).

At elghty-nine, 1t became difficult for Lester to manage all the details of house and garden, so her son and daughter-in-law, Cedric and Harrlette, enlarged the cottage and moved in with her, with Lester's sometimes reluctant consent. Lester stayed in her old quarters until it became safer for her to move into the lower apartment where there was less risk of her falling. Both Cedric and Harriette speak honestly and movingly of the problems of aging and the difficulties involved in the combination of two independent households. "I found it awfully hard, as did Cedric, to understand why people still kept coming and sitting admiringly at her [Lester's] feet, when we knew it was just a record that she was giving out. She was fust repeating over and over again the things that we have heard all of these long years. It's very hard for a son and a daughter to see the change in this person who has been Mother and to whom we have deferred, and then find that you have a child on your hands some days" (p. 146). As Lester falled, and wandered more in body and mind she was moved, in December 1978, to the Carmel Convalescent Home where she is constantly visited by famfly and friends..

She was a cultivated and well read lady in many fields, and had a passionate love of music. Though never a political activist, she identified herself with intellectual socialist and traditional pacifist causes, and was friendly with many members of the Monterey and San Francisco Bohemian groups.

The influence of Lester's Quaker background remained strong, although she rarely attended Neeting once she returned to California in 1929. In her hundredth year, she said that what she kept of her Quaker teachings were, "Love of nature, I think--for the good of a place--and then it's all right to run.away--take long walks alone. . Oh, the foy of being alone and out-- 
way out" (Pp. 87-88). She became increasingly interested in Eastern religlons. She called her central religlous princlple by different names but the messages remained the same, the essential unfty of nature in all its forms and the responsiblilty that each person must assume for his own odyssey. As she wrote to a friend in 1964, "Surely you belleve there must be some Big Force behind all beauty and of 1 ts spark the Central light, we each of us carry. This source is there to be used and we are its diamonds. It is so true and so utterly simple. If we clear some of the trash away and bare ourselves to 1 ts influence, help is sure to come. The amount of help 1ncreases as $1 t$ is used and as 1 t is needed. This process is necessary to growth." Her body started to fall but her spirit remalned mostly undaunted. In her hundredth year she sald to me, "If you want to do a thing, make no bones about 1t, just do 1t. That's the big secret. There is no secret. It's all there for free."*

She has thought a great deal about death and says that she has wanted to die for a long time. "Dylng will be nice. You Just step over the line into another world and it's very nice. You just step over into another room. There's not much change if we've lived straight. It depends how we've lived."*

Her formal honors in the worlds of horticulture and conservation include belng elected as Honorary Secretary of the Brftish Alpine Society, Honorary Life President of the California Native Plant Soclety, Presidentat-large of the American Herb Soclety, and a national award from the American Horticultural Soclety which cited Lester for the "Conservation and propagation of California flora, famous as author, photographer, and lecturer, and chlldren's author. A truly great personality of horticulture."

But somehow the formal language of these honorffic citations seems to smudge the Image or images of Lester Rowntree. The interviews in this volume give the plcture of a vital, troublesome, religlous, and deeply loving woman, perfectionist as witer, photographer and horticulturist, wilful, selfish, and generous in her human contacts, widely read, cultivated and open in her musical tastes, and myopic to the point of disaster in some of her human relationships.

To some extent she became a guru-like flgure. P1lgrims would hike up the tortuous roads from the coast road and be recelved. "She did have tremendous Influence. I think that maybe nobody wlll ever know how many people ahe influenced. I think maybe nobody w11l ever know how many people came by that house. People would drop in. They would hear about Lester.

*Lester Rowntree, Hardy Californlan, documentary sound track. 
They would come and they would say, 'Well, I heard about you from a friend, and I was hitchiking up Highway 1 , and I just wanted to meet you.' She became for a lot of people, sort of a guru" (p. 220).

From this tale, as Beatrix Potter would have called 1t, of a genuine Victorian eccentric, many people can learn. "Hell itself will yield to industry," wrote Lester. By her own life, she demonstrated that in one's fifties and seventies a person can start new careers. "People would ask The if I was afraid. I've never been afraid in my life. Fear attracts the thing you are afraid of."*

Planning and Research

Lester Rowntree's name had been suggested a number of times to the Regional Oral History Office of The Bancroft Library as a worthy memoirist. Each time the proposal was enthusiastically recelved but faltered for lack of funding. Fortunately, Elizabeth Nasset, then president of the Berkeley Garden Club, pursued the question, Dean Lincoln Constance was consulted, and recomended an application to the newly formed Elvenla J. Slosson University of California Endowment Fund for Ornamental Horticulture. The advisory committee responded promptly and generously to the application, and later approved a supplementary grant for the making of a documentary film.

The name Lester Rowntree turned out to be an open sesame. The interviewer was generously helped by advice from botanists, horticulturists, the Rowntree family, and Lester's friends. Alice Howard, of the University of Calffornia Herbarium, August and Susan Fruge, of the California Native Plant Society, were generous with time and wise advice, as were many others. Margaret Campbell, whose interview comes first in the volume, deserves a special mention. In her capacity as volunteer archivist at the California Academy of Sciences, San Francisco, she persuaded Lester to donate her papers to the Academy. Margaret learned a great deal about Lester's family background and professional and personal lives in the course of ordering the papers and created an invaluable research resource in the Rowntree archive.

In April 1978, before the proposal had been formally approved, a preliminary visit was made to the Rowntrees in Carmel Highlands, and was valuable in providing an opportunity to form a friendship with Cecil Rowntree, Lester's son, and her daughter-in-law, Harriette. At that time, Lester was

*Ibid. 
still in her origlnal rooms in the upper part of the house. She recelved me, lying on a sofa. Her eyesight had become very poor, and her energy was limited, but her sharp wits, touches of imperiousness, and general good humor seemed untouched by the passage of time. The recording made that day was unfortunately too poor, technically, to transcribe, partly because a throat mike was not used due to Lester's supposed ingrained hostility to technical gadgets (see p. 177).

Shortly after this preliminary visit, Lester fell and hurt her back, spent a few days in hospital, and was then transferred to a convalescent home. It seemed that such an accident to a lady in her hundredth year meant that the project would have to be abandoned. But Lester rallied, as she had so many times in her $11 f e$, retumed home to the lower apartment where risk of falling was reduced, and resumed her peaceful enjoyment of the beautiful air from her garden, the ocean, and the hillside, and the birdcalls, the senses of hearing and smell to some degree compensating for her failing sight.

It was decided to conduct a number of interviews with Lester's famlly, frlends, and professional colleagues. Margaret Campbell, the Rowntree archivist, Professor Robert Ornduff, botanist, native plant enthusiast, and head both of the University Botanical Garden and the Herbarium at Berkeley; Jim Roof, quondam director of the East Bay Reglonal Parks Botanic Garden, all gave personal and scientific insights into Lester Rowntree and her contributions to the interlocking fields of conservation, horticulture, and ecology. These interviews are aptly prefaced by Professor Emeritus Mildred Mathlas's volume introduction, which clearly frames Lester in the history of botanic exploration in California and the West.

Then Lester speaks in her own voice, taped on a Nagra recorder, courtesy of the Educational Television office during the making of the documentary, Lester Rowntree, Hardy Californlan, the raw footage for which was shot in July, 1978. The family Interviews, son, daughter-1n-law, grandsons, their wives and daughters, form a frank and Rashomon-like panorama of shifting images of a powerful, loving, frequently destructive, and inspiring woman. She held onto many of the values growing out of the large Victorian family, while deliberately enjoying the flouting of convention when it suited her. Th1s, too, was a part of the eccentric Victorian tradition.

The last two interviews with frlends who came to Lester late in her life, Skee Hamann, freelance botanic writer and ardent naturalist, and Jo Stafford, a self-designated "Happy Middle-Aged Lady", who stayed with Lester a number of times, round out the picture of an indomitable adventurer. A brief descriptive note precedes each interview. 


\section{Editing and Completion}

Marle Herold completed the stenographic chores with enthuslasm, accuracy, and pithy suggestions. She also accompanied the interviewer on a trip to Carmel to visit Lester in October, 1978, when the portrait which forms the frontispiece to this volume was taken. Lester was still alert, though she tired rapidly, but one last tea party was enjoyed by the three of us.

A speclal note should be made of the appendix materlal. Lester Rowntree's career as a published writer did not start t111 she was In her fifties; correspondence in the Rowntree archive shows that she collected a large number of rejection slips. Her pertinacity was rewarded. She published six books and over a hundred articles. Part of her methodology is 1llustrated in Appendix I, "Helps." She would write telling phrases at any time of the day or night on any scrap of paper that came to hand. Thanks to the patience and skill of Margaret Campbe11, the cream of this enormous crop of jottings has been skimmed, and is presented in legible form. Good and surprising phrases like, "Fundamental drama of the rock garden," "Knotty nomenclature," and "Don't use dry bread when you can get caviar," entertaln. Others, such as, "One never knows how good an idea is unt1l it has appeared in [print] public. In the mind of its originator it may appear a brilliant star but when thrown to meet the reader's eye it becomes drab and bereft of sparkle," Instruct.

Rowan Rowntree describes how he came to intervlew his grandmother when she was ninety, and graclously agreed to let us reproduce those 1969 interviews as Appendix II. Lester's reminiscences roam from her childhood, (Booker T. Washington came to her parents' home in Cumberland) to the present. She speaks about her writing. "Flowering Shrubs . . . was the better book. It had to be written simply because nothing had been done yet. . . But you have to be discriminating and chuck out a lot of stuff." A 1971 note describes a poignant and pivotal emotional experience of Lester's childhood. When she was aboui eleven years old, she met one of her brothers on the stalrcase. "She felt such an upwelling of love for him that she said to him, 'I love you' and he was astonished. After a moment's silence he responded by reprimanding her and saying, 'You are a disgrace to the family; you should never express your emotions like that and you should never wear your heart on your shirtsleeve."

Appendix III consists of excerpts from Viscountess Byng of Vimy's autoblography, Up the Stream of Time (Toronto: The MacM1lian Company, 1946). Lady Byng, who was an outstanding woman in her own right, was marrled to Jullan Byng, seventh son of the Earl of Strafford. He was a regular army officer, was made a viscount in 1926 for his services as Commissioner of the (London) Metropolitan Pollce, and was promoted to Field Marshall in 1932, a singular honor in time of peace. Lady Byng, 
author, distinguished horticulturist, and co-founder of the Alpine Garden Society of Great Britain, apparently made two trips with Lester Rowntree. A well 1llustrated article, "Californla Jottings," was published in three 1ssues of the Journal of the Royal Horticultural Society, 1935, vol. IX, parts 7, $8 \& 9$. She speaks of (p. 368) "[t]he cheerful prospect of another [1talics added] journey with Lester Rowntree, which started March 12, In warm sunshine but with a lightly clouded sky that gave an opalescent effect to the atmosphere as we trundled towards the Bakersfleld district north-east of here and famed for 1ts wild flower display. But I seem 'hoodoo' to the Rowntree car as I was three years ago. . ."

Appendix IV consists of a reproduction of part of one of Lester Rowntree \& Co.'s Californla Wild Flower Seed brochures, n.d., probably c. 1935. Seed packages cost twenty-five cents, postage pald; mlxtures for eight different environments were avallable for fifty cents, and correspondence was invited. "We w1ll be very glad to hear from experimental planters who will report to us on the hardiness of our varleties in the East."

After transcribing, all interviews were edited and returned to the interviewees for their corrections and approval. They responded with varying degrees of promptness. Illustrations were assembled and the volume proofed and Indexed. All the tapes have been deposited in the Rowntree archive, California Academy of Sclences. A copy of Lester Rowntree's tape can also be found in The Bancroft Library.

Lester Rowntree: Hardy Calffornian, a Documentary

The half hour documentary film, Lester Rowntree: Hardy Californian Is now being edited by Rosemary Levenson and Paul Rush of the Educational Television Office, University of California, Berkeley. A three man team with Rosemary Levenson spent three days in Carmel in July, 1978, shooting conversations with Lester Rowntree over tea and on the lower deck of her cottage. Her son, Cedric, describes some of the labors involved in bullding the hillside garden, and Harrlette, his wife, tells some vivid anecdotes of Iffe with Lester. Lyrical passages show the views from Lester's hill of the rocky Carmel coastline, wlld flowers above her cottage, and the magical beach at Yankee Point where she used to take her daily swim in the cold Pac1fic Ocean. Family photographs of the Lester and Rowntree families going back over a hundred years in England and America add a quality of historical depth to this interesting extension of conventional oral history documentation. 
Coda

As this interview history is being written, the University of Calffornia honors Lester in another showcase. To celebrate the four hundredth anniversary of Drake's landing on our Californla shore, the Main Library has mounted an exhibition, Nova Albion, celebrating British contributions to California history. From one of the cases on "Botanists," Lester Rowntree's wise face shines out in company with the eighteenth and nineteenth century figures of Menzles, Nuttall, Jeffrey, Lobb, Douglas, John Mulr, and others.

Perhaps she wrote her best epitaph in a 1950 article in Nature, "The ground became my resting place, the sky my ceiling, and the sun my only cloak."

Rosemary Levenson

Interviewer-Editor

19 February 1979

Regional Oral History Office

486 The Bancroft Library

University of California at Berkeley

LESTER ROWNTREE: February 16, 1879 - February 21, 1979

Today Lester Rowntree died in her sleep, five days after celebrating her hundredth birthday. Queen Elizabeth II sent a cablegram to her aubject (Lester never gave up her Britlsh cltizenship) in honor of the occasion, but Lester's real celebration had taken place a few days earlier. Some friends had driven her from the convalescent home to spend an afternoon in the sun on the deck of her cottage. They served her tea; there was very little talk. A Mahler record was played, and one by one, early spring flowers blooming in the fugltive February sun were handed to her to smell and savor. One friend said, "I never truly knew what the word absorption meant unt1l I saw Lester absorb her garden." Now the garden w111 absorb Lester. By her wish, her body will be cremated and her ashes scattered over the Hill she loved and tended. 
Frontispiece. Portrait of Lester Rowntree in her one hundredth year Congratulations from President and Mrs. Carter and Queen Elizabeth's Private Secretary on Lester Rowntree's one hundredth birthday

Obituaries

Samples of Lester's field notes on backs of bank slips

Four family and school photographs

Lester Rowntree's packing lists for car and burro trips

Lester Rowntree, landscape architect

Itemized records of expenses for round trip by car, CarmelVancouver-Carmel, for two, 1946. Total \$111.65

Six photographs from family albums: The Rowans, house and garden, New Jersey, Bernard, Lester, and Cedric Rowntree, Lila Clevenger

Pencil sketch of Gertrude Ellen Lester, aged fourteen, by her artist brother, Leonard Lester

Seven photographs: Carmel houses, the garden on the Hill, Lester, 1926-1940

Lester's carbon paper sales business

Six photographs. Lester Rowntree, collector and explorer, 1931-1963

Conservation data compiled for the California Garden Clubs Inc. 1937, by Lester Rowntree. Cover, introduction, District 4 list, corrected proof, and letter

Five photographs, Lester Rowntree lecturing, with Josephine Jackson, and at home, 1962-1973 


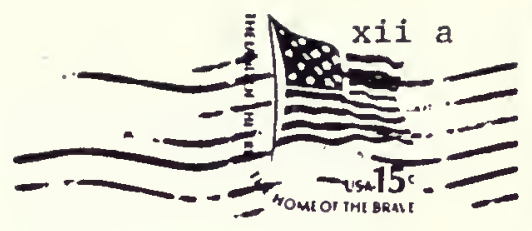

Mrs. G. E. Lester Rowntret

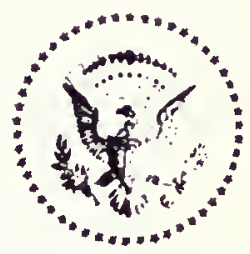

We are pleased to congratulate you on your birthday. You have our best wishes for happiness on this special day and in the year to come.
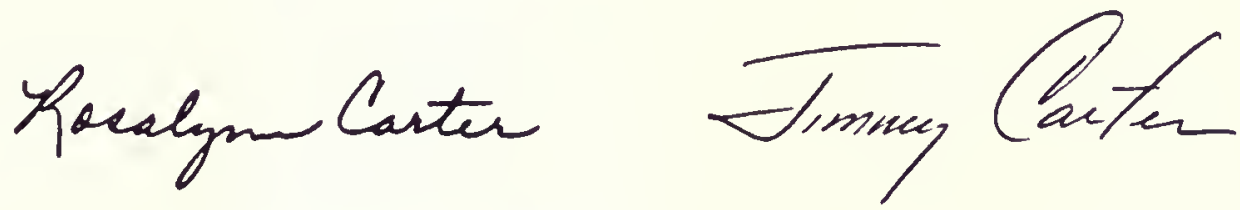

WU AGT CARM

SFC 158(1141)(1-B11929NB 47-BB1)PD $02 / 16 / 79 \quad 0425$

ICS IPMSFSF SFO

SUSPECTED DUPLICATE: 1-B43120GBA7 SFD B58 ICS IPMIIHA IISS

IISS FM RCA $16 \quad 8425$

PMS CARMEL CA

eT

WUC3726 RMM2364 RMD578I UXS453 LHCB5B TLHBB3 A4I

URIX CY GELH 838

EUCKINGHAM PALACE $38 / 3516 \quad 848$

ETAT

MRS LESTER ROWNTREE ROUTE' I BOX 210

CARMEL

CALIFORN I A (93923)

I HAVE RECEIVED THE QUEENS COMMANDS TO SEND YOU HER MAJESTYS

WARM CONGRATULATIONS AND GOOD WISHES ON THE CELEERATION OF YOUR

HUNDREDTH BIRTHDAY

PRIVATE SECRETARY

COL ETAT 121093923

NNN

NNNN 


wia Native Plant Woman,"

\section{Lesfer Rowntree}

\section{Carmel}

Lester Rowntree, a ploweer environmentalist who specisilized in botany, died yesterday at Carmel Convalescent Hospltal. She turned 100 last Friday.

Mrs. Rowntree was borp cer. trude Ellen Lester in Perrith England, but the al ways hated ter first name and began calling her. self lester when whe was a young vomso.

She caine to Calfornia ihortly ifter ber marriage to Bernard frowtree, wham she divorced in 1930.

Hri. Rowatree never remarried. After ber son, Cedric, was grown, she devoted herself to botany, collected seeds from throughout the United States and supplied them to botanical gardens and arboretums.

She wrote numerous articles for scientific journals.

-Mrs.- Rountree was bonorary life president of the Califoraia Native Ptant Society.

She is survived by her son, of Carmel Highlands, three grandchil. dren ind wht groutgrendchil. dren.

Mbernopies, thine will be no funerd pervece fore thed that she be cremated und het shos scat. tered of her poperty 1 sarmel Fighlonds. :T-

The limily aggested contribu. totes to the Chafornti Nattre Plant icemortad Fund, Sutte D, 2300 Ells. warth pets Berketty 94704
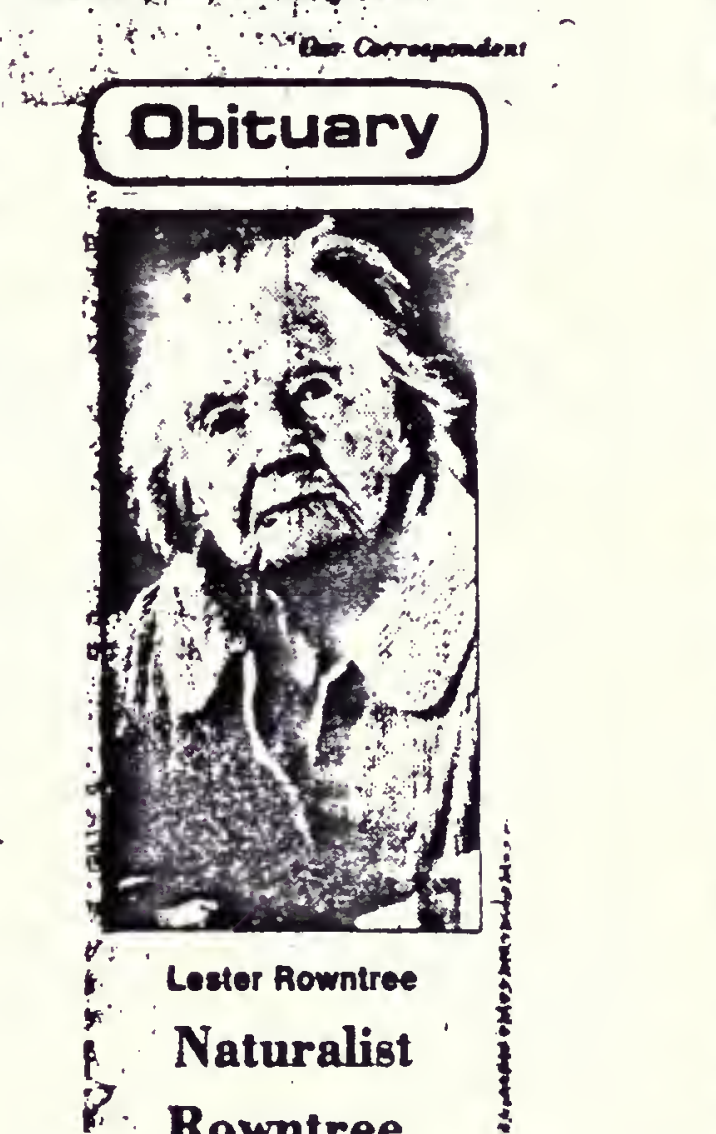
Which is being completed - Rosemary levenson of ine Regional Oral History Bifice of the Bancralt LibTary. The hall-hour acumentary is due 10 be Feleased in June of this: trear.

2 Barn Gertrude Ellen bes. ter in England on Feb. 16, 1.1079, to a well-known tea merchant family, her fam7 Ay moved to California in: 1687. She graduated from? - Westlown School, Penn., in . 1902, and later married Bernard Rowntree. Mrs. Rowntree's love of Wild flowers started in Eng. land, but it was California's : flora that became her: Hfetime passion. When the : ${ }^{12}$ California Native Plant:

Soclety was formed, she :

was named its bonorary:

1 president for her services to

1. the conservation and propagation of California's $\therefore$ plants. She also received a : - oumber of honors from - leading British and American horticultural societies.

She began her career as athor, lecturer, and Califarnia wild flower seed supplier at the age of 53 when she divorced ber hus. : band. Mrs. Rowntree built a cottage in. Carmel High. lands, and started to crisscross the state by car, burro, and on loot, for nine months of the year. The garden she built on her rocky hillside, using mainly - California native plants, became world famous. Her books, Hardy Californians c. and Flowering Shrubs of Califarnia both published in the 30s became minor clas. sics. She also published 1. over 100 articles in a vari. cy of journals. In her 70s, when failing eyesight began

to make botanic expeditions difficult, she wrote and pubIished four children's books.

Survivors include her son, Cedric; three grandthildren and eight great . Irandchildren.

Her ashes will be scat. thered over the Carmel High. lands, and no services will ibe held. The family nuggests memorial conCributions to the California Wative Plant Society, 2880 Ilswarth St., Sulte D, Ber. 
Margaret Campbe11: Volunteer Archivist at the California Academy of Sciences, San Francisco

The interviewer had consulted several times with Margaret Campbell during May, 1978, in the beautiful upper floor of the library of the California Academy of Sciences in Golden Gate Park, San Francisco. Margaret had been responsible for saving the Rowntree papers when Lester decided to start burning them (pp.3-4), and had subsequently organized the archive and made it accessible to researchers. It proved an invaluable tool in preparation for this and subsequent interviews.

The interview took place in the Campbe11s' lovely house in the Oakland hills on June 14, 1978. We worked at the dining room table, stacks of paper by each of us, surrounded by English antique furniture and flowers. An informal agenda was prepared to guide the interview, and was loosely adhered to.

The extraordinary and unassuming contributions that volunteers have made to the advancement of science is a theme that recurs throughout the volume. It is firmly stated in this first interview. Mrs. Campbell describes the manuscript collections as they were in 1965 when she started work as a volunteer in the Academy library. "Mr. Bryan became the librarian. He turned the staff loose on the top floor of the stacks, which was nothing but huge collections of books and papers given by people. We sorted books and papers for months.

"So, all of a sudden, I had everybody's papers to handle, and it was pretty hectic for a couple of years, but we finally got this thing under control. As I say, this archive is not a formal set-up. Each one of these is open-ended and material comes in all the time. So that is the best I could do with it" (p. 2).

The Rowntree papers included a remarkable collection of seed catalogues which almost doubled the library's catalogue collection. Lester specialized in English, Mediterranean, and South African catalogues (pp. 4-5). The English catalogues are of particular interest as they show which American wild flowers had been brought over and were being bred successfully in English nurseries. 
The Rowntree archive consists of boxes of correspondence, three book length manuscripts, numerous articles, published and unpublished, card catalogue of published articles, diaries and ephemera. Of particular interest are five boxes of Lester's photographic record of California native plants. Lester's books and articles were illustrated with her own prints. What remains in the archive consists primarily of meticulously labelled negatives. There is also a small collection of color slides used by Lester in her lectures.*

After transcribing and editing, the interviews were pruned again by Margaret and returned for final typing and indexing by the end of August.

*To be added to the Rowntree archive are all the interview tapes made for this oral history memoir of Lester Rowntree, Skee Hamann's one hundred page typescript life of Lester Rowntree, "Runaway," and Skee's annotated transcript of the letters she received from Lester, 1966-1978. 

THE LESTER ROWITTEE ARCHIVE AT THE CALIFORNIA ACADEMY
OF SCIENCE

Volunteer Archivist at the California Academy of Sciences, San Francisco

Levenson: Mrs. Campbell, it was very nice of you to let me come today to your home in Piedmont rather than to the California Academy of Sciences, to talk about Lester Rowntree. But, first of all, I'd like to ask exactly what it is you do at the Academy?

Campbell: Years ago, before I was married, I worked as a research associate at the American Geographical Society in New York. I loved the atmosphere; I loved having all sorts of books around and available. That was put in abeyance when I married. [Dr. James V. Campbell] We had a long, busy life together.

When our son was old enough to run around and handle his own affairs, I happened to go over to the California Academy of Sciences, into their new library, and I thought it was the most beautiful, peaceful place I'd ever seen. So I said, "My, I'd like to work here." Miss [Veronica] Sexton, the librarian, said, "We11, we'd love to have you, but there is no money." I said, "Well, could I volunteer?" "Yes." Then I flabbergasted her by suggesting I come over twice a week. She finally accepted. She knew I was interested in botany in addition to my natural science background, so she started me arranging Alice Eastwood's papers.

Alice Eastwood was head of the botany department at the Academy for many, many years and led a very interesting life. So I had a great time arranging that.

Levenson: About how long ago was that?

Campbell: That I went over there?

Levenson: Yes. 
Campbe11: I think it's almost fifteen years. But this Eastwood thing was lots of fun. I had gone over to The Bancroft [Library] and asked them how they arranged their collections. I had a good training on that. But the trouble was that Miss Eastwood's papers were in several boxes, and Miss Sexton kept finding a new box, which meant redoing the whole collection.

At that point, I sort of gave up on doing a formalized archival situation and went into this open-ended affair, which now is the type that we use at the Academy. So I can walk around in the stacks and slip pieces into various boxes without having to put each piece in an exact spot. This became necessary because, about two years after I came to the Academy, Miss Sexton retired and Mr. [Ray] Bryan became the librarian. He turned the staff loose on the top floor of the stacks, which was nothing but huge collections of books and papers given by people. We sorted books and papers for months.

So, all of a sudden, I had everybody's papers to handle, and it was pretty hectic for a couple of years, but we finally got the thing under control. As I say, this archive is not a formal set-up. Each one of those collections is open-ended and material comes in all the time. So, that is the best I could do with it.

First Meeting: Lester Rowntree Burning Her Papers

Levenson: How did you come to meet Lester Rowntree?

Campbell: I happened to be down at Carmel, and a niece of my husband's said, "I want to go up and say goodbye to Lester Rowntree." I said, "Oh, I'd love to drive you. I know her name and what she's done, but I've never met her."

We went up to see Lester, and Lester was burning her papers in her backyard.

Levenson: Why?

Campbe11: She said nobody would want them.

Levenson: Before we go on, would you tell me how it was that your niece met Lester Rowntree? I thought that was such a charming story when you told me at the Academy.

Campbell: All right. Shall I start right wi th that now? 
Levenson: Please.

Campbell: This was niece Nancy Hayes. She was a photographer, really professionally trained, and was out living in Berkeley with a friend who was a nurse. The two of them were having a perfectly wonderful time going all around California, and seeing everything and doing everything on very little cash.

They, went down to Carmel, because there was a Quakers' meeting being held. They had become quite interested in the Quaker welfare activities, so they thought they'd go down and see this. It was a very interesting evening, and they stayed to talk to the speaker till they were among the last people. At that point, this little woman came up to them and asked if they had a place to spend the night. They said no and she said, "Well, I have a house and if you would like to sleep on my balcony in your sleeping bags, why, that will be just fine." That was Lester Rowntree!

They got up to Lester's and it was a wonderful spot--the house is on a hill and overlooks the ocean. The view was terrific, and they had a perfectly marvelous time. There was a special rapport between our niece, Nancy, and Lester Rowntree. They became really very close friends. Nancy saw her about every three or four months all the time Nancy was here. Then when Nancy went back to continue her work in Chicago, she made a very strong point of seeing a good deal of Lester every time she visited out here.

Lester knew that I was, at least, properly introduced through her good friend, Nancy. Another tie was my husband's uncle, Douglas Houghton Campbe11, who was the first professor of botany at Stanford University. Douglas had only a passing acquaintance with Lester, but he was known, and if we were on that family tree, that also made things pretty good.

The first time I went tc see Lester, I didn't have very much time. But I was so shocked when Lester said that she was burning her papers that I asked whether she'd be willing to give them to the archives at the Academy. She had always used Alice Eastwood and $\mathrm{Mr}$. [John Thomas] Howell as her sources for the correct names when she felt she couldn't identify plants properly. She said, yes, she guessed so; she didn't know how much good they would be. But anyway, I had a tentative answer. I took that to Miss Sexton and Miss Sexton said, 'Why yes, she thought that the Rowntree papers would be a very appropriate addition to the Academy archive. For the next years, every time my husband and I went to Carmel, we came back with the station wagon loaded with boxes of Lester's papers.

Levenson: This started when, roughly? About ten years ago? 
Campbell: No, I should say it was more than that. I should say about twelve or thirteen.

Levenson: Why was she burning the papers?

Campbe11: Because she had felt that nobody wanted them.

Levenson: You mentioned a sljghtly different reason as well in the Academy.

Campbe11: I can't remember.

Levenson: You said that perhaps--if you don't want this on the tape, we can erase it. You said that she was burning them so that her daughterin-law wouldn't. [Harriette Rowntree]

Campbell: No, I think I meant that if they were left, the daughter-in-law would burn them. So Lester preferred to burn them herself. Now maybe there isn't much difference between what we're both saying. But, at that time, she did not feel that her daughter-in-law had any feeling or understanding of what Lester had done, which was incorrect, actually.

Description of the Collection: Valuable Seed Catalogues

Campbell: The house was loaded with cartons and cartons of papers. There were full file cabinets. You could hardly move in certain rooms because of the great amount of stuff. Now, I don't like to give the idea that Lester was a messy person. She had an excellent filing system and things were filed. For instance, one category would be by the names of the plants; another category would be the places she had been and collected from. Another one would be by the seasons. Then there were other special topics like water gardens, or roadside cuts, or wild gardens, rock gardens, shady gardens, sunny gardens; that's enough of those. [Chuckles] Anyway, she had these all in categories.

When she had used a piece of information that she had written down, she would take it out of that file and put it in one of the other files and write, "this used in such and such an article." So that she kept a very close tab on her material. Also, she had a fantastic collection of seed catalogues. She had made a big effort to get the English ones, because these English catalogues would show which of the American wild flowers had been brought over and were being bred in English nurseries. So they were quite valuable. 
Campbell: Also, she had collected catalogues from the Mediterranean areas and from South Africa, where the climates were the same as here. So those were very useful. I think I almost doubled the size of the Botany Department's seed catalogue collection when I brought Lester's material to them. They took that over; it is no longer in the archives.

Levenson: That's a remarkable contribution.

Campbell: It really was. Yet she was very depressed, I think, really, at the period when I met her. I think that after four or five years, relations became better between her and her family, and this mellowed her. Also her health became better. I think life has been much more pleasant the last seven or eight years for her.

We, at the Academy, have been very happy to have her papers. I'11 have to admit I threw away a great deal because her habit of making notes was not systematic in that she used any scrap of paper that was handy. One of her favorites were the bank slips, either bank deposit notes or the bank checks. I don't know where she got them. Here's the Bank of America savings account, you see. There were thousands and thousands and thousands of these things. often, there would be only one or two words on one.*

Part of the reason for these scribbles is becuase she kept a pad close to her when she drove. Her daughter-in-law told me later that she used to be scared to death to drive with Lester, because Lester drove with one hand and wrote notes on the plants she would see along the way with the other hand. [Laughter] As far as I know, this never ended in any particular accident.

But there were so many of these small notes. What I would try to do was find a larger sheet of paper that perhaps had consolidated some of these.

Then she had what she called "Helps." These were two adjectives usually, such as "stunningly effective" or "sourly drab." Unusual combinations of adjectives which she would use later to describe plants. There were so many of those, I decided I couldn't save all the sheets they were written on. So I copied them off and I had fourteen sides of a regular typewriter-sized paper full of these little helps that I found through her material.t Some of them were delightful. She was very good at saving English expressions and using them.

\footnotetext{
* See following page for examples.
} 

$5 a$

nor bie cist of Feb.

(3) - dicil

'y tizzonds

iffer

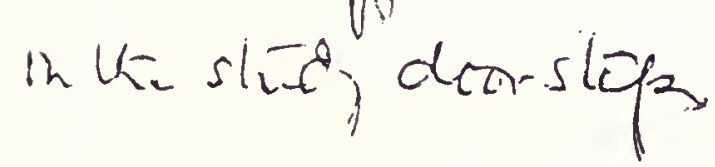

THE EARHK OF CARMEL

Carmblab.the.Sra, Galif,

PLEASE LIST EACH CHECK SEPARATELY

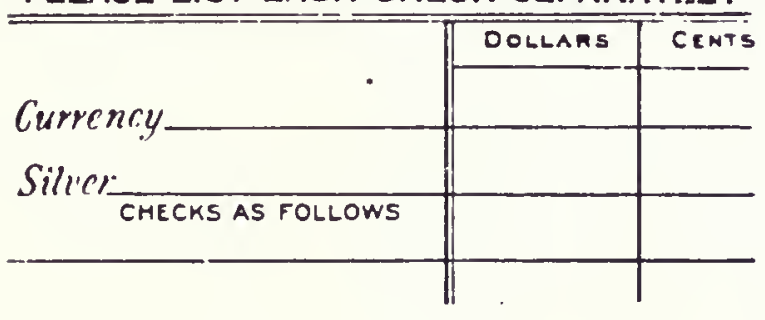

beinle

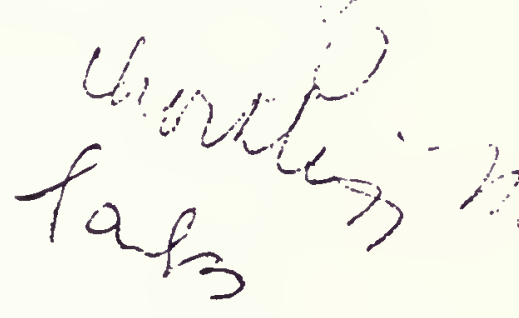

un

trithy

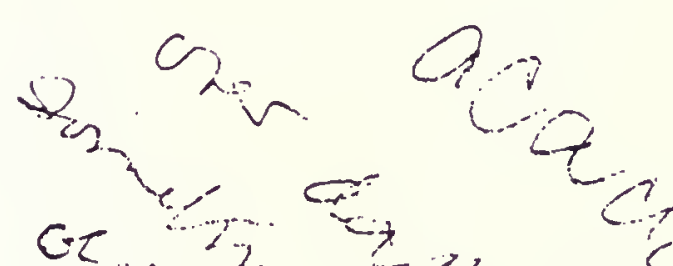

2 ${ }^{2}{ }^{2}$

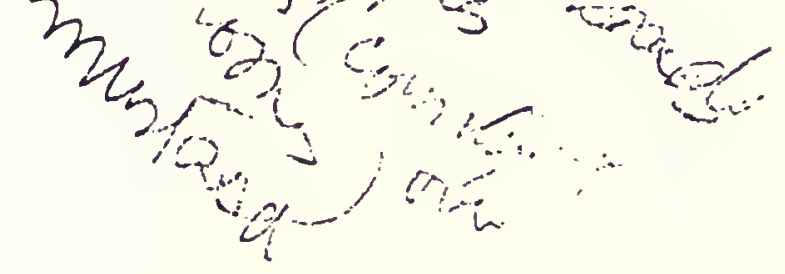

19

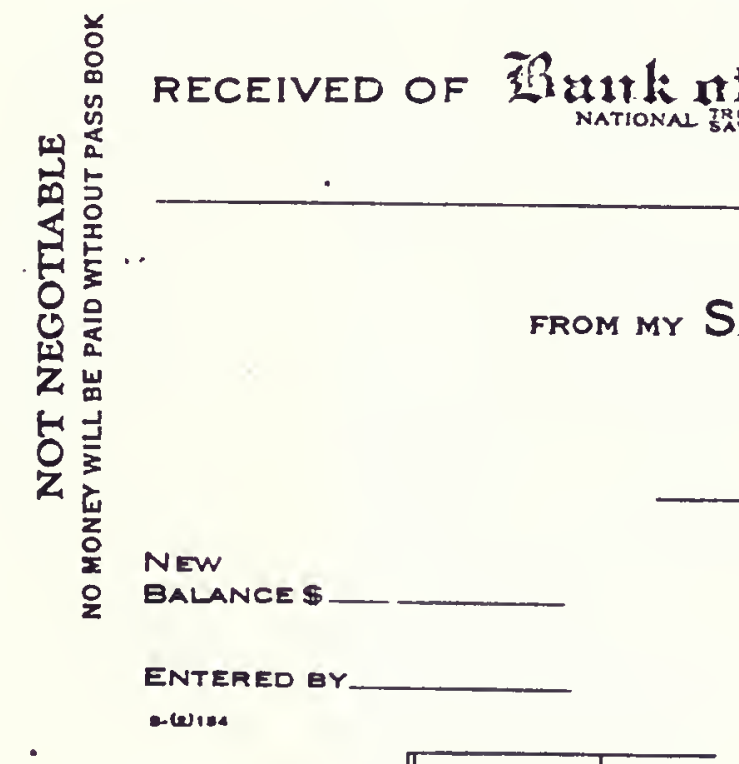

Dollars

$\$$ 
Campbell: One I found today. I was looking through some of her collecting expedition materials. She is describing a spot where, near which, there are some seeds that she wants to collect. She calls it a luncheon spot--not a picnic spot or a lunch spot, but luncheon-and written out three times in that scrawl. She had a particular feel and standard on how she was going to say things and I think her writing shows this very clearly, and it's one of the delightful things about reading her books even now. There is that Lester personality in them, quite decidedly.

I don't know whether I've given enough on her filing system. Do you think so?

Levenson: One of the things that I was so pleased to see was the card file on all her periodical writing.

Campbe].1: Yas, done by herself.

\section{A Note on Lester Rowntree's Background}

Campiell: Lester was born in England. The family had a large walled garden, I believe. They lived in the Lake District. The children all had their own particular garden, and Lester loved hers and did all sorts of crazy things in it. But it was hers and she could do what she wanted with it. She remembered one time she was simply furious because the coachman had told her that she could plant her bulbs upside down because that way, they would go to China and then turn around and come back. She thought this was a wonderful experiment and then was simply furious when they never came up at all. So that is one of her bitter memories.

But the country was beautiful. She escaped from her home as much as she could to get out into the countryside. I think the family did encourage picnics and going places, and Lester made the most of any opportunity that way. So she loved flowers right from the beginning.

The family moved to the United States, to Kansas. Just why Lester's father decided he wanted to be a farmer, I don't know, but he did. The well on the property had typhoid germs in it. Two of the children died, and I think a number of them were seriously ill with it. So that farm was given up and they moved to southern California, I think near Pasadena somewhere. I didn't bring those notes home with me; they're at the Academy. 
1. Edward Lester and family at Penrith, England, before leaving for Kansas, Apri1, 1889. Gertrude E1len Lester (Rowntree) front row center.

2. Lester's parents, Edward and Mary Hanna Ashby Lester in Los Angeles, c. 1895.

3. Lester Rowntree, teacher and schoolmates at Westtown (Quaker) school, Pottstown, Pennsylvania, 1900.

4. Lester Rowntree's graduation picture, 1902.

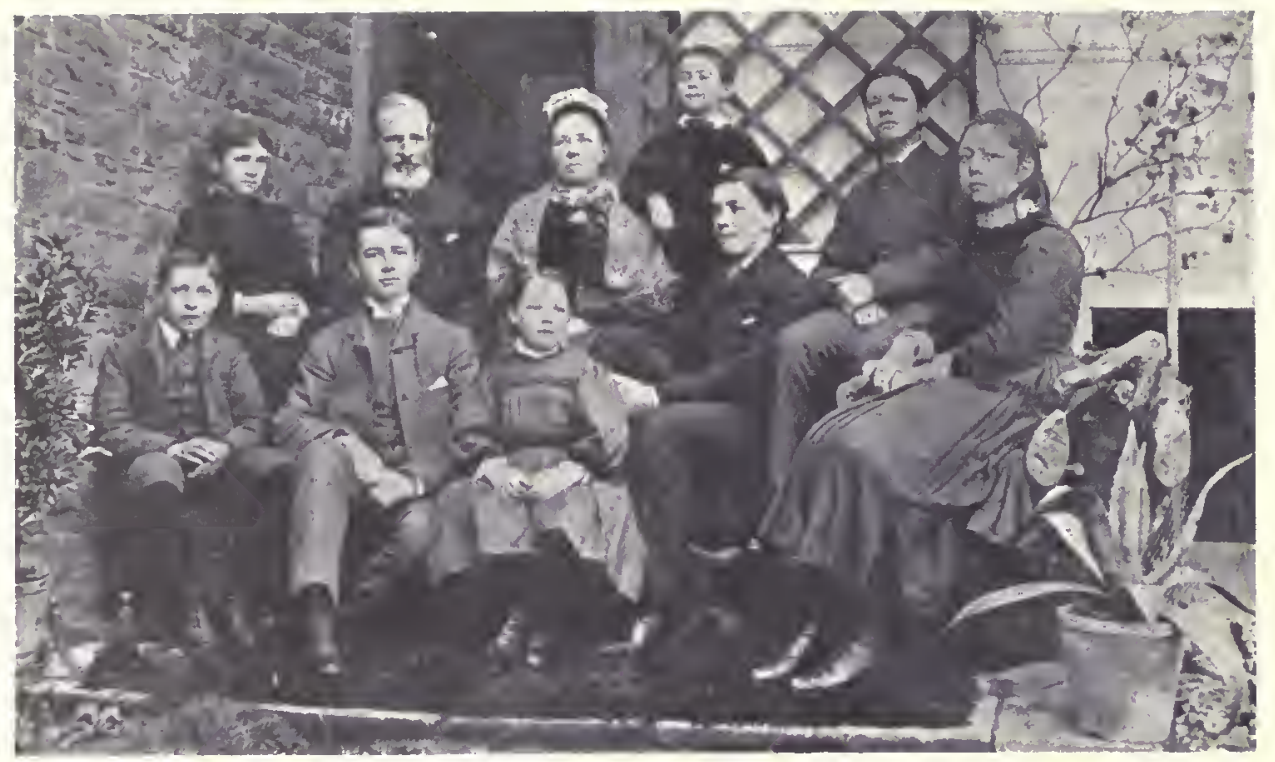

1.
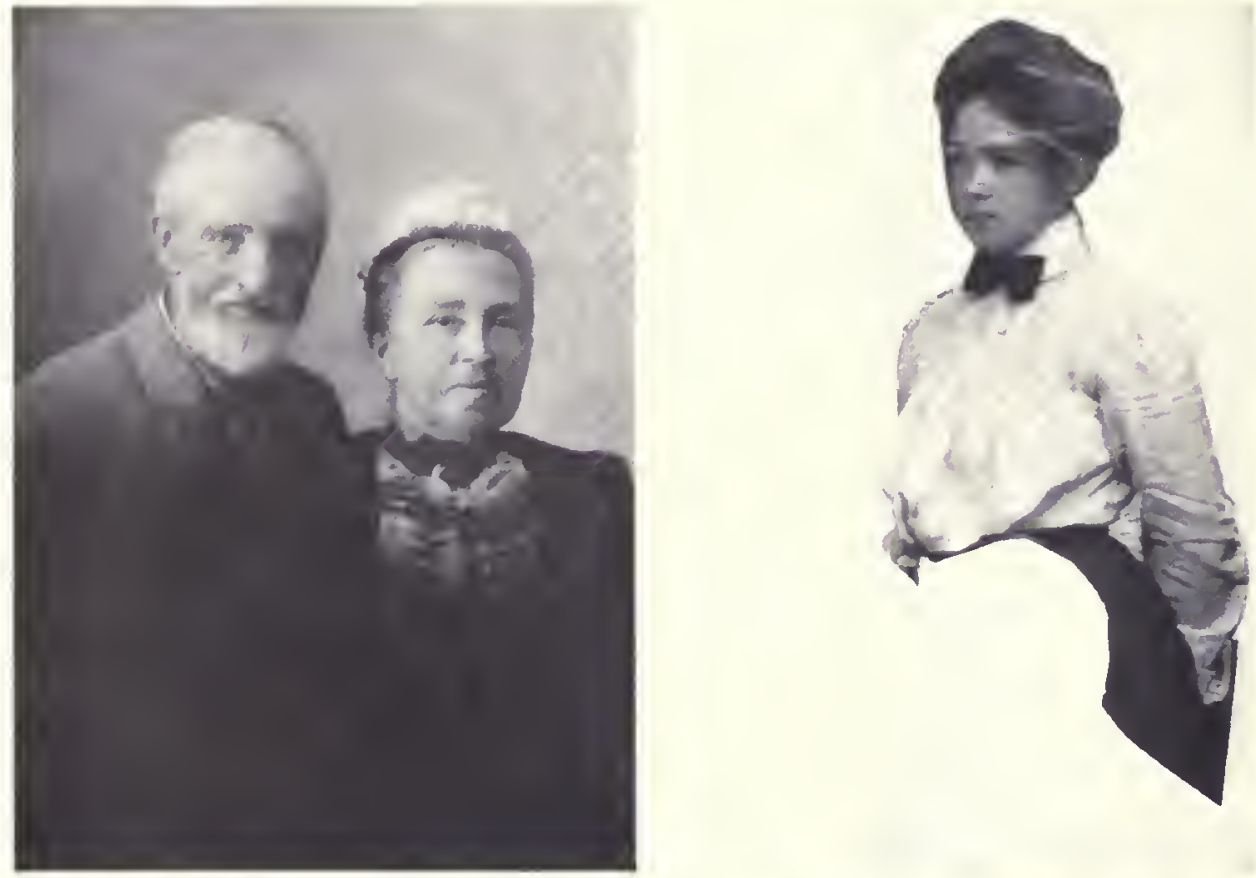

2.

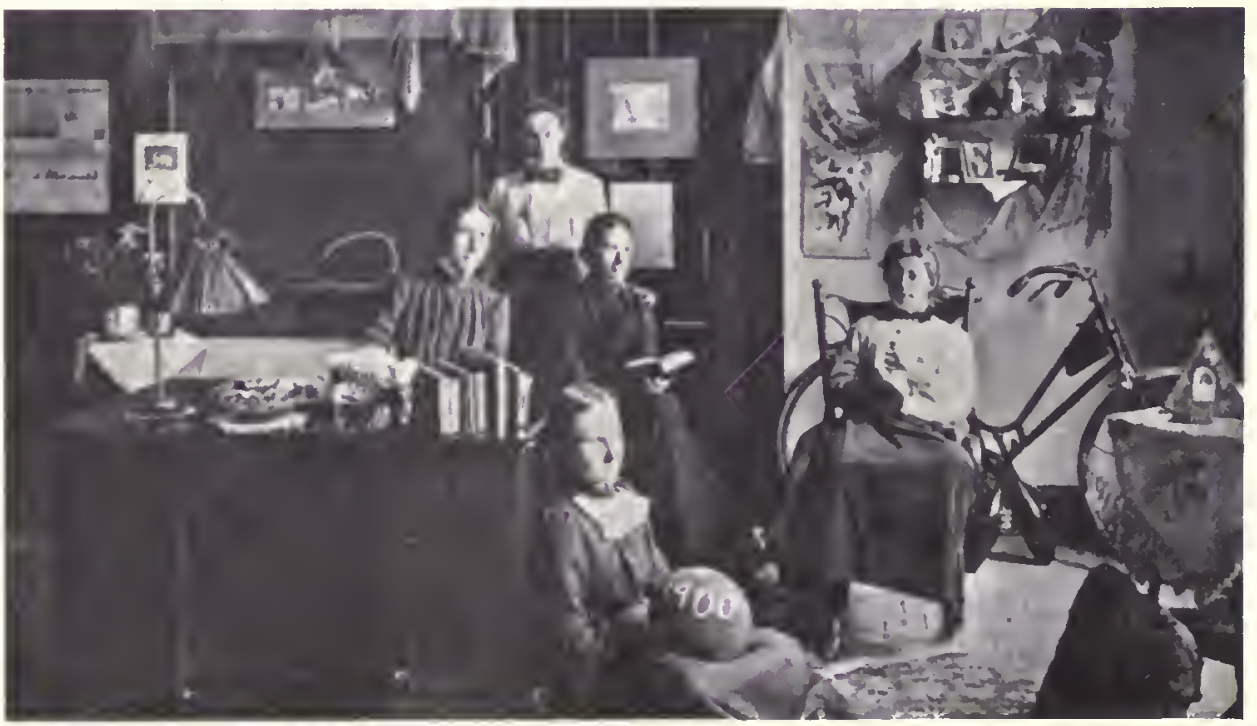




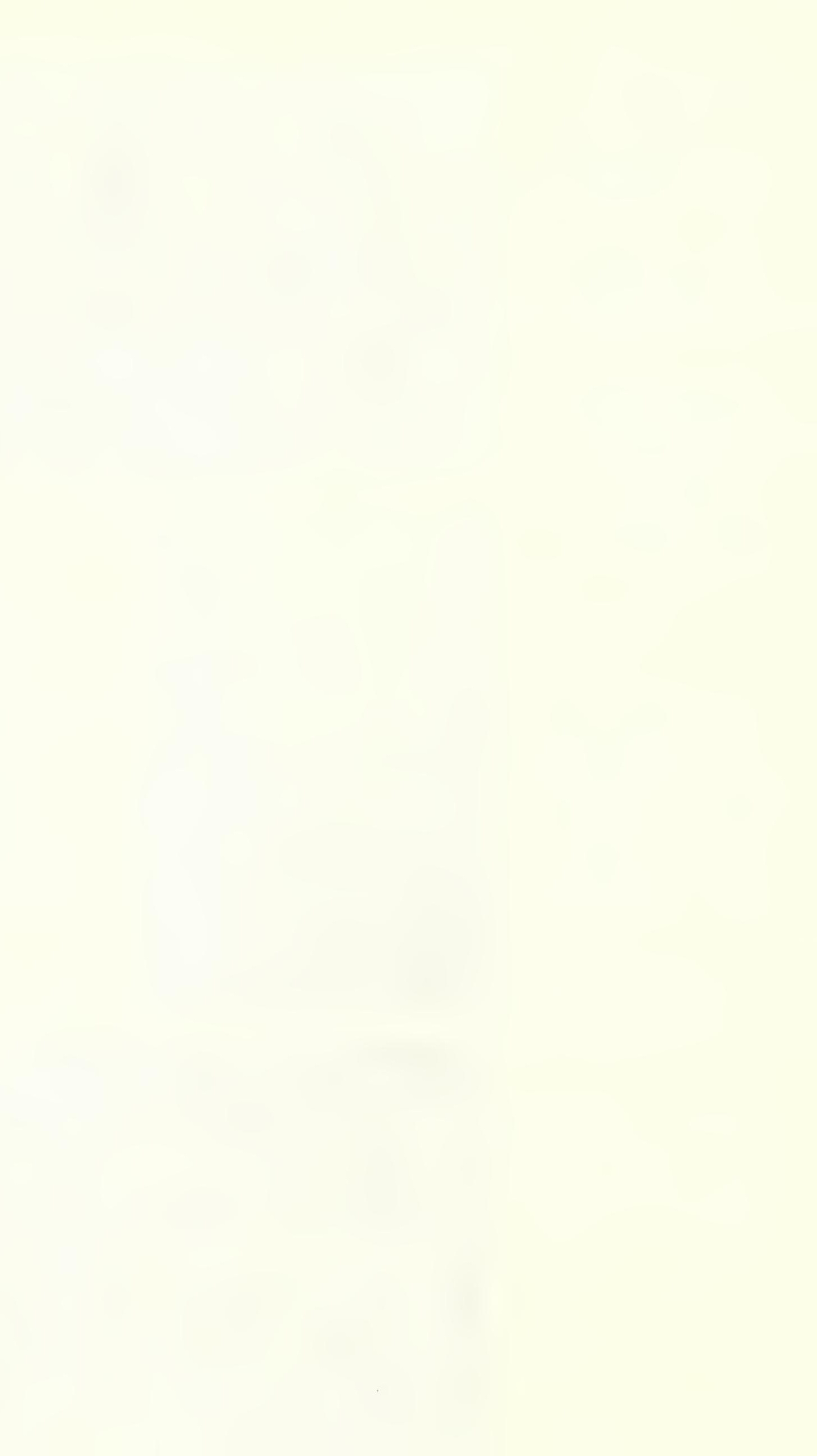

列

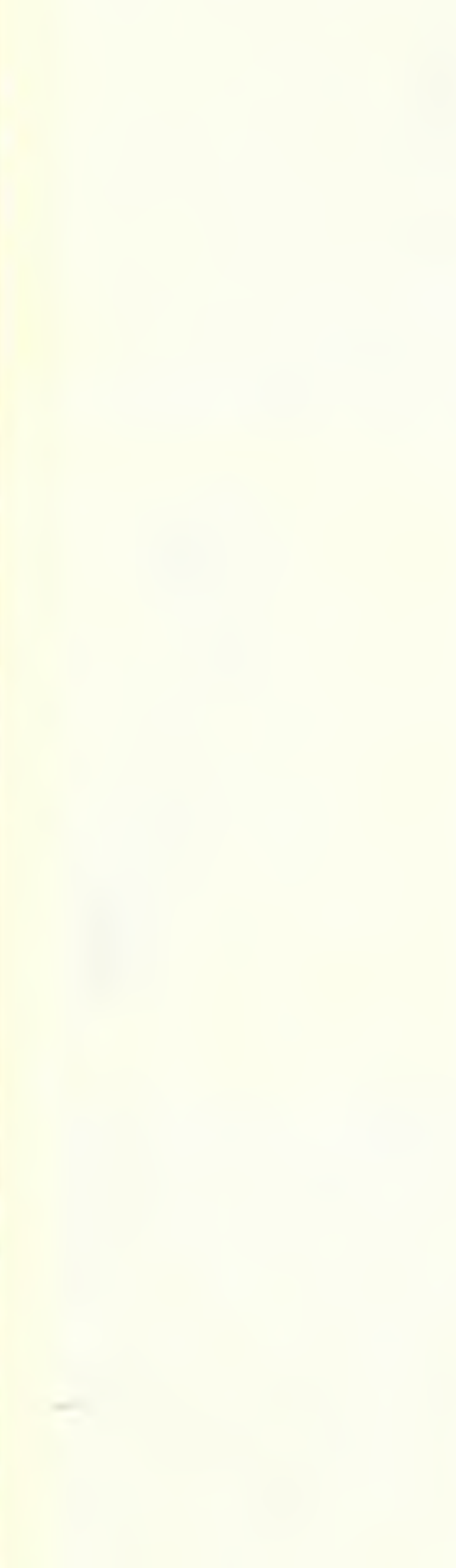


Campbell: There, again, everything grew beautifully and Lester had a marvelous time and got her first knowledge of the spring wild flowers in California, because in those days they carpeted the hills and the foothills around Los Angeles.

Then her steps led her East. She married Bernard Rowntree and they lived in New Jersey, and Cedric was born. Her home was called The Rowans, for the two rowan trees that stood on either side of the entrance gates.

I think Lester must, basically, have always been an extremely self-centered person. She was dynamic. She was used to getting her own way, no matter what. Often she was rather wrong-headed about this.

Levenson: Whose judgement is that? Yours or hers or other peoples?

Campbell: It is mine. This is looking at it from a distance.

When I first met her, she was very secretive about her background. She didn't even want to tell me where she was born, or what she had done in her youth, or her whole name even. There were a number of these things that she was just blocking out completely. She was having none of it.

Levenson: Can you account for that at all?

Campbe1l: No. Except I think it was basically this inner frustration. She was frustrated. She wanted--she had lots of energy. She wanted to go on doing the things she'd been used to doing.

Levenson: How old was she?

Campbell: Eighty-six, eighty-seven. And she was not able to do it. Physically, she had a lousy stomach. I think she had lots of energy, but her tummy got in her way. There were so many letters on natural foods and so many recipes on natural foods and things like that in her papers, that I feel she must have had a great deal of stomach discomfort.

Also, she wanted to be in the thick of things and she couldn't see well enough to do it. She got to the point the last few years, where she couldn't even drive herself down to Twentynine Palms for the winter. I think that the last time that she drove down, one of the family went and got her. Her grandsons were both in college at that time, and I think her grandsons went and got her. Then maybe the next time, they drove her down and back. 
Campbell: After that she could not drive. It's no wonder. Anybody who's driven that road up to her house knows it's really quite a mountain goat trail, and is hard to negotiate under the best of circumstances. And with poor eyes, I think it would be a dreadful thing to do.

So I think she was frustrated. She didn't feel too well. She felt life had come to an end but she wasn't able to die. I think even then she would have been happy if she had known that her life was going to be cut off. But there was no sign of it. Here she was, just sitting around, and sharing her house with her son and daughter-in-law. She didn't like it.

She, I think, always wanted to have a close relationship with her son, and introduce him to all the glories of nature, the pleasures that she'd had. Yet, like an English boy, he was sent oif to boarding schools at a very early age. This was extremely hard on him; he was a sensitive youngster, but off he went.

She sent him to Westtown, a Quaker school. Pottstown was the name of the town. Westtown/Pottstown. She had gone there; so she wanted him to go. Her Quaker background came out sometimes in very interesting ways. One of them was the close connection which she kept up with this school. Always. I found out when she went East the last time, she went to Westtown to see the place and go over her favorite haunts. She wanted Cedric to go there.

I feel there was a psychological jealousy of her daughter-inlaw. I've seen it in other women, when their sons have married and the daughter-in-law is never really accepted. Fortunately, I think this situation is now over.

When I first met Lester, she was very bitter about Harriette. Lester felt that Harriette was a cold, nasty, unfeeling person. But that is no longer true. It hasn't been true for the past five years. I think she has come around and has begun to realize that Cedric and Harriette have a very good married life. They have produced three fine children, and Harriette has been a saint to Lester, and I think Lester has really begun now to appreciate these facts.

You want me to tell the story about grandson Lester?

Levenson: Yes, please.

Campbell: Grandma was feeling very low and said, well, she really thought she ought to die shortly. And her grandson, Lester, said to her, "Grandma, you can't die." She said, "Why not?" He said, "Your 
Campbell: heart is too full of hate." She sald, "Who do I hate?" He said, "Harriette." Her jaw dropped and she said, "I didn't mean to." Now, if this is all true, maybe it was all so deeply subconscious, she didn't realize it. Anyway, from then on, she did make quite an effort to be friendly. I think that now she really appreciates Harriette very thoroughly. So that grandson Lester really did a good job.

Both the grandsons are fine people. Both are in geography. I have met them both and talked to them. They had no illusions about their grandmother. That she was a driving dominant person who thought and acted first on what she wanted. It's too bad, but I think this is true.

Levenson: Perhaps it's one of the reasons she accomplished so much.

Campbell: Right. Certainly, the family relations are excellent now. It's just as well she lived as long as she did, because if she had died eight years ago, there would have always been that bitterness about grandmother and the way she had treated their parents.

But now things are different. For instance, Lester married a German girl, Heldi, and Heidi was used to home deliverles. When she got pregnant and said she wanted to be delivered at home, they couldn't find any physician in the neighborhood where they were living who would do that. So Lester, Grandma Lester, marched down to a doctor that she knew in Carmel and asked him if he would do a delivery at home, and he said yes. So Heidi came down and lived with Lester, Grandma Lester, and the first great-grandchild was born in Lester's bed. This, I think, brought the family generations closer together.

Levenson: Could we go back in history a little ways to Lester Rowntree's marriage?

Campbe1l: The trouble began when she had what may have been a uterine cyst. It was diagnosed as cancer; it was removed. But she was very unhappy, and of course at that period, if the thing was diagnosed as cancer, you were dead in a couple of years. So she announced that if she was going to die, she was going to die in California. She was not going to die in New Jersey. She hated it. So, she upheaved her husband from his good business in New York City and the family moved to southern California.

How long they were there, I don't remember. But eventually, they moved to Carmel. Mrs. Rowntree had a brother [Francis E. Lester] in Carmel who was growing old roses. He was known all over the world for his culture of roses that were historically important. He put out one of the most beautiful nursery catalogues that $I$ ever saw. He had died before I really was in on Lester's history. Anyway, there had been a brother there. 
Campbe11: It was very shortly after--it couldn't have been too long, although they had been together in Carmel long enough to build a big house in the Highlands and to pretty well landscape the place. It was that place that Lester got when the divorce came. Then she built her present house above it in 1932. I really don't know what her husband got, if anything.

In her seed business, she used the name Lester because she wanted it to sound like a man and professional. She was originally Gertrude Ellen Lester. She gloated everytime somebody addressed her as "dear sir" in a letter. She had that little thing. I guess the divorce was rather nasty. I never have been told the details by anybody.

She had an arrangement with a Miss [Lila] Clevenger, who lived with her and acted as a secretary, someone to forward mail, someone to take care of the youngster when he was there. She was a typist and I think she typed all of Lester's early papers.

There was a breakup in the end which was very unfortunate. I don't think Miss Clevenger was as much to blame as Lester thought she was. This may have been part of a hangover of Lester's poor mental state. But that was long before my time. I have no definite knowledge of that.

After Miss Clevenger, Lester went into partnership for a time with Mr. [E.K.] Balls, but she said he turned out to be a complete and utter villain. Anyway, there was a long and nasty set-to on property rights. Evidently, Balls had seen to it that Lester signed the proper papers, giving him the property, so that she had no legal comeback when she found out what had happened.

I think Harriette's feeling was that Lester had an--"oh, don't bother me about that, don't bother me about that, that's uninteresting"--kind of an attitude and did not take any pains to see what was happening.

Levenson: What a shame!

Campbe11: Yes, it's too bad, but it was strictly Lester's fault, it really was.

Levenson: So punctilious with her botanical labeling and so sloppy--

Campbe11: Yes, yes. You know, she was a redhead. I've often thought that might have had something--I don't know, but I think redheads and temperament often go together. So, I think that maybe she came by some of it through her genes as well as through the way she handled herself. 


\section{The Quaker Connection}

Campbe11: The Quaker religion is there in the background but I don't know enough about it to know how much. I do know that Lester paid an annual subscription to the Quaker fund--what do they call it?

Levenson: The American Friends Service Committee?

Campbell: Yes, the Friends Service Committee.

I found receipts for contributions to that, year after year after year. So this, considering her extremely limited income, I think shows that she must have had some real feeling.

I don't even know whether Lester ever went regularly to the Friends' meeting house. There must be a large group of Quakers in the Monterey-Carmel area, because it was at a Friends' meeting, a Service Committee meeting, where my niece met Lester.

Lester looked up Quakers all through the East on her trip, but I was left with the idea that this was because they could give her bed and board and move her on to others, rather than because of the religious feeling. I'm sorry, I did feel that way. But also, she was independent. I should say this, having made that last remark. She did arrange her car so that she could sleep in it. This horrified many of the people that she visited and they insisted on giving her a bed. But she was quite capable of sleeping in her car and very happy doing it, so she was not dependent on Quakers passing her from one to the other. I wouldn't want to give that impression, but she used the connection when she could.

\section{Seed Collecting}

Campbe11: During the early period of her collecting, she had to go out during the spring and early summer to locate good stands of flowers; then in the fall or late sumer, she would go out to these stands and collect the seeds. She was always very, very careful to leave enough seed to reseed the area. She's made quite a strong pitch on this particular thing because there were some seed collectors and native bulb collectors who didn't do this. They just went out into the area and took everything there was, and decimated the wild plant situation. Lester was most ethical in her dealings with the native plants. 
Levenson: Did she ever tell you how she arrived at this practice which is now, of course, regarded to some degree as the discovery of the younger generation? [Laughter]

Campbell: Much as it may surprise the young people of today, conservation of the environment was a well-known topic years and years ago. Remember Gifford Pinchot and Teddy Roosevelt.

Lester was well-read and certainly knew about conservation problems. With her love for the outdoors, she would not want to destroy any of it. Furthermore, if she was to continue to have a native plant seed business, it was necessary for her to leave seeds enough for the next year's crop.

Her gardens in New Jersey and also in Carmel Highlands were on the edge of undeveloped land. She had had experience in gathering native plant seed before she actually went into the business.

The [native plant seed] business, I think, came out of two things. One was that after the divorce [1932], she needed to support herself. Also, she was in very poor mental and physical condition. She felt she was going to die if she didn't get out into the wilds. She has always claimed to me that her excellent health was the result of getting out into the wilds and collecting out there.

I did find a few lists of the photographs that she had made. Her standards of photography were very high, but I don't think she was a particularly mechanical minded person. I think the camera drove her wild. But she persevered until she got the picture she wanted.

Levenson: This was something I was going to ask you about because Harriette, her daughter-in-law, also commented on Lester's aversion to mechanical things.

Campbe11: Yes.

Levenson: And yet Lester, who is going to be a hundred next year, drove a car on all sorts of byways and probably on a great many areas where there were really no roads. She took her camera out into the wilds. And she appears to have managed to run both these mechanical things very successfully.

Campbell: Only because she had to. Wherever she could get out of it, I'm sure she did. But I was interested in--I have a list, it's called 
Campe11: "Packing," and it's what she took with her.* There are several things in there that ceal: with the car. Ine car was quite a sight in those cays because she took out half of the front seat and all the bacik seat, and simpl: filled it to the roof alnostwith her eçuiptent. She reeded supplies and she was ofien gone iso or three worths.

Lerenson: lot nine uogths, as she indicates in her books?

Cazpol1: I :-sulc coubs it.

Le:enson: I wondered about that.

Capbe11: I thish she was is and out. But she would be gone three or four zonths, surely, to get way up porth and then pake her siag dow. In that list, there are several things that are needed for the care and leedizg of a car. [Laughter]

In jo:anical collecting, you have to have so man: nerspapers. They are quite a problea. It she was going to be gone three lonths, she would hare stacis of zerspapers wth plants in thet. I don't know if you know how a plant press is arranged?

Levenson: I've see: the=.

Capbell: what a botanist does when he goes into the field is to take newspapers. Ine zizst sheet, folded once, becones the first hove of the plant that he picks, Uswally, with a botarist, this includes the root as rell. This is laid inside; then on the newspaper soleshere, you scribble where you got it, the date, and other loca:ion things like in shade, in Full sun, or on a grazite slope. Then you get a pile of these, and you have two stiff, heavy boarcs or the outsices that are held together with straps. You car exert pressure on these straps. Inis flatiens all these saples and keeps the close to the absorbent paper so they' 11 dry. But also, about every two or three cays, you heve to take the out, see how they're drying, and wasbe expose the= to the ail or sun a few days to hasten the drying because they can aildew.

You have to know, particularly, what to collect. The onion fanily, for exazple--it's just lots of fun to collect the roots. but you have to have the scales. The way you identify the ozions is by the root scales.

So it took a lot oj equiprent. Then she would occesionally want to take soue plants hove with her. For these, she carried a lot of ezpty cans.

*See following page. 


\section{PACKING}

waterproof coat woolen hose, 4 pairs

all glasses

flask

face cream

long pants

gloves

shoe laces

nail file

00 paper

mosquito netting, all

extra shoe supports

shoes

nipsters

scissors

sewing things

Pyrol

camera things

pills

plenty sweaters

carboil, etc.

matches

washcloth

two towels

toothbrush, brush \& comb

soap

oiled cloth, etc from blue bag

2 pillows

tripod, etc rubber ropes for supports

safties

Jepson

rubber bands

pencil,

knife

lots of paper

newspapers

clips

gum ointment

2 prs. woolen night hose

string

gue

seed bags

BURRO TRIP

Hammer

nails

food

pans

shove1

hatchet

canvas

compass

hay

berets

lemons

soap

bucket raisins

cocoa

bacon \& tin to put grease in

sewing stuff

adhesive, etc

onions

canned milk

al1 glasses 
Levenson: Living plants in this case?

Campbe11: Yes. Particularly the young firs or shrubs. So, she would come back with her car loaded with those as well. She had an ongoing job taking care of both drying and living specimens while she was collecting.

Often she parked the car and went into the roadless wilderness for days at a time. Her pack--at that time--there were no sleeping bags. They were bed rolls. As far as I know, she never really used a sleeping bag. She talks about sterno, cans of sterno, so she did have that kind of cooking with her. But she very seldom would make a fire. It was too dangerous and she'd have the fire watchers down on her if she did.

She lived largely on nuts and chocolate, and prunes and raisins--things that were easy to carry and very nourishing. Then, of course, if there were wild fruits, why she went into those, too.

Lester Rowntree's Contributions as Horticulturalist and Author

Campbe11: She always had her hands in the dirt, excuse me, the soil. [Laughter]

She was always interested in growing plants as well as in collecting. She never went strictly native plant. This, I think, shows in her own garden. She wrote quite a bit about her garden. I have piles of notes which are arranged by date. Each one is confined to a particular month of the year and tells what she thought and did about her garden at that time. You'11 find there are about as many of the horticultural-type flowers as there are the native ones.

Levenson: What you might call introduced.

Campbe11: Yes. What's the other word?

Levenson: Not ornamental, is it?

Campbe11: No, that isn't it. Exotic! Which means they came from somewhere else. She often wrote on exotics that she grew in her garden. For instance, the most gorgeous yellow flax from England. It had escaped all over her garden. The last few years--even eight or ten years ago--Lester didn't have the time or the energy to weed and formalize her garden at all. It was just sort of a general overview of things she had grown, and all through it was this gorgeous yellow flax. I've been down there when it was just a riot of color. She would take English flowers, grow them, and determine whether they would be satisfactory in California gardens. 
Campbe11: As she grew older, writing occupied more and more of her time. She did do quite a bit of talking to clubs. She had some color slides; the family are keeping those for the moment.

Levenson: It's hard to summarize the career of somebody who's going to be a hundred next year and has been engaged with plants for more than three quarters of a century. But if you can break it up at all into subjects, I'd like to ask what your view is of Lester's contributions. Let's start, say, with botany.

Campbell: Actually, as botany is known as a profession, she was not a botanist. She was self-taught completely. She used [W.L.] Jepson, which was her bible. Jepson's A Manual of the Flowering Plants of California is a wonderful source because it is profusely illustrated, and this really helps an amateur. She quite often felt insecure in her decisions about what a plant was, and then asked Miss Eastwood and Mr. Howell to identify it.

The botany department is always happy to do this because they keep the specimen that is sent in and this adds to their collection as well as giving Lester the correct name, so it's a two-way deal. I don't think she did much on hybridizing.*

Her great contribution, actually, in a botanical line, is her propagation of the native plants. Collecting the seeds, planting them, and then studying their needs through the year as to soil and temperatures and exposures, and then deciding that this is something that would work in the New England area, or this could work perhaps in the southern section of the country, or the Midwest could handle this. She knew her climates very well throughout the United States and would slant her writings to one of these particular areas. When she wrote about a plant, she always described these necessary adjuncts, and in that, she was unique. That is why her two books are still so valuable--they really should be reprinted.t

* Lester Rowntree did work for a while hybridizing gazanias and mimulus (diplaeus). See "Plantsmen in Profile, XI: Lester Rowntree" by Natalie G. O'Connor, in Baileya, Vol. II, June, 1963, No. 2, p. 53.

+Hardy Californians MacMillan, New York, 1936

Flowering Shrubs of California, Stanford University Press, 1939, 1946 
Campbe11: In talking to Gerda Isenberg of the Buena Vista Nursery the other day, I mentioned Lester Rowntree and she said, "When are they going to reprint those two books? They're invaluable." She said you could hardly find them anywhere. They evidently were not printed in very large editions, and it takes years for one of them to show up in a used book sale. She said, "We've just got to have those books."

There is a company that I think may reprint them, but of course, that'Il be a while off.* These books are just as good as ever. Thorough, sound information on the requirement of each plant.

Levenson: On this question of the suitability of California natives for other climates, I've been interested in this for a long time. My English sister-in-law is a keen gardener and one of her proudest possessions, on Salisbury Plain, on that chalk soil, is a measly little ceanothus, which out here, would be growing like a huge umbrella.

When you consider our California climate, which is loosely speaking, six months dry and six months wet, how did Lester establish which plants would do well in, say, a climate like the Northwest here, where they have similar conditions to England, or the East Coast or Midwest of this country? Did she have other people experimenting?

Campbe11: No. For instance, on her collecting trips, she always stopped at nurseries and botanical gardens. She brought back boxes of notes from these places. And she had close connections with, say the botanical garden in Seattle; the one in Portland. Then, of course, we have some excellent nurseries in southern California. So, she was doing a lot of checking with them. She always carried with her a piece of paper and folded it in half and then in quarters [gesturing the folds], so it was a little thing she could hold in her hand. As she went around the beds in the nursery, she could scribble on this.

That was where she got much of her information. Say, this godetia did beautifully in southern California. Then, in the northern part of California, she would pick up cuttings and seeds that grew in the rainier parts of the area, or higher, where they would get more rain. Those were the ones that she would recommend for the Northwest.

*Both books are to be reprinted in 1979 by Peregrine Smith, Santa Barbara. 
Campbell: She corresponded a good deal with nurseries throughout the country. She did make several trips--one very long one in which she went east across the south and then north, in and out of the Piedmont and the Appalachians and all the way up to Maine; then down and across Ohio, Indiana, Illinois, and, I think, Iowa. Pretty directly across coming home, which left out a few states. She had had plans to go back and fill in on those states, but World War II interrupted those plans. She never went back again.

She never would really write about a plant for a particular area until she was sure that it would be successful there. I think you'11 find when you go through some of her printed articles, that she will take up a plant and describe it in detail, and say how nice it is. Then in the end, she' 11 say this will do very well here and here and here, but you people in this climate better not try it. She was very meticulous about this. People depended on her for that kind of information.

She wrote for national horticultural magazines as much as she did for the California ones. We had California Gardens, the Santa Barbara Garden Magazine. There were quite a number of good Iittle California garden magazines, and she would send short articles to them. but the kind of writing she enjoyed most was more discursive when she was writing a long article. Those went mostly into national publications.

She was quite active, for instance, with rock garden societies. She always took the English rock garden magazine and also the American one, and contributed to both of them. She always kept up with what the English horticulturists were doing, including the Royal Horticultural Society. If she was going to England, she always tried to get there at the time of the flower shows.

Don't forget to try to look over that red, bound diary of hers for her English trip because you will enjoy it so much. It was after World War II [1951], and she is seeing the damage done to the great gardens by the troubles of the war, the lack of gardeners, and the generally run-down condition of many of the very fine gardens. I think you'd be really quite interested in that. She bled for them.

Levenson: Oh yes.

Campbe11: California natives are very fussy; they don't transplant well. So the seeds are important. She would try to see that they were planted in the proper place. All that material would be in her seed catalogue and also in her articles. 
Campbel1: Now, on her writing, I don't know whether I've emphasized this enough, because I feel this was one of her greatest contributions. It was through her writing that she pushed conservation of native plants and the growing of native plants. So, basic to all of that was her writing. She did talk a lot to garden clubs and things like that, but I really feel that her writing was the most important of all the things that she did. I hope that gives it credit enough.

Conservation

Campbell: Then she had several hates, one of which was the way the highways just plowed through lovely hills and slopes and left these bare, rocky, or dirt slopes, places with no attraction at all. One of her big urges, particularly when she talked to women's clubs, was to get them to gather seed and take it out and sprinkle it on these bare spots. She did a list for the California State Garden Club on the proper kinds of natives to use in different locations. There's a copy of that in the archives.

The garden clubs were very aware of her crusading for, first, to save the wild flowers and, second, to cover up some of these nasty spots where the wild flowers had been destroyed, by bringing them back in. I think that was very important to her.

While she was still actively involved with the native plant sced business, she had an accident--a slipped retina in one eye. She was out in the field and, as usual, she never let anything like herself bother the business of collecting. If that was to be done, she went ahead and did it. So, it was three or four days before she got to a doctor and discovered what this trouble was. She never has had good eyesight since. Whether there was also a slipped retina in the other eye, I'm not sure. But her eyesight was very poor. It was very difficult for her to get into an unknown country because she couldn't see too well.

Levenson: How long ago was this?

Campbe11: That I don't know.

Levenson: Was it when she was about 78 ? Or even longer ago? I knew she had an injury when a branch struck her eyes. 
Campel1: That may have been it.

Levenson: We can check on that.

Campbe11: That will certainly have to be checked because I don't have too much on--I'm poor on timing anyway, and when it comes to other people's time, I'm extremely poor. Anyway, she found she was really going to have to drop out of collecting seeds, and it wasn't paying too awfully well. So she did go more into writing.

\section{Garden Landscaper}

Campbell: After her eyesight deteriorated and she couldn't make her big collecting trips anymore, she set up as a landscape--I hate to say the word architect, because she wasn't; she was a landscaper. She did four or five gardens, mostly in either Santa Barbara or farther south.

Before highways were so good and cars were so speedy, Santa Maria was the halfway spot between the Bay Area and Los Angeles. Everybody stopped at Santa Maria because the inn there was a perfectly delightful place and the food was good. Mr. [John] McCoy was the proprietor, and he became very much interested in Lester.

Lester was interested in him because he had a tremendous garden. In the dining room there were these large windows [gesturing] and every window had an enormous floral set piece. These would be gladiolas, iris, large, showy flowers. Every table had a centerpiece on it. Every room had flowers in it. I think there were several people who spent all their time arranging flowers.

Lester had known Mr. McCoy very well. He decided--he knew she was a little hard up--that he needed a rock garden. She did him a rock garden and it was a very successful one. I think one of the best bits that she ever did. She had a perfectly grand time doing that. Much of Mr. McCoy's note paper contributed to her notes on various things. I found them all over.

Anyway, she did that rock garden and then some other gardens down south. One of them, and again, I don't remember her name, [Josephine Jackson] became a very good friend of Lester's. Eventually she bought a place near Twentynine Palms. Lester came down and spent most of the winter with her for a number of years, which was awfully nice for Lester, because Lester was interested in writing a book on desert areas and was going to do it as sort of a travelogue. 



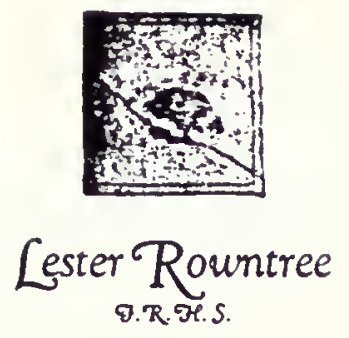

LANDSCAPE ARCHITECT

Carmel-by-the-Sea

California

\section{Rester Rowntree carmel. California} MAKER OF GARDENS

which express the owner's personal tastes

and carry them out with beautiful and unusual plants, exotic or rative.

"The right flower for the right place"

Unusual plants for Rock Gardens Wild Flower and Rare Plant Experts Authoritative Advice on Native Plantings

\section{LESTER ROWNTREE \& CO.}

Carmel, California 
Campbell: You went to one place and then you took the road this way and on the left you would see, and on the right. As Lester was working hard on this project, it was very nice to have a friend and a nice place to stay. This friendship continued as long as Mrs. Jackson lived.

I don't think that her landscaping really provided much income. She may have destroyed the material; my only way of knowing was what I saw, and there was very little among her papers that dealt with that side of it.

Anecdotes and Tales: Lady Byng, Jepson, James West, and Others

Levenson: You told me some wonderful stories when I was over at the Academy. About Lady Byng--I wonder if Lester wasn't some sort of snob?

Campbell: I think she was. It was a funny kind of snobbishness, but it was there. All her stories are about rather important people, her better stories, the ones that she tells regularly. I hope you'll be able to get her to tell one of these. It would be interesting against my memory of it.*

Lady Byng, I guess, had been always very much interested in horticulture and had met Lester when Lester was over on that trip after the war.

Levenson: To England.

Campbe11: Yes. And so when Lady Byng decided she wanted to come and see the gardens and everything in Canada and the United States, she wrote Lester and said she would like to stay with Lester and exerpience Lester's form of living. Lester said, "All right. I am very happy to take you on a seed collecting trip. But you've got to do it my way. You will have to have a bedroll and sleep on the ground under the stars, and you'1l have to live on what we can carry in our pockets" and so forth. Well, Lady Byng accepted.

Lester went ahead and made the plans and when Lady Byng arrived, she arrived with a chauffeur-driven car! And it was full of goodies. I do hope you get Lester to tell this, because I'm not

* See Lester Rowntree's version from Rowan Rowntree's interview notes, Appendix II and Lady Byng's version, Append1x III. 
Campbell: sure whether the chauffeur followed them over these roads or not, or whether Lady Byng did actually transfer to Lester's car. But anyway, Lester gave her as rough a time as she could on a short trip, just to let her know what the early collectors and Lester went through in order to provide all these seeds that the English were using in their gardens.

I think Lester introduced her to some of the local yokels and gave her a really good experience. I believe that Lady Byng came out with flying colors and never wept or drew the line at anything and that Lester developed a sneaking admiration for her at the end, very much.

Levenson: Was it on the Byng trip that Lester finally met Jepson? Or was that another occasion?

Campbe11: I can't remember.

Levenson: Would you tell me about Lester meeting Mr. Jepson, who was supposedly a misogynist or at least a woman hater?

Campbe11: We11, he was, in a way, but on the other hand, two or three of the women in the botany department at Cal [University of California] were very good friends of his, and one of them was left as executor of his estate. So I think that maybe that's built up a little.

Now, Jepson did not like Alice Eastwood. There was a great deal of rivalry between the two, and Alice couldn't stand Jepson. They did nasty things to each other [chuckle]. This is by the way. Alice wrote a very nice article on the plants that are found in the dooryards and the cobblestoned streets in San Francisco, and the great variety of such plants. How they manage in this very rough environment. I think she called it Natives of the Cobble Stones of San Francisco.

At that point, Erythea--Jepson was the editor--was the best botanical magazine on the West Coast. So she sent it to him. He accepted it, but he changed the title. This infuriated her, so years later, when she had her own Leaflets of Western Botany, she reprinted it with the proper title.

Levenson: Can you tell me about the occasion, as far as I know the only occasion, when Lester met Mr. Jepson?

Campbe11: Yes. Lester had thoroughly enjoyed her few letters--I found very few letters--from Jepson, but he thought she was a man and every letter began "dear sir." She had enjoyed this very much and I think she really didn't want to spoil it. 
Campbe11: That was the reason why, when she went up [to Berkeley] and knew there was to be a reception--it was [T. Harper] Goodspeed, I believe, that engineered this. And I believe it was the time of Lady Byng's visit, because she had told Goodspeed that Lady Byng wanted to meet him. Goodspeed was so flattered that he set up this reception. Whether or not he had told Lester of this, she did not have a skirt. Lady Byng did have one with her. But Lady Byng insisted that Lester have a skirt if she was going to this reception.

Lester had to borrow a skirt from somebody and it fitted pretty well, but it wasn't Lester's type, and she appeared at the reception. Among the people there was Jepson. He was flabbergasted when he found Lester was a lady and in a skirt! And it sort of threw him, but he was game and they got into a very interesting conversation. They drew off into a corner and, I believe, carried on a very animated and friendly chat for ten or fifteen minutes. So she always felt he was a friend. I think she admired the way he took the shock [laughter] when she appeared in a skirt because that's not what he had expected.

I really don't think he hated women. There were a few that he was bothered with. He was not patient with anybody, and if you bothered him too much--he could be as nasty to Mr. Howell, who was a graduate student under him, as he could be to any female.

But Lester tells a good story and this is what you need to make a good story.

Levenson: [Laughs] Right.

Campbel1: This botanical garden story of James West--he was German. It became known, among his intimates, that he was from a high-titled family in Germany, I believe Prussia, and had had to flee Germany. I think this was well before World War II. I don't believe it was the Nazis, I think it was something else that caused his departure from Germany. He changed his name to James West.

He went in for rock gardening and he designed and planted many very fine rock gardens in the Bay Area and down south. He did the Livermore Garden; he did a Hearst garden. All the best families had rock gardens done by James West. He was a very brilliant horticulturist. As such, he was a very good friend of Lester's. They got along beautifully together.

On this particular night, she had come down from the north. She met West and, I believe, James Roof for supper. They got yacking as usual and it became too late for her to drive all the 
Campbell: way down to Carmel. So they said, "Wel'1l have to find a spot for you." She said, "I can just throw my sleeping bag on a piece of lawn anywhere or I'll sleep in the car." They said, "We have a good idea."

West had a key to the [University] Botanical Garden. So they went up there. He unlocked the garden gates, Lester drove through, they parked the car out of sight, and then they went out and locked the gates on her. The next morning, they got back in time, and what's more, she even had had a bath in Strawberry Creek by the time they got there. So she had a very nice, quiet, restful sleep, and departed before the gardeners came in in the morning.

She did see a great deal of James West, and I believe he was the one who came and stayed too long at her house. She said, "We11, you can't drive back tonight." "No," he said, "I'll take my sleeping bag and throw it any old place." So she said, "Well, here's this or that, but if you go in this fenced enclosure, the deer won't bother you because that's where I raise my vegetables."

So he went in there and had a very pleasant evening of sleep. The next morning he woke up to find he had slept on her compost heap, which was made up of seaweed. What she did was haul seaweed (I don't know how many bushel baskets of that stuff she must have hauled up from the ocean) and she would put in a layer of seaweed, a layer of soil, then some greens and stuff, and layer it up to get this enormous compost. Then you nibble at it from the ground level as it disintegrates because it makes wonderful soil. What is more, she needed it very badly because she lived on a granite hill; the soil was granitic with very little top soil, if any, in it. So James had a good sleep on her compost heap. [Laughter]

Further Notes on the Lester Rowntree Archive

Campbe11: I don't tell stories as well as Lester. I just hope she'11 feel like telling some of those tales.

Levenson: I don't want to make you tired, and we could stop, but I see you have neatly arranged a stack of papers. I feel that you must have your own things that you would like to say.

Campbe11: There are just a few things. I did show you her list of things she took with her on collecting trips. I found many lists like this because, evidently, she would forget what she typed up, or she'd forget something, then she would retype it. Or she would write herself a note, "be sure to take that with you." 
Campbel1: One that is rather interesting is her burro trip. On that, she was down to having to live completely by herself for five or six days. Among the things she took was hay for the burro, [laughter] which I thought was fine. She did take hammer and nails, a shovel, and a hatchet, and a compass. She knew how to handle herself in the wilderness. It is, I think, a very revealing list of the bare essentials, and she had them.

Levenson: I'm surprised the old burro needed hay because mostly, when I've been on trips, the animals pasture.

Campbell: Exactly. And hay is so bulky. but we do have a picture with her and the burro, and the burro is loaded at that point; his pack does go up pretty high. But, of course, her camera was along and the tripod, and those were great big, bulky things. So there we are.

This is an interesting one. These are the accounts of a trip up to Victoria and shows the meticulous way Lester operated. I think there was somebody with her on this trip. But she put down everything.* Her total gas and oil bill was thirty-five dollars. The total for auto courts was twenty-five dollars.

Levenson: Could we xerox this little account, then, and put it in?

Campbe11: Yes. The other things I really brought to show the various kinds of scraps of paper that she used. She had almost a shorthand. Like $i-n-g-$ at the end of a word is a little line. It took me a long time to be able to read her hand. Even now, there's some that I can't get.

She did write about her garden, describing it for each month of the year. She often referred to it in her articles. I think that she really would have liked to have written a very long article or book on her garden through the year. Her notes are mostly typed up and I can show you that.

But these scraps show the way she worked. For instance, she'd come in and it was March. She would say, [reading] "Oh, such a lovely day. The blue haze of the ceanothus goes gray among the new bloom of the dark pines." This is something she had thought of, and she saw the picture. So she writes it down on a scrap of paper and drops it in the box to file.

* See following pages. 
Gasoline on Trip from Cartal to Vancouvor and revirn.

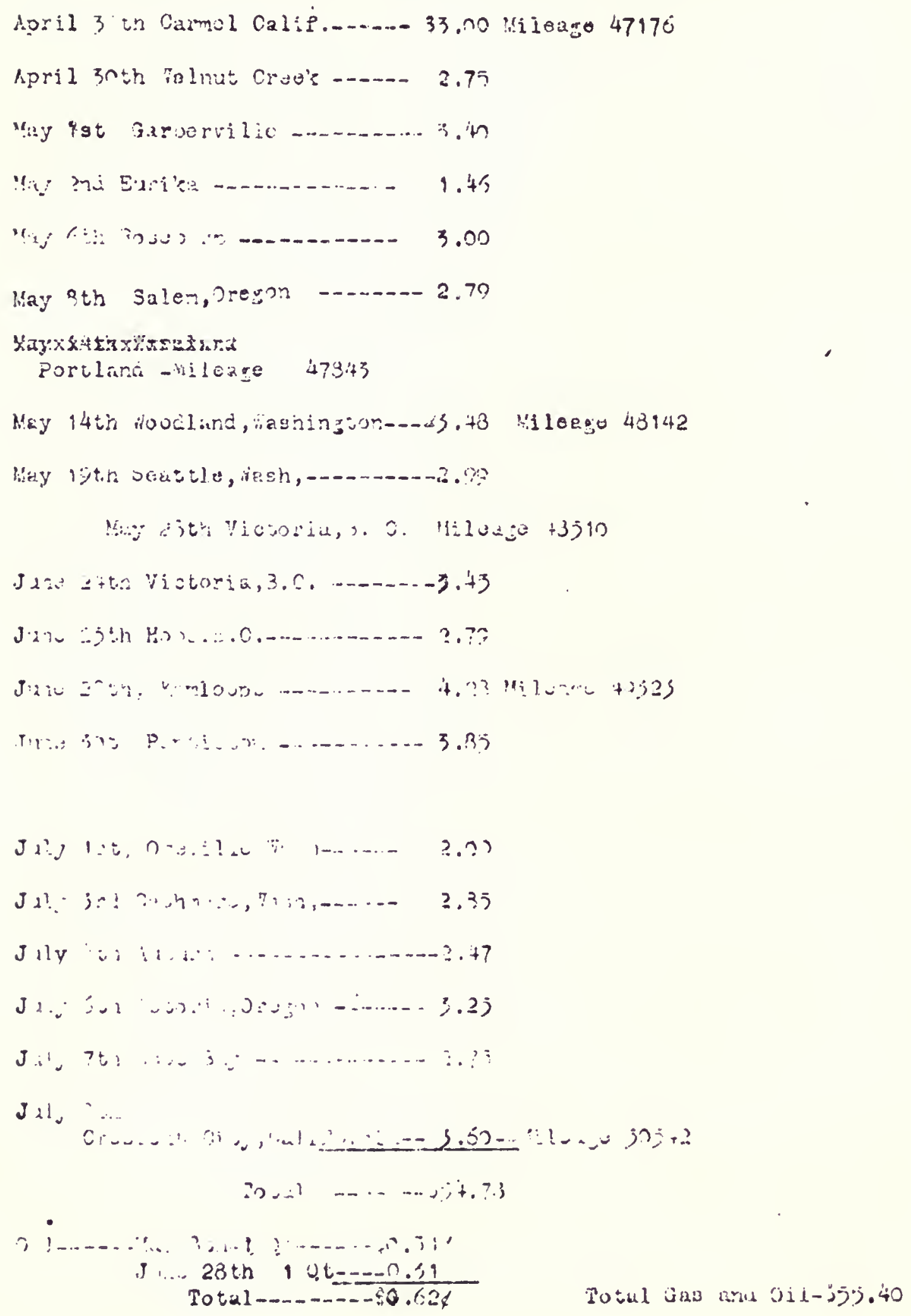


Campbell: When she came to write anything, she really had the material handy. I think her mind was going all the time on good phrases, good descriptions of various things. Then in collecting, for instance, she would do something--this is on the Jolon Grade, and maybe I'd better try to read this. She says, [reading] "Left of spot where high point is in fence. Just to the left before lunching place is gilia. Opposite side, humingbird sage. And more same with gilia farther off. A little farther on for gilia again. Wallflower around on the right; opposite the gilia, on a hill behind the fence, is the godetia."

This is the kind of notes she made so, in the fall, she could come back and find her seeds. This was her information.

Levenson: So that's written in pencil.

Campbell: Yes. This happens to be written on paper belonging to her husband, Bernard Rowntree, whose address in New York City was the Engineers' Club. The name of the town they lived in, Oradell, New Jersey.

Here is one of the topics that she worked on, road cuts, and how horrid they were, and how badly you needed to replant on them. This is a list that she developed of the plants that could be used on those spots. It's the type of thing--she was careful, really very careful, even though she was going a dozen different ways with the same information. She was able to cross-reference her things to the point where she knew exactly what she would find in one of her files. Well, that's enough to give you an idea of the archive. I think that's about it.

I think she was really a fantastic person. For somebody who never had any business training.

Levenson: And if you consider she was born twenty-five years before Queen Victoria died. I have to keep slipping my mind back into that time frame.

Campbell: I just hope Queen Elizabeth sends her a letter. Will she? On her hundredth birthday.

Levenson: I can arrange that she does. I don't mean to say that I'm important or anything, but I can just drop a line to the right person in England and make sure that it happens.

Campbe11: Because I know they do it for people in Canada, but I wasn't sure whether they would do it for anybody in the United States.

Levenson: By the way, is she a citizen, do you know? An American citizen? This is irrelevant, but-- 
Campbe11: I don't know. I never heard.

Levenson: I didn't ask, as I would normally do, what were her politics, what did she do in her spare time, because apparently she had no spare time.

Campbell: But her feelings were very strong on self-expression. To her, it was simply dreadful if children grew up in urban surroundings and never experienced nature. I have many pictures of Lester and Harriette and the children on camping trips. Often Cedric was along; sometimes he was not. But she made a great effort to see that her grandchildren really knew about nature.

This was why, after she had written her two important books, and her eyes were going bad, she wrote children's stories. They're all about next-to-nature. This, I think, was very important to her, that nobody should shut life, growth, out of their lives, that they must be in tune with the way the world works.

Levenson: I'm happy to say that the Berkeley Public Library has all four of Lester's children's books.

Campbe11: Oh, fine! Have you read them yet?

Levenson: Not yet.

Campbell: I'll be interested. Lester had her own copies, and she wouldn't even let me borrow them while I was staying in Carmel. They had to stay there. They were among her precious things. She wanted so badly to hand them on to her grandsons so their children could use them.* I can see this very strong trait in her.

She had a good many good friends. What I was thinking of, I was distinguishing them from strictly horticultural friends. Many of them she'd found through her horticultural activities, but she would keep it up and consider them as friends as well as horticulturists.

One of the most interesting ones is Liliane Wells. She was the wife of a physician. He was the doctor to the Sugar Pine Lumber Company in Oakhurst. It's in the mountains, just south of the south entrance to Yosemite. It was a fine place to go and get mountain type plants and Liliane and her husband had a home--

*One of Lester's great-grandchildren is reading Donnie in class in Oregon and enjoying it very much. [Ed] 
Campbell: I think it was four miles back in the woods, away from the lumber company, a gorgeous native plant garden. This is how Lester got to know her and she became a close friend of hers for ever after.

I found lists--for instance Lester would write, "this year I have sent Liliane so-and-so." Then there would be some other friend of hers and she would list the books that she had sent her. She felt deeply enough about these people to give them gifts out of her limited income. I think these people meant a great deal to her. In many ways, she was a warm person.

When we baby-sat Lester (her house was being done over, and we were all in a friend's house), Harriette and Cedric were away for a week. Jim and I, and our new corgi puppy, went down to baby-sit Lester. It was an easy job and our little puppy was one of her special friends. To this day she asks me--his name is a long Welsh name; we call him Charlie, because of Prince Charles. So she always asks me if Master Charles is doing well. There's a good sense of feeling and humor in her, still is. That wasn't too long ago, that was about five years ago.

Now, do you think we've done it?

Levenson: Why don't we turn it off, and if something occurs to you, we can always add it?

Campbell: I don't think of anything particularly right now. I think we've covered it.

Levenson: I certainly thank you.

CampbeIl: These are the things I was going to work on with you, and I think I have covered them completely. Probably more than you need.

Levenson: Oh,no. That's wonderful.

Campbe1l: I think that this is the kind of backing that you can use then, when you talk to Lester and to the family.

Levenson: Such a help.

Campbe1l: I'm glad to do it. She's been lots of fun. [Laughter] I've certainly enjoyed my work with her thoroughly.

Levenson: One of a kind. 
Campbel1: Yes. Well, every now and then I'd have to give up. I'd bring back boxes of her notes and then I'd work at them for a couple of weeks. Then I just had to give up. It was too much. But by now, I think I have everything except that red leather diary of her last trip to England. Now I've got that on the record. [The diary is now in the Rowntree archive at the California Academy of Sciences.]

Levenson: I'll talk to Harriette.

Campbe11: I think that's all.

Levenson: Thank you. 


\section{INTERVIEW NOTE}

Robert Ornduff: California Native Plants: A Distinctive Flora

The Life Sciences Building, University of California, Berkeley, houses among its treasures, the University Herbarium, the Jepson Herbarium, and Professor Robert Ornduff of the Botany Department. He not only directs the Herbaria, but also heads the University Botanical Garden and the plant section of Special Elementary Education for the Handicapped, which goes by the apt acronym, SEED. He was suggested as an ideal informant to place both the California flora and Lester Rowntree in their appropriate niches.

In spite of, or perhaps because of his busy schedule, Robert Ornduff fitted me in promptly. The interview took place in his office on September 13, 1978. Looking ready for the field in shorts and an open-necked shirt, Professor Ornduff answered my questions elegantly and concisely, fielded student questions and long distance phone calls, and then took time out for an unsuccessful hunt through the Herbaria guest books of the 1930s to see if Viscountess Byng of Vimy's and Lester Rowntree's visits had been recorded.

He notes Lester Rowntree's pioneering role in the promotion of the values of California native plants for horticultural uses. He is the first of our interviewees to compare Lester's role with that of John Muir. And he stresses the difficulty of measuring the influence of an author, particularly one like Lester Rowntree who write in that great but undervalued tradition of what the French so aptly call haute vulgarisation. "I would say that probably her influence is much greater than people realize. If you read articles often you're not aware of the impact or the origin of the idea" (p. 32).

The interview was promptly transcribed, edited, and returned with minor emendations for final typing and indexing. 



\section{CALIFORIIA NATIVE PLANTS: A DISTINCTIVE FLORA Robert Ornduff}

California Flora: Young, Rich, Isolated, and Well Studied

Levenson: It was very nice of you to fit me in today. Could I ask, Professor Ornduff, what your posts are at the moment at the University of California?

Ornduff: I'm a professor of botany at the University of California [Berkeley], director of the Jepson Herbarium, director of the University Herbarium, and director of the Botanical Garden.

Levenson: You seem to wear all the hats of Pooh-Bah!

Ornduff: I'm afraid so. [Laughter]

Levenson: What about in the California Native Plant Society?

Ornduff: I was a president. I think I was the third president of the society, but not for very long. I don't have any official connection with them except that I do a lot of manuscript reading for Marge [Margedant] Hayakawa.* I think she relies on me as a botanist to catch any bloopers that she figures she might not catch.

Levenson: I would like you to explain or summarize perhaps, the importance of California native plants--at least in the continental U.S. and, if you want to go on beyond that, to world flora.

Ornduff: In the area of California we have one of the richest floras per square mile on earth, and it's also a very unusual flora. California is essentially an island which is isolated from the rest of the continent by either deserts or mountains so that,

*Editor of Fremontia. 
Ornduff: essentially, our flora is also highly restricted and highly unusual because the climate in California is also a very unusual one which is matched only in four other places on earth. But I think compared with, say the Mediterranean region and with Chile, we are still richer per unit area. South Africa and parts of Australia may be richer than we are.

The California flora, for reasons that I cannot explain, is a very well studied one and many traditional methods of taxonomic investigation were, in fact, developed in California at University of California campuses as well as at Stanford and Rancho Santa Ana.

These techniques and attitudes have been adopted elsewhere in the country. Also, the University of California has been very important in training students who then became the faculty members of other institutions in the country. I think, for that reason, probably the California flora gets a little more publicity outside the state than it otherwise might.

It's rather curious that one can probably see more California native plants in and around London than one can in the gardens of almost any city in California.

Levenson: How do you account for this?

Ornduff: As you know, the English traditionally have been very avid horticulturists and in the early part of the nineteenth century, the London Horticultural Society [now the Royal Horticultural Society] sent David Douglas, as well as others, to specifically collect native plants of western North America for the gardens of Britain.

Many of his introductions are still grown. It's probably easier to buy California native plant seeds from English seed firms like Suttons and Thompson and Morgan than it is from Burpee or other U.S. seed dealers.

Levenson: In reading your volume in the University of Calffornia Press series series*, you made some comments on the recent development, in geologic terms, of the California flora. Is that particular to California or would it apply to the other regions you mentioned that are in some ways comparable?

*Robert Ornduff, An Introduction to California Plant Life, Berkeley, University of California Press, 1974. 
Onduff: I think it would be true of all of them. I think what is called the Mediterranean climate is generally now considered to be one of relatively recent origin. I think that's true elsewhere in the world where such climates occur. Because of the unusual nature of the climates, it has had a very striking effect on the general life history and strategies of the plants that occupy the climate.

Whereas in the eastern or even central part of the U.S., where there are prairies or deciduous forests, these are probably very old plant formations that go back millions of years. But we have a very recent and very actively evolving flora for the most part. On the other hand, the redwoods have been here for quite some time, and so have some of the other plants in the wetter parts of the state.

Lester Rowntree, Pioneer Promoter of the Horticultural Values of California Native Plants

Levenson: The California Native Plant Society, when it was formed, appointed Lester Rowntree as honorary president. Would you tell me a little bit about the role of the California Native Plant Society and why they chose to honor Lester Rowntree in this way.

Ornduff: I would say that if one goes back in the history of the state, say the last century, there are really only three people that stand out as being strongly interested in the horticultural values of the native flora. These were Lester Rowntree, of course, who was a very unusual person, Theodore Payne in Southern California, and Carl Purdy, who lived in Northern California.

So far as I know, neither Purdy nor Payne wrote or propagandized or really had the sort of interesting philosophical outlook and unusual personality characteristics that Lester Rowntree did. She is the only one of the three still living, and I think that she really is a symbol, a living symbol, of many of the kinds of things that the Native Plant Society is interested in.

She was a conservationist and was trying to promote the horticultural values of the native flora at a time when there was a great deal of disinterest in such things. It's hard to know how successful she was or really what her impact has been.

Levenson: That's in a sense what I was leading into. Have you met her yourself? 
Ornduff: I just met her once. I gave a talk to the Monterey Bay Chapter of the Native Plant Society, a few years ago, and she arrived. I don't recall talking with her, but I did meet her at any rate. I also knew her grandson, who was a graduate student here in geography, Rowan Rowntree.

Levenson: He's in Syracuse now, working in urban forestry.

How would you evaluate Lester's role in ecology?

Ornduff: I would find that very difficult to say.

[phone interruption]

Levenson: I asked you about her place in ecology.

ornduff: I would repeat that it's difficult to say. I don't know--the only book that she's written that I know of is Hardy Californians and--

Levenson: She wrote another one, Flowering Shrubs of California, and over a hundred articles.

Omduff: It's just difficult to know what influence people have. The same question could be asked about John Muir, who she resembles in many ways in her attitudes toward the landscape and the flora and the fauna.

I would say that probably her influence is much greater than people realize. If you read articles, often you're not aware of the impact or the origin of the idea that, in fact, you may adopt from a specific reading that you made.

I have very seldom seen any influence attributed to her but that doesn't mean that she wasn't a very important and influential person in a very subtle way.

Levenson: In a sense, this goes along with the popularization of California natives. She did have her seed business, native plant seed business--business wasn't her strong point. Again, I'd like you to comment on what you know, if anything, about her work in actually popularizing California natives and getting them into peoples' gardens.

Ornduff: Again, I find that very difficult to answer because when one goes into a nursery today, for example, and sees the assortment of California natives that are there, one has absolutely no idea who was responsible for bringing a specific plant into cultivation. $I$, again, don't know how responsible she was. I'm always disappointed at how few natives are stocked by nurseries and how few people are willing to give natives a try. I think, probably, 
Ornduff: the greatest boon to native plant horticulture was the drought we had [1975-1977], when people realized--well, I have native plants in my garden, which I don't water, ever, and they were looking very good last year when a few of the other yards in my general area were not!

But it's really difficult to say what effect she had in that area as well.

Botanic and Esthetic Values of the Horticultural Use of California Natives

Levenson: When one reads about introductions, there's very often a negative connotation. "Exotic" can be a dirty word. I know that this is primarily directed to Introductions in the wild. Eucalyptus in the Bay Area's an obvious example.

But you talk about California natives in England and in gardens in other parts of this country. What reactions do botanists, professional botanists, have to this spreading of flora from one geographical region to another and from the wilds to the garden? You sound very positive and very favorable.

Ornduff: I think it's always nice, as a Californian, to see a famlliar plant when you're strolling down the streets in Richmond on your way to Kew. I'm not reacting as a scientist. It's more as a person who grows plants, and most professional botanists are not very interested in plants as horticultural objects.

Many of the plants that are in cultivation are, in fact, relatively rare in the wild. Maintaining them in gardens is certainly one way of assuring their continuation as species. I'm sure, for example, that there are many dozens more Catalina ironwoods in cultivation than there are in the wild.

Unfortunately, from a scientific standpoint, if these cultivated specimens are of unknown origin, they are not of very great scientific interest. One can see what a Catalina ironwood looks like by walking down Oxford Street in Berkeley, which is certainly closer and easier to get to than the Channel Islands.

I think also California natives in horticulture have a certain positive propaganda value for the flora--I know there are visitors who come to California who already know about some of our plants because they know of them in cultivation and want to go and see what they look like in the wild. 
Levenson: How about hybridization? I know that Lester did very little and most of it was with gazanias. Do you, as a botanist, object to this in any way?

Ornduff: No, I think it's very interesting, actually, because there are hybrids--many hybrids--for example, known in ceanothus--California lilacs--which develop in the wild. One of the problems of hybridization is that very few horticulturists keep records of what they do. Even Luther Burbank, for example.

One doesn't know where his plants came from or what genes have been incorporated into them, so it would be virtually impossible to duplicate any of these. But I think it is interesting to see what will hybridize. I've even done some of it myself, more out of curiosity, but with some serious botanical questions in mind as well.

Levenson: Just for my own interest, really, are California natives regarded as exotics outside of the state or outside of their own natural habitat within the state?

Ornduff: Almost by definition, you'd say that they were. Some of them are so familiar, for example, coast redwoods and the Sierra big tree are very widely planted as ornamentals in Oregon and Washington. I think most people in the Pacific Northwest almost view them as their own because they are so commonly planted. That's probably true of a few other natives as well.

They're not exotic in the sense of looking out of place or extraordinary. California plants, by and large, look pretty much like plants elsewhere.

\section{Carmel a Choice Gardening Climate}

Levenson: Have you any suggestions, other than personal choice and beauty of the place, why Lester would have chosen Carmel? She came from New Jersey and she decided--when she was in her late forties--to die in Carmel. Well, she's having another half century of living and gardening and exploring from there!

But it does have an extraordinary rainfall and there have been reports of incredible performances of plants in her garden in the Highlands. Would Carmel be a fairly crucial sort of place for California natives? 
Ornduff: I think it probably has one of the best gardening climates in California. It is relatively temperate--I would guess virtually frost-free and relatively well-watered. I would say it, or the Santa Cruz area, would be almost ideal in terms of gardening.

Obviously certain plants would not do well there, but that would be true of any place in the state. If you look, for example, at what we have in [the Botanical Garden] Strawberry Canyon versus the native garden in Santa Barbara or at Claremont, we can do a lot of things that they cannot and vice versa.

We have great trouble with desert plants, for example, and Claremont has much less trouble because they're at the edge of the desert. I think Carmel would probably have a climate which would support a relatively large number of natives. And of course it's also an extremely beautiful area.

I'm sure when she came to Carmel, it must have been a very different place from now. It must have been very much like paradise, I would think.

Levenson: If you just go up the hill behind her house a matter of three or four hundred yards, it looks very much like pictures in 1929 when she first moved up there.

Ornduff: It's hard to believe there's really any place in California that looks like it did in 1929!

Strong Women in California's Native Plant History

Levenson: Lester had a very strong personality and still has. I suppose she would have to have had to accomplish what she did. Are you aware of any resentments or jealousies of her? Perhaps specifically as a woman in the field?

Ornduff: No, I've never heard any negative comments about her at all. Actually, she wasn't the only woman in California who was a very strong personality, who had interests of one kind of another in the California flora. We had our own Katherine Brandegee [1844-1920] here, who was obviously a very strong-willed and highly opinionated woman.

There's Alice Eastwood in San Francisco, who was a very distinctive personality. I don't know much about Mary Parsons, but she published a book of wild flower paintings which is still in 
Ornduff: print or has been reprinted. I remember looking at that when I was a child. Whether she had a distinctive personality to go along with it or not, I don't know.

I don't think, really, as a woman, that Lester Rowntree stood out as an unusual person, because there were other women in various aspects of California botany at about the same--or earlier than her time.

Levenson: That really leads into my next question. Whether you have any ideas on the reasons for the relative success of women in the fields of botany and horticulture. It's striking how many women's names turn up.

Ornduff: I honestly am not really very sure. I never thought about that. I don't know whether there's anything about having two X chromosomes that makes you somewhat more predisposed to working with plants! An awful lot of botanists, as you know, just view plants as objects of research and don't view them with any esthetic sense at all. That's also true of a lot of women botanists. They are not working with plants because they're beautiful, but simply because they are interested in answering certain kinds of scientific or theoretical questions that can best be answered by working with plant material versus animal material.

I'm not really sure that women are over-represented, but certainly--at least as far as the West is concerned--there have been some very prominent women for the last century, and there still continue to be a number of women who are very distinguished and well known botanists in the state.

Amateur Naturalists and the Pleasures of Knowledge

Levenson: Lester has commented at times that she had no university education, she had no professional training as a botanist. A lot of people have said, "Why bother? Why should amateurs bother to know the names of plants? They're just nice as they are." What would your answer be to that question--the justification for studying and naming of plants for amateurs.

Ornduff: Oh goodness! An amateur, by definition, is somebody who loves a particular subject--it's essentially like saying why bother to know the names of your friends? Or why bother to have acquaintances? I find that, first of all, when I'm walking along a trail, it makes it immensely more interesting if $I$ know the names of something that I encounter, and this is not only true of plants, but it's true of animals and rocks, minerals, and so on as well. 
Ornduff: From a practical standpoint, also, I think there's a good reason to know the names of plants, and that is, for example, if you were interested in growing something and you knew it was a member of the heather family, that would immediately tell you that the chances are very strong that it should go in an acid soil rather than an alkaline one.

There are certain generic and familial preferences of this kind. Or if you knew, for example, that you liked a California buckwheat and wanted something that wasn't exactly the same, but somewhat like it, but you didn't know what it was, how would you possibly go into a nursery and say I have a gray-leaved plant in my garden and I would like another one just like it?

I just cannot imagine anybody not wanting to know what the names of plants are, really--if they're interested in plants!

Summation

Levenson: Would you summarize for me, the importance and influence of Lester Rowntree in the world of native California plants?

Ornduff: As I said earlier, she's a person whose name I have known for many, many years, long before I met her, and she's the kind of person that I never really knew much about, except that I knew she must have been important or her name wouldn't pop up so frequently. My guess is that she has had a much stronger influence than most people realize, because of the prolific nature of her writings and of the very unusual nature of her personality.

of course, she was very strongly interested in horticultural native plants and this is something which I think is now really very prominent in the state, but the degree to which she can be held responsible, I really can't say. But I don't think that's an uncommon sort of thing, to have a sort of a mysterious person that you've always heard about but never quite knew how to pigeonhole. What is the influence of such a person on the course of a particular facet of history?

I don't think that particular question really can ever be answered except to say that her influence is probably much greater than most people realize.

Levenson: I'm happy to say that her books are being republished by Peregrine Smith. 
Ornduff: Well, that's good.

Levenson: It'1l be interesting to see what effect they have, what influence, on a new generation of readers.

Ornduff: I'm glad to hear that because Hardy Californians is something, as a matter of fact, that I think years ago, I wrote--I've forgotten who the publisher was--and told them that I thought it should be reprinted, but I think the timing was bad. Now that we've had the drought, and the Native Plant Society has been with us a few more years, I think they should do very well.

Levenson: Thank you very much. 


\section{INTERVIEW NOTE}

James Roof: Lester Rowntree: The Female John Muir

Jim Roof, now director emeritus of the East Bay Regional Park Botanic Garden and editor of Four Seasons, is a hard man to track down, a busy man, and a generous and salty man when it comes time to talk of a fellow traveler in the field of California native plants. As with all the memoirists in this volume, the name Lester Rowntree was an "open sesame." They delighted to honor her. We finally fixed on a date, July 28, 1978, and Jim made room for me in his studio apartment in Berkeley between piles of manuscripts, starting to talk enthusiastically about Lester as soon as I came in the door.

Jim began his work with native plants in the mid 1930s when he was nursery superintendent for Charles Kraebel, chief of the Division of Forest Influences. In addition to Lester, Jim pays special tribute in this interview to two "forgotten men" of California native plants, Kraebel and E. Denys (Ed) Rowe. Jim and Lester first met when she came to Berkeley to see the rows of native plants propagated at the Gill Tract. "We started to grow these native plants down there by the thousands. That, I think, is where Lester first saw and was thrilled by the thing she'd always wanted. She had been practically a loner in collecting wild flower seeds and wild shrub seeds--any kind of native plant seed at all" (p. 41).

Jim admired Lester's style--her style in writing, her style in living. See the anecdote on naming a botanic garden, (p. 46) and saving the Laurel Hill Cemetery manzanita, "I garnered it ghoulishly in a gunnysack" (p. 56). About her writing, Jim says, "She just went out into the field and enjoyed it, and passed her sense of joy on to the reader. It's a lot different from scientific writing. Yet her writing became more and more popular, and the young people today who are very scientifically trained and taught, enjoy her writing very much because she caught that era, you see, the $30 \mathrm{~s}$ and $40 \mathrm{~s}$. This was the primitive days of native plant exploration. . . She caught that era. Her writing's going to become more and more valuable as time goes on" (p. 59).

The only time Jim saw Lester really upset was when all the materials for the third volume of her unfinished trilogy on California natives, her tree book, were burnt when a heater set fire to her writing studio. "I said, 'You can have all my notes--anything you want--to get started again.' 'Oh, no,' she said, "I can't do it.' After a while she broke down and cried" (p. 77). 
Jim's interview gives a living sense of the community of pioneer native plant enthusiasts, from informed amateurs to professional botanists, of which Lester, despite her self identification as a lone hunter, was definitely a part. 
Roof Works as Nursery Superintendent for the U.S. Forest Service

Levenson: Mr. Roof, what was your job when you first met Lester Rowntree?

Roof: My occupation, when I first met Lester Rowntree, was nursery superintendent for the [U.S.] Forest Service in Berkeley and in other locations in California. For example, Devil Canyon in San Bernardino National Forest.

A nursery superintendent is available to move around. That is, if you're a good superintendent and know what you're doing, you will have charge of a local nursery. You also have a foreman there. We had a big Forest Service nursery in Berkeley and--

Levenson: Where was that?

Roof: Down at the Gill Tract, where the Western Regional Research Laboratory is; it's a United States Department of Agriculture building.

If someone had trouble at another nursery--if a man fell ill and there was no director there--if you had a good foreman, they sent you to other parts of the state--Feather River or Black Mountain or San Bernardino.

I was the nursery superintendent and Dr. Rimo C. Bacigalupi was the botanist. You can imagine me coming in and being the nursery superintendent and not knowing a thing about what $I$ was growing when we started work on California native plants.

I was pretty well versed in forestry. I had been a forestry student all through the latter thirties and I knew my trees, but what they were bringing in were just little plants and seeds. And they were foreign things to me. 
Roof: But Dr. Bacigalupi steered me right. He was my mentor and kept me straightened out on things--taught me what the plants were and when the seeds germinated he said, yes, that's penstemon or that's gilla, and so on. So I learned my native plants mainly from him.

Then, going down to Southern California, I had the tremendous advantage of learning the native plants of Southern California by running the Devil Canyon nursery for a number of summers. Then of course the Feather River nursery, I learned the plants of the Sierra, and so on. Moving around like that, I had a very broad spectrum in native plants.

I can remember things that we worried about in those days that seem to insignificant now. But people were at each other's throats in the thirties and forties.

There were two great botanists then, Leroy Abrams at Stanford and Willis Jepson at the University of California. When you started discussing a plant, a lot of these pugnacious taxonomists would thrust their chins out and say, "Who do you follow?" You'd say Jepson. They'd say, "Well, he's a fool." [Laughter] You were declasse the moment you opened your mouth.

I used to say, "I don't follow anyone. I want information." You get more that way.

Charles Kraebel: Forgotten Man of California Native Plants

Roof: I was nursery superintendent in Berkeley and, eventually, for the branch of forest research, I became nursery superintendent for the whole bunch of nurseries. The other men were not too much interested in native plants. But the man who was interested in native plants is probably the forgotten man of native plant horticulture. They always talk to you about Jepson and Abrams and Rowntree, and so on.

One of the greatest native plant men in the state was Charles - his last name was spelled $\mathrm{K}-\mathrm{r}-\mathrm{a}-\mathrm{e}-\mathrm{b}-\mathrm{e}-1$, and he's very uncelebrated as a native plant man. He was, I think, one of the foremost native plant men that we ever had. For example, he was chief of the Division of Forest Influences at the research station in Berkeley. Among its branches, Forest Influences included the responsibility for erosion control on mountain roads in the national forests. Kraebel insisted on using native plants. No exotics, or very few. 
Roof: Sounds simple now, but in those days it was not. They didn't know how to grow native plants, they couldn't germinate the seeds of native plants. They had no way of acquiring stocks from nurseries.

Kraebel said, "All right, we'11 set up a seed research project and we'1l get someone in there and learn how to germinate the seeds of native California plants." And we did. He hired me in 1935 and we set out to learn how to germinate the seeds of native California plants. This was the first big native plant seed germination research project.

The germination of seed plants that had never been germinated before, to anyone's knowledge, produced a great number of plants. Most people never having seen these plants, were fascinated by seeing plants that they had only heard about or read about--seeing them lined up in cans, first by the hundreds, then by the thousands.

Charles Kraebel, being a very progressive man, decided that he would furnish the national forests with any kind of native plant that they wanted. He initiated a big nursery project at the Gill Tract. We started to grow these native plants down there by the thousands. That, I think, is where Lester first saw and was thrilled by the thing that she'd always wanted. She had been practically a loner in collecting wild flower seeds and wild shrub seeds--any kind of native plant seeds at all.

One day, I guess someone must have told her--this was way back in the dim beginnings of native plant horticulture--that if she wanted to see native plants in containers by the running dozen, or hundred, she could see them in Berkeley.

\section{First Meeting with Lester Rowntree}

Roof: She dropped by that nursery one day and she was thrilled to the bottom of her soul by seeing these things she'd advocated for years, all of a sudden right before her. She just was shocked by it. She just couldn't understand how or why anyone had gone to the trouble of germinating these seeds and canning the plants. This huge nursery, of which I have pictures--thrilled her unbelievably. She couldn't get over it.

Levenson: In this interview, when you speak of native plants, do you mean California natives? 
Roof: California native plants. Sure. That was Lester's big thing all the way through. Her books are Hardy Californians and Flowering Shrubs of California. She never intended to depart from the California floral region again. She began elsewhere, but when she finally got down to it, she was Californian, all the way.

When Lester first showed up, I had no idea who she was. It was very possible that $\mathrm{Dr}$. Bacigalupi had written to her, or knew of her, and invited her up to take a look at these native plants in the nursery. He's still very much unchanged and he's now seventy-seven years old and lives in Berkeley, near the university.

He was the official botanist for the Forest Service in those days. He went on to become the curator of the Jepson Herbarium and retired from the University of California about ten years ago. He and I still get together and go hiking and talk about old times and botanize, especially on Mt. Tamalpais.

I had no previous knowledge of Lester. I don't think I knew that she had become famous. Charles Kraebel, for Christmas, along about 1939 or ' 40 , gave me her shrub book. Amongst professionals, it was looked down upon. The professionals used the standard manuals: Jepson, Abrams, [P.A.] Munz, [Howard] McMinn, which were considered to be professional texts.

I have Charles Kraebel's copy of Lester's shrub book that he gave me one Christmas. He says in the inscription, "It may not be technical, but it has a lot of good stuff in it." I read it. I suppose I may have met Lester before that time, but at least I knew her by 1939 .

Levenson: What did you think of the book?

Roof: I thought it was wonderful. I caught the style right away. I was not a scientific person. I'm a little more scientific today, but not totally. A botanic garden director stands halfway between scientific botanists and the public.

One day, Dr. Bacigalupi came with Lester Rowntree. We11, I had many visitors. I always showed them around the nursery. I was properly courteous to her and then later on, we warmed up. We spent, I think a whole afternoon looking at the native plants and propagating facilities. The germinating rooms were at the university itself. My office was there. The plants were taken from there to the Gill Tract and canned.

When the Gill Tract overflowed, the university gave us several acres of the Schmidt Tract at Cedar and Sacramento. So, you see, Lester had quite a day. She was just overwhelmed with the number 
Roof: of native plants. She said she had no idea that anyone was growing native plants and here, all of a sudden, she was drowned in them.

Then it got late, and here were three native plant people jabbering at each other, so we went to dinner. Then we got her a motel room down on University Avenue. She said absolutely not. We insisted she go down there and she said, no, she would not go down there.

Levenson: Why not?

Roof: She said she hadn't slept under a roof for fifty years, and she had no intention of starting that particular night!

Levenson: [Laughing] About how old was she at this point? She was born in 1879 .

Roof: Well, that would be about 1939 or ' 40 .

Levenson: So she'd have been sixty, sixty-one?

Roof: Something like that, but at that time, she was extremely vigorous. She was still going to the Sierra and climbing the highest peaks and doing everything that she'd always wanted to do.

She asked what open space was available. We1l, the university owned most of the land around. We didn't know where to put her. We finally settled on Strawberry Canyon where we had some experimental plots. So we went up there and unlocked the gate and drove into these plots, and she sald, "This will do very nicely." [Laughter] She lald her sleeping bag on one of our lysimeters [gesturing]. Lysimeter is spelled l-y-s-i-m-e-t-e-r. It's a rain measuring gauge on a little plot of ground that measures the amount of rainfall that falls on that particular little square.

She just put her sleeping bag inside the lysimeter edges. There was plenty of room in there. She had a good night's sleep, but I don't think we saw her again the morning. We gave her a padlock and told her she could let herself out.

The next morning, when she was supposed to come down and say good-bye, she never did. She just disappeared. This was a very common practice with her. I've known several people like that. It doesn't hurt your feelings at all once you get to know them. They just vanish. They don't stay around to say good-bye or I had a good time yesterday, or thanks for this or that. They just go. I think she just left the next day. 
Roof: We learned that she would not sleep in a building. I think she first started sleeping indoors only about ten years ago, when she was ninety or so. She's not amenable to it yet. It ruffles her feathers to think that she has to sleep indoors. I'm not sure that she's never sneaked outdoors--she would if they let her. But her son says that the changing weather at night might not be too good for her.

I began to see a little more of Lester. I saw her once or twice. Then the war intervened, and $I$ went into the army. I was gone until 1946, and I didn't see her all through that time. I guess I saw her again about 1947.

Division of Opinion in the Forest Service: "We're Not Pansy Planters"

Roof: The Forest Service, with its tremendous collection of native plants--no matter how many were shipped out to the national forests --and they were shipped out by the hundreds of thousands from nurseries here and elsewhere--there were thousands left.

The professors of botany, Sierra $\mathrm{Club}$ people, people who were interested in the natural scene, became conscious of this accumulation of native plants. There were some very rare species there that had never been seen before as young plants. We had devised methods of germinating the seeds, and we would often have on hand the first "block" of canned stock of many native plants ever grown. We were using very original and up-to-date methods of germinating the seeds.

We didn't send out the rarest plants. We just couldn't bring ourselves to. We'd worked hard on them; we'd never germinated the seed before, and we'd never seen these plants in containers. We'd taken good care of them and we felt that we had an idea how to grow them. We didn't want to ship them out into cold hands that would say, "Oh, thanks a 1ot" and then put them away somewhere and let them die of drought. We just couldn't bring ourselves to ship certain things.

Levenson: Can you remember which were your particular favorites at this period?

Roof: They weren't favorites, exactly, they were just damned hard to get. The California bush poppy would be an excellent example of that. Dendromicon harfordij--it came from Catalina Island. No one had ever seen a seedling of it. No one knew how to germinate 
Roof: the seeds. And everyone wanted it. We used wax solvent. We used everything we could think of or lay our hands on. We used a solvent that dissolved the waxy oil out of the seeds. A few germinated, perhaps a dozen, but they were the first of their kind to be germinated by horticulturists.

We canned those and had them in cans, and they were blooming in the cans. Lester was ecstatic over them. But we thought it would be a mistake to ship those out. We didn't want the Forest Service people to have them.

Roughly half the forest supervisors in the state were on our side and roughly half were dead against us. They said our business was growing timber, not planting ranger stations with native flowering plants. We're not pansy planters, they said.

So we just held back shrubs that we knew were not replaceable. There are still lots of those in the botanic garden in Tilden Park.

A Note on the Establishment of the East Bay Regional Park Botanic Garden, 1940

Roof: Professor McMinn at Mills College became very much interested in that collection. Here were these plants lying around in tubs and pots and boxes and barrels, and all sorts of containers, and he said, "My God, this is a better collection of native plants than the botanic gardens at Santa Barbara or Santa Ana contain. Something's got to be done with it. Northern California does not have a native plant botanic garden."

So he went to the East Bay Regional Park District and asked them for free land on which to establish a native plant botanic garden. He had good leverage there because Aurelia Reinhardt was the president of Mills College at that time. I don't know whether you remember the name.

Levenson: Oh, indeed.

Roof: She was a very famous woman. Aurelia Reinhardt was on the board and when McMinn went to her, she proposed the Park District giving the land, the Forest Service giving the trees-a joint project which would cost the park very little. She was very soundly backed by August Vollmer, the famous police chief of Berkeley. 
Roof: Between Reinhardt, Vollmer, and McMinn, it was a sure thing. Because Vollmer was a very forceful man and a very broad-minded man. He had interests in many things, especially in native plants. He was born and raised in Berkeley. He had fished up and down Wildcat Creek when there was still trout in the stream. He was the most enthusiastic backer of that botanic garden.

Botanic or Botanical? Lester knew

Roof: One day a park workman came out to the garden--it was in 1940-and said, "We're going to make the garden sign. What do you want on there? Regional Parks Botanical Garden?" Lester was just standing there. She said, "Absolutely not!" She said, "It's a botanic garden!" They said, "No, no--botanical garden." She said, "Botanicals are things that you find in gin, like juniper berries. Botanicals are sold in drugstores!" And she was vehement about it. So it became the Regional Park Botanic Garden.

There are a lot of people who still do not understand that. On all the correspondence for forty years in the Regional Park District, most of it was addressed to the Botanical Gardens--why plural and why botanical, nobody knows. Lester knew what was correct.

I'd never run a botanic garden. I'd worked with Van Renssalaer at Santa Barbara and so on. I got out my literature and it's the Santa Barbara Botanic Garden and the Rancho Santa Ana Botanic Garden.

She's the one who stopped them from making our sign botanical garden, because I was busy and I just wanted to get rid of those sign-carving characters. She's the one who saw to it that we had the right terminology on the sign.

Levenson: That's a lasting memorial to Lester, and preserved, thanks to you, in your anecdote!

Roof: I was grateful that she was there that day. She was right-absolutely right. 
The Horticultural Bond

Roof: Then Lester came back into the picture. When the botanic garden was established, she was again just overcome with joy. Then she began to visit, and she visited the botanic garden as often as she could. Lester brought her camera with her and she would photograph native plants in bloom in the botanic garden. Some of those pictures are in her books. A lot were lost in that fire that put her out of business.

My first impressions of Lester were not tremendously strong. I didn't know that she was difficult to get acquainted with. I never treated her with any more courtesy or deference than I would any visitor. I didn't realize that a lot of people just didn't get to talk to her. [Laughter] Maybe that had something to do with my getting along well with her later on. But I think the great bond was that we both grew plants. We were not botanists.

As I remarked to you over the phone, we were horticulturists, and we were interested in growing plants. She was interested in gardening--she'd always been interested in gardening. On the East Coast, everywhere she went, she was a gardener. She was not a taxonomist, not a botanist. She was a horticulturist.

Interpretive horticulturists stand halfway between the lay person and the scientist. The director of a botanic garden must be like that. He cannot surrender to the technical side. What the director of a botanic garden is, in a very real sense, is a transmission belt between the lay person and the scientific person. The scientific botanist goes along learning new things and giving them names, arranging the families, doing all the taxonomic work. The director of a botanic garden takes those plants, grows them and puts labels on them. He has to play both sides of the fence.

He has to find out what he can from the technical people and he has to reduce the scientific knowledge to terms that the layman can understand. You soon learn, as a botanic garden director, who the stuffy ones are, who you don't want to play with. Then you find the fine people who realize that if the public doesn't somehow understand what they're doing, they may have their tax funds cut off. So you do get these wonderful people in taxonomy, who are delighted to help botanic garden directors put proper names on their plants.

I would say that Bacigalup1 was one that I knew. Dr. Robert Ornduff at the university was very much bent toward informing the public in as simple terms as possible of the most 
Roof: technical details that he could think of. He's a brilliant but simple man, and he's all for the public knowing what they should know about native plants. And Dr. Ledyard Stebbins of the University of California, Davis--world famous geneticist who talked on equal terms with people like the late Robert Oppenheimer or Ernest Lawrence. I've heard him talk to people like Glenn Seaborg and also to children. He's a real genius.

Levenson: That's a great gift.

Roof: I've heard him talk to children very intelligently, not coming down to their level, but making himself understandable to them, which is something quite different.

So, in botany, there are these people who want native plant botanic gardens to have good plants in them, and the plants to have the proper names on them--which is important.

Lester liked what people called dirt gardeners. Lester and I never said dirt gardeners: we said soil gardeners. I made a hit with her one time. When I was talking with a third party, they said, "Have you got any good dirt?" I said, "Dirt is what you find behind little boys' ears." [Laughter] Lester almost had a conniption fit laughing.

I don't know whether she had given it any thought before then, but just a while back, I read where she had written or told someone that you had to use the word, soll or earth; not dirt. I think she got that from me. I always resented people asking where they could get some good dirt. I'd say, "Well, behind little boys' ears. That's some of the best dirt in the world." [Laughs]

Levenson: May I just interrupt here?

Roof: Sure. Interrupt me.

Levenson: I used to say to my boys, "Wash your ears. They're getting so you could grow an apple tree in there." I think that's an old English saying. 
Some Rowntree Anecdotes: The Flying Iris; Fruit Picking in the Valley

Roof: I remember many visits of Lester. Some of her visits were more or less like the Oakland Raiders. A car would come whistling by and a can with a plant in it would come flying out. [Laughter]

She'd be off into Trinity County and bring an iris or something, and come by and throw it out and say, "Here, I found this" in such-and-such a place. You'd shout at her and she'd go up the road shouting and she wouldn't stop.

Levenson: Good gracious!

Roof: One of the most beautiful plants in the garden, I think, is Iris bracteata. That iris has been in demand by people who can't find it in the wild. I said, "Where is it from?" She said, "Trinity County."

Dr. Leo Brewer, an iris specialist, said later on that it couldn't have come from Trinity County. It had to come from suchand-such a place. When we backtracked, Lester said, "Yes, I did go there. Now I remember where I got this." She went by and said, "Trinity County!" just so she could keep on going.

A lot of her plants took hold. Some of them didn't. But she'd dig them and can them for us. Then she'd come by. Sometimes, she'd stop, but my recollection is that she went on more than she stopped.

Then lots of times I'd be out in the field. She'd come by and I wouldn't be there. When I did see her, she'd shake both fists at me like this [gesturing]. "Where were you when I came by on such-and-such a day?" Then she'd scrawl me a letter.

This led to a very peculiar thing. I guess it was probably the most emotional scene we ever had. She made only enough money in collecting seeds to barely eke out a living. She collected seeds and made lists, and sold the seeds in little packets here and there, and she did make a living doing that.

But she could not afford a good car. She would get junky old cars and have some of the local boys piece them together down by that Standard station there in Carmel Highlands, or wherever she could get somebody to put in baling or hay wire and get the thing put together. Then she would take off for the Sierra, which was the great love of her life. 
Roof: Her cars would always break down in the heat of the Central

Valley. Just when she was set to make the Sierra, they would break down. She would have to stay in the Valley and pick any kind of fruit that was available. Peaches--she picked peaches; she picked hops. Lester picked grapes, all kinds of things.

The hell of it was that while she was sweltering in the heat and so on, she could see the Sierra. This was a killer. It just broke her spirit.

Lester, the successful Author, and Her Brand New Car: No Vapor Lock Now

Roof: She wrote her book [Flowering Shrubs of California] and from it-in those days, she realized quite a sum. She had gotten five or six thousand dollars from that book. Stanford University Press gave her five thousand dollars. Then the sales started coming, slowly but steadily.

I'm not very good on human relations--always wrapped up in native plants and what-not. And very slow to think. When you run a botanic garden, you have to think slowly, but you have to think right. You don't want to make a mistake planting a redwood tree or fig tree where you know you'11 have to cut it down twenty years later. You have to think things out very slowly. So I always think very slowly. This was just a plece of good luck.

Lester drove up to the garden in a car, the like of which I'd never seen before. This was one of our points of difference. I can remember that car plainly. It was a station wagon and she had the top of it put on specially for her. It had a steel deck throughout. It had no seat next to the driver, so she couldn't take a hitchhiker.

Her sleeping bag was in the back. The whole car was full of seed-collecting envelopes and brown paper bags. She had all her gear for the Sierra and a brand new car. I swore up and down it was a Cadillac. She said, "Nonsense." Lester, herself, doesn't remember what kind of a car it was.

It had a swivel front seat. There was a little table behind where she could get out a typewriter and swivel that seat around [gesturing] and type. She'd had it made. That seat was on a steel shaft where she could turn, bag seeds, or turn clear around and do secretarial work in back, and so on. I didn't know what to make of $1 \mathrm{t}$. 
Roof: Now, I didn't know it at the time, but her friends had accused her of--what do they call it--ostentatiousness. She'd become a successful writer and here she was, splurging her money on this new car.

When I looked at it, I had heard these rumors--that she had gone holty-tolty and that she had spent all her money on a car, a brand new car, and so on and on. When she drove up, she stopped in a huge cloud of blinding dust.

At this time, I made a very fortunate remark. I walked around the car, thinking, "What can I say? I don't have a car this good" and so on. But there was something in the way she treated that new car--getting it dirty and dusty--that puzzled me. I finally walked around to the driver's side, looked her straight in the eye and said, "Lester, this time--this summer-you're going to make the Sierra."

Levenson: How beautiful.

Roof: She shed a couple of tears and she said, "Jim, you're the first one who's understood." Since then, I've been solid with her.

No one else had even thought about her trials and tribulations for so many years. So many summers lost away from the mountains. They didn't think of that. I don't know why I thought of it. I just felt that, by gosh, that thing was going to go across the valley without having vapor lock or any kind of trouble. She was going to make it.

It took her across the valley without any trouble for a number of years. This was, of course, what she wanted. Not ostentatiousness--she wanted security. She wanted to get over to those mountains. She didn't want to sit in the valley, picking hops, which she did a lot of, and watch the mountains all summer.

She wanted to get into the mountains. Then I said, "Lester, this time, you're going to get into the mountains." She broke down; then she took off. I kidded her. I said, "You know, you're the only one I ever saw who had a custom-made Cadillac." "Oh bosh," she said. "It wasn't a Cadillac." I said, "Well, what kind of a car was it?" She says, "I don't remember." [Laughs]

I don't remember. It was a very odd-looking car because it was a wood-framed station wagon.

Levenson: Harriette said it was a Packard.

Roof: Could have been a Packard. Did somebody say it was a Packard? 
Levenson: Harriette, her daughter-in-law.

Roof: Harriette ought to know! [Laughter]

It was a very expensive car for the time. You just looked at it and you knew that she was not going to have a bit of trouble, any more than John D. Rockefeller. She didn't care how much it cost. She spent most of her money on it and saved just a couple hundred dollars.

She didn't need the five thousand dollars. She needed to get across the valley. And you could see that she was going to make it.

\section{Rapport Firmly Established}

Roof: After that, I never had a bit of trouble talking to her or getting strangers to go with me and talk to her. Like today, people say they want to meet Lester Rowntree and they carry a book with them, very shyly, and hand it to her. She says, "Oh, get away with that stuff!" I tell her, "Here, just sign this and don't give us any argument" and she signs.

I remember one of the terrible things that happened [chuckles] was that they all decided to celebrate her eighty-fifth birthday.

Levenson: Who's they?

Roof: There was Vern Yadon of the Marine Institute and Lois Robinson. Lois Robinson was the wife of the famous Clyde Robin. Clyde Robin was an assumed name. The man's name was Robinson. He was a seed collector and he and Lester were like that [fingers together] because they were both in the same business. They traded seeds and customers and native plant information.

Robinson died in the Sierra. Lois Robinson then became Lester's best friend. Lois and all of her friends decided to give Lester her eighty-fifth birthday party. It was held on the lawn at Lois Robinson's place in Carmel Valley. It was a huge lawn. It was rather a hot day--it was in August, you know.

Lester said she would not attend a party like that, that she was just not interested. Lois said, "Oh, for heaven's sake, your friends do want to wish you a happy birthday." Lester put it off for two or three days. Then she said, I'll go to that party on one condition: that Jim Roof is there." 
Roof: Lois phoned me right away and said, "Will you come down for the birthday party?" I said, "lieavens, in August? That's a terrible time. I don't have a chance to get a vacation." She said, "Lester said she will not have a birthday party unless you're there." I said, "Well, if you put it that way, Lois, I can't very well refuse." [Laughs] I thought, good heavens, why me? I went there and was sitting on the lawn. They were having drinks and one thing and another. I remember getting pretty well crocked.

After a while, Lester came strolling in. Vern Yadon had parked his car around the back, and she came strolling in from that direction, sneaking in where the fewest guests were, made a beeline for me and sat down and started talking about native plants. And that's all she did--talk about native plants.

Occasionally, the young people who wanted to meet her would come up and I'd stop and say, "Lester, there's someone here who wants to say hello to you." A young girl or someone would say I'm so and so. I had to make a little chitchat, and then Lester would just get back on to native plants. That's how she spent her eighty-fifth birthday.

Lois [laughing] had this huge group of people. They were mostly concentrated over on one side, where the bar and food happened to be. Then, in midafternoon, they brought out a huge cake. Someone had gone to great trouble. They had an escholzia on the cake on a white frosting. They had blue-eyed grass--I can remember very well--carefully etched on there. Sisyrinchium. The cake was covered with native flowers. Whoever did it, did a magnificent job.

Levenson: It sounds magnificent.

Roof: Lester had to cut that cake and she said, "Tommyrot!" I said, "Lester, these people have gone to a great deal of trouble to honor you. Quit being a curmudgeon and cut the cake!" She said, "Oh, you too! You're joining in the conspiracy!"

I said, "No, I want a piece of the cake!" "Oh, she said. [Laughter] "Here! Which one do you want?" I said, "Sisyrinchium!" Then she got interested in the cake.

I've got some old-time colored pictures of her doing that. I don't know where they are--they're around somewhere. People ask me for these things and I can't find them. If you think this place [Berkeley] is bad, you ought to see my place over in Orinda. [Laughter] I've got a room over there, stacked to the eaves. I don't know what to do with those things. 
Levenson: If you come across them, the best thing to do with any Lester Rowntree papers is to give them to the California Academy of Sciences, because they've got the Lester Rowntree archive.

Roof: At the Academy? I've got quite a few letters from her.

Levenson: They'd be gratefully received.

Roof: They should certainly not be in my possession because people won't know what to do with them. I did one Four Seasons* here--a girl lying in a bed of clarkia. Lester todk me to task severely. She said, "You are putting man before nature. The girl is crushing down a bed of flowers. She should not be doing so. Do not exalt the human over the natural." I wrote back and I said, "Models have to work, Lester. You, of all people, are denying this girl her twenty, twenty-five dollars. The girl is not crushing any flowers. We selected a place without them, very carefully. You ought to know that we would do that, and I resent your criticism. Furthermore, it's better that the girl make twenty-five dollars in a bed of clarkia, than in some man's bed!" Boy, did she blow her stack! I think I may have a copy of that letter somewhere.

Levenson: I'd like that, I really would.

Roof: I said, "You ought to know better, having gone through the vicissitudes you did. And the Depression."

She got the point but she also got mad. I called down there in a few months, on one of my regular visits, and Cedric said, "Well, I think it's safe to come by now. I think she's cooled off." [Laughter]

I went down, and she acted as if nothing had ever happened. She just let it all go. Then she would write to me about different things. I've got all of her letters. You could tell that she was losing her sight because the letters would be getting larger and larger. Instead of a little note on a single page, it would take greater letters this big [gesturing, two or three inches] on two pages or three pages.

We never had any trouble. I never backed off from her. She'd tell me that I must let her know when I was coming down there. Now, that was not always possible. Sometimes, I'd be coming up the road from San Simeon and I would just drop in.

*Four Seasons Vol. 4 No. 1, July 19, 1971. East Bay Regional Parks District. 
Roof: "You told me that you would write beforehand and let me know when you're coming down!" I said, "I didn't have time."

It never made any difference.

\section{"I Knew Manzanitas Before They Had Chromosomes"}

Roof: On the manzanitas, she said--one of her famous quotations that I haven't seen in print anywhere--she was teaching, or talking to a group of young people. I never got to see her with a group of young people. Harriette told me that, quite of ten, a group would come from some school or other. Lester would consent to see them and talk with them.

Lester was after me to do the manzanitas. It's absolutely a Herculean job. The manzanitas--I got some criticism from a famous geneticist a while back, who said that I was no taxonomist. I said I couldn't agree with him more. I never pretended to be a taxonomist. I'm a horticulturist.

I said he's the first one who's recognized it and I'm very grateful to him.

Another thing I said, "The taxonomist had never succeeded in working out the manzanitas."

Levenson: Would you just say to me again what you said off the tape?

You were describing to me what was involved in studying a group like manzanita--the master plan.

Roof: Genetics a lot. Chromosome numbers. People have fiddled around the edges of arctostaphylos for years without ever being able to solve the problem. I told this geneticist that, although I wasn't a taxonomist, I was proud of that. I'm not a botanist. I said the botanists and taxonomists have not been able to solve the manzanita problem, so somebody's got to do it.

When Lester was talking to this class, she made a mischievous allusion to arctostaphylos, and she said something about "Jim Roof is working on them and he's going to work them out. I'm sure he'11 do it." Then she said, "He's going to use chromosome counts. I knew the manzanitas before they had chromosomes." [Laughter]

Levenson: I like that! 
Roof: It's the way her mind ran. "I knew the manzanitas before they had chromosomes." That, you know, is--in the old days.

The Laurel Hill Cemetery Manzanita: "I Garnered It Ghoulishly in a Gunnysack"

Roof: It's been alleged that she pleaded with the city of San Francisco to save the Franciscan manzanita. We were the ones who did it. We started working on that in 1938. Someone has written somewhere that she pleaded with the city of San Francisco to save an acre or so of the old Laurel Hill Cemetery for a city park, for a little botanical reserve.

Now, I know it was not she who did that. It was Alice Eastwood. Lester, of course, had no little interest in saving that manzanita. She had one on her place at Carmel for a long time. We tried to salvage a piece of that and failed. It was a miserable sort of thing. It was there in full cry and we decided to take cuttings from it, and we did. We got some seed off of it. Everything failed. When we went back in the right season, the whole thing had died.

Of course, we didn't care too much because we just wanted another authentic Laurel Hill specimen. We had it, ourselves, in the botanic garden and really didn't need any more. It was just a thing of which you could say, "This is an original from Laurel Hi11."

Levenson: Had she taken a cutting or seed?

Roof: She ripped up a whole plant. One day I said, "Lester, we want cuttings and the seeds off your Franciscan manzanita from Laurel Hill Cemetery." She said, "Help yourself." I said, "By the way, how did you get ahold of that manzanita?" She looked at me and finally she said, "I garnered it ghoulishly in a gunnysack."

Levenson: [Laughing] I like that!

Roof: She sneaked into the old graveyard at night, ripped the plant out, put it in a gunnysack, put it in her car, and drove off to Carme1. [Laughter] "I garnered it ghoulishly..." This was Lester.

And she got the plant to live! Had she been the only one who tried that, she would have had the only plant. Everyone would have had to go to her place to get it. Fortunately, we got a great 
Roof: number of plants over there--1938 to 1941--then the Laurel Hill Cemetery--all the cemeteries were wiped out. It was a disaster.

Levenson: Built over, do you mean?

Roof: We lost, I think--In California, the old San Francisco cemeteries were our greatest loss--our only loss, probably. With experience, you get an idea of where to go and what to get and what to save, and you become very professional about it. But in 1938, we were not very professional about it.

We went to Laurel Hill and we got the Franciscan manzanita. We left things behind. We said, "Well, we've got that; what's next?" What we did was lose several forms of manzanitas from the Masonic Cemetery, the only dune manzanita in San Francisco; we lost the dwarf creeping manzanitas on Mt. Davidson. It was a disaster which I've had to work out mostly through a process of induction.

Fortunately, there was one plant left at the Presidio. It's still there. From that, we were able to go back and do a detective story and piece the whole story of the Franciscan manzanita together. But if we had lost the one in the Presidio, we'd have been up salt creek. It's quite a job, but by now, I know what we lost.

And I've also written of what we've lost, so that generations to come will realize what happened in that catastrophe in San Francisco. Mt. Davidson and those cemeteries at Geary and Masonic were treasure troves of plants. When we went in and got the Franciscan manzanita, we took the type specimens that Alice Eastwood had described and ignored everything else.

Had we done it today, we'd have taken everything in sight and sorted it out later. We didn't go up on Mt. Davidson at all. Terrible--

Levenson: These were built over, I assume.

Roof: Oh yes, subdivided. Absolutely. They threw out the forty-niners. They were supposed to have reinterred them in the cemeteries down the Peninsula, but I rather doubt it. I suspect that a lot of them are still there, bulldozed over. 
Lester's Contributions to California Native Plants: A Joyous Writing Style

Levenson: What would you say were Lester's main contributions to California native plants?

Roof: Her contribution to California native plants? I think that no one has ever approached her writing style. She has a style that looks upon native plants almost anthropomorphically and gets away with it. She doesn't attribute human traits to them and she doesn't write purple prose about them, but she can certainly conjure up beautiful writing about native plants without being maudin. Her style is easy to read--leads you on through one of her books, leads you through her articles--lots of articles for little magazines, like the Journal of the California Horticultural Society. I don't think anyone's ever written the way she does.

Levenson: I think that's very much in an English tradition.

Roof: Yes. But very light--not heavy at all. I remember her famous line about Western yew. At the time she wrote, the Western yew was never along a road. You had to walk to see it.

We hunted Western yew all over Lake County when I worked there during the Depression. It was rumored to be on the north side of St. Helena; rumored to be here and there on the road to Hopland, and wherenot.

Lester located some Western yews in different places--while she was out hiking. These locations she put in her book, near the end of a chapter. She writes that you walk up this creek or you walk down that trail and then--at the end, like a little afterthought--she says, "If you don't want to walk, God help you-you'11 never see it." [Laughter] She didn't give a damn about the scientific community. That sentence would never appear in a scientific work--if you don't want to walk, God help you; you'll never see it.

They say, very drily, it's located on such and such branch and fork or the west, or the south fork of the Smith River. Then, in parenthesis, California Academy of Sciences, 102039; then the name of the collector.

Lester never would go for that. I'm not mad about it. It helps to verify certain things. If you're trying to explain a very difficult problem in taxonomy or in manzanitas, for example, it does help to refer to a number like that so people can look at the specimen and tell what it is. But Lester wasn't that way. Her writings do not include any scientific references. 
Roof: She just went out into the field and enjoyed it, and passed her sense of joy on to the reader. It's a lot different from scientific writing. Yet, her writing became more and more popular, and the young people today who are very scientifically trained and taught, enjoy her writing very much because she caught that era, you see, the $30 \mathrm{~s}$ and $40 \mathrm{~s}$. This was the primitive days of native plant exploration, horticulture, a very primitive time for native plants.

She caught that era. Her writing's going to become more and more valuable as time goes on. The California Native Plant Society has three times tried to get McMillan and Company to redo Hardy Californians. McMillan won't go for it--I don't know why.

Levenson: May I interrupt?

Roof: Yes.

Levenson: Peregrine Smith is going to republish both Hardy Californians and the Flowering Shrubs. .

Roof: High time!

Levenson: Isn't that delightful news, though?

Roof: Yes, it is. They said, oh, there'1l be a mixup in names. The names have changed since then. I said, "So what? Put an asterisk or a number after each one and then put an index at the end and say the modern name." of course, old-timers know those names that she used. They were the proper names in that time. That's no reason not to republish a book.

Levenson: We11, I'm very happy about it.

Roof: I am too. I think the Native Plant Society should be very happy about it.

Lester's Horticultural Approach

Roof: I believe that she contributed more to horticulture by her writing than she did by actually growing things. She had, at one time and another, some of the most famous plants in California on her place there in Carmel. The trouble was she wanted to spend the summer in the Sierra. Once she'd go away, the plants would die. 
Roof: She would be satisfied with that, because when she came back, she used the beds for the current bag. [Laughter] I was always--

Levenson: Didn't her partner, Lila Clevenger, try to take care of things while she was gone?

Roof: Yes, but no records were kept. And it could hardly be said that horticulture was taking place. However, she did have a sure sense of the fact that a plant would grow or would not grow. She didn't care too much, I don't think. She hated to see some plants go under, but she'd get Penstemon purpusii from the sumit of Anthony Peak and grow it. If it grew, and bloomed, and she knew the kind of soil she had put it in, she was not heartbroken when she'd come back and it would be dead--she'd put something else in its place.

She was running through more plants that way, whereas in a botanic garden, you try to keep everything alive. The more plants she had, the more time it took to care for them and the less time she had to ramble. What lester wanted to do was ramble. She didn't want to stick around and take care of those plants.

I think what she did was to try many, many plant species and had rather a good instinct for whether they would grow or not, and then said, "I grew this." You'd go down there, it wouldn't be there. I'd kid her: "Hey, where's that Penstemon purpusii?" "Oh, it died while I was up on my pack trip" or so on, and she didn't care much about it. I didn't either.

I would rather she were roaming than sitting around taking care of the plant. But the more plants you collect, the more time you have to spend taking care of them.

Roof: I drove up to her place one time. There's a very famous native plant down in San Diego County. It's really a Mexican, Baja California, plant. It's called campo pea--it's a beautiful magenta color. Lester had a big live oak at that time, near her entrance. I think it died and had to be cut down.

I drove up the driveway and parked. She hailed me and said, "Come on up." I went up and I said, "What's the idea of growing bougainvillea all over your front? A fine ad for native plants you turned out to have in your front yard." She looked at me for a while and said, "Go look again."

While she was making tea, I walked down. She had gotten one of these campo peas growing and it had run and flowered along a 
Roof: branch one year, then run along another branch and flowered another year. This was its last year. They're very delicate plants--a little something goes wrong around the root and they die. The blooms of this thing absolutely filled that oak tree.

Levenson: Amazing!

Roof: There wasn't an oak leaf in sight--just this enormous campo pea, which she had planted under that oak.

I came back and said, "That's one of the nicest bougainvilleas I've ever seen." She said, "Perhaps you'll think twice before accusing me of growing bougainvillea!" She had the biggest campo pea I've ever seen north of San Diego County.

She got a seed or two from some friend down there, put them under that oak tree. That's the sort of thing she did. Now, when that oak tree filled with those blooms, she had the most enormous campo pea in the world. But she wouldn't do 1 t over again. She'd go on to something new. That was enough.

I think that was a good system--just to enjoy that enormous campo pea for two or three years. Then, when it disappeared, well, you didn't go and try to do it over again. You'd already done that. That was the biggest one I ever saw.

Levenson: How did she feel about exotics?

Roof: She thought they were fine if they fit into the picture and didn't spread all over. She said--she was quite hooked on putting in a Gray Garden. I think that would have been in her third book.

There are lots of gray plants that fit right in with native plants. I can't remember too many of them now, but we have our gray plants--our atriplex, the salt bushes, soft sages and buckwheats. She was interested in putting in a complete gray garden. for it.

You know, she did a lot of landscaping for people and got paid

Levenson: What did you think of her landscaping?

Roof: I never heard any complaints about it. The only landscaping I saw was her own home. That's all. But she didn't make any mistakes in landscaping. She knew her plant materials. If you know your plant materials, you're not going to go too far awry.

She believed that if the gray exotics that she mixed in with the gray native plants didn't dominate the native scene, they'd be fine. See, the trouble with exotics is that they overrun everything in the vicinity. 
Roof: Your native California plant is adapted to stay in one place. And it has its enemies that keep it in check and hold it in one place, and it doesn't overrun the world. Exotics are always brought in without the parasites that keep them in check. So they run rampant.

Lester believed, as I do, that you don't despise exotic plants. Lester loves exotic plants the way I do.

If you plant a Lombardy poplar, you get a beautiful autumn show of tall columns in brilliant yellow-gold. I couldn't do without the Lombardy poplars, especially along 395--the road from Reno down to Carson City and on down to Los Angeles, through the Owens Valley.

If you plant a Lombardy poplar, you have one. If you plant a red liquidambar from the East Coast, with brilliant red leaves, you have one. But if you plant one of these damned Eucalyptus globulus, the first thing you know,it's either you or them.

Of course, Lester despised the South African ice plant, the hottentot fig. There was nothing that she could do about it, but she just despised it. That was her attitude toward introduced plants. If they kept their place and fitted into the scene and didn't try to pig the whole environment, she was for them. But if they were aggressive and crowded out the native plants, she was against them. We all are.

This is practically a rule with the native plant people. For the average public, no.

We have tremendous fights over cutting the Eucalyptus globulus down--tremendous fights over cutting out Scotch broom. Some people say, "Well, it's the only thing that blooms here!" We tell them, "Do you want to live in a country with nothing but Scotch broom in it?" They say, "We11, the native plants are not so great. They don't bloom very much."

You've got to look at them. They're a little more delicate. You have to have an eye for that sort of thing.

Lester's landscaping was, I think, well done. I hope she got a lot of money for it. I don't think that she did because she wanted to ramble too much. Whenever Lester would make a few dollars, she was off. She never stayed around to see how some of her projects came out. [Laughs] She was gone. 
The Monterey Flora: Lester Saves Ceanothus Rigidus Albus

Roof: She knew the local plants there around Carmel. She did an awful lot of walking, she did a lot of investigating, she knew where there were rare things. If she had not known what was around Monterey, we would have lost some very nice things down there.

She knew where that lone plant of Ceanothus rigidus albus was on Yankee Point. She pointed it out to Lewis Edmunds. He'd never heard of it. She told him, "If you're interested in getting something new and different, why don't you go down and get that white ceanothus?" He said, "What white ceanothus?" She told him, and he told me on a tape recording, "I went to see Mrs. Rowntree and she told me about this white ceanothus."

He went down to Yankee Point and collected it. It's still being used. It was only a single plant in the wild that he knew of.

A year ago, March, Jim Griffin and I found another one.

Levenson: Rea11y?

Roof: - Up in the state park at Point Lobos. He took me there--he wanted a manzanita identified. I went up to identify the manzanita-here was this thing in full bloom. I said, "You want to play around with common manzanitas when you have rare things like this?" "My goodness," he said, "what's that?" I said, "That's rigidus albus. That's the second plant known in the Monterey area, and it's on public land." The shrub is not on private land like the one at Yankee Point.

Then Lester would get peremptory about certain plants. When she couldn't get out to get ahold of something, she'd send me a peremptory order, "Go do this thus-and-so."

That enormously expensive house that sits on a rock near Carmel Highlands--I don't know whether you've seen it or not-a lot of people look at the sea view there and they don't even see the house.

Levenson: I know the one you mean.

Roof: It's fitted in the stone. 
Roof: One thing about Lester was that although those people down there were, lots of them, multimillionaires, they knew of her, and some of them knew her. She was never denied access to their property.

I still feel I should go down there some time. The man who owns that house is named Dan James. She'd send me these letters and say, "You've got to go and see Dan James. Tell him I sent you.

"He has a dwarf cypress that's in his yard, overlooking the sea there, and you've got to get some seeds off that. Well, I went there, I don't know how many times, and no one answers when you knock.

I told her one time, "Call Dan James." She phoned him and they said, "Well, he's in Los Angeles." I still have that order and I still have the location--the name, the phone, and everything. I can't get that cypress out of there. All I need is a handful of cones.

After a while, she forgot about it and didn't hold it against me that I didn't get that cypress out of Dan James' yard.

Someday when I go down there, I'm going to tell her, "Look, you can get Dan James to get some cones off that cypress. Now, let's do it. You've been wanting to do that for twenty-five years. Let's do it."

There's a dwarf cypress she wanted. That particular dwarf cypress--she says it has a very peculiar structure to it. This is the sort of thing she had an eye for--the odd.

Then she would want to grow it herself. When she got to the point where she wouldn't grow it herself, she would send to someone, like Lewis Edmunds, and say, do this--do that, or send something to me and say, do this, do that--do it right away, you know. I'd get a letter sometimes just saying, "I want to see you." It was almost invariably about some native plant that was in danger, or she wanted to get that thing safely away before somebody bulldozed it or trampled it out.

While she was active, she was an invaluable person for that Monterey-Carmel area, where she'd keep her eye on things. If she thought something was endangered, she'd let you know right away and give you the imperial summons to come down and get it--to get seeds or cuttings--"We've got to save this."

Levenson: Did you go? 
Roof: Oh, yes! I went down and got a lot of things that she recommended I get down there. We got trailing Arctostaphylos pumila. I did a lot of work down along the Big Sur coast--Arctostaphylos edmundsii was the big thing down there. I worked that whole Monterey coast at her behest--around Garrapata Creek, Rocky Creek, and Bixby Creek.

She knew that coast intimately. She'd not be able to go a long distance--then she would just go south--down towards a town, but down into the wilder parts of the Big Sur coast. She'd also roam the hills up behind her place when she was able to.

Lester Extends the Range of Rhus Integrifolia

Roof: One day, Lester said, "Oh, I did a terrible thing!" I said, "What?" She said, "Well, I planted Rhus integrifolia in my back yard. I said, "What's wrong with that?" "Good heavens," she said, "it's going up the hill like a grass fire. Go up and look."

I went up and sure enough [laughs], she'd gotten Rhus integrifolia way down by San Juan Capistrano. It doesn't naturally come up the coast. A nice shrub--no great harm--she picked a good strain of it.

Rhus integrifolia, the old lemonade bush, is an evergreen. There's one like it out in the garden now--not nearly as good; it's deciduous. It's bearing red berries.

Lester's Rhus integrifolia bore huge clusters of fruits. You couldn't see the fruits because they looked like they were encased completely in wet sugar. It's one of the great sights in native plants.

You cut a twig clustered with the fruits, put it in a glass of water and stir it--put a little sugar and you've got lemonade. They call it lemonade bush. That white is pure citric acid.

On one of my trips down there a couple of people came along to see Lester. We looked at her plants all around the yard. Then we went up for tea and cookies.

I had one of these sprigs of this Rhus integrifolia and I kept sucking at it--it was delicious. It was a hot day and it was like having solid lemonade. But it took all the skin off my lips and off my tongue--it's a strong acid. I learned the hard way-it was horrible--I was unable to speak. When I'm unable to speak-[Laughter] 
Roof: Lester said, "Why don't you say something?" I said, "Oh my God! I'm horribly burned." She said, "Have some tea. Tea is good for a burn." I said, "Oh, that's the last thing I want." I finally put some cold tea on it. But I was out for a couple of days.

She did have a marvelous strain of that Rhus integrifolia. She had thought not to put it in her yard. She thought, "I'II go up the hill and plant it up the hill. Nobody's going to bother it up there."

It's very steep grassland. Here the thing had not only taken hold, but had seeded up the hill. Here it was going up--heading for the sumit of the Santa Lucia mountains!

I said, "Hell! Lester! They'1I just include it in the books as an extension of range someday." I said, "I won't say anything about it. I won't say that you did it. They'll include it as an extension of range and say that it extends from Baja California all the way to Carmel Highlands, California." [Laughter]

She said, "Oh, I hope nobody ever finds out that I did that." I said, "I don't think it matters--I don't think anybody cares. If you'd have picked a bad strain, it would have been a mistake. But this is a good strain, so let's accept it." So she hasn't worried about that for a long time. I was able to put her mind at rest.

Actually, I should make an official note of her range extension. I do run an official publication [The Four Seasons] and it would be no trouble to do so.

Before you do something like that, you should put it into your journal, which is supposed to last in libraries forever--and you put in there that you, on this day, sowed the Antioch primrose at Pt. Reyes, or whatever. Then people say, "I found a new station for Antioch primrose." Someone who knows the literature goes back and says, no, that was sown over there in an attempt to save it in 1971.

It's quite all right to do something like that if you feel that you're on safe genetic grounds. That you're not going to ruin the genetics of the area over there. Also it's safe if you publish it.

Lester did that with Rhus integrifolia. She's responsible for that extension of range up at the Highlands. I've got to get that down on paper. I never remember that. It should be published so that people will not suspect that it's native up there. 
Roof: Right above Lester Rowntree's place, long after she's gone, people will say, "Lester Rowntree lived down there. She did that, so it's quite all right." [Laughter]

\section{Conservators of Native Plants: A Small Fraternity}

Levenson: What about Lester's writings on conservation?

Roof: I remember the huge battle she had when they put the clover leaf in at the summit of Carmel Hill--Huckleberry Hill--the freeway through there and the big interchange.

She went after them, fang and claw. They were going to plant the newly-cut banks with exotic plants and she got. them to plant the banks with the native arctostaphylos, hookeri, pumila and tomentosa. Not too much of that remains today. At least she got them to do it. She got them conscious of the fact that they had ripped out native plants and they were putting back exotic plants. She couldn't stand that. She had her way about it. broom.

of course, today the whole thing is being overrun with Scotch

Conservation itself--1t's hard for people today to realize-some of the young students who work with me go out on field trips wath me and so on, find it difficult to realize how primitive things were in 1940 in the way of native plants. Conservation was not very strong. I was into conservation then, but not very deeply, through friends, Arthur Blake of the Sierra Club, and others.

I would listen to him and I learned about conservation from him, but the Sierra Club was doing the conservation and they were not much into native plants. They were interested in setting aside King's Canyon National Park, and fighting to keep Hetch Hetchy from being flooded. Big things like that.

I recall Lester wasn't into that. She had her hands full. Almost everyone who was working in any kind of a conservation program in those days, had much more than they could handle and each one was rather highly specialized. I can't recall more than ten people in the native plant movement in those days. 
Roof: The Forest Service had a little cadre of native plant people, but they didn't stay in the profession. When the emergency funds were gone, they vanished and no one's heard of them since.

Levenson: By "emergency" do you mean the New Deal period?

Roof: Yes. Roosevelt made funds available in 1934 and cut them off, of course, when the war began in 1941, and early 1942. Conservationists were very small in numbers then. They didn't have any clout. They had few spokesmen. The Browers [David and Anne] were just young people in those days--Dave Brower was just a kid. It was almost forty years ago.

The native plant people were a small fraternity. The young people who today see native plant people everywhere they turn, believe that in 1940 there were native plant people too--there weren't. Kraebel was the great pioneer in native plants.

Lester's Influence on Young People

Levenson: What was Lester's influence on young people?

Roof: I rather suspect that her influence on young people was very marvelous maybe for the one day that they talked to her, but she hasn't taught regularly enough to have a continual, steadying influence. I don't think that Lester is exactly a teacher. I think that in talking to young people for one day, she's marvelous. But I don't think that she could sustain a class. I don't know.

The young people just look upon her with awe. I'm not sure they do so because she's a wonderful, inspirational teacher or whether it's because she's so old. They say, "My God, she's a hundred!"

You sit with young people and watch them. They want autographs and they want pictures, and they want recordings. But as far as learning anything from her, I'm not sure that they do.

Levenson: How do they get to hear of her in the first place? Have they read her writings?

Roof: The girls who work out in the Regional Park Botanic Garden have read her writings. Word of mouth gets around and they say, "Have you read Lester Rowntree's book?" "No. Who's Lester Rowntree?" A lot of people think she's a man. Then they pass the word one to the other and then people say she's the famous one who lives in 
Roof: Carmel. They say, "She lives in Carmel? How long has she been at this?" "Oh, she's a hundred now," they say. Oh, my goodness--then they want her autograph.

They take her books down there. Some of them go through old second-hand bookstores to get copies of Hardy Californians or they will get copies of the Flowering Shrubs of California and take them down and have her sign them.

I know two of these young girls who continually want to go back. They want to go back. I don't know whether they want to look upon her to venerate her, like the four-hundred year old monk in Shangri-La, or whether they feel they're really getting native plant wisdom from her.

Lester and I talk about things that were commonplace thirty, forty years ago. Maybe these young people are getting a look at the early days of native plants. That could be the attraction.

Lester remembers those days and wants to talk about them, and the young people sometimes don't know what she's talking about.

"The Destruction of California"

Levenson: What are some of her favorite stories?

Roof: What Lester usually talks about is the destruction of California. She considers this to be the great tragedy of her life, or of anyone's life. She thought that California should not have suffered the fate that it has. She'd say this is not an industrial state, and they've made it the biggest industrial state in the Union. For heaven's sake, why? And she really--the thing that hurts her most is the change in California.

I think that most of her ire is directed towards Los Angeles. Los Angeles--I can remember Los Angeles in the twenties--the early twenties, too, where in spring, you drove across huge fields of phacelia. The road was paved, but if you took a side road and followed the main highway south, you simply went across long, rolling plains of phacelia.

These plains are no longer there--the wild flowers are no longer there. But one of the most fortunate things in California was that there were very few rare plants that Los Angeles affected. If the rare plants had been down there, we'd have been whped out. As it was, we fought a pretty good rearguard action. 
Roof: Lester thinks that everything is gone. She hasn't been able to get out into California and look around for twenty years, since she was eighty. Even then, I remember her plaint around her eighty-fifth birthday, and before that, that she was glad--this was her most common expression--she was glad she saw California when she did and that she's glad she doesn't have to look at it now--that she can't get out and look at it now.

I keep telling her, "Lester, I agree with you that a good many of the places are gone, but they're not all gone. If you could go up to your camp on Slate Creek or Sawmill Creek, you'd find it absolutely unchanged--actually improving. If you went up to Round Valley, to Covelo, if you went up to the Yolla Bollys, there are a lot of places that are good or better than they were when you were roaming around in them" But she doesn't believe me --she won't take my word for it. They're gone as far as she's concerned and that's it. She just won't listen.

I don't remember any really outstanding classical anecdotes because mostly we talked shop. [Chuckles]

E. Denys Rowe: Another Forgotten Native Plant Man

Roof: As I told you, she'11 say, "Have you seen Ed [E. Denys] Rowe lately?" or something like that. She just, I think, refuses to admit that he's gone.

Levenson: That's very sad.

Roof: It is. She hasn't asked me that lately. But he passed away a long time ago. I think that she had a secret admiration for him. He was a very dashing, very gallant man. An Irishman--a tall, thin Irishman of the type you seldom see. I remember on three different occasions, she asked me what Ed Rowe was doing. He'd been long gone then.

If I ever find his obituary, I'll print it, because he's one of the forgotten native plant men. E. Denys Rowe. It was always capital E--then Denys was $\mathrm{D}-\mathrm{E}-\mathrm{N}-\mathrm{Y}-\mathrm{S}$. Naturally, everyone called him Ed.

He was a very brilliant man and Lester absolutely adored him. He had charge of the reconstruction of La Purisima Mission [near Lompoc], which was a very responsible job. He had a bunch of dumb brutes who were his superiors! He would reason out something about the mission; then go digging around in the sand--the 
Roof: sand dunes had blown over the mission--and he had a CCC [Civilian Conservation Corps] crew there. He'd go digging and find exactly what he wanted. He'd say, "Now, the other thing must be here." He'd go dig there and he found it.

His story alone is really worthwhile--aside from Lester, because of his brilliance. He reconstructed that mission. He found the original Father Payeras, who was buried under the altar. The people had moved the altar from one end of the church to the other because the wall opened and a sand dune blew in over the altar. So they just picked up the altar and put it at the other end of the church.

He said, "It's not right" because things didn't look right with the altar facing that way. So he went back to the other end of the church, dug the sand away, and dug up Father Payeras, who was supposed to be buried in Spain or Mexico City. Mission.

Ed worked out of the archives of the old Santa Barbara

We were all in love with that mission garden because Ed combined the old Spanish plants, that the mission fathers had brought, with native plants. He was a native plant nut--just like the rest of us [chuckles]--so he would go down to the Channel Islands and sail out there and get plants off the islands, which was very hazardous in those days. The owners didn't like visitors.

Lester was always waiting to hear of some exploit of Ed's. He had them by the score. But I really had to tell her one one night. Van Renssalaer at Santa Barbara and Ed from La Purisima, and I used to meet at the Santa Maria Inn. [Chuckles] Ed Rowe was a real Irishman--he drank Bushmill's Irish whiskey, which is a pot liquor and it's not homogenized. If you leave it on a shelf too long, the oil comes to the top.

A bartender who knows his stuff, takes Bushmill's and shakes it and mixes it up. Well, one night, we were heavily into a discussion on native plants--he'd say it is and I'd say it isn't. There was a young bartender and he forgot to shake the Bushmill's. And Ed-C"I say it is, by George!" and he tossed this off, and in a minute, he passed out.

So we laid him reverently on a divan in the lobby near the bar in the Santa Maria Inn. Van and I had to go to dinner. Ed was out for--I don't know how long--I'm not sure that he had dinner. 
Roof: When I came back to Carmel, Lester said, "How's Ed?" I said, "The last tiue I saw him, he was horizontal." So she said, "What happened?" I told her. She said, "Oh well, Irish whiskey never hurt an Irishwan." [Laughter]

"I've Got to Have Riy Tea"

Levenson: Iid Lester ever drink?

Koof: No. But tea--my God! You'd go down and talk to her for a while and she said, "I've got to have my tea!" I don't know how she ever paid her tea bill. She would get one can of tea-Constant Comment, or a can with a press-in lid about yea big [about eight inchesj--she would plunge her little hand in there and get her entire hand full of tea leaves. Now, one of those would make her oniy two servings of tea.

Levenson: Good lord!

Roof: Yaybe that's why she lived so long. She drank tannin. I don't know now sne carried enough tea in the mountains to get by--unless she went without. Or made tea out of something up there like Labrador tea or what have you. She made the most horrendous tea. She'd say, "I've got to have some tea. Do you want some?" I'd say, "Lester, what else do you have?" Oh, that tea.

She used to be active around the house. I guess Harriette makes her tea now. She would grab a huge handful--I mean all she could hold in her hand, and throw it into the pot of boiling water. Sine was not what you call an English tea drinker. She believed in using the entire supply--all sine had on hand--she put in the pot.

I don't know who furnished the tea. I don't know whether Harriette bought the tea for her, whether Cedric bought it, or they bougint it by the barrel, or what--but she consumed enormous amounts of tea. She didn't drink more tea than the average person would--she just drank a high concentrated extract of tannin and survived it. Maybe that's the secret--I don't know. I should have started it some time back. She may be preserved in tannin. [Laughter]

You know, a woman gave me a picture of Lester, and I lost it. She's smiling, she's got brown bangs--she's small, but you can see 
Roof: that she's a hiker. You can see that she's agile. You can see that she's ready to go, could go anywhere she wanted, and just be absolutely happy with her lot.* It was published in Sunset magazine. I think the article was on three famous women, or something like that. There were two other pictures on the bottom of the page. The third one was Lester. There was a page of text. At the bottom, as Sunset frequently does, there were pictures about this tall [about three inches]. The one to the right is Lester, just lying on her left elbow and smiling at the camera. It's one of the finest shots I ever saw of her. It looks nothing like the Lester I knew. From the very first day that I met her, I never saw a picture like that. She must have been around forty or forty-five. I've never seen a picture like that.

Formation of the California Native Plant Society

Levenson: How much did Lester have to do with the founding of the California Native Plant Society?

Roof: I don't think anything. The California Native Plant Society was formed as the Friends of the Regional Park Botanic Garden. They have done a very bad thing. They walked away from the botanic garden and left it in the hands of incompetents and are about to lose it.

Lester was, of course, revered by the time the society was formed in 1965. She was about eighty-six or so. The infamous William Penn Mott, Jr. took charge of the Regional Park District as general manager in 1962. A couple of years from then, he tried to destroy the garden. He very deliberately tried to destroy it.

Levenson: Why?

Roof: Mr. Mott is an extremely mediocre park man. He has no talent for anything that he's ever tried to do in parks. He's been a total fallure in park work. But he has a very extraordinary talent for advancing himself, covering up his mistakes, and simply proceeding onward to higher positions.

*See page 103a. 
Roof: I think the botanic garden--it's hard for me to evaluate just exactly what was happening then. I always tried to keep the botanic garden on a high plane of excellence. I don't think Mott could stand that. Someone told me that I had a name that was as big as his at the time and that he couldn't stand that.

Leaving myself out of the equation, he chose the most mediocre men that he could possibly choose for his staff. This is a symptom that is well known in park circles. If you're a very mediocre park administrator, you have to shine above your subordinates. So you choose very mediocre subordinates that make you look good.

Mott was a top hand at that. He was one of the most authoritative bums that we ever ran into. Mott is actually an incompetent, untrained, unimaginative--almost a completely worthless park person. And he got to be the head of the State Department of Parks and Recreation in Reagan's administration.

This is done simply by controlling your own publicity department. For example, we're pushing now for some kind of legislation that will prevent public agencies from having their own publicity departments. You never hear anything bad about them. You never hear anything bad about that rotten crooked East Bay Regional Park District because nothing bad ever escapes through the publicity department.

Levenson: That figures, doesn't it?

Roof: It certainly does. It's something that's got to come to follow Jarvis-Gann.* The East Bay Regional Park District used to furnish the most inexpensive recreation in the United States. It gave the best recreation for the least price.

The budget when I started over there, was less than a million dollars a year. The budget remained very low practically proceeding with the increase in inflation until 1962 when Mott took over. He immediately started to run up that budget. He wanted money to spend, and he spent it. He failed on every project he tackled. He just failed.

When he attacked the botanic garden to wipe it out--he wanted the little budget that we had. It didn't amount to much, fifty thousand a year or something, at the time. He and his successors have run the budget of the park district up to $\$ 32$ million.

*A California constitutional amendment which radically lowered property taxes. Passed June, 1978. 
Levenson: The East Bay Regional Park?

Roof: $\quad \$ 32$ million. Yes. Jarvis-Gann nailed it good.

Levenson: Is that for the whole state system or just for the East Bay?

Roof: Just for the East Bay Regional Park District. Jarvis-Gann--I always felt that something like Jarvis-Gann was aimed directly at that park district like a cannon. You should hear them cry!*

Levenson: Well, back to Lester--[Laughs]

Roof: Back to Lester.

We almost lost the garden, you see. The local people gathered and Lester wasn't in on it. After the Friends of the Regional Park Botanic Garden succeeded in saving the garden from Mott--and that's a very complex story. The Friends of the Regional Park Botanic Garden became The California Native Plant Society.

Unfortunately, they just walked away from the garden, leaving it without any organization. You see, the Strybing [Arboretum] has the Friends of Strybing Arboretum. UC has the Friends of the University of California Botanical Garden. Santa Barbara has the Friends of the Botanic Garden. UC Davis, the Friends of the Davis Arboretum. And the society walked away from the Regional Parks Botanic Garden and left it hanging there. Believe me, the cutthroats are at it.

But don't worry about it. We're going to start opening the ball on them in about two weeks.

Levenson: Good Iuck!

Lester's Writing Studio Burns: "No One Had What She Had"

Roof: We never had any set agenda down there at her place. I would say that if we hadn't seen each other for six months or a year, we'd start talking where we left off. It was always about native plants. She just didn't care to talk about anything else.

Levenson: Did she ever discuss her problems with Lila Clevenger or E.K. Balls with you?

Roof: No, she never did.

*The Regional Oral History Office plans to record an oral history memoir with William Penn Mott, Jr. 
Roof: The only time she ever broke down was when her little studio burned up there. She passed it off to people--she said, "Oh, it's nothing.'

I knew that the little studio had burned. You know what happened up there?

Levenson: Not exactly.

Roof: She had one of these old oil heaters [gesturing about two feet high]. They were the most reliable things in the world. They had a circular wick on them--

Levenson: Yes, I know the sort.

Roof: She had had this place built especially small so that the oil heater could do the job--it was a kerosene heater. I had never known any of those kerosene heaters to do anything really dangerous. They smoked a lot.

If you went away and the wick happened to run up, boy, did they smoke! They'd smoke you out of the place.

She had this place built in the brush, above the house, and it appeared that she was not at home. People would drive up there and she could look down and see them. If she saw I was calling, she'd come down, but if she saw some peddler or gas man, PG\&E man, or whatnot, she'd just keep on writing. She could see them, but they couldn't see her.

It was just a little wooden place, as I recall, about twelve by twelve. She had her writing in there--papers all around her. And she had this heater, which was quite adequate for the space up there.

She saw somebody that she did want to talk to and she came down, and she talked to him for a long time. Then they made tea and talked. After a couple of hours somebody shouted and here her place was going up in flames. It had all of her notes from the time she finished the Flowering Shrubs.

She had gone through, I think about two-thirds of her third book. And losing all that work really broke her up. She was never the same again. She lost all the notes that she had made on the ground in the Sierra.

I can sit down and write about manzanitas because I'm simply devoting myself to explicating why they are what they are and $I$ don't need any real purple prose in there. 
Roof: If you ever want purple prose, you get it best by walking on the seashore carrying a card, and then it comes to you very easily. Or walking along a Sierra stream.

Most of the color that attaches to her writing is colorful because it was made on the inspiration of the spur of the moment. This is what she could not reproduce. She could reproduce all of her travels. She could reproduce the names of the flowers and where they were, and all that, but she had lost so much of the really beautiful writing, what we'd have to call belles lettres-she had lost that.

I said, "Lester, I have enormous amounts of material. Just take it." It was a silly thing to do because I didn't realize at the time what she really had lost. In her field notes, were all of the happy thoughts that she had thought along the trails. Not what she could synthesize in that cabin, but those felicitous phrases that are the things that really make her work--all gone.

Levenson: What she called her "helps."

Roof: I said, "You can have all my notes--anything you want--to get started again." "Oh no," she said, "I can't do it." After a while, she broke down and cried. That was the only time I ever saw her really upset. I don't think she did it with anyone else. Just said to them, "Win some, lose some"--that sort of attitude.

But it really hurt--it really cut her--put an end to her writing. She'd never write anything after that. Oh, maybe she'd dash off a page or two for the California Horticultural Journal, but that was nothing. She had really lost it all in that fire. She had planned a trilogy: The Flowers and Herbs, then The Woody Chaparral, and then I think trees.

She had photographed the trees up in the Sierra, and she had photographed twisted junipers and the Jeffrey pines at high elevations, and the trees in the highest mountains. She had it all there in that shack and lost everything. Lost all the photography. Had she known she was going to live to be a hundred, she might have tried it, but gosh, I don't know how old she was at that time. I think about eighty.

She could not overcome that. I don't know how she managed to live so long after that--it was such a tremendous jolt. She was just simply tired. The third book would be everything left over from the other two. Probably the best of her writing would have been in the third book.

Levenson: Was there ever any suspicion that it was arson? 
Roof: Oh, no, no, no--I know those damned oil heaters. I've never trusted them since, but I trusted them before. I've walked away from them and left them burning all night long.

I had a shack over in San Francisco in my back yard--I turned those oil heaters on in the winter. Kerosene was what--a nickel a gallon then? I'd just let it burn. The boys would come around and call me, "Hey, let's go play poker" or something. I'd go away and leave it--come back and the place would be warm. I never saw one get away, but that one had to get away!

They flare up around--they had a little window that showed through--a little isinglass window--you'd see the flame and if the flame got a little too high, you turned it down. Of course, what she should have done was put it out when she went down to talk to this person. She just rushed out and left it going. Disaster--that was utter disaster.

Her favorite country was timberline. She had notes on trees that grow in the highest part of the country. About my notes she said, "Oh, no, you don't have what I had." No one had what she had.

She Was a Loner

Roof: People wouldn't have thought that she was so close in character to [John] Muir. It's been neglected. No one's ever considered her from that point of view. You know, Muir is celebrated for having bought ten cents worth of raisins and a bag of tea, and for disappearing in the mountains for a whole summer and fall.

She did the same thing. She took a burro and took off into the mountains. She's absolutely the female John Muir. I hope that this is somehow brought out by the people writing about her. They don't parallel her with Muir because she's a woman. The big thing was that Muir got away with his writings and his shack didn't burn down.

She was the closest contemporary to Mulr. I was trying to think of a man who compares to Muir. I can't think of anyone. They have never compared her with Muir because she's a woman. She is exactly the counterpart of Mulr. She was a loner. 
Roof: Muir liked to take people into the mountains. Lester didn't. I think that might have been the biggest deal. When she went into the mountains, she was happy to stay alone on a trail somewhere. She didn't want you around. When she was camping, she wanted to be alone--she wanted her own thoughts with her. And I don't blame her. She wanted to have her own thoughts about her and she wanted to write when she wanted to. She wanted to get up real early in the morning and watch the sun rise without anyone jabbering in her ear.

Now, Muir was happy. He'd sit there and explain the whole sunrise to you--the way it came up, why it came up [chuckles], but not Lester. No, she was a loner. But, beyond that, they were cut out of the same cloth. I doubt that we'll see her like again on the Sierra trails.

There are so many young people now who just go. They go far and wide in the Sierra, but they don't write--they don't write like Lester. [Laughs] They write humorous things or they'11 write lines that'11 catch an editor's eye, or something like that. Or get them into the Sierra Club magazine. There's no one on the horizon that writes that way, either. They're a little too matterof-fact.

And the state was different then. The thing that Lester and I remember--I guess we have it in common--is that when you drove across the valley to Yosemite, you didn't get there in a day. You didn't get over the Tioga road in a day. You were lucky to get a car out in the middle of the valley, around Oakdale, or Oroville on the Feather River. It was hot out there--everyone remembered the first day of their trip. It was extremely hot and you always headed for some river, like the Stanislaus or the Feather, Mokelumne, Tuolumne, one of those rivers coming down out of the Sierra. Or the Sacramento, if you went north.

And she remembered that. You stopped out there in the valley where it was really hot, and you swam in the rivers. All the rivers were good water then. They're gone--they're all gone. The farmers have taken all the water out of them. And she remembers that.

Then the second day, you went up into the Sierra. If your car didn't break down, you got up into the transition forest, but not to the summit. It was three days to the top of Tioga Pass, generally, where you got into the high mountains. Or to her pack station, where she would get her burro, pack up her gear, leave her car, and take off into the mountains, and not come back for two or three months. She remembers that. 
Roof: Today the young people go up to Yosemite, and they go down the John Muir Trail, come out at Sequoia National Park--they've really done the tour, like the old European tour. They've done it. But what can they write about it? Not much--I haven't seen any sparks flying for a long time.

I can drive from here to Reno in about six hours, and I don't drive fast. I don't see anything along there that I used to see, along Highway 40. I used to stop up there and park on a turn-out of the road, take my friends and walk through some brush for a little distance--I don't know, several hundred yards--and there was a huge pool. They just praised that pool up and down. It was a great swimming pool, with granite rock all around it--and I can't even find it today. I can't even find it.

But these are the things Lester remembers. She remembers California as it was when there were only six million of us in the state and most of those were in Los Angeles--when there were huge fields of wild flowers to trample over and seed to collect. I think that this has been the thing that has bothered her most for the last twenty-five or thirty years.

Levenson: I certainly thank you. Shall I switch the tape recorder off now?

Roof: I think you can switch it off safely! 
1. The Rowans, Oradell, New Jersey, the Rowntrees' first home.

2. Lester Rowntree, commuter's wife.

3. The Rowans -Herbaceous Border as seen from the Pergola.

4. Bernard, Lester and Cedric Rowntree.

5. Cedric in school uniform.

6. Lester Rowntree, Lila Clevenger and dogs in Carmel, c. 1929 .
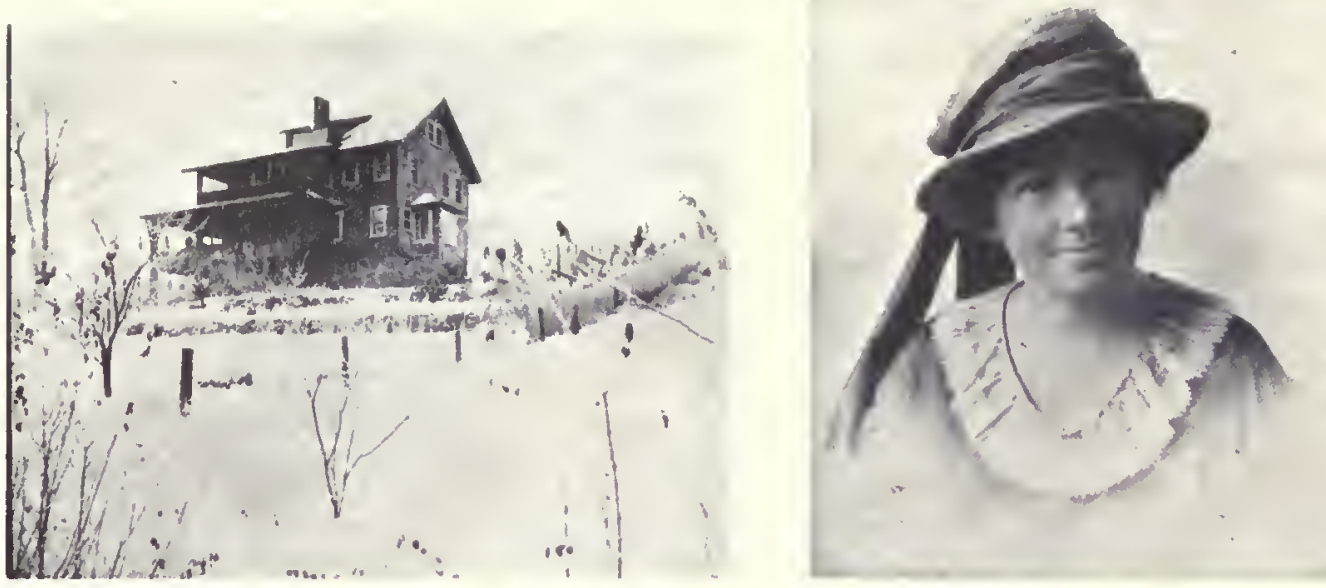

1 .
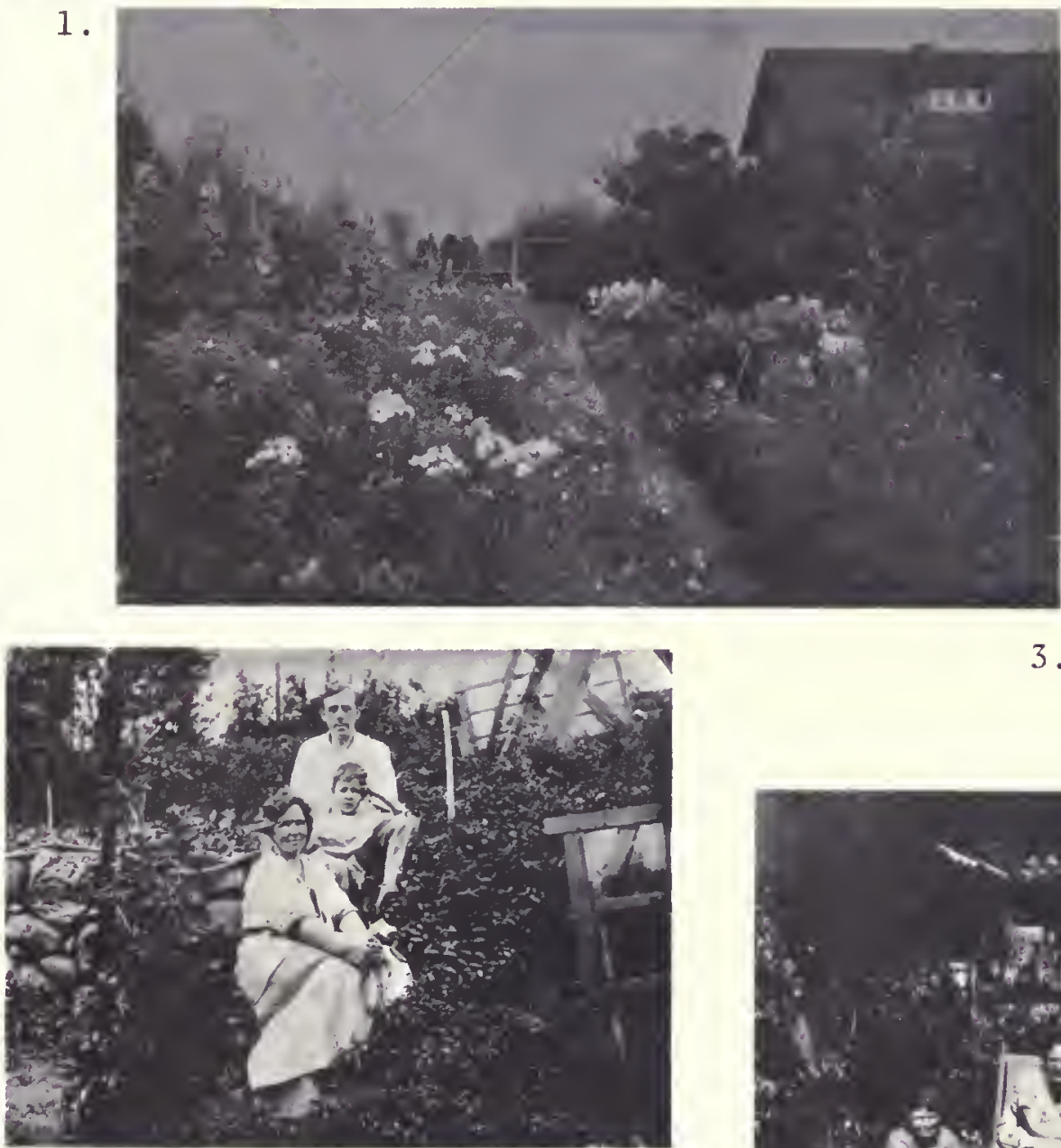

4.
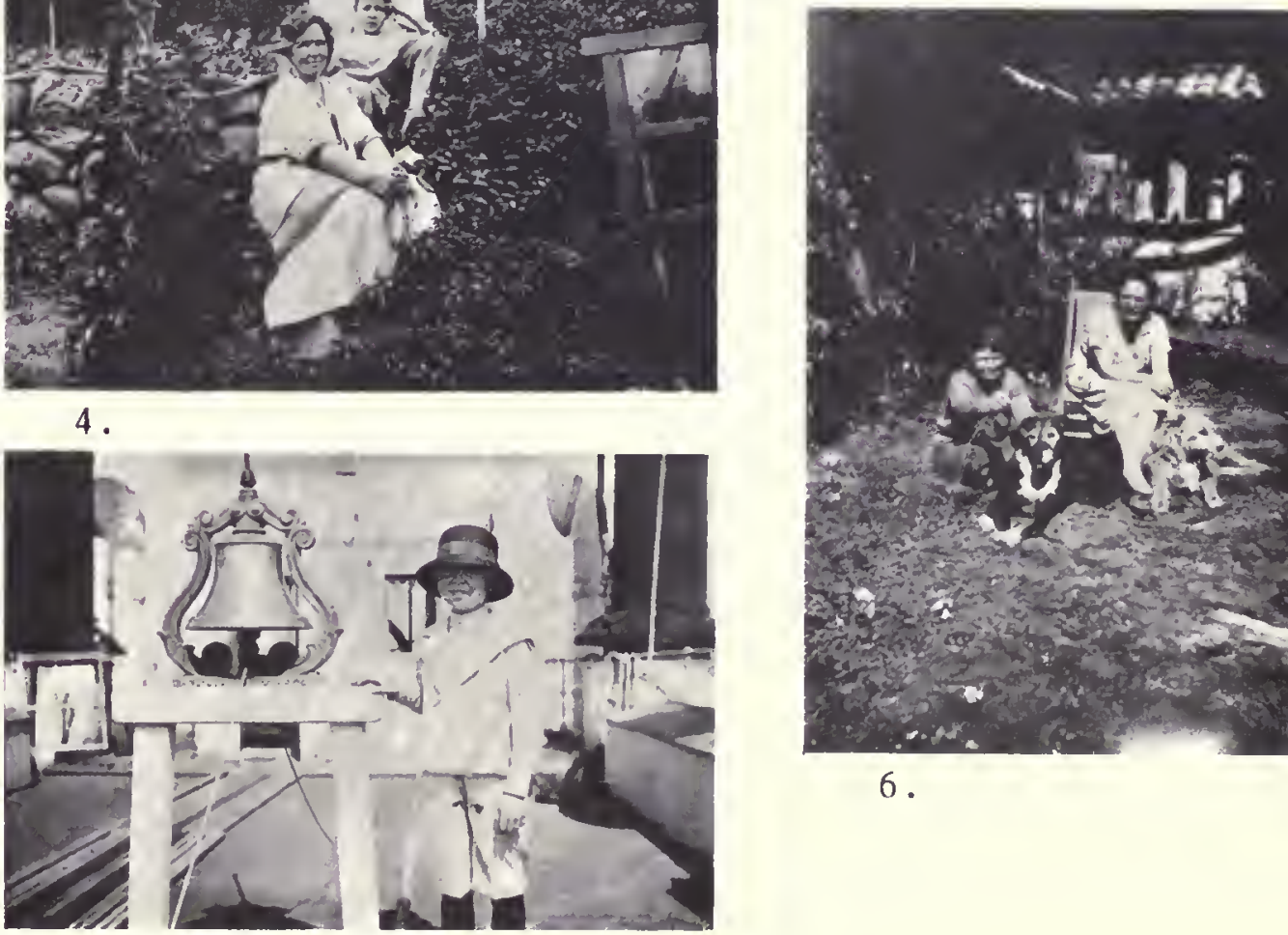

6.

5. 


\section{INTERVIEW NOTE}

\section{Lester Rowntree: Apothegms}

Lester Rowntree, as this volume vividly shows, was many things to many people and led a number of lives in her five score years. Not surprisingly, the role of Wise Woman or gum is dominant in this conversation held in her hundredth year, but an engaging strand of earthiness is ready to prick any balzoons of pomposity that threaten. "You mustn't get preachy. . . You mustn't get to talking like this too much--it's too goody-goody" (pp. 95-96).

Our first talk took place in May, 1978, in the upstairs apartment of her Carmel Highlands home, and was somewhat stilted. Lester was lying uncomfortably on a sofa and did not choose to move. No real ropport was established and the sound quality of the tope was too poor for transcription. Lester kept repeating that she really had nothing to say. It was a discouraging experience.

Shortly after that visit Lester fell, was hospitalized, taken to a nursing home, and then at her urgent request, brought back home to the ground floor apartment where her son, Cedric, and daughter-in-low, Harriette, felt that the risk of falizing was reduced.

In July, I returned with a tecon of three from the Educational Television office to shoot the row footage for a documentary. While they were setting up their equipment for the next day's shooting, I settled down peacefully in the late afternoon, out of doors with Lester. This time, I used a Nagra reel to reel recorder, and she and I both wore inconspicuous throat (Zavaliere) microphones.

The view was idyzzic. Way down below us, the Pacific Ocean could be seen and heard breaking against the rocky Carmel coastiine. As we talked the summer fog started to rolz in, and the evening bird choms began to rise. The fragrance of the native chaparral from the hill behind and the various native and introduced plants mixed their scents with a strong piney smell, bringing remembrances of my childhood in England and camping trips in the California mountains. Lester was lying on a chaise, welz wrapped up in a heavy blanket--apparently this was her preferred position whenever she was not actually hiking or gardening. Like Winston Churchizl, she functioned best on a sofa or in bed, writing, talking, listening to music or to people. 

Lester's mood was totally different than in May. As a later memoirist says, "She was so good." She was concermed for my comfort. She asked repeatedly, "Are you too cold? I can come in if you like." She wanted to talk and to respond. She cpologized when her memory failed. Her temper flashed up once or twice. She resented an unintended implication that she was a thrizl seeker. "I wasn't after adventures. If adventures happened my way, that was part of the game or the $2 i f e^{\prime \prime}(p .91)$. Lester's fire was dying down but the intensity of some of the flomes brought the younger Lesters I had only seen in photographs vividly alive.

As Lester tired and the cold and foggy air finally drove me inside, she rested for a littile while. Harriette brought down a delicious supper. Lester, able to walk unaided at that time, dashed to the table. This is not an exaggeration. Please see pages 229-230 for another such observation. She urged me to sit and talk with her as she ate. It was a delightful interiude! I watched Lester demolish a slippery piece of corn on the cob with pertinacity and gusto. She also enjoyed fish, custard, and juice. Again, Lester needed to rest.

The next day, we worked together on interviews for the documentary. Lester was worn out.

On my last day, I went down to say "good bye." On an impulse, I asked permission to kiss her. She tumed her face towards me, the skin was petal soft. She said, "So nice, so nice. Come again." I am glad that I did. 
Lester Sees Queen Victoria: A Child that was Seen and Heard

Levenson: Mrs. Rowntree, where were you borm?

Lester

Rowntree: Penrith.

Levenson: That's in the Lake District, isn't it?

L. Rowntree: Yes.

Leverson: Wordsworth country.

L. Rowntree: Yes. Yes. Yes. Wordsworth and his sister.

Mother Zoved Wordsworth. On Sunday afternoons--do you know what the beacon is? Beacon Hizz?

Levenson: Where they used to light the fires to send messages?

L. Rowntree: Yes. When there was a jubilee, we were alzowed to go up and see the fires lit. 
Levenson: That must have been Queen Victoria's Golden Jubilee?

L. Rountree: Yes, it was.

Levenson: Did you ever see the queen?

L. Rowntree: yes. Once. But it was bad because I was in sort of disgrace--I was the one member of the family who'd never seen the queen. Then there was word that her train was stopped in a station somewhere. Father said. "Her's a chance for Nellie"--that's what they called me--and he took me under his arm and took me up to the station and held me up at the window.

Here was this little black bundle, mourning like anything for her late, dead husband. She didn't pay any attention to me. I rapped on the window, and my father pulzed me down--oh, gave me such a scolding for attracting the attention of the nobility or the royalty, or whatever you call them!

Levenson: [Chuckles] Did she notice you?

L. Rowntree: Yes--she waved a little. I think she was pleased, but she was shocked. Children weren't supposed to do things like that! 
Cooks in the country

Levenson: I think you told me earlier about the picnics, only they weren't called pionics.

I. Rowntree: Cooks in the country.

Levenson: Cooks in the country. That must have been a big spread.

L. Rowntree: No, it wasn't really. It was just a big nome for a little thing. It was nice because--oh, not so much for the food--but we'd make little houses in the bracken, in the ferm you know--

Leverson: Yes.

I. Rowntree: We'd all make a ring around Father and Mother, who were in a little bracken house in the midale, and Mother would recite Wordsworth and Father would recite Tennyson. Tennyson isn't such a good poet. Wordsworth was good, and I'm glad we had that.

Levenson: It sounds like paradise.

L. Rowntree: Mrm. Mrm.

Mother was a heroine. Father just wanted a brood mare, good breeding stock. 
1) 1370 $3+10$

s.

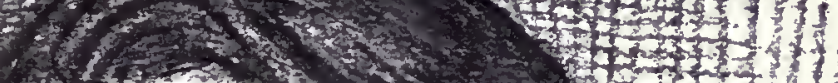

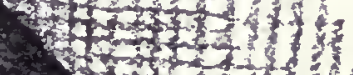

int $1+1$

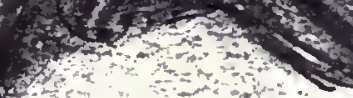
$+7, x+2$

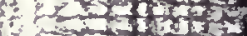

atom

int

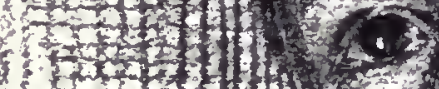

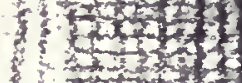

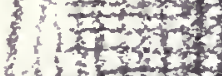

$+150$

- 30 (1)

$x+\frac{x}{2}$

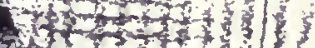
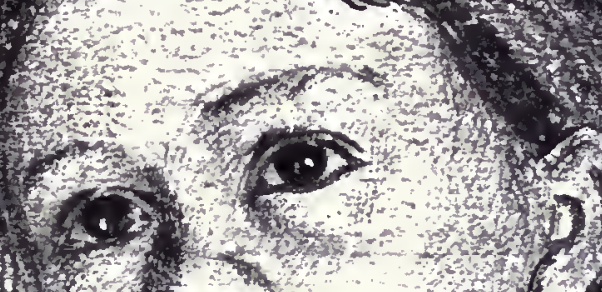

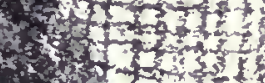
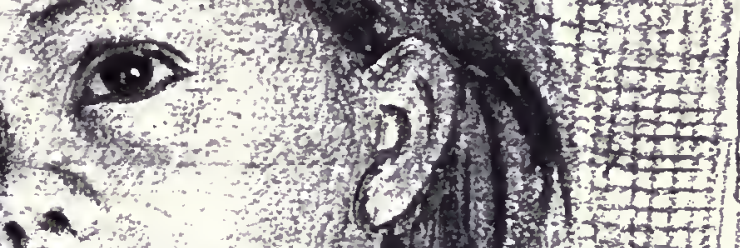

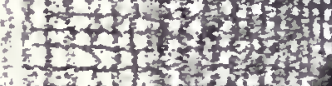

W.
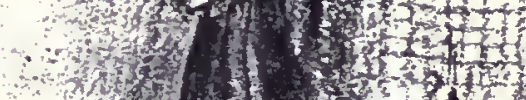

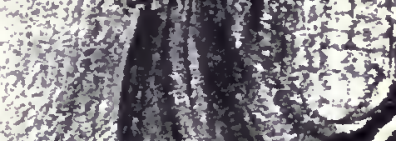

II)

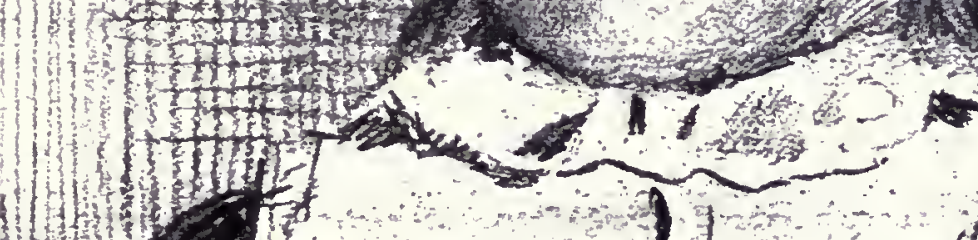

MW W

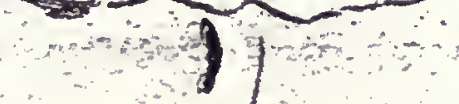

$7 e t 193$
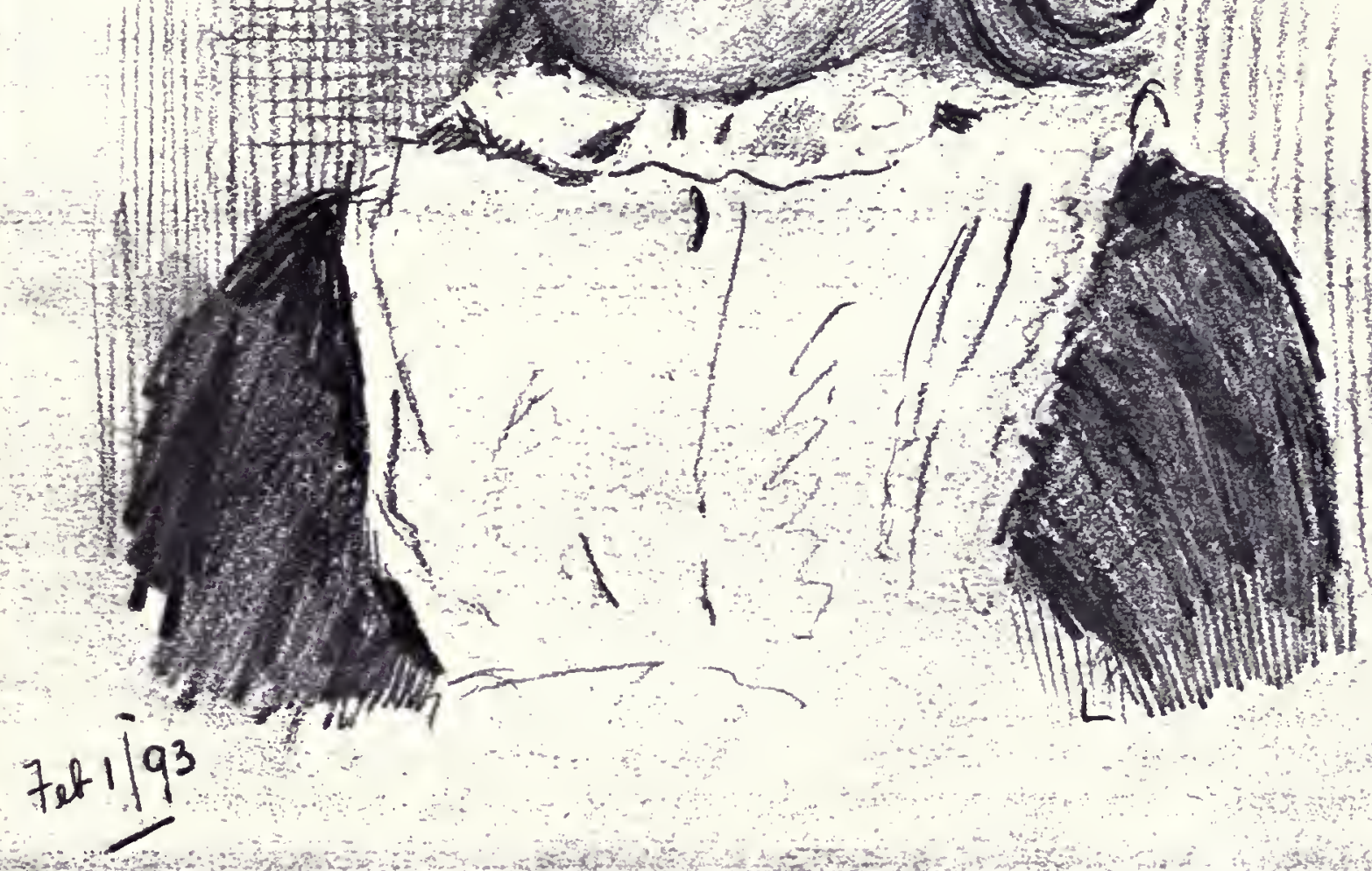



\section{Homesickness is a Good Thing for Anybocy}

Levenson: You were sent off to a Quaker school, I believe, to stop you being such a mincway?

I. Rowntree: Yes. I was sent East [from Califormia] and didn't get home until the long vacation--sometimes I dian't get home for a year. I was so homesick-oh, so homesick--but you know, I think homesickness is a good thing for anybody.

Levenson: Why?

L. Rowntree: Got to learn to stand on your own feet.

Levenson: Then, when you got married, where did you live?

L. Rowntree: I Zived in the East--I was a proper commuter's wife. They used to call me "the running bride" because I ran to the station every morning with my husband, and then ran back, for exercise.

Levenson: That's wonderful! That's come into fastion again. Everybody's muring now. You set--as you did in so many things--you set the fashion.

L. Rowntree: Oh weil, I didn't know it then.

Levenson: I believe you built a beautiful garden at the Rowans. [Oradeiz, New Jersey] 
L. Rowntree: I did. I did. I did. Big driveway and drive--the gates of the driveway, once a week, were opened, and I let conybody come who wanted to and look at the garden. I'd stay in the house--look out the winciow at the crowds who came.

Levenson: What were your great favorites in that garden?

I. Rowntree: I think the rock garden--full of blossom.

Levenson: You wam against plants that take over the rock gardens. One of the ceanothuses and some of the alyssums and lobelias. And you also wam against objects--figures in rock gardens.

L. Rowntree: Oh, yes--those silly little things. A man came to me who lived in the Rowans after I come out here. He said, "I just wanted to see what sort of person you were. Promise to come to see me when you get East again, and see what I've done to the rock garden." And I did. I spent a night there and he put a lighthouse in the garden--oh, it spoiled everything.

Leverson: A Zighthouse!

L. Rowntree: AII the character of a natural rock garden was gone. It's all right. They have to go through periods of real and unreal, you know. 
Levenson: And your son, Cedric, did he go cavay to school, too?

L. Rowntree: Yes, but he wasn't in Westtown long enough to get the real [Quaker] message, and he wasn't the same material.

My husband was an engineer and they're very different things.

I wasn't fair to my husband. I've always wanted to apologize to him.

Levenson: In what way were you not fair?

L. Rowntree: Because I think I'm rigid. Physically, I didn't give enough--I'm not sexy enough.

Change is a good thing. There always will be change--change, change--for the good or the bad.

Levenson: Westtown was a Quaker schoor, wasn't it?

L. Rowntree: Yes.

Levenson: What have you kept out of your teachings from Westtown--from the Quaker teachings?

L. Rowntree: Love of nature, I think--for the good of a place-and then it's all right to min cavay--take long walks all alone-- 
Levenson: You ran aiday?

L. Rowntree: Yes. It's always paid off.

Leverson: In what way did it pay off?

L. Rowrtree: Oh, the joy you got of being alone and out--way out-it was lovely country.

Levenson: That's in Penrsylvaria, isn't it? Westtown.

L. Rowntree: Yes.

Otters, Beavers, Sheep, and Mules

Levensor: And did you swim?

L. Rowrtree: Not then--I'm a very good swimmer now. It certainiy, I think, is one of the best of exercises.

Levenson: I hear you used to go swiming with the sea otters down below here.

L. Rowntree: Every morning before breakfast.

Levenson: Did you walk down and back up?

L. Rowntree: No, I drove down. 
Levenson: But the water's so cold, isn't it?

L. Rowntree: Well, that's why I did it, becuase I wanted to get hardened off. I never caught cold. I never had a cold. People get so soft, you see.

Levenson: You're right.

Do you think that the sea otters enjoyed your compary? Did they notice you?

L. Rowntree: They were curious and they'd get on top of a wave and take a peek at me--on top of conother wave-down--then they'd go down and think, "What was that thing up there in our waters?" And they'd come up and take another peek--then they'd go down again. They're nice, forgiving things.

Levenson: They're beautiful and funny.

L. Rowntree: And then there's another animal in the waters, very unhospitable. When they're mad, they go bang with their tails on the water--do you know what I mean? Beavers?

Levenson: Oh yes, beavers do that, don't they?

L. Rowntree: Yes. They used to share their ponds with me, and I used to--but I mustn't get too near the edge where they're going and have their homes. If I 
L. Rowntree: got too near the edge, bang! their tails yould go doon. He's saying his house is out of bounds.

Levenson: That's what we used to say in England, at games, "out of bounds."

L. Rowntree: England's nice. Are you going back?

Levenson: I hope to next year to see my brother and his sheep farm.

I. Rowntree: Sheep are sort of dumb, aren't they?

Levenson: I can't see the attraction, but my brother's very fond of them!

L. Rowntree: Oh well, you're borm loving sheep or else not loving sineep.

Levenson: Talking about big animals like that, I sai some lovely pictures of you with your burro and some with ponies. Where did you leam to pack conimals so well for jour pack trips in the Sierra?

L. Rowntree: I didn't pack very well. ing rolls were sometimes skidding off the mules. I suppose mules helped me. Tiney're not so dumb as you think--they're just stubborm.

Levenson: Yes. 
Adventures iust Happen

Levenson: I know that E.D. Rowe was a great friend of yours, wasn't he? Purissima Mission.

L. Rowntree: Yes, he was pretty good. I didn't know him very wel2. Used to come to me for advice, but he knew more than I did.

Levenson: Did you help him collect the flowers for the various missions-- the native plants?

L. Rowntree: Yes, a little bit.

Levenson: Did you have some adventures doing that?

L. Rowntree: I wasn't after adventures. If adventures happened $m$ way, that was just part of the gome or the iife. [Crossty]

Leverson: Yes, I understand that. I'm sormy--I didn't quite know--

L. Rowntree: That's all right. It just happened.

Levenson: What hoppened? 
L. Rowntree: Adventures--you don't go after them--they happen. Sometimes they're nice; sometimes they're not. You meet nice people--nudists, for instance. Colonies of rudists were nice people.

Levenson: When was this, or where?

I. Rowntree: When I was doing field work--and all over. Nudists are nice people--they reverence their bodies.

Levensor: That is something, I think, that people are coming to recognize more--the reverence for nature.

L. Rowntree: Yes. Nothing like it. Mother Earth. [Softly] Are you cold out here?

Levenson: I'm fine, thank you. I love it.

L. Rowrtree: Because you mustn't get cold. You see, I'm all bundled up, and you're not.

Levenson: Are you comfortable?

I. Rowntree: Yes, thank you. I'Il go in if you want to, or else if you're uncomfortable.

Levenson: I see a huming bird. I think it's an Anna's humoming bird--down there. 
L. Rowntree: It's about the only one we've got. They're rather cumb birds.

Levenson: Why do you call them dromb?

L. Rowrtree: Because once, when I went to--I was doing field work on the desert--you know, the desert's full of hidden valleys. They're just called hidden valleys-they're not really hidden.

But there was one you could get into if you were hungry. But if you had a big meal, when you're inside you couldn't get out--if you ate too much. I've forgotten what--what was I going to say?

Levenson: About the hrming bird?

L. Fowntree: Yes, yes. Omithologists won't believe this--but I was in a place where there were no little twigs of things to make nests of. I got into one of these hidden valleys and I felt a presence. You know, if you're out a lot, you can feel presences.

I looked down and there was a hwoming bird's nest, made out of clay. Well, huming birds don't make nests out of clay--but this was out of clay. And there were two little babies in it. of course, they didn't last long--something ate them. It was a dumb thing to do, anyway. 
Levenson: Were you ever in a flash flood in the desert?

L. Rowntree: A flash flood?

Levenson: Yes.

L. Rowntree: Yes. I was with someone once and I'd rather have been alone. I'm a zoner, you know.

Levenson: I know.

L. Rowrtree: A flash flood came on, and she said, "We've got to get out of here!" I said, "Wo, stay here and see it-enjoy it and move up with it." It got more and more, and we had to move up the sides of the canyon to keep out of it. It was alz right. There's always an end to our troubles.

Leverson: That's a very good phizosophy. I have a neighbor who says, "Nothing is ever really lost."

I. Rountree: Yes, and you must never be afraid of anything-nothing.

Levenson: How did you Zeam that?

L. Rowntree: Well, I just became that way. 


\section{You Mustn't Get Preachy}

I. Rowntree: You've got it innate in you--you must never be afraid-you're born with it really, but you lose it too soon.

Levenson: Wordsworth said something about that. He said,

The youth who daily farther from the east lust traver, stizl is Nature's priest, And by the vision splendid

Is on his way attended.

L. Rowntree: Yes, yes, yes. Wordsworth was good.

Levenson: How did you keep the vision alive in your son and your grondchizdren?

L. Rowntree: I never tried. You mustr't get preachy. [Laughter]

Levenson: That's so true!

L. Rowntree: Rules out what you're trying to do. It's no good.

Levenson: I wish I'd had the opportunity to go on one of your trips, but you were a Zoner.

L. Rowntree: I was a Zoner.

People aren't tmuthful. People should be more tmithfur. 
Levenson: How do you bring that about?

L. Rountree: Just by being, experiencing that Iying doesn't pay. Not coing it because it doesn't pay, but because it isr.'t right.

You mustn't get to talking like this too much-it's too goody-goody.

Leverson: [Laughingly] Yes.

I. Rowntree: You can't do truth this way. You've got to be alone ana you've got to have all your pores open to nature-to the real things--not just things that are supposed to be civizized.

Levenson: I think we're getting back to that a little bit--I hope so.

Camel Highlands: "Buizd Here, Buizd Here"

Levenson: How did you come to choose to live in the Carmel Highlands? It's like a paradise now, but it was so bare, wasn't it, when you first come here? 
I. Rowntree: Yes. Ours was the second house, I think--the Ingalls first, and then we had a big house. After the divorce I had a tiny little house--I was very poor-I was doing field work and I work by my intuition and I have to listen to my intuition--it always turns out well--it never lets me down.

I came up over those hills, back here, and when I got to this flat place--here where my house is--my intuition said, "Build here. Build here." Well, I didn't have any money. I said, "All right, give me time." And it happened all right.

Levenson: Is this where you tried out many of your native plants for the seed business?

I. Rowntree: No, I never grew them for the seed business. I grew them for pleasure. Anything I sold, I got when I was out collecting.

Levenson: I read part of your manuscript on rock gardens. Did you test some of your plants here so that you could write about how they actually did in your garden?

I. Rowntree: No, I never did it so I could write about a thing. I wrote about things that have happened.

Levenson: It smells so beautiful here.

How did you get the idea to collect the kelp to build up your compost, your soil here--see, I'm saying "soil," not dirt. I'll never say dirt again! 
L. Rowntree: No, no--don't.

Well, that was bad business because I didn't know you weren't supposed to take arything from the beach. I knew that secaweed was a very good thing for compost. I kept pulling it up and pulling it up, and cleaning up the beach, you know--it'd get rolled up and make unsightly piles on the beach, and I'd go and get them.

Then once, a ranger was up at the house talking and I showed him how I'd been heipirg him clean his beach by collecting the secweed. He said, "You mustn't take one thing. There's a mile: you mustn't take one thing from the beach--not a pebble or a sheli, or anything." So, that put me in my place.

I didn't know whether it was right I should have told him--or I should have hidden it--I don't know which I should hove done?

Leverson: What do you think now?

I. Powntree: I think I should have told him.

Levenson: That sounds right to me.

L. Rowntree: But after that I didn't take anything from the beach. 


\section{The Ouzer is my Favorite Bird}

Levenson: I read in your books and your manuscripts about all your travels from the South, from the desert on North and up higher and higher. What were some of your favorite places on your seed-collecting trips?

L. Rowntree: Do you know the Santa Barbara Garder Magazine?

Levenson: Yes, I've seen some copies of it.

I. Rowntree: The most real stuff I wrote was for that--not paid.

Leverson: Wris was it the most real?

L. Rowntree: It was from the heart.

Levenson: I had the feeling from what I've read of your writings, that the Sierra was your favorite place.

L. Rowntree: Oh, yes. [Dreamizy] It does something to you. I used to go across on one of the passes and then up on the other side and then back on another pass, and do them air, each summer. Ebbetts was nice.

Levenson: You talk of the flowers coming out from under the snow. 
L. Rowntree: Mrm. Yes, you'd see them come alive and come open from the buds. The buds were way back in--You see, snow above made it light back there--If you stay there long enough and sleep there, then you see them develop. you see it all happen. Nice--nice.

Levenson: You write about the rosy finches way up, twelve, fourteen thousand feet--the little birds.

L. Rowntree: The rosy finches?

Leverson: Yes.

I. Rowntree: Picking the irsects off the snow drifts.

The ouzel is my favorite bird. Its song.

There'd be a mushing river and then a rock coming out of it, in the midale of the river, and the ouzel would sit on the rock and try to sing louder than the river. Nice bird--some nice things have been written about it.

Levenson: There are some nice things in your children's books.

L. Rowntree: My children's books were just potboilers. They're true, but they were written for a wrong purpose-because I had to have money. 
Levenson: Wher you wrote the last one, was there something about your own accident in it--when Denny loses his sight as a result of a fall in the mountains--in the desert?

L. Rowntree: I don't remember.

Levenson: And he manages to write vith a mile in hospital.

L. Rowntree: Oh yes. I remember in the hospital, having to write with a rule to keep the lines. I don't remember anything else. But it was alz so, anyway.

Leverson: You talk about sincerity.

L. Rowntree: Mrm. Mrm. So important and so rare. There must be some sifting process that sifts the sincere from the phony.

Levenson: How does it work, I wonder?

L. Rowrtree: It works because it is. It has to be. Iruth's got to come out somehow, somewhere.

Levenson: You must hove had a hard time explaining the truth sometimes, as you drove through these country places with your flower presses and your piles of old newspaper.

L. Rowntree: Oh, I didn't try to explain. They just thought I was phony. 
Levenson: Phony?!

L. Rowntree: Yes.

Levenson: Really?!

L. Rowntree: Yes. Have you read any of [Bermara] Jepson?

Levenson: On, yes.

I. Rountree: Once, I was in a place--

[brief intermption by video crew member]

Levenson: You were saying about Jepson. Did he think you were a pirony?

I. Rowntree: Oin, no--but they thought he was a phony--and he felt they thought I was a phony. Once in a while. our paths would cross, and a few people I sow would see my press, you know. They'd scy, "Do you remember, there was a man here before--phony man with a press." only they didn't know it was a press.

Ievenson: Do you think that was because they couldn't understand a grown mon spending his time collecting flowers, or why was that, do you think?

L. Rowntree: Yes. They thought it was a silly thing to do. They lived with the flowers and they thought flowers were nothing special. It's the way it should be. I think it was part of a whole--

[ brief intermution as dog barks into microphone] 
1. The Rowntrees' first house in Carmel. "I lost this house." L.R.

2. House on The Hill, Carmel Highlands, 1936.

3. The rock garden.

4. Lester Rowntree in garden, 1934.

5. Lester Rowntree, 1931, aged 51.

\section{Lester Rowntree} at Bass Lake, 1940.

7. Lester Rowntree, 1926. "Nellie for years has refused to be photographed, but I got this of her without her knowing it, -- in my garden. It looks natural, she's the picture of health and activity." $\mathrm{F}$ (rank Lester)

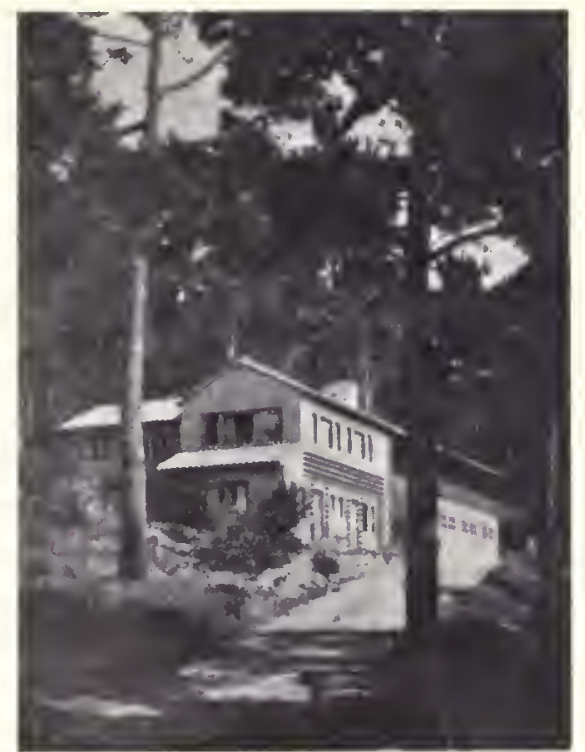

1.

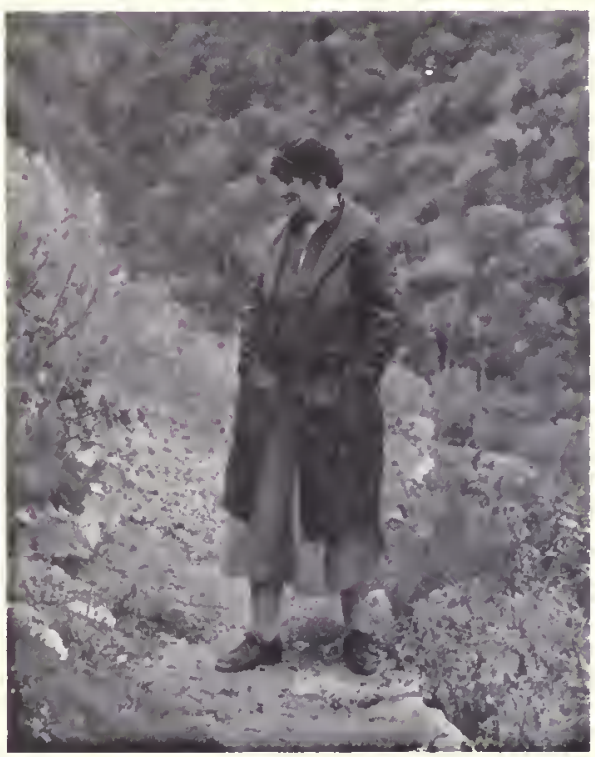

4.

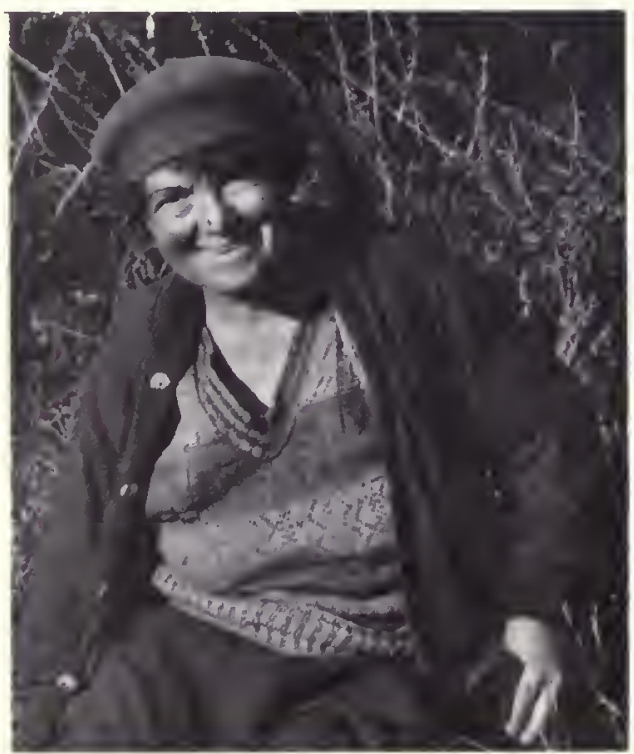

5.

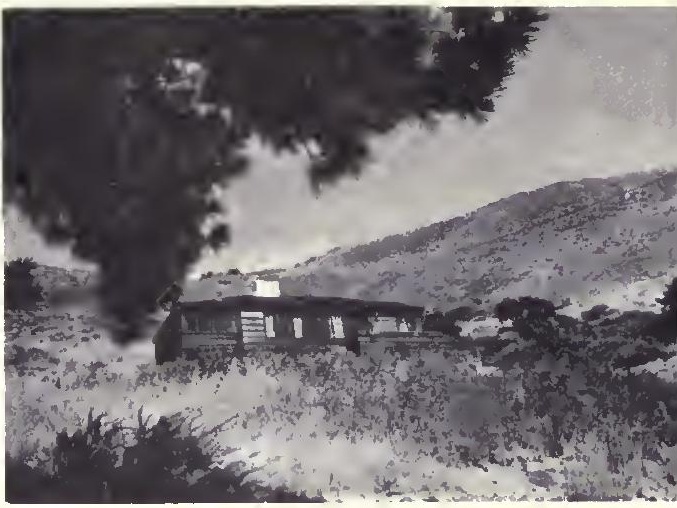

2.
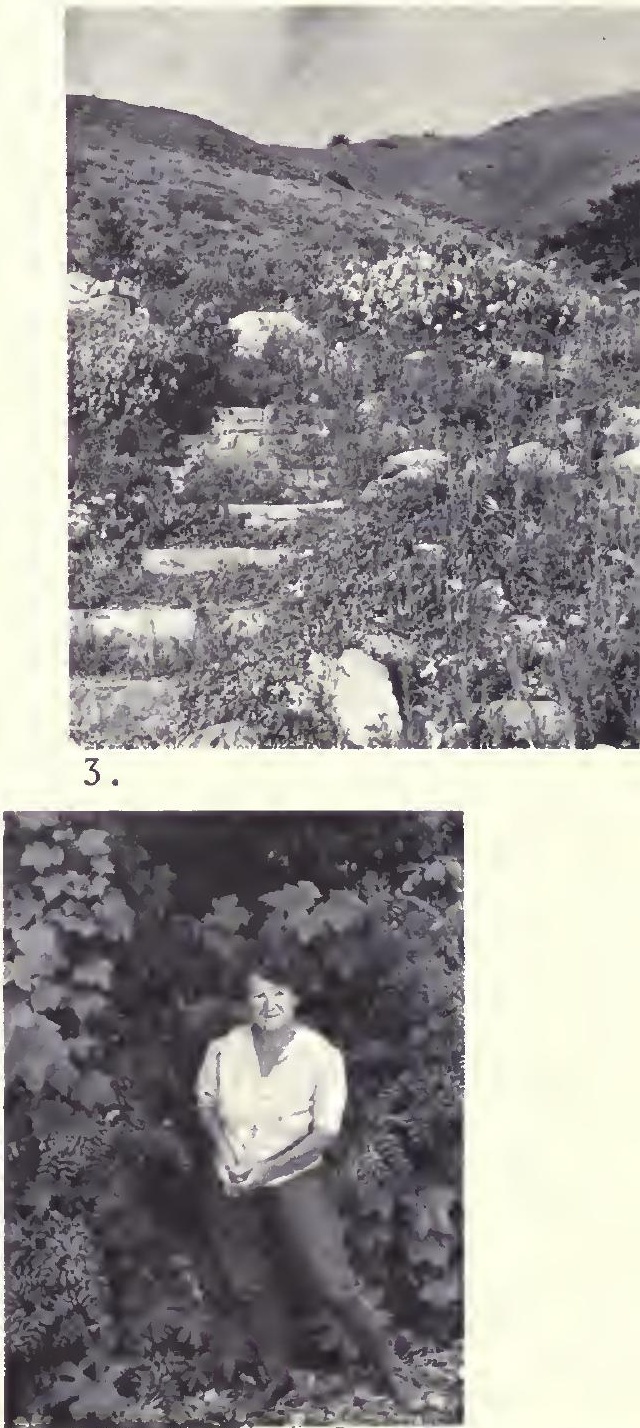

6.

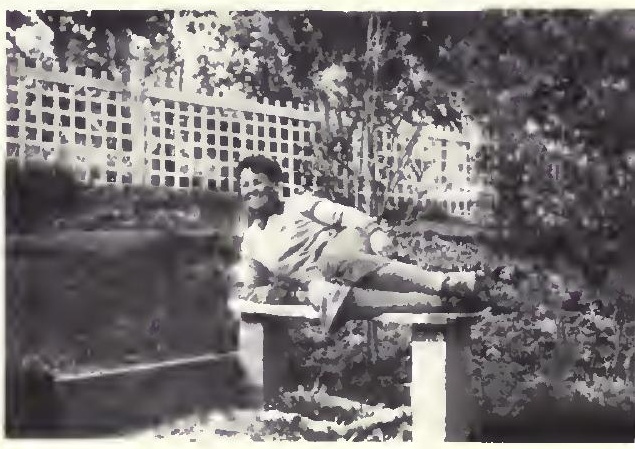



Levenson: The dog's off chasing somebody.

You know, Mrs. Rountree, I con getting a little chizzy.

L. Rowntree: Yes, well, you mustn't get cold. You see, I'm bundled up and you're not.

Levenson: $\quad$ You're very kind.

L. Rowntree: So, you must go in.

Levenson: Thank you.

L. Rowntree: I'ZZ go in too if you want me to.

Levenson: Whatever makes you comfortable.

I. Rowntree: I like to be out here, and I never mind being alone. 
INTERVIEW NOTE

The following six interviews with members of Lester's family form an extraordinary tapestry of feelings and recollections about a woman who was both in revolt against the family while being passionately devoted to it. Somehow comparisons of Lester with Queen Victoria do not seem out of place. Both were able to command and receive obedience. Both, at times, were criticized and adored by their families. Both seemed as though they would never die. Their brief encounter ( $p .83$ ) is a reminder of Lester's remarkable age and what it means, not just in terms of macro historical events, but also in the context of family histories and the history of the family.

Cedric and Harriette were interviewed July 11-14 during the three day visit of the television crew and interviewer. They bore the invasion with grace and were unfailingly generous with time, information, and refreshments.

\section{Cedric Rowntree: Lester Rowntree: Her Son's Perspective}

The interview with Cedric was started on the evening of July 11 in the upstairs living room after dinner. A blazing fire took the last feelings of fog-induced chill away, and Cedric, Harriette, and I settled down with an agenda to talk about Cedric's relationship with Lester. The first interruption came as old photograph albums were taken out and searched through for the picture that exactly supported a point. Then, as husband and wife started talking with each other (pp. 114-115), the interviewer realized that it was time to drive back to Asilomar to bed.

Two mornings later, we picked up the agenda again. Cedric spoke with some reserve about the difficulties of living with his father after the divorce while working part time for his mother, and openly about the problems of living or not living with an aging parent.

After transcribing and light editing, the interview was returned to Cedric who made very few changes. It was then final typed and indexed. 


\section{LESTER ROINITREE: HER SON'S PERSPECTIVE Cedric Rowntree}

\section{A Conscientious Mother and Father}

Levenson: It's a tough question to ask and a tough question to answer: what sort of a mother was Lester to you?

Cedric

Rowntree: I figured that was coming up sooner or later! As you said, it's a tough one to answer because what have I got to measure it against? I would say, to use words with open-end interpretations, that she was a good mother, that she was very concerned with my well-being, education, so forth. I just can't really say anything negative. I'm not going to hold it against her for not being around all the time when I was growing up, because I don't think that hurt me one tiny bit. When she was around, why, she was very concerned. She was not too lenient; at the same time, not what I would call strict. So you see, it's just a matter of beating around the bush, in answering that question.

By and large, I consider she's as good a mother as anybody could have. I was never close to my parents, neither one of them. I think that sums it up. I was never close to them like my kids are close to me and many kids are close to their parents.

Harriette

Rownt ree :

Don't you think that that was partly because of their own upbringing? They were both--

C. Rowntree: I don't know.

H. Rowntree: --brought up in an unemotional way, in the strict Quaker way of not showing your feelings.

C. Rowntree: They went out of their way to do everything possible for me. I know my dad did. He went out of his way to be with me all the time he could when he was home. I mean when I was really young. 
H. Rowntree: That's right. And they cared--they both cared a lot about him. They really did. But they weren't an effusive family. Mr. Rowntree scared me to death when I first met him.

Levenson: What was he like? He's a shadowy figure to me in all of this.

H. Rowntree: He was very awesome--a very difficult person to get acquainted with. Very terse in his manner of speaking. Not a warm or outgoing person, at least not in the first years. Later, he loosened up considerably. I met him shortly after the divorce when he was still frozen, and shocked, and poor, and struggling to get back on his feet from the divorce. He lost everything to the divorce. He was left with nothing, and he had to start all over again.

Levenson: He was an engineer, wasn't he?

H. Rowntree: He was with the Otis Elevator Company in New York. He left that business to come to California at Lester's request. At least this is what I was told. He never got back into business again because the Depression came.

Levenson: How did he live?

C. Rowntree: He took a salesman's job. That's the most recent one that I can come across. [Looking through photos]

Where's the one in the big hat? That's it--that's the most recent one right there.

H. Rowntree: Yes, but that was after he became a human being. [Levenson laughs.] No, he really did. There was all the difference in the world in the man.

Levenson: What changed him?

C. Rowntree: Grandchildren, maybe.

H. Rowntree: Having grandchildren, number one. But the thing that changed him was the association with other men in the community. He was elected to the Carmel City Council, and he was re-elected. He served eight years, didn't he?

C. Rowntree: At least.

H. Rowntree: He had a chance then--he always told me that he was never allowed to spend any weekends in golf with his business associates. He always had to work in this garden. 
Levenson: Cedric, what were your feelings about gardening when you were young, and how do you feel about it now? I gather Lester made you and the grandsons work pretty hard.

C. Rowntree: My feeling then was that it was just a lot of damn work. of course, now at my own speed and at my own direction, I like gardening pretty well. I guess that just sums it up. I like gardening, but I don't enjoy working when I have something else on my mind, or something else I'd rather do.

And, well, you know things fade away. Memory. I probably thought I was being used. I was being compensated. Two things that would stand out in my mind are picking up stones and weeding. I was paid by the bucket, five cents a bucket or something. I was getting a fair shake when I was small. I don't think it bothered me a great deal working around and puttering there.

H. Rowntree: It did in high school.

C. Rowntree: Oh, out here!

H. Rowntree: Yes.

C. Rowntree: We1l, out here, it bothered me some. My dad and I cut firewood. The only heat in the house was firewood, so we felled our trees--cut up firewood on weekends.

You're probably thinking about the house cleaning--

H. Rowntree: I am thinking of the house cleaning. I'm thinking of what you told me about you never having any Saturdays when you could go to games and things.

C. Rowntree: Go and lie on the beach. I don't think that's quite true.

H. Rowntree: That's why you never would lift your finger to help me in the house, because you had it up to here at home.

C. Rowntree: That's not quite true, because I did go to the football games on Saturday afternoon.

H. Rowntree: After you finished your work, sure. All right.

C. Rowntrec: I did have a horse, and I had a chance to ride, so things weren't all that bad!

H. Rowntree: They fade after you get older, but I can remember how Cedric used to tell me, "I don't ever want to live in a house with a garden on the side of the hill. I've just had it!" [Laughter] 
C. Rowntree: Yes. Here I am.

H. Rowntree: Here he is.

C. Rowntree: I know I said that.

H. Rowntree: You said it very strongly, over and over and over.

Levenson: How old were you when your parents were divorced? [1931]

C. Rowntree: I was just twenty, just twenty. Although they'd been working up to it--but as the saying goes, they postponed it until the right moment. I was finishing high school, they were communicating by notes for probably a year before--

H. Rowntree: Lester told me ten years.

C. Rowntree: Ten years?

H. Rowntree: She said they didn't speak to each other for ten years--except in front of Cedric, which--

C. Rowntree: We1l, that could be.

H. Rowntree: It's hard to believe.

C. Rowntree: I was very naive. I didn't realize what was going on until the last year.

H. Rowntree: Well, I can't understand their building that house together, if that was the case.

C. Rowntree: That's right. That's hard to understand, if things were that bad.

H. Rowntree: I think she was exaggerating, I really do. I don't think they were in that bad shape in 1926; I can't think they were in that kind of shape.

Theosophical and Quaker Boarding Schools

Levenson: Did your mother send you to boarding school?

C. Rowntree: Oh yes, she was always trying that.

Levenson: How do you mean? 


\section{H. Rowntree: Three times! [Laughs]}

Levenson: Oh, really?

C. Rowntree: The first time, when we lived in the East, she got on this Theosophical kick in the Theosophical school at Pt. Loma in San Diego at which her brother-in-law worked--

H. Rowntree: He taught there.

C. Rowntree: She sent me out there for a year.

H. Rowntree: Cedric was ten years old.

C. Rowntree: A tender age--that's these pictures on the beach here.

Levenson: Oh, that's delightful.

H. Rowntree: He ran away three times.

C. Rowntree: I guess, just after that, when we were in New Jersey. I went to a boarding school in Pennsylvania for a year. That wasn't so bad because it was fairly close to home. When I got sick, why, my mother could come down there. One time I jumped off a fence and cut my knee open. Another time, I had something else--

H. Kowntree: Measles.

C. Rowntree: Measles, yes. That's right, I closed the school for a while.

Levenson: How do you mean?

C. Rowntree: I exposed everybody to measles. They decided it would be better to send them all home where they could get the measles, rather than in school.

H. Rowntree: She had to go down and nurse you.

C. Rowntree: Then the third time, after we were here, the school year of 1929-'30, she arranged for me to go back to the boarding school.

H. Rowntree: At Westtown.

C. Rowntree: I was having a slow time getting through the local [Monterey] high school. She thought this would improve my ability to get through high school by sending me back there with a little more control over study. That, of course, wasn't bad because I was old enough to be able to turn things around so that I could 
C. Rowntree: enjoy them very we11. After the school year, I worked my way home on a ship. I had the option of going back, but I really didn't want to. I preferred to go to the local high school.

H. Rowntree: Rosemary, I think that Lester tried very hard to be a good mother. If there was any fault, it's that she was too zealous. She tried too hard. I really think so. I think she was overconscientious. She wanted perfection. I think that sending this child off to Theosophical school at the age of ten, was a search for perfection--

C. Rowntree: Or at least improvement.

H. Rowntree: Improvement of some kind. But what the child really needed was to have stayed home with his father and mother. He suffered considerably, of course. But in England, of course, they send children to boarding school at eight!

C. Rowntree: I always was one to suffer from homesickness. Then I did things of my own volition. I went to Colorado one summer to work. They were all good experiences in that respect, and I'm glad I did them. They were good experiences.

\section{Importance of the Quaker Background}

Levenson: One of the things that is hard to arrive at is how important the Quaker religion was to your mother, in the past and currently. I understand that when she was traveling with her seed collecting business and her lecturing, to some extent she used the Quaker network. She could stay with Quakers, she could go to Meeting and so on.

C. Rowntree: I would say, by scale, it was most important to my mother and it was next most important to my father, least of all to me. They weren't so much concerned with attending Meeting as with keeping contact with the Society of Friends. By that I mean correspondence with Friends, maintaining their membership at a Meeting-I forgot the name of the one in Philadelphia, Sixteenth Street Meeting or something like that, where they maintained their membership because they'd been married there.

I would say that compared to many Quakers I've known, their dedication to the religion or their active participation in the religion, was very slight. But they certainly were proud of their birthright membership and, as I say, they were interested in keeping contact. 
C. Rowntree: I was never forced to go to Meeting aside from when I was in the boarding school. They went to Meeting very, very seldom. of course, they lived in areas where there was probably not a Meeting such as Oradell. I don't know where the closest one was. When they lived in West Los Angeles, they could have gone to Meeting in Pasadena, for instance, which they didn't, as I recall. When they moved up here, I doubt if there was any Meeting on the peninsula at that time. There is now.

Levenson: Just to pick up on the speech thing, did you ever actually hear people using "Thee" and"Thou"?

C. Rowntree: We did at boarding school. It was not a hard and fast rule, but it was the custom at the boarding school. And I'm speaking about 1929, '30. When we had Friends visit us, they used it-the Balleys used it, the Walkers used it.

H. Rowntree: Always, always.

C. Rowntree: I tried to reciprocate in kind, but I don't believe in putting on a front. But it can come fairly natural to me if I'm among people who use "Thee"and"Thou."

H. Rowntree: It isn't used as much today, even among Quakers.

C. Rowntree: How do you determine that? Because we haven't been exposed lately.

H. Rowntree: Gene and Bill, when they're with us, never use it. Bill Taylor never does. And Howell never did. The last people that we were exposed to who used "Thee"and"Thou" consistently were the Bafleys, but they were of your mother's generation. The others I speak of are of our generation and have dropped it long since.

Levenson: Are you, yourself, of Quaker background, Harriette?

H. Rowntree: Well, yes! One of my ancestors was William Penn. I apparently descend from itinerant Methodist ministers [laughter]. My grandfather on my father's side was a Methodist minister, and a very strict one. His father also. On my mother's side, my grandfather was a cotton broker.

C. Rowntree: That's how come he married her for her money! 


\section{A Brief Stint at the University of California, Davis}

Levenson: Then where'd you go to college?

C. Rowntree: I started at U[niversity of] C[alifornia], Davis in animal husbandry, but I didn't last very long.

Levenson: Was that because of the Depression?

C. Rowntree: Partly, and because of my tendency to play more than work. [Laughter] I mean more than study. I worked on truck crops there to earn extra money. I was approached by a fraternity and made the mistake of pledging.

Levenson: Which one was that?

C. Rowntree: It was a local. It's called Phi Alpha Iota. So one thing led to another. I was just having too much fun to bother with studies. My dad could see the handwriting on the wall and he said, "That's enough of that. Come home and go to work." So I went to work with him in the real estate business.

Levenson: Down here in Carmel?

H. Rowntree: In the Depression.

C. Rowntree: That was just after my parents split, and he moved into town and my mother stayed in the house. I chose to move into town with him, which probably didn't set very well with my mother.

H. Rowntree: She was so upset over that.

Levenson: Was that about the time she started her serious seed collecting?

C. Rowntree: Well, yes, or perhaps a little after. She was doing a lot of trips while I was going to high school from the house here. Lila [Clevenger] was taking care of me. There were quite a few times when Mother was off on trips. 


\section{Lila Clevenger: An Unhappy Partnership}

Levenson: You were going to tell me about Lila Clevenger.

C. Rowntree: She was a part of our life. She didn't live with us in

New Jersey. She lived and worked in New York. But shortly after we moved to California--I was just trying to reason it out the other day. We spent our first year in Southern California-rented a house in West Los Angeles--then came to Carmel.

Levenson: About what year was this?

c. Rowntree: 1925. Then we came to Carmel, and rented a house for a year. That's when Miss Clevenger came to live with us.

The year that we rented a house in Carmel is the year in which my parents looked about for a place to buy: then they selected the property down the hill here, and had that large house built. I can't show it to you tonight, but during the daylight we can show you the larger house.

So Lila lived with us in Carmel from approximately 1926 to 1929. My parents split in 1931. There's a house at the end of the road here that Lila built--probably about 1929 or '30. She moved out of the big house up here.

Then, as Harriette indicated, she and my mother were in the wild flower seed business, and so forth, which went on from the early thirties until about 1946.

Levenson: What was the cause of the split?

C. Rowntree: Disagreement in business procedures and an audit that didn't show Miss Clevenger in too good a light.

Levenson: I think that there are a lot of things that are important about your mother, one of which is that she was a woman who made her way in an innovative career.

C. Rowntree: Certainly--

H. Rowntree: Oh, there's no question about that!

C. Rowntree: Those are the things we should be talking about.

H. Rowntree: Those are the things that are important. 
Levenson: Yes. But in addition, I think that there were problems that she encountered, because she was a wife and a mother and an untrained businesswoman. This is, I think, part of what you have been touching on. If there's anything that you feel that you can say that is honest and reveals some of the difficulties that she encountered--

H. Rowntree: I think the difficulties were in her innate honesty--

C. Rowntree: --and trust.

H. Rowntree: --and trust of other people. She was betrayed many, many times, but I also feel she was too quick to condemn and criticize. That that was a failing of hers.

She used to tell me how ashamed she was to take Lila anywhere. That she didn't like to include Lila because she was ashamed of her.

Levenson: Why?

H. Rowntree: Well, Lila was not a pretty person, to start with. She wore these heavy, heavy lenses. She was a well-educated person and a beautifully read person. She only had a high school education as far as I know, but she certainly was well read. But she was shy, and she was not pretty. Lester herself was accepted by everyone. You know the Lady Byng story?

Levenson: I've heard a little.

H. Rowntree: Lester took Lady Byng all over California with her chauffeur. They stayed in the best places and so forth. Lester has been entertained in England by really very high-class people. But she couldn't take Lila to these places. Lila would not have been accepted. At least, that was Lester's feeling.

Her own nephew said to me, when he came to visit, "You know, Aunt Gertrude's a terrible snob." [Laughter]

C. Rowntree: She didn't think any more of him, either.

H. Rowntree: Anyway, she certainly did have terrible problems in her relationships with her intimates. I don't think there was any question about that. What was she doing--having constantly to protect herself? Or what?

C. Rowntree: I'm not quite sure what area you're thinking about.

H. Rowntree: I'm thinking of her unhappiness with your father--how they parted with hatred. 
C. Rowntree: They did? That happens in many cases with divorce, dear.

H. Rowntree: And Lila, who was so close all those years--and to part with such absolute hatred.

C. Rowntree: You can understand that because my mother thought she'd been done in and that Lila had turned the tables on her somehow.

H. Rowntree: I suppose she never thought that she might have contributed--

C. Rowntree: What she thought about my father, I don't know. What their difficulty was, I don't know. It's very unfortunate that it ended up the way it did. I just feel that my mother is not one to go into partnership with anyone. I substantiate that by pointing out she and my father $d i d n ' t$ get along; she and Miss Clevenger didn't get along; she and the Balls didn't get along--the three partnerships that you can put your finger on. I would just say she's just not the type of individual to be in partnership with anyone.

Jobs and Marriage

Levenson: So, when you left college, you came to live with your father in Carmel?

C. Rowntree: That's right, I did. [Laughter] And you want to know what happened.

Levenson: That's right.

C. Rowntree: As far as my mother was concerned, I don't think a great deal happened because I was involved with living with him and working with him.

Levenson: In what business?

C. Rowntree: In real estate and insurance. I did come out here, let's see, yes--this place was being bullt, this house was being built at that time. We were very short of money, my father and $I$; we were very short of money. Once in a while, each one of us would do a little extracurricular work to try to bring in some cash.

My part of that was to come out here and work for my mother. It's so ridiculous how little it was, that I'm not even going to mention it because when my father found out how little it was I made for a day's work, he got very upset. 
C. Rowntree: She was having this little house built. I'm talking about 1932, the calendar year 1932. I think she'd completed it-almost all completed in that year. But it was during that year that I came out because it was in the fifth month of 1933 that I left my father and went into the CCC [Civilian Conservation Corps]. That doesn't have anything to do with my mother, so-period.

There's really not a great deal to say about her in that

Levenson: How did she react to Harriette when you brought her home as a potential daughter-in-law?

C. Rowntree: Well, let's see, that started sometime in 1932--I forgot what month of that year I met Harriette. Unfortunately, my mother got off on the wrong foot. She had had some impressions from other people about Harriette, about the family from which Harriette came or the family of which Harriette is a member.

She was a little negative about Harriette. She knew that Harriette was older than I was--I don't know whether she knew how much older. She took that as a negative point. And she'd heard some other things--I don't know how much of this you already know, but Harriette came from Atascadero and my mother had friends in Atascadero. It was a very small town where everyone knows everyone else. Separating the fact from the gossip is difficult for many people, so I'm afraid that my mother got some gossip in addition to fact, regarding Harriette.

To sum it up, she--my mother was kind of negative about Harriette becoming a permanent member of the family. After grandchildren came, that was overcome, I think. The first few years, it was sort of a little barrier.

Levenson: What was the gossip, or don't you want to say? It's up to you entirely.

C. Rowntree: No, I don't want to say, but the fact of the matter is, I can't really remember now what it was! But I don't think I'd want to repeat it anyway.

Levenson: [Laughs] Right.

What was your job in the CCC?

C. Rowntree: Again, I was fortunate--I say again I was fortunate because I've been fortunate so many times in my life as far as the work situation was concerned--If you have any information about the $\mathrm{CCC}$, you may remember that, while it was a civilian organization, 
C. Rowntree: it was administered by the anny. So, attached to every camp was an army captain and an army lieutenant at least; sometimes there was a sergeant too in the supply room.

In this case, the lieutenant was a fellow with whom I had attended high school. I'm not sure that we graduated in the same class, but that doesn't matter.

I enlisted at the Monterey Presidio, and after a few days there getting acclimated, they would ship us off in groups to various parts of the state. Because I was deeply involved with Harriette then in an engagement--that was our status, engagement --I did not accept the camp or the shipment to the camp--it's just over the hill here--what's known as Arroyo Seco, between here and King City--because I figured it was too close to home. There'd be too much tendency to be going AWOL [Absent Without Leavel and over the hill, and all that sort of thing.

I was given the information that there would be a shipment to Northern California, northwest part of California--Del Norte County--so I made known to my lieutenant friend that I'd like to go with that shipment of men, which I did.

Soon after we got there, this lieutenant came to me and said, "Got a job opening in the tool supply room." This was a pretty good job compared to going out in the brush and cutting trail or building bridges, or whatever. I said, "Great! I appreciate that." So they gave me that job for a few weeks. Then he came along again and he said, "They want a clerk down at the ranger station." This is the U.S. Forest Service. "Do you want that job?" I said, "Sure!" because I had an interest in forestry and it looked like it might be an opening wedge.

So he assigned me down there and I stayed there until the end of my hitch. That's how we got our entrance into the Forest Service. This was in about June or July of 1933, and my hitch was up the following May--May of 1934--and I couldn't re-enlist because I'd had two six months enlistments, and that was the limit. I wanted to stay in the Forest Service, so I said to the ranger with whom I'd been working all winter, "Is there a spot that you could put me during the fire season?" He said, "Yes. I could put you on such and such a fire outlook."

In the interim, I'd gotten married. Harriette probably brought this out--that on leave during Christmas, we got married. So I sald, "Great!" This is how this lieutenant helped me get started in the Forest Service and eventually the Fire Service. 
C. Rowntree: Do you want me to go on and on and on? We're supposed to be talking about my mother.

Levenson: That's all right. Perhaps if we could just summarize the rest of your career and then we can go back to your mother. So, after you did your lookout job?

C. Rowntree: We did a lookout job and then--of course, that employment ended with the end of fire season when rains came. So I changed the spelling of my name slightly and I went back into the same CCC camp as an Experienced Woodsman. There was a category for Experienced Woodsman--in other words, a local who lived there, a local person, because I'd been right there during the summer.

That was a very hard winter for Harriette. Here I was getting thirty dollars a month in the CCC and any meals that I wanted to eat there. We were living in a cabin that a kind person rented to us--quote rented to us--for twenty-five dollars a month. He certainly didn't get twenty-five dollars every month from us. Plus the fact that Harriette was pregnant and all of that. It was a tough winter for her.

Then the next summer, I went back into the Forest Service. Harriette was very pregnant. Fortunately, the ranger gave me a job down in clvilization as his assistant in the ranger station. That September, she had our first child [Rowan].

At the end of that fire season when I got laid off, we decided discretion was the better part of--we had a garage sale, packed up, Harriette's mother came up and got the baby and came back to Carmel on the train, and we drove down in our Model A roadster.

I started temporary work in the post office, and eventually permanent work. Then the war came along and I had my opportunity to get into the Fire Service via Fort Ord, and I've been in the Fire Service ever since.

If you want to talk about my mother, we could talk about the years of the winter of 1935 to the winter of 1943, I guess, when we lived here [Carmel]--we had communication, we had interchange, we brought the children out here. She came into our house and we had to, as you can imagine when you're dealing with divorced couples, you have to juggle them around so that you have your father there at one time and your mother there at another time, and so on and so forth.

Those were pretty good years as far as our relationship with my mother. 
Levenson: What was your perspective on what she was doing then? She was just starting her seed collecting business?

C. Rowntree: She was pretty well into it. She had her trips to the desert and trips to the mountains. It was just a coming and going sort of thing as far as she was concerned, because of her trips. They became fairly well standardized. I guess it was just after Christmas, she would go down to Twentynine Palms and stay with a friend of hers [Josephine Jackson] until March or April. She would come back for a little while. She would gear up for a trip into the mountains with her car or, as you've seen in some of the pictures, a burro. So it was that way: she was here and gone on her various trips throughout the year.

\section{Lester and the Grandchildren}

C. Rowntree: We didn't see a great deal of her. To repeat myself, the relationship was quite good. I'm sure Harriette's mentioned her concern about my mother taking the children off when my mother talked about having heart attacks. We don't know whether she really did or not. She was of the mind to think that she was having a heart attack now and then and, as Harriette said, she didn't want her children off in the hills or down on the rocks, or something like that if the guardian's going to have a heart attack.

That clouded the issue a little bit. Then my mother held it against Harriette, it made Harriette uneasy. It was all for naught because she certainly didn't have any heart attacks that we know of. She could have given the children a lot more exposure than she did, although she did guide them a great deal in their selection of a profession, through their association with her and her work.

Levenson: You're speaking of the boys now, Rowan and Lester?

C. Rowntree: Yes.

Levenson: Do you think she had as much influence on Patty?

C. Rowntree: No. No, I don't because, first of all, Patty wasn't born here. She didn't see Patty nearly as much as she saw the boys. When we did come out here to visit, the boys were old enough to know what she was talking about, were able to understand her-assimilate her information about plants and about nature a great 
C. Rowntree: deal better than Patty was. They were able to enter into the spirit of her work to a certain extent. She just didn't have the opportunity to influence Patty the way she did the boys. They just weren't together.

Lester's Contributions

Levenson: Looking back, speaking now from a perspective of forty years later, where do you feel that Lester's great contributions lay in the various fields in which she worked?

C. Rowntree: As far as contributions are concerned, I would sum it up by saying that the greatest impact was probably on people considerably younger than she was who either had an opportunity to hear her give a lecture, or had an opportunity to come here and talk with her on a one-to-one basis, or read articles that appeared in various public and organizational publications.

She had articles in the Los Angeles Times sometimes. More often, of course, in the trade publications of wild flowers, native plants, and so on and so forth. But I think those three areas were ones in which her greatest influence was made on the greatest number of people.

Levenson: Do you know what part she played in helping to found the California Native Plant Society?

C. Rowntree: No, I can't define it very well. I just know that she was instrumental in founding it. Obviously, that is why she is a perennial honorary president--

[Brief interruption while cat is let in.]

C. Rowntree: She was instrumental in that, and she was instrumental in working with an organization that tries to protect the desert, because she was quite familiar with the desert due to her many trips to Twentynine Palms, so forth, and Anzo Borrego Monument.

Levenson: Did you hear her lectures?

C. Rowntree: No, I have never heard her lecture. 
Dilemmas of Aging

Levenson: You and Harriette moved in here after the house was remodeled-how long ago is it now?

C. Rowntree: We moved in in September 1970.

Levenson: It's remarkable that your mother is as well as she is at ninetynine and a half. Do you have any comments that you want to make about the problems of aging, the problems of sons and mothers in this respect? To me, in many ways it's a beautiful thing to see her on the hill that she loves so much.

C. Rowntree: I could go on at great length about this. Some of it would be fact and some of it would be philosophy. I have to choose my words carefully. First of all, as has probably already been pointed out, Harriette volunteered to take care of my mother. I would never have asked her. I would never ask her to take care of my mother. She volunteered to do it, which is certainly a plus for her record. Of course, none of us knew what we were getting into.

But our children wanted to keep this property. My mother obviously wants to stay here as long as she can. I'm not saying that we made any great sacrifice to come here. It just wasn't in our game plan--this wasn't where we expected to retire, even though it's very, very nice.

I think I'm losing sight of the question. Give me the question again.

Levenson: I asked if you had any comments on the problems of aging in the relations of a son and mother?

C. Rowntree: Of course, in view of the present situation, my comments are very definitely that I hope that I--and I think Harriette feels the same way--I certainly hope that we do not impose ourselves upon our children. We're trying to plan our lives so that we are not going to be living with our children as we get older.

In some families it probably works out very well. It worked out fairly well in this family. Of course, it's getting tougher and tougher as time goes on, because we don't feel like leaving her the lengths of time we did before she had her fall, although she's taking care of herself pretty well. 
C. Rowntree: Anyway, in sumnary, if I was advising anyone else, I would say, based on what I've seen with other families and what I've experienced, I would advise against living together in the two generations, old people and the next generation or vice versa. I don't think they should live together. Or, they should certainly have an alternative to fall back on if they find it doesn't work.

Granted, things could be a heck of a lot worse. We could have my mother in a much smaller house, and it would be that much more difficult to take care of her. On the other hand, I just can't picture myself walking up to her ten years ago and saying, "You've got to get off the Hill. You've got to go into an old people's home" or something like that. I just can't picture myself saying that.

So what's the answer? I don't know. Everybody just kind of has to play it as it comes along. But again I say that no one should plan a long-term live-in situation or live-with situation of two different generations like we're into here.

Lester's Views on Death and Suicide

Levenson: How would you describe your mother's view of religion and her feelings about death, as far as you understand them now?

C. Rowntree: As I understand them now, it looks to me as though she's a little hesitant about accepting death compared to the way she used to talk. She used to talk about welcoming it and so forth, but I have a deep down feeling that she's not really looking forward to it. There's some hesitancy about accepting death.

I may be completely wrong. But in spite of what she says, I have that feeling. I can't substantiate it to any great degree, but I'm trying to pinpoint it to answer your question or to explain it but something has given me that thought. I'm apt to leave it there because I'm not going to be able to explain it--it's just a feeling that I have.

Levenson: When she was talking to me, she said something abut things left undone.

C. Rowntree: Well, yes, this is suicide. I've talked to her about that. I mean, not for her, but for others. She's very much against that because, just that statement that you got, she feels that 
C. Rowntree: a person must run their normal--whatever length of time the body decides to remain alive--we should not cut it short by our own hand. She feels very strongly about that.

Levenson: Do you think she describes herself as a Quaker now?

C. Rowntree: I think she would. I think she very definitely would. 
INTERVIEW NOTE

Harriette Rowntree: The Daughter-in-Law's View: "It's Been Worth It"

One long interview with Harriette was conducted on the morning of July 13 while Cedric drove the television crew in a four-wheel drive vehicle up the hill behind Lester's house. Lester slept peacefully in the apartment below. Meanwhile, Harriette and I sat at the dining room table talking while huming birds dived at Harriette's fuchsias and the blue jays protested vociferously. The next morning, Harriette wished to add some details, particularly on Lester's diet and mania for fresh air.

The changing ambivalences and strains in the relationship between mother and daughter-in-law are openly discussed. There was great generosity on both sides and major confrontations. Harriette says, "I think the thing that's remarkable, though, Rosemary, is the fact that this woman instead of becoming a neurotic, as many women today are--addicted to drugs or being completely neurotic and under the care of a doctor half the time--got out and did something about it and released this energy and her frustration through her garden, through the other things that she did. I think that this is admirable. I'm proud of her for it". (pp. 135-136).

According to Harriette, the fire that destroyed Lester's materials for her third book was set by an arsonist. (See Roof, pp. 75-78 for a different account.) Lester was impossible as a business partner (pp. 136-140) and yet had lifelong friendships with women and men in and out of the horticultural fraternity. Harriette notes how people continue to fall in love with Lester even in her hundredth year, and do not see the mean side of her ( $p .148$ ). "I think I have been [jealous]. I wasn't willing to face that till just recently. Yes, jealous because I couldn't understand this power she has over people. How can she have them slaves at her feet and yet I know what she says about them after they leave?" (p.148).

The transcripts were lightly edited, primarily for continuity. The package, inadvertently sent by library rate, took two weeks to travel from Berkeley to Carmel. It arrived the day that Harriette was driving her fourteen year old granddaughter, Erika, home to Los Gatos, and Erika read it aloud to her grandmother in the car. Minor editorial changes were made by Harriette primarily for stylistic reasons. The interview was then final typed, proofed and indexed. 
THE DAUGHTER-IN-LAW'S VIEW: "IT'S BEEN WORTH IT"

Harriette Rowntree

\section{Harriette's Background}

Levenson: Harriette, I am glad that you let us all come and do our television documentary about Lester Rowntree. I know you've known her since you met and married her son, Cedric. Would you tell me, first of all, a little bit about your own background? Where did your family come from?

Harriette Rowntree:

I was born in Sumit, New Jersey. Cedric and I, when we applied for our marriage license, discovered that we had lived, in our young years, within twenty-five miles of one another. He was born in Hackensack and I was born in Sumnit. Neither one of us knew this until we applied for our marriage license!

My father died when I was eight and my mother, a young widow with four children, wanted very much to go to New York and take a business course so that she could support her family. But at the time that my father died, we were living with my grandparents in Sumit, New Jersey. Both her father and her brother-in-law were in business in New York. They said, "No woman in our family is ever going to go to work."

Without their cooperation to take care of us children, Mother couldn't take her business course. So she took Daddy's life insurance which was only three thousand dollars and bought a ticket for California and brought the four of us out to a place called Atascadero; this was a planned development of Mr. E.G. Lewis', which should be in the historical archives of The Bancroft library because it was the first planned development in the state of California.

I was eight; my youngest sister was elghteen months old.

Levenson: What year was this? 
H. Rowntree: That was 1918. We grew up in Atascadero. One of the coincidences about my life and Cedric's and its inter-relationship is interesting. The innkeeper of the Atascadero Inn, which was the only inn or hotel in the community, was run by Mr. and Mrs. Septimus Martin, who came from England. It turned out that they were near relatives of the Rowntrees. In the course of time, when I met Cedric, it was through the Martins.

So I grew up in Atascadero and graduated, in 1928, from Atascadero High School. Then I went to the University of California for a semester, but the Depression caught up with everyone at that time and I had to come home. I got a job with the Pacific Telephone Company as chief operator. I was the youngest chief operator in the nation at the time, but then it wasn't a very big community. It was about five thousand people.

So I worked there for about four years and then, I began to be quite restless and asked for a transfer to a bigger

community. They sent me to Santa Cruz.

First Meetings with Cedric and Lester

H. Rowntree: I met Cedric on a visit to Carmel, where my family lived at that time. I came down to spend a weekend with my family. My brother was, at that time, just out of high school. He came into the patio one afternoon with this young man, Cedric Rowntree. My mother said to me after we were introduced and she got me off by herself, "You know, they're planning to go to Atascadero. Cedric's uncle is Septimus Martin. Did you know that?" I said, "No, isn't that strange?" She said, "Well, I don't want them to go. There's a girl down there that's after your brother. So please see if you can do something about diverting them to some other place." [Laughter]

We1l, I did. I succeeded in persuading them to go back to Santa Cruz with me to see Helen Wills play tennis. Cedric had a Model A Ford. I rode in the front seat with him, and my brother and another young man rode in the rumble seat. We had a marvelous weekend, ending up in San Francisco in a box seat to see Charlotte Greenwood play, because she was a friend of the other young man. On the long ride home, I was in the rumble seat with Cedric. [Laughter] That's where our frienciship began and it led to an engagement of over a year and finally marriage. 
H. Rowntree: All of this in the Depression. Cedric had come back from college and was trying to sell insurance and work with his father in a real estate office. He didn't have a dime for any fun of any kind. So 1 t was an interesting courtship. Fortunately, we both loved the out-of-doors and both loved to go hiking and exploring. Whenever he could get any gasoline for his car, we would take a little trip somewhere.

He finally decided that he was as much in love with me as he'd ever been in his life (apparently, he didn't have many girlfriends). And it was time that I met his mother.

Levenson: Would you tell me about the first meeting with Lester Rowntree and how you felt?

H. Rowntree: I was frightened.

Levenson: Why?

H. Rowntree: Because I had heard about her from other people and from some of Cedric's other relatives. I knew that she was becoming quite famous. She was doing a lot of lecturing and she had had several articles written about her. I'd never been presented to a potential mother-in-law before! I was twenty-one and very naive.

Anyway, I put on my best knitted suit. In the Depression, the best was the only one, and I did my level best to make myself look attractive. However, I was very thin. I'd had an infected tooth which had caused me to lose a great deal of weight, and almost have pernicious anemia. I only weighed ninety-eight pounds and I'm sure that $I$ wasn't a very impressive sight, even though I was young. When I look at my pictures now, I think, "Well, you really were quite pretty." [Laughter]

But I'm sure that Mrs. Rowntree, when she was introduced to this very skinny young woman, was not very pleased because good health meant a great deal to her, and I'm sure she was a little upset to think that her robust son would be involved with a skinny, ninety-eight pound weakling.

Anyway, we sat in front of the fire in the big house, which is down below us and still stands, and talked for a while. Then Mrs. Rowntree said, "Cedric, why don't you take Harriette out and show her the garden?" We jumped up with alacrity and escaped, and he gave me a tour of the garden, which I enjoyed very much because it was an interesting garden. I've always loved flowers and plants, and $I$ enjoyed it. 
H. Rowntree: We came back into the house to have tea. I sat down in front of the fire, and looked down at my legs. They were covered with burrs from my ankles clear up to my thighs. My beautiful knit suit was full of burrs. She had a plant, a ground cover, which she loved, which came from Greece, she said. It had a sweet, white flower, but in the fall, it had the nastiest burrs that you could ever imagine. It just digs into your stockings and clothes. [Laughter] So, we spent the next two hours pulling out burrs, and that was my first visit to my future mother-in-law.

Levenson: What was your impression of her?

H. Rowntree: Neither one of us could relax. We certainly didn't part friends. I didn't see her again for--oh, I don't think I saw her again for several morths. After we were a formally engaged couple, we came to help her in the garden. It was a difficult experience, but I think part of it was my own tension.

I asked Cedric last night, when we were thinking about this, "How many other young women did you take to meet your mother before I came along?" He said, "None. Never." [Chuckles] "You're the only one." I believe him. He was a shy boy and he did not have many girlfriends. He didn't have any serious love affairs like many young men do, like your own sons, perhaps.

I found it a difficult experience but we survived and Lester and I finally became good friends.

\section{Cedric's Upbringing}

Levenson: What about her relationship with Cedric?

H. Rowntree: We11, I have found this man with whom I've lived for forty-three years to be a wonderful person--kind and gentle, but I also find him to be gun-shy about women. He's had a terrifically bad exposure to women. Mrs. Rowntree had a friend and companion, Lila Clevenger, who lived with them off and on for many years. Apparently the two of them used to quarrel and bicker considerably.

Cedric gets upset even today with my sister and myself-if either one of us raises our voice in a disagreement. He says, "If there's anything I hate, it's bickering women. "He's gun-shy about women, and he's had an overdose. 
H. Rowntree: I had to take my mother to live with us, off and on, for ten years, and I've had to take in my own sister several times to recover from illnesses. He's taken it all with good grace, but this tension which manifests itself when there is more than one woman in a room, is a very sad thing to see. I think it goes back to those early days of his childhood with the constant disagreement between these two supposed friends. Because he has said so.

He says he remembers waking up on a camping trip and hearing them quarreling, which spoiled his whole next day.

I feel very strongly that Lester Rowntree was an excellent mother. I think she was over-conscientious. I think she tried too hard, and I think Cedric has paid a price for this overzealousness. But she was a faddist. There's no doubt about that. Her own best friend and her relatives have said, "You know that Lester is a faddist, don't you?" I said, "I couldn't figure it out before, but now that you've pointed it out, I understand more things."

She would go from one extreme to the other. This is particularly true about books she'd read on child raising. I asked Cedric the other night, "What kind of little boy were you, really? Did you ever go to public school or were you always sent away to private schools?" He said, "I was a mess. I was always sick; I was always complaining." I said, "I don't believe it for a minute," and he said, "It's true. And I was always being yanked out of school and sent to another one to see if I would do better."

I think part of this came from her over-zealousness, her desire for perfection. I think she swung the other way, too, because of her English background and having her brothers sent away to boarding school at the age of eight. I think she felt that that was the only way to make a man, you see. So that's why he was sent away to school at the age of eight, way out to California [from New Jersey]. He ran away three times. Does that answer your question?

Levenson: I think so.

H. Rowntree: I think that she was a good mother, but she was too intense a mother. I am surprised that he is as marvelous a person as he is, considering the fact that this was almost a neurotic child because of the way he was raised.

I know that his father and mother loved him dearly, and nothing was too good for him. That was the problem. It was too good for him. 
H. Rowntree: I remember Mr. [Bernard] Rowntree telling me about raising Cedric and how he would always go down to the driveway when the guests came and ask them not to make over Cedric. To me, this is unnatural. A child wants to be made over; wants attention; wants love. I sufpose this was the Quaker background of austerity and control of emotions in their time.

Influence of the Quaker Religion on the Rowntree Family

Levenson: How much influence do you think the Quaker religion had on the family--and on Lester, particularly?

H. Rowntree: I think the background of the way in which they were raised which, perhaps, was influenced by their religious beliefs at the time, may have influenced their behavior and everything that they did. But I didn't get the feeling that the religion, as I understand the Quaker religion, was dominant in either one of their lives.

I felt that the repressions of the Quaker religion of those days had its influence on them. The Quaker religion has changed enormously since 1879. They have an entirely different attitude now.

Mr. Rowntree, for instance, hated Christmas and felt that Christmas was a fraud. That we should do away with it. Yet he would come and spend all of Christmas Eve helping me wrap presents and trim the Christmas tree for his grandchildren, because my husband worked on Christmas Eve at the post office.

So you see, there's this divergence of feeling. Christmas, of course, was fine for his grandchildren because this was a cultural part of their inheritance. But in his heart, he felt it was a fraud.

The Quaker relationships of business and friends were very important to both of these people. They never lost touch with their Quaker relatives, with their Quaker friends, or business associates, but they seldom attended Meeting. Lester attended Meetings here, oh, twenty years ago when they started one in Pacific Grove, but I don't think that she went to Meetings more than ten or eleven rimes in the years that I've known her, and I've known her for forty-three years.

So you see, that part of the religion--the involvement with the Meeting, with the religious part--was not dominant, although 
H. Rowntree: I know that Lester believes that the Being, as she calls it, is in every rock, in every tree, in every leaf. The Quakers believe this also. God, or the creator, is in everything. I know this. But I know how she hated not being able to sing. She has made some very acerbic remarks about Quaker Meetings. The only Meeting I ever went to with Cedric in Berkeley was a difficult experience for me.

The Berkeley Meeting House has a nice fireplace and there was a lovely fire burning. We walked in and sat down in complete silence. Not a sound was heard in the whole room, of course, and $I$ was very edgy and fidgety at first. Then I began to relax and have a feeling full of peace and quiet. Just as I was beginning to enjoy the whole thing, some old codger got up and expounded on [laughs] his theories of religion and spoiled the whole thing for me. I never went again because I just felt that I didn't understand. I enjoyed my Congregational church, I enjoyed the service and the singing.

Cedric went to church there with me and enjoyed it. He's a birthright Quaker, but he's not a practicing Quaker.

The Rowntrees and Music

H. Rowntree: Lester apparently had a lovely voice when she was younger, and she loved to sing. There was even some talk about her taking voice training but she thought that was stuffy, so she never would do anything about that.

She and her brothers used to love singing, and when I first came into the family, Uncle Frank Lester was living in Monterey. They had a piano and they used to have Miss Clevenger, Mrs. Rowntree, Cedric and myself, for Thanksgiving dinner. We would always end up around the piano, singing. Uncle Frank loved to sing. Lester loved to sing. Cedric can't carry a tune worth a darn, but he used to sing too. We had some jolly good times. She had a lot of that with their family apparently. They played banjos and guitars, and did a lot of singing.

She has said to me many times she couldn't live without music. She spent a lot of money getting good stereo equipment here and a good collection of records. After dinner, almost every night, we put on records. I go downstairs now and put records on for her and she lies there and listens contentedly by the hour. Music has played a very important part in her life. 
H. Rowntree: One of her favorite stories (which you may already have) is that she loves Mahler. Yet we have a good many Mahler records, and people are always giving her Mahler records--but there's only one Mahler record that she really likes. This is the one where the trumpets take a solo part.

She tells about when she was collecting in Mexico. She was in her sleeping bag one night, somewhere in the woods, and heard these trumpets coming through the woods. Young musicians were returning from a concert where they'd been playing Mahler. They were playing the theme from the--I forget the name of it now--but there's a lovely theme in one of Mahler's symphonies.

Levenson: We'11 pick the title up later.*

H. Rowntree: She remembers that and thinks that she loves Mahler for that reason. Mahler is quite heavy and very sad. She leaves the room. So she just picked that up, you see, and thinks she loves all of Mahler, but I know she doesn't.

Levenson: Does she have any particular favorites?

H. Rowntree: No, but she's much fonder of chamber music than anything else. I love concertos, for instance. She would rather have a string quartet. She loves stringed instruments.

She really enjoys all music. Friends, over the years, have given her season tickets to the symphony here, and to the Bach Festival. With Mrs. [Josephine] Jackson, she used to go down to Pasadena during the symphony season.

\section{A Liberated Woman?}

Levenson: [Chuckles] We were talking, the television crew and I, last night about Lester's attitude to women. And you just mentioned that she doesn't like women. I've seen some interviews with her that have been published where she said women's lib. was not for her. What do you think she meant, feels?

\footnotetext{
*Probably the last movement of Mahler's Second Symphony.
} 
H. Rowntree: I honestly--this has always perplexed me. She has two intimate women friends who are devoted to her. She spent three months of every year with Josephine Jackson on the desert [Twentynine Palms]. Marvelous companionship and relationship, although she bossed Mrs. Jackson, who was a very wealthy, spoiled woman, and takes great pride in telling how she got Josephine to learn to cook her own breakfast.

This was a relationship that endured for fifteen years. Josephine died and left her some money. She tried Josephine beyond endurance by her sleeping pills and the fact that she wouldn't get up until one or two o'clock in the afternoon. She also insisted on fresh air--this is one of her idiosyncrasies that exists even today.

We took her into the hospital [May 1978] and the first thing that she said was, "Got to have fresh air! Open the window!" The poor lady who was in the room next to the window had to endure having this window open on her.

This is the idiosyncrasy that is dominant in her life, fresh air. Just got to have the windows wide open.

Poor Mrs. Jackson would sit there in the living room of this high desert house, where the air in November is cold, swathed in rugs, reading to Mrs. Rowntree, who was lying supine on the couch, swathed in rugs. And Josephine sitting in the chair with the breezes blowing over her legs!

Lester tells about how one day Josephine said, "Lester, I know you have to have fresh air, but do we have to be so cold?"

Levenson: [Laughs] Poor soul!

H. Rowntree: That was true here, in this little house. She had every door and window wide open. She would be lying on the couch with an Indian rug over her, and anyone who was talking to her was sitting in a chair with a draft, the cold wind blowing over your legs until you wanted to die. And yet, people would come and sit by the hour.

Levenson: Women's 1ib. It's a difficult subject to cope with as far as I'm concemed because it means so many different things to different people.

H. Rowntree: You see, she has no understanding of what today's women's lib. means. She was brought up in such a male chauvinistic regime: her father, her husband, her brother--and when she did finally get the divorce, she was in her late fifties. No, fifty? 
Levenson: Fifty-three.

H. Rowntree: Fifty-three. That's pretty late in life to be suddenly liberated, when you haven't been used to freedom. I think she'd find it very hard--although I know she has counseled innumerable people who have come here who have had unhappy marriages, "Chuck it. If you're not happy, chuck it."

Yet, when her own grandson and [grand] daughter-in-law decided to get a divorce, she was heartbroken. She has finally accepted $i t$, and realizes now that it was for the best, and they're both happier people, because they faced it and faced it early. The great-granddaughter is not suffering one bit. I think, at her age, this is terribly hard to accept.

I'm sure that if she were, today, a woman of your age [fifty-one], she would be all for women's lib. and be understanding of the movement.

Victorian Attitudes to Sex

Levenson: You mentioned her unhappy marriage. She said something that touched me very much--on videotape--that she had been "ungenerous, with her body."

H. Rowntree: Really?

Levenson: Yes.

H. Rowntree: What did she mean?

Levenson: I suspect she means that she was not a good sexual partner. That's the way I took it.

H. Rowntree: I would think that that would need a lot of understanding. I think that you have to go back to the way they were both brought up. Sex was hidden, forbidden. The story of hiding the baby's birth and pretending it came from an owl's pellet. I told you that story. Do you want that on the tape?

Levenson: Yes, please. 
H. Rowntree: I got this from Skee Hamann's writing*. When Lester was born, she was the sixth child of eight. Her brothers were, I would say, in their tenth, eleventh, twelfth years--old enough to know where babies came from, surely, but they were all herded off to Meeting or something--everybody was gotten out of the house. Of course, all the births took place at home in those days, even mine.

When they came home, here was the new baby. These boys were very curious about where this baby came from. They lay in wait for the doctor, who was upstairs with their mother. When he came down the stairs, they surrounded him, and demanded to know where this baby came from. The doctor said, "We11, I was walking in the Brae Woods this morning, and an owl flew over my head and dropped a pellet. And I caught it. Out of it, came this baby." She says she was called "Pellet" for many years after. [Laughter]

That's how little they knew abut sex in those days. I knew Mr. Rowntree wel1--I know what a frigid person he was when I first met him. I know how reserved she was when I first met her. It wasn't possible to go up to Mr. Rowntree and put your arms around him and kiss him when I first met him. Only the last years of his life were we able to do this together.

How could they have any kind of a decent sex life that way? I expect it was pure rape. I really do. Because she told me that even after they were not speaking to one another except in front of Cedric, he still came to her bed at night. I think he probably felt he was entitled to it. Why should he pay to go to a whorehouse? That is the kind of sex life that these people endured. If she was not generous with her body, she was probably protecting herself.

I really felt terribly sorry for both of them. But that's the way it was. They're not alone. Look at the people of their generation--even yours and mine. [Laughter]

I think the thing that's remarkable, though, Rosemary, is the fact that this woman instead of becoming a neurotic, as many women today are--addicted to drugs or being completely neurotic and under the care of a doctor half the time--got out

*"Runaway," by Skee Hamann, 100 pp manuscript to be deposited in the archive of the California Academy of Sciences. 
GBRTRUDE BLCWN IBSTBR ROTNTRRE

BOx 986

Carmel-by-the-8ea

Oalifornia

Representing Tab-Bdged 8ystem. Inc.

I am going to make a garden. You w111 appreclate that 1 t $\mathbf{w 1}$. be some job when you learn there are nearly three aores of land surrounding our howe.

As this 18 to be my garden. I am going to earn the money to buy what I need. The work I vill do myself.

Ur. Rowntree suggested that I write to you about this new carbon paper which he bas tried and pronounced to be a great time saver. It is manufactured by a friend of ours who has had jears of experlence and knows how to make the best.

I will send you enough for a trial if you will ask jour stenographer to use 1t. It may take a fow minute to become accustomed to the new way of handing 1 t.

Please tell wo whether your typewriters are the ordinary or nolseless type.

Yours truls,

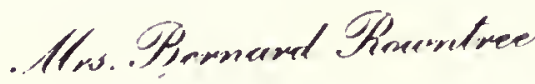


GERTRULDE ELLEN LESTIR ROHNTREE

Box 986

Carmel-by-tine-Sea

California

Representing Tab-Edged System, Inc.

4 1b. carbon paper is the best. Always use for 8 or more copies. 5 lb.carbon paper is heavier. Use this for less than 8 coples. 7 Ib.carbon paper is cheaper. Can be used for 1 to 4 copies.

For Ordinary Typewriters.

No. 481 ; 4 Ib. Imported Crompton.

No.582 - 5 1b. Imported Crompton.

No.785i - 7 Ib. Tard Tissue - medium finish.

No. $715 \pi$ - 7 Ib. Durable - hard finish.

No.784 - 7 Ib. Blue Back.

No. 481 and No.582.

Price per box.

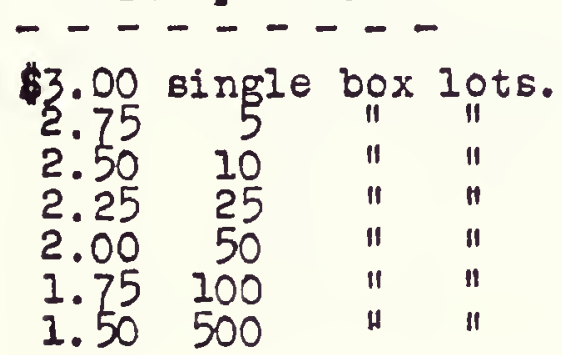

No.785\% and No.715\%. Price per box.

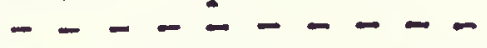

$\$ 2.50$ single box lots.

2.0010 " 1

$1.7525 \quad$ "

1.50

1.30

1.10500

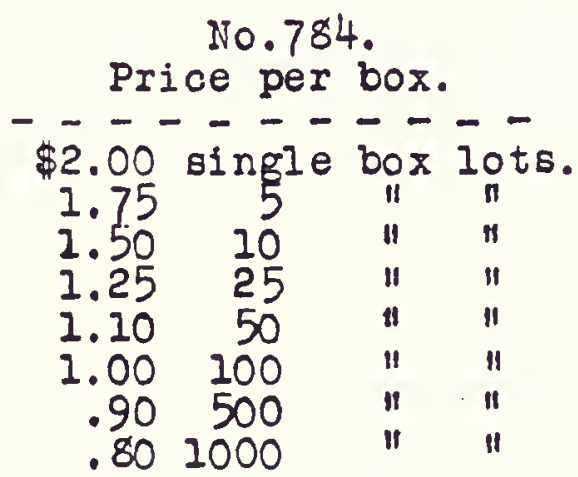

100 Sheets to a box. Either $8 \frac{1}{2} \times 11$ or $8 \frac{1}{2} \times 13$. State size required. Delivery by mall - postage prepaid. 
H. Rowntree: and did something about it and released this energy and her frustration through her garden, through the other things that she did. I think that this is admirable. I'm proud of her for it.

Levenson: That's a lovely conclusion.

H. Rowntree: What else is there? I do understand the hardships. I think the marriage was happy at first, but neither of them knew what to expect from marriage. They were just doing their duty. The only thing that a woman could do in those days, really, was to get married. It was just accepted. You got married. The man had somebody to keep house for him and take care of him. He fed this woman and clothed her in return. That was it.

It isn't as it was when you were married even, as young as you are. You're so much younger than $I$. But in my day, careers were second; marriage was first. In Lester's day, it was only marriage. What a difference! I don't think that Lester, with her great age, can accept this change. Or can even understand it. But she would approve the differences, I think.

Iila Clevenger: Friend, Companion, and Partner in the Native Plant Seed Business

Levenson: Do you think we should stop for a moment?

[machine off]

Levenson: The question that I was about to ask when the garbage truck came by and the dogs went crazy, was about Lester's relationship with her partner, Lila Clevenger, and the terrible problems that arose at times in that relationship.

H. Rowntree: It's a very sad story.

Levenson: First who was Lila?

H. Rowntree: Lila Clevenger was a schoolmate at Westtown school. [A Quaker school in Pennsylvania.] I don't think that Lila was of Quaker extraction. I've never heard she was. She was a very nice person-a very sweet person, and a person who was one of these unfortunate people who was a follower rather than a leader. She had very bad eyesight and I think, even as a child, had to wear double-lens glasses, which made her strange and peculiar 
H. Rowntree: to other children. I think from what 1ittle I've known or learned from both Lester and Lila Clevenger, that Mrs. Rowntree felt sorry for Lila and befriended her.

Lila became her devoted slave and would do anything for her. Their friendship continued long after West town school. When Cedric, my husband, was born--Mrs. Rowntree is a very small person and she was badly torn. It was a very difficult birth. She was bedridden for many, many weeks afterwards. Lila came and kept house and took care of Cedric for a long time.

Then when the war came in 1917, Lila went to France with the Women's Corps and was gone, of course, all during the war-then came back into their life at the time that Mrs. Rowntree had a hysterectomy. She supposedly had cancer, which we very much doubt at this point in time, but anyway, she had a hysterectomy, and Lila again came and kept house.

Apparently, Miss Clevenger was in and out of the Rowntree household all the rest of their lives. When they came to California, she came out also. In fact, Mrs. Rowntree and Miss Clevenger had a trip to England together before Cedric was born. There are pictures of them in Scarborough, and relatives there remember that visit. So it was a close relationship for many, many years.

When the Rowntrees built the big house down below us here, Miss Clevenger bought the land above and built a little house, which is down at the end of this road. Cedric, I think, will tell you that when Mrs. Rowntree was off on trips, Miss Clevenger kept house for him and for his father, and apparently lived in the big house--and did this many, many times.

After the Rowntrees were divorced [1932], Mrs. Rowntree and Miss Clevenger went into the California native plant seed business, and built a nursery up here on the side of the hill. Miss Clevenger was the secretary--she wrote the letters and did the mailings, and watered the plants when Mrs. Rowntree was gone. She followed instructions to the letter and kept everything alive. She was not the gardener, but she could water and could sort seeds, and so forth. She kept the business going.

Mrs. Rowntree did the collecting and then brought the plants and seeds back, and propagated them. They had a flourishing business and mailed seeds all over the world. I think you have some statistics on this from other sources. It was an excellent business, and without Miss Clevenger of course, could never have been possible. 
H. Rowntree: This continued for a good many years. Miss Clevenger was always at home. She never had a vacation. She never had a trip; never went anywhere, because the seeds and the plants couldn't be left.

The Depression came and Miss Clevenger's income, which apparently was from her family, which had been adequate, I guess, was reduced considerably and she was almost in poverty.

We didn't know any of this at all. Mrs. Rowntree also found, at that time, that she could not continue this business alone. She had met a Mr. E.K. Balls, an Englishman who was a botanist-and they decided to go into business together when he retired. He was with the English Quakers. His last assignment was in China. Then he was to retire.

Before he and Mrs. Balls went to China, they came and stayed with us in Berkeley, and came down here and went over everything, and decided they would go into partnership with Mrs. Rowntree. But before he would consider putting any money on the line for the partnership, he wanted an audit of the books. He wanted to see exactly what the financial status of the seed company was.

Apparently, Mrs. Rowntree had a friend who was an accountant and she came down and went over the books. At that time, they found that Miss Clevenger had not been putting the money back into the business that she should have--in other words, the books were a mess. Mrs. Rowntree felt that Miss Clevenger was dishonest. Hard words were exchanged. It ended up in court.

The property on which the nursery had been built was owned jointly by Miss Clevenger and Mrs. Rowntree. Since there was a break in the relationship, the property had to be divided. It had to go into court because they were not speaking to one another.

Cedric and I knew nothing of this until it was all over. We were instructed that Lila was dishonest and that we were not to have anything to do with her. Well, we couldn't accept this. Cedric loved Lila. She had cared for him all his life, and I loved Lila. She and I were good friends. I gave her her first cat. Finally, she had ten cats altogether! 


\section{Broken Partnerships: Lester Surrounded by Enemies}

H. Rowntree: We just couldn't accept this at a11, but the damage had been done and there was nothing that we could do to restore the relationship. So this was a very unfortunate situation. It ended up in a good many tragedies. Lila had a neighbor who was very fond of her, felt sorry for her, because after this business took place, Miss Clevenger went to work in the laundry and worked long, hard hours, because she had no other way of earning a living.

This friend, who was a widow, had a Filipino houseboy and she used to have Lila come over there for dinner every night, which was a godsend, because otherwise Lila probably wouldn't have eaten. Apparently, Miss Clevenger transmitted some of her sorrow and hatred and despair about this whole business to Mrs. Daugherty. The houseboy overheard--he also was very fond of Lila--and attempted to burn Mrs. Rowntree out three different times. He succeeded in burning the whole seed storeroom and warehouse completely to the ground. All of Lester's photographs and pictures and manuscripts of her third book went up in flames.

Levenson: Was Mrs. Rowntree in?

H. Rowntree: No, she was away at the time, and friends were in the house. The other fires were caught early and so no great damage was done. He burned down the woodshed one time.

The Filipino boy had a record of arson, when they finally tracked it down to arson. They never could prove anything against him, but he ended up crashing his car into a telephone pole.

Levenson: A terrible story.

H. Rowntree: A terrible story--truth is stranger than fiction.

Miss Clevenger got cancer later on and died. Mr. and Mrs. Balls, who found that they could not work with Mrs. Rowntree after a11, and dissolved their business relationship, were living here at the time that Miss Clevenger was hospitalized. They visited her and befriended her, and took care of the cats. She ended up by willing all of her property to the Balls. Actually, the property legally was registered, even after the lawsuit--in the names of both women with the right of survivor- 
H. Rowntree: ship. But the Balls persuaded Mrs. Rowntree to sign a quit claim, so they got the property on both sides of us. Therefore, the Balls were no longer people we were to speak to. her.

So here she was, surrounded by enemies on either side of

Lester and her Grandsons: Sharing her Knowledge and Love of Nature

Levenson: We were talking, a moment or two ago, about rather sad things. What are some of your happy stories about Lester?

H. Rowntree: When you say happy stories, I really don't know exactly what-so much of my involvement with Lester has been one of hardship. And yet, she had so much to give to the children that I used to make terrific sacrifices in order that the children could be exposed to her and to her knowledge and to her love of nature.

When I think about this, I realize that some of those times were happy times too. For example, she supposedly had a heart attack. We are pretty sure now that it was just nerves and tension, but it was called a heart attack.

She was very much in love with my two darling sons who were eight [Lester] and ten [Rowan], and just beginning to be aware of the world around them. She was so wild to be sure that they got proper exposure that would enrich their lives, particularly their exposures to nature, that she would make a great effort. She would come to Berkeley, complete with station wagon, sleeping bag, buckets and pails, and all kinds of things which she used for collecting trips. She had taken all the seats out of the Packard station wagon except the driver's seat, so anybody who rode with her had to sit on the floor on the sleeping bags, amid the buckets and pails and things.

I was very reluctant, as was Cedric, to allow these two boys to go off on day long trips with a woman who'd had a heart attack. Our sons were too precious to us, and I felt those years were too critical--that they didn't need to have a traumatic experience such as their grandmother having a heart attack somewhere out in the wilds or on the Bay Bridge. 
H. Rowntree: So I said that certainly she could take the boys, but I must go along. Well, now that I'm a grandmother, I know how that must have irritated her. I love to have my grandchildren to myself, and $I$ am sure that she disliked having this mother trail along. But I always stayed in the car and read. I never tried to interfere or follow along in any way.

It was hot and uncomfortable, and sitting on the floor of the car wasn't very much fun. But I do feel that she gave the boys so much, it was worth the sacrifice.

I remember particularly a trip on Mt. Diablo on a hot, hot day. We stopped suddenly. She was a dreadful driver for one thing--

Levenson: Really? [Laughter]

H. Rowntree: Yes.

We stopped on a curve of the mountain road all of a sudden. She would see something--a plant or shrub--and she would just apply the brakes, no matter what was behind. We stopped abruptly and she said, "Come, come with me." She got the boys out of the car. My curiosity was aroused, of course, so I followed this time. We went and stood over the brink of this canyon, there was a culvert under the road. She said, "Now, this is the perfect place for a rattlesnake." And there was a rattlesnake curled up in the shade of that culvert, and he had just eaten a big meal of gophers or something--you could see his distended belly--sound asleep. That was my first rattlesnake, also. The boys had never seen a rattlesnake either.

This woman with her intuitive sensitivity about nature knew that was the place for rattlesnakes on a hot day. There it was.

Levenson: Marvelous.

H. Rowntree: This is the kind of thing that she taught these children. She loved to bring them books. She spent a lot of money on books for the children, and they were appreciated and loved.

Writes Children's Books

H. Rowntree: I think one of the unfortunate experiences in her life was her

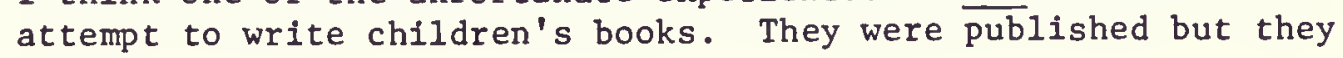


H. Rowntree: ship. But the Balls persuaded Mrs. Rowntree to sign a quit claim, so they got the property on both sides of us. Therefore, the Balls were no longer people we were to speak to. her.

So here she was, surrounded by enemies on either side of

Lester and her Grandsons: Sharing her Knowledge and Love of Nature

Levenson: We were talking, a moment or two ago, about rather sad things. What are some of your happy stories about Lester?

H. Rowntree: When you say happy stories, I really don't know exactly what-so much of my involvement with Lester has been one of hardship. And yet, she had so much to give to the children that I used to make terrific sacrifices in order that the children could be exposed to her and to her knowledge and to her love of nature.

When I think about this, I realize that some of those times were happy times too. For example, she supposedly had a heart attack. We are pretty sure now that it was just nerves and tension, but it was called a heart attack.

She was very much in love with my two darling sons who were eight [Lester] and ten [Rowan], and just beginning to be aware of the world around them. She was so wild to be sure that they got proper exposure that would enrich their lives, particularly their exposures to nature, that she would make a great effort. She would come to Berkeley, complete with station wagon, sleeping bag, buckets and pails, and all kinds of things which she used for collecting trips. She had taken al1 the seats out of the Packard station wagon except the driver's seat, so anybody who rode with her had to sit on the floor on the sleeping bags, amid the buckets and pails and things.

I was very reluctant, as was Cedric, to allow these two boys to go off on day long trips with a woman who'd had a heart attack. Our sons were too precious to us, and I felt those years were too critical--that they didn't need to have a traumatic experience such as their grandmother having a heart attack somewhere out in the wilds or on the Bay Bridge. 
H. Rowntree: So I said that certainly she could take the boys, but I must go along. Well, now that I'm a grandmother, I know how that must have irritated her. I love to have my grandchildren to myself, and $I$ am sure that she disliked having this mother trail along. But I always stayed in the car and read. I never tried to interfere or follow along in any way.

It was hot and uncomfortable, and sitting on the floor of the car wasn't very much fun. But I do feel that she gave the boys so much, it was worth the sacrifice.

I remember particularly a trip on Mt. Diablo on a hot, hot day. We stopped suddenly. She was a dreadful driver for one thing--

Levenson: Really? [Laughter]

H. Rowntree: Yes.

We stopped on a curve of the mountain road all of a sudden. She would see something--a plant or shrub--and she would just apply the brakes, no matter what was behind. We stopped abruptly and she said, "Come, come with me." She got the boys out of the car. My curiosity was aroused, of course, so I followed this time. We went and stood over the brink of this canyon, there was a culvert under the road. She said, "Now, this is the perfect place for a rattlesnake." And there was a rattlesnake curled up in the shade of that culvert, and he had just eaten a big meal of gophers or something--you could see his distended belly--sound asleep. That was my first rattlesnake, also. The boys had never seen a rattlesnake either.

This woman with her intuitive sensitivity about nature knew that was the place for rattlesnakes on a hot day. There it was.

Levenson: Marvelous.

H. Rowntree: This is the kind of thing that she taught these children. She loved to bring them books. She spent a lot of money on books for the children, and they were appreciated and loved.

Writes Children's Books

H. Rowntree: I think one of the unfortunate experiences in her life was her attempt to write children's books. They were published but they 
H. Rowntree: were not successful. Even her own grandchildren didn't enjoy reading them. One of the great-grandchildren wrote a letter not too long ago from her school in Oregon, in which she said to us, "We are reading Ronnie and Don in our classroom. It's a good book, Nanniesther-we like it."

Levenson: That's really great.

H. Rowntree: We thought that was nice. Because Lester is embarrassed about the books. I feel what she did wrong there was she tried too hard to come down to the child's level and make it an exciting adventure story. The parts of those children's books that are precious are the descriptions of nature--the animals and scenes that are described throughout the books. If she had concentrated on that, she'd have had a best seller, because she can describe nature and animals and birds in beautiful language, and language that a child understands.

But she needed money, and somebody said, "Why don't you write children's books?" So she got up on her hind legs, as she says, and wrote them.

Levenson: That was a great scene yesterday, wasn't it? [The television taping with Lester]

H. Rowntree: Yes.

Lester's Finances

Levenson: This business of money has interested me somewhat. How poor was she, really?

H. Rowntree: She had a great ability to attract money. She has a terrific personality and people either like her very, very much and want to do things for her, or they dislike her and will not have anything to do with her. There's no halfway with Lester.

She had many wealthy friends. She attracted money when she needed it, and was always able to get it. We don't talk about this kind of thing, but we know now how many gifts were given-and they were never loans--we don't know how much she made herself. Not very much, because Cedric did her income tax, and has done it for the last twenty years, and there was never any tax paid. So what she made for herself was minimal. 
H. Rowntree: Her Packard station wagon was a gift, for instance, from a wealthy friend. Many things like this. But I feel it would hurt her very much to hear this said. But [Bernard] Rowntree used to say that this was something that very much embarrassed him, this show of poverty when they really were not poor. This was one of the things that caused a great deal of marital trouble, I'm sure.

I don't think that she realized what she was doing, but it's again, "Get up on your hind legs and do it." She had a goal and anything that would help to achieve that goal was cricket, I guess.

There never has been very much money. She certainly was a very fine manager of what little money she had. I think she got a very good settlement from her husband at the time of the divorce. She got the big house, which certainly must have been sold for quite a nice sum of money. And several investments. She hoarded them wisely and took care of them well. She was given an annuity by her friend, Mrs. Jackson, which is still paying a hundred dollars a month.

She wrote for the Los Angeles Times for many years--had a weekly article, I believe. She wrote for Sunset and West Ways. She certainly received fees for her lectures. The books must have paid a little, but according to what records we have, not very much money was made from the books. I expect that the advance that they gave just made it possible for her to stay home and write rather than to go out and lecture and travel. I suspect it was used up very quickly.

She had a number of wealthy friends who were very interested in her work and what she was doing. I'm sure that from time to time, they helped her out. We know very little about her finances.

\section{Lester's Goals}

Levenson: You've talked about her goals. Now I have a list here of some of the labels that have been applied to Lester, and I realize that she is so individual and multi-faceted that it's hard to label her: conservationist, seed collector, expert on California native plants, gardener, garden designer, writer, lecturer, photographer. Now, you say a goal. Would you talk, at your own discretion, about her goals, how successful she was, and what her contributions were? 
H. Rowntree: I feel that she was outstandingly successful. I think that she has an amazing mind. A person with a high school education who could master the botanical language and technicalities that she has mastered--who can learn photography and do the beautiful job that she did with her pictures, and who could, without any background or education, become one of the most prominent women in the United States--she's one of two who've been accepted by professional horticultural organizations, who have not had degrees. I believe Alice Eastwood is the other one. I was told by Margaret Campbell that Lester and Alice were the only two who had been accepted and honored by professional organizations in the horticultural world. She is an amazing woman. She is a genius and she has the drive of $a$ genius. Take any genius that you know--Mozart, any musician, any writer, who has become acclaimed by the world or by the nation in which they live--they've all had a goal and nothing has deterred them from it.

Two Generations in One House: Strains of Living with an Aging Genius

Levenson: I know that you and Cedric gave up a lot to come here [Carmel Highlands] and live with Lester. You gave up your own home, you enlarged this house, and it's been very strenuous and trying for you. But you said, "Lester's a genius, and geniuses take it out of other people."

H. Rowntree: Yes. I gave up my own home to come here after about four years of trying to take care of her from Berkeley and San Jose, and having to come down for endless small things, and having her fall and crack her ribs and have to take her home, and trying to keep people living with her. Finally, after our daughter was married and left home, I said to Cedric, "I don't think that it's worth what we're going through to keep your mother alone. Why don't we sell our house and put the money into enlarging the Highlands property, since everyone in the family loves it?"

There's a lot of tradition here. Cedric and I spent our wedding night here. Our three children also spent their honeymoons here. A grandchild was born in this house.

People from the botanical and naturalist world have been guests here. It's a beautiful spot. We all love it. If we didn't do something like this, the house would have been sold to take care of Lester. And her life wish was that this 
H. Rowntree: property go to the children. There wasn't any other way to keep it.

We finally got her to agree to letting us build on to the house. That, in itself, was an experience that no one would believe. Two sons and two daughters-in-law and your own self and your husband your mother-in-law in on the architect's drawings [laughter] trying to please everyone in the family before you do anything.

I could write a book about that experience alone! But we finally accomplished it. The first year was a very difficult year. There's no question about it. If we hadn't had an apartment of our own downstairs, where Cedric and I could go to be alone, and where Lester could be alone upstairs in her familiar surroundings, I doubt very much if we could have continued.

Here was a woman who had lived alone for thirty-two years and had done just as she pleased in her little house--could have gone naked if she wanted to, slept all day if she wanted to, write all night if she wanted to--and for her to have other people come into her home was difficult for her. It was difficult for me to have to adhere to my mother-in-law's ideas rather than my own, and try to adjust to a very dominant woman whose tastes were very simple. For instance, there wasn't a comfortable chair in her house.

Cedric and I both like comfort. There were no curtains. She kept a very austere house, for the reason that she didn't have time to deal with housekeeping. Even in her married life, when I first went in to their big house down the lower part of the property here, there wasn't a comfortable chair in the whole house. It was simple and austere, believe me. The most austere kind of living. For someone who loved comfort and beauty of domestic surroundings, it was a very hard adjustment. However, we made it.

There was something I wanted to bring up [musingly]--go on--there was something that I wanted to tell you, but--

Levenson: I think you wanted to talk a little bit about your feelings and the difficulties as a woman, as a daughter-in-law, living with a genius, and how somebody helped you when you were almost desperate--

H. Rowntree: Oh, yes--my first two years--after about six months here, after I got the house in order and everything unpacked, and got settled down, (Cedric was doing a lot of traveling) I was left 
H. Rowntree: alone here. She didn't need any care. She slept most of the day, and all she needed was dinner.

So I got involved--very heavily involved--in helping a group start a volunteer bureau here. So, for two years, I gave them my time. It was a life-saving experience for me because it helped me through this adjustment period of giving up my own home and being subservient to a mother-in-law, and having to learn a whole new way of life. It carried me over those first two years.

But then, Mr. Rowntree [Cedric] began to be terribly unhappy about my not being able to travel with him, because he was assigned for two and three weeks at a time on some of his teaching duties, living in motels, and eating meals in restaurants. It began to show in his health and his nervous system.

We were very fortunate in finding someone who came here to live, and was here for two and a half years. I can't say that the first seven years were all that bad because I had the volunteer bureau and then I was able to go away with my husband. It's only been since Mr. Rowntree has retired that it has been a real problem because income is reduced, you see, and we can't afford to have someone come and live in. Therefore, we can't travel and we can't do the things we've always dreamed of doing.

We're beginning to wish that this little woman could do what she's wanted to do for all these many years, and go, so that we could be free again. And she wants it as much as we do. But I don't think she realizes what she's doing to us. I think she's gone beyond that. She doesn't realize how she has clipped our wings. I think that's all gone out of her thinking now. She's just trying to survive or live each day as it comes and try to endure.

But I did have some dreadful times adjusting to not being able to express my own home-making instincts in those first years. Also I found it awfully hard, as did Cedric, to understand this aging person who one day was a child, and the next was, again, a genius. It was hard to understand why people still kept coming and sitting admiringly at her feet, when we knew it was just a record that she was giving out. She was just repeating over and over again the things that we have heard all of these long years.

It's very hard for a son and daughter to see the change in this person who has been Mother and to whom we have deferred, and then find that you have a child on your hands some days. 
H. Rowntree: And other days, you have Mom back again, and Mom wants this and that done. This is true for everyone who's living with aging people. It's something that, I guess, is part of the geriatric studies that they're doing now, trying to teach us all to understand what's happening to our minds and our bodies.

It would seem that the recordings--the old recordings--are not destroyed. Even your childhood memories and recordings are not. She can talk now--today--about her childhood. You know that. Yet she can't remember that you were here yesterday. So the new recordings are not made. It's as if yesterday didn't exist. So each day, you start fresh with this person. But, as I say, I could not seem to adjust myself and my thinking, and I couldn't seem to understand this woman and her idiosyncrasies, and I kept suffering acutely over this.

One day a friend was here (who was very close to me) for about a week and saw the things that went on here, and saw how I was suffering and trying to understand, and said, "You know, Harriette, what you forget is that you're living with a genius. No genius has ever been easy on their family."

It made me feel better. It made me understand a little bit and, therefore, I became more relaxed about the whole thing, and I didn't take personally some of the things she would say. I was experimenting, for instance, with trying to make the guest room a little bit more cheerful with some orange and yellow colors.

She walked in and said, "I wish Heidi were doing the decorating around here." Heidi is my son, Lester's, wife. We11, of course my feelings were hurt--

\section{Levenson: $\quad$ of course.}

H. Rowntree: --and I cried.

One day she said--she was told that the grandchildren were coming to visit and she said, "Well, I'm certainly glad they're not the Nash children!" The Nash children are my daughter's children.

She has never liked women and she has never been as fond of Patty as she has of the boys.

Well, you couldn't help but have your feelings hurt. Those children were just as precious to us as our sons' children. Things of this nature, which you find very hard to understand in a person who people fall in love with. This 
H. Rowntree: sweet little lady, and yet, to her family, she can just crush you. So, it's this almost schizophrenic personality that you're living with, that other people do not see, or it doesn't distress them like it does when you live with it every day.

I don't know that that's very important. [Laughs] We've survived and--

Natural Jealousies

Levenson: Have you, over the years, been jealous?

H. Rowntree: I think I have been. I wasn't willing to face that till just recently. Yes, jealous because I couldn't understand this power she has over people. How she can have them slaves at her feet, and yet I know what she says about them after they leave?

Let me give you another example of this distress. When my children were teenagers, you know how difficult the relationships between Mom and sons and daughters are at certain ages-well, these children adored their grandmother and came down here quite often with their sleeping bags. They would pour out their troubles to her; she's a good listener--even I did in the early years.

She would always say to them, "We11, you'11 never amount to anything until you get away from your mother. You've got to be free. You'll only be free if you just get up and be free. Get up on your hind legs and do it." When you say this kind of thing to fifteen-year-olds [questioningly], it's a little difficult for the parents.

But young people loved her--they always have loved her-they love to come here. We've had, even since I've lived here, many, many young people come and stay. I'11 tell you one story in particular that amuses me and yet it shows the disparity in thinking between this woman who preaches freedom and the young people who interpret it differently than what she is actually saying.

This young lady was going to the University of Santa Barbara--California at Santa Barbara--studying botany. She used to come here a great deal. In fact, she even offered to stay here while we went away, because she was so fond of Grandmother, and she loved the hills. 
H. Rowntree: She was living with a young man and making no bones about it-talking about it freely--and Grandmother talked to her about it, and we all accepted it. One Friday night the phone rang, and it was Joan. She said, "Bob and I are going to San Francisco. May we stop overnight with you tomorrow?" I said, "Of course you may. Love to meet Bob. Come on."

Saturday morning I was making the bed in the guestroom, which happens to be a double bed, getting ready for Bob and Joan. Grandmother came padding out and she stood there in the doorway and she said, "Where's Bob going to sleep?" I looked at her and I said, "Well, I don't really know. Why?" "Well," she said, "can't he sleep out on the deck?" I said, "Nanniesther, I don't think that's any of our business. You know they've been living together for two years. What's the problem?" "We11," she said, "maybe that's all right, but not in my house!"

Planting the Bulbs by Lamplight: "We've Gone Common, but at Least We Have Color."

Levenson: Tell me about how you set up your gardening schedule. You started to tell me yesterday.

H. Rowntree: You really want that story? [Laughs]

Levenson: Yes.

H. Rowntree: Well, as you can imagine having seen the house and having seen pictures of the old house, this thirty thousand dollar construction project destroyed a major part of the lower garden. In order to accomplish the building we had to move Grandmother out for three months. Fortunately, our neighbors went to Europe and gave us their house. We made Lester promise that she wouldn't come over here until it was finished.

Before we moved her out, we went over the garden with her, and she pointed out the things that she felt were precious and that we should make an attempt to save. Which we sincerely did. We transplanted everything we could. We put stakes about everything that we couldn't transplant. We sincerely tried to save everything, but there was a great deal of damage.

When we moved back, she was then eighty-eight and still able to get out and do some gardening. Of course, she could hardly wait to restore the garden. She felt sure that I was 
H. Rowntree: going to be a willing slave, but I--in the very first day of our gardening experience--tried to make her understand that I was willing to do everything that I could, but I was not willing to give my life, as she had done, to a garden. I would help her restore what I could.

She liked to let the hose drip all night, you know. I was not willing to do it her way because I have worked with people all my life and done fascinating volunteer work, and $I$ was anxious to get back into this community and get involved with people. I love a garden but I don't want it to dominate my life.

I didn't think that it was quite fair for her to expect me to try to do what she had done. I couldn't! I didn't have the knowledge or the ability. She understood this but she still wanted that garden her way. So I worked with her for two or three weeks. Unfortunately, she was not able to get up and out into the garden until about 4:30 in the afternoon. And this was October.

Yes, I had been up at six in the morning, getting my husband off to work, house cleaning, laundry, cooking, and so forth and so on, and unpacking boxes. By four o'clock, I was a little bit tired. It wasn't a very pleasant experience. But I continued to work with her because I felt it was important.

However, on the day that we were planting bulbs at eight o'clock at night by lamplight, I gave up. I just turned to her and I said, "Lester, I can't keep this up. You're either going to have to get up earlier or you're going to have to make a plan and tell me what you want done."

Well, she couldn't get up earlier and she could not make a plan. So she said, "I guess you'd better just go ahead." So, on my first day of freedom, I had a ball. I had been carrying around pots of fuchsias and geraniums for two years, waiting for her to let us go ahead.

When we started to move her compost pile, she blew up and refused to go any further. She said that she couldn't do it.

We already had our house sold, we had our furniture in storage. So we rented a house. We decided if it's that important to her to keep things as they are, let's relax about the whole thing. So we waited two years until they closed our rented house because of the faulty septic tank, and we couldn't 
H. Rowntree: find anything else. Then we thought, two years is long enough; we've just got to go ahead, and so we did.

When I had to give up my own home, I couldn't part with my fuchsias and my geraniums and some of the things that I loved, so I potted them all and carried them around for two years.

So on my first day of freedom, I had a ball and planted them outside of my particular apartment downstairs. She came down at four o'clock that afternoon on a tour of inspection. She came upstairs and sank into a chair in a most dejected manner. I looked at her and said, "What have I done now?" knowing of course, what I had done, but wanting to see what she'd say.

"Oh," she said, "I am so ashamed. We've gone common." [Chuckles] I said, "Lester, what do you mean, we've gone common? Fuchsias and geraniums, and things of this nature, are indigenous to this Mediterranean climate. Why are you so upset?" "Well," she said, "everybody has those plants. I have always tried to keep this garden unique." And I said, "Well, honey, I'm sorry. But you told me the downstairs area could be mine, and I love them. They're in now and they're going to stay."

I was beginning to get on my high horse after three of four weeks of messing around.

About two or three months later, some botanists came down from the Academy of Sciences to have tea with her. She came down to the foot of the stairs to bid them goodbye. One of them turned around and looked back at my apartment garden and said, "Oh, how lovely your garden is!" She drew herself up in indignation: "It is not my garden now--it's Harriette's garden. We've gone common, but at least we have color." [Laughter]

So, you can see the adjustment was not easy for either one of us, but after ten years, it's been worth it.

\section{Health and Food Habits}

Levenson: I haven't asked you about Lester's taste in foods. I was so impressed, the first day we were down here, to see her enjoy that beautiful piece of corn you cooked for her. [Laughter] 
H. Rowntree: When I first inherited her, she supposedly had diverticulitis and was having a dreadful time with gas, stomach pains, and so forth and so on. She has been a great raw food faddist all her life, and she had a juicer here--she seemed to think that she just couldn't survive if she didn't have carrot juice made fresh every day--which was a terrible, terrible, chore. I was so relieved when that damn thing broke! [Laughter]

About four years ago, it finally blew up. I no longer had to make carrot juice because a new one cost about fifty-well, now they're up to seventy-five dollars. We just couldn't afford another one.

I took lettuce away from her almost immediately. She kept begging me to put it in a juicer--in the blender--and I tried that, but she still had a lot of trouble. I finally persuaded her that lettuce was not for her. She will never eat breakfast; she will never eat lunch. Her only meals are four o'clock tea, where she'll have cookies or cake and tea, and then dinner.

Dinner's as late as eight o'clock at night. I tried so hard to change this by getting food into her earlier in the day, and got absolutely nowhere. With indignation she said to me, "I know what my body needs. You don't know what my body needs." But here was a very miserable person, suffering unnecessarily from her faddish habits.

After she had her hysterectomy, for example, she felt as if she were losing all her insides. So she rigged up the most awful contraption of elastic and stuff, that she used to wear. She wore this for years, even in hot weather. She would just be drenched with perspiration with this miserable contraption to hold her insides in and wearing pants on top of that.

About eight years ago, I looked at her and I said, "Why do you wear that horribly uncomfortable thing? You're not the only woman in the world who's had a hysterectomy. Nobody else has to do this." She looked at me in astonishment. She said, "How do you know?" I said, "Most of my friends--I'm about the only one who hasn't had a hysterectomy. Nobody wears that kind of a contraption to keep their insides in." She threw it away and she didn't wear it ever again.

Levenson: Wasn't that wonderful?

H. Rowntree: But all those years of suffering?

Levenson: Poor soul! 
H. Rowntree: Why? It makes me sick.

Anyway, she made so much of her own misery just by this kind of thing. I expect she suffered dreadfully after the hysterectomy from the lack of hormone balance. Most women are given hormones afterwards to correct the imbalance. She was not given anything. She suffered agonies with hot flashes-for a person who's prided herself on good health, her health was miserable.

Levenson: Yet, there she was, walking at twelve, fourteen thousand feet--

H. Rowntree: Yes, but you don't know how many times she lay down.

Levenson: Really?

H. Rowntree: Right. Because I've been on many trips with her. That's one reason why I never would let her take the boys alone--because she could not hack it. Anything she made up her mind to do, she would do, no matter how hard it was for her. But the price she paid at the end of the day was terrific. This is one reason why I wouldn't let her take those boys alone. The one time that I did, they all came home complete wrecks.

Levenson: This is really interesting to me because, in her writings, sure she mentions hardships sometimes, but there's such a joyous tone she manages to put on the page.

H. Rowntree: Right. She got enough back out of it to endure the hardships. And she endured the hardships with pride. She thought it was the most wonderful thing in the world to jump into an ice-cold glacial lake and endure that kind of thing, just for the sake of enduring, I guess.

Levenson: This reminds me. I'm glad we're going on talking; then we can put everything in order. You tell me that for years and years she didn't get up till quite or very late in the day. But in her writings--and Jim Roof, for instance, told me that she never let the sun beat her up on her trips.

H. Rowntree: That was early on.

Levenson: In the thirties and forties, would that be?

H. Rowntree: Yes. I don't know. I'm trying to think about age. You see, I wasn't closely associated with her until she was in her late sixties. I never knew her intimately earlier. She came on a visit when we were on our [fire] lookout, up in the woods-- 


\section{Levenson: Where was this?}

H. Rowntree: Cedric joined the CCC [Civilian Conservation Corps] in the Depression, just before we were married. After we were married--he went AWOL [absent without leave] to get married on Christmas day. Our first job was in the siskyous, just outside of Crescent City. She came to visit us while we were there, with a friend. She didn't get up early then. Now, that was in 1933 or ' 4 .

Levenson: We11, she'd only be fifty-five then--fifty-four, fifty-five.

$$
\text { You said to me that there were some things you wanted to }
$$
add.

H. Rowntree: Yesterday, when you asked me about Lester's eating habits, we digressed. I thought maybe for the sake of complete knowledge, it might be interesting for people to know, since she's lived to be nearly a hundred, what kinds of food this little woman ate.

When she was on her trips, I know that she took every kind of dried fruit that she could get her hands on. In her day, there weren't the wonderful things that they now have for High Sierra pack trips. It was limited to dried figs, raisins, dates, apricots, prunes, and sometimes apples, but she didn't like raisins very much. She had always lots of nuts, and she always took a supply of bananas which she hoped would get dead ripe, because she would never eat them unless they were. They had to be almost mushy. And oranges.

I would presume that on any kind of a time when she was going to be very far away from water, she had canned fruit juices--but I never saw her drink any. [Laughter] I have never seen her drink very much of anything, really, except tea and juices. I've never seen her drink a glass of water. So, I just don't know where her fluids came from on those trips, but I know that at home, she always had lots of cranberry juice and pineapple juice. We always have had to keep a supply of those on hand.

Then, I know that she has never been much of a meat eater. Even today, she won't eat beef or lamb. She'11 eat chicken and fish. I don't think it's necessarily because she was a vegetarian. She just doesn't like it.

I think that's about all I can tell you. Always whole wheat bread, of course, and fresh fruit when available. Way back when--as a matter of fact, the morning we woke from our 
H. Rowntree: wedding night stay in this little house, she had prepared for us a hot cereal of whole wheat, which she soaked overnight, then cooked for hours. It took forever to chew it. [Laughter] It was delicious; she ate a lot of that. But she never liked rice and she wouldn't eat potatoes by herself. She eats them now because Cedric and I love them, but she didn't have potatoes very often.

She grew Swiss chard and carrots here in this garden, but she gave up everything else, because it was too much of a hassle to fight the rabbits and the gophers, and have vegetables in her garden too. So she always had to buy or beg vegetables from other people. That's all that I can think of. I don't know whether that's contributed to her longevity or not.

Fresh Air and Hard Beds

H. Rowntree: Oh, did I tell you what a fresh air fiend she was?

Levenson: Yes, I'd like to hear about that.

H. Rowntree: She really is a terrific fresh air fiend. Her bedroom windows have never been closed in her whole life. In the East, they slept on sleeping porches. Ever since I've known her, she has had windows in her bedroom wide open. She always threw her bedclothes back and never made it until just before she went to bed.

When she came to visit us in Berkeley, this sort of disturbed the heating system because we had one of those old floor furnaces. Of course, she never closed the bedroom windows of the room that I gave her. In order to get the heat circulating in our house in Berkeley, we had to have those doors open in the wintertime. I would sneak in and close the windows when she was gone. The minute she came back, she'd throw them wide open! [Laughter]

She's also been a terrific lover of hard, hard beds. We even had to take the mattress off and put it on the floor in Berkeley when she came to visit, because she insisted on a hard bed.

When she visited my son and daughter-in-law in Eugene, they had to take their mattress off and put it on the floor. [Laughter] She has very, very strong feelings about the needs of her body and she sees to it that they are achieved. It made it a little difficult to have her come to visit. 


\section{"Hell Itself Will Yield to Industry"}

H. Rowntree: She had to rest a lot. I think the only way that she managed to handle these excursions was by the fact that she was alone; there was no pressure on her. She could do it in her own time, you see. If she got exhausted, she could rest.

Levenson: She says--I think it's in Flowering Shrubs--she carried a note with her saying "Hell itself will yield to industry."

H. Rowntree: She's proved it. She's proved it. She surmounted her physical frailties, as many others have, and overcame them. The rewards were great enough to make it worth going over and over again. That's it--the perseverence, the drive, accomplishing the objective.

One of our trials and tribulations with her--we went on two camping trips with her because we were so poor, we didn't have a car. She had this big station wagon--the boys were, I think three and six--on these trips.

We, of course, would swim and hike, but she would always insist that now we'd have to take the Christmas picture. I can remember once, when we were camping near Mount Lassen, we had to have Mount Lassen as the background for this picture, and we had to go when the light was just right in the morning.

We were aroused at seven. She insisted that we get up there on the slope of this mountain by seven o'clock in the morning, breakfastless, to get a Christmas picture of the family. She had a camera with a tripod and black cloths, and a light meter--it just took hours before the was ready to take the picture. Here we were, with two starving, hungry boys, and a hungry husband, and a hungry Harriette [laughter], patiently sitting on the side of the mountain, waiting for this woman to take our Christmas picture. [Laughs]

This happened three years in a row, and after that, Cedric and I decided we'd do our own Christmas picture. [Laughter]

But those camping trips were worth it. She contributed a lot, I think, knowledge of nature and things of this kind--to our children. Our daughter has said that the things that she remembers about Nanniesther are the wonderful stories she could tell about gypsies, and Indians, and animals. She loved to hear Nanniesther's stories. 
H. Rowntree: If her [children's] books had had those kinds of stories in them, they'd have been just priceless. But, they weren't to be. Potboilers instead--moneymakers.

Levenson: That's what she said.

H. Rowntree: Which spoiled it, I think. Well, Rosemary, what else?

Levenson: Why don't we give you a rest now, a little stretch?

H. Rowntree: I'm not tired. I just want to get it over with. [Laughter]

\section{A Gift for Flower Arrangements}

H. Rowntree: One of the other things, perhaps, that might be interesting to you is her great love of flowers, not just for growing in the garden but for picking, and decorating the house, and taking to friends. She never came to visit us without the car full of cans of water filled with whatever was blooming in her garden.

This was particularly true at Christmastime. She would arrive about two days before Christmas with the car just full of greens and narcissus, which always bloom here at Christmastime. But she would never decorate the house until just about an hour before I had dinner ready to go on the table. [Laughter]

Levenson: Why was that?

H. Rowntree: I think she felt the flowers would stay fresh longer if they were left in their cans on the back porch. I, of course, wanted the house ready for guests long before dinner was on the table. It got to be quite an issue with me. Finally, after about five years, I persuaded her, please can't we have the decorating done before Christmas Eve this year? And she did. I should have said something long before I did. I just was a daughter-in-law who didn't have much courage.

I finally learned, though, that she would understand if you made it clear that this bothered you.

She did a beautiful job of arranging flowers. Her bouquets were exquisite.

Levenson: What sort of tradition of flower arrangement were they in? 
H. Rowntree: Informal. She taught me to arrange them. She said, "Now put them in and then stand off and look at them. Then take half of them out." And it worked!

Levenson: What did she use for holding the flowers?

H. Rowntree: Frogs and wire and things of this kind.

She used to do a number of arrangements for garden clubs and flower shows. She was a judge at many flower shows. She tells about the judging at some Los Angeles flower show when she came upon this lovely arrangement of baby blue eyes in a very simple vase. She said to the man who was taking her around, "Who did that exquisite thing?" He said, "My secretary." She said, "I want to meet her." She was introduced to her later and they became very, very firm and fast friends, and are still.

That's about all that I can remember now that might be important.

Lester was like that. She befriended all sorts of people, as well as being befriended by them. She used to gather clothes from everybody that she could think of and take them to Indian people that she'd met on her collecting trips--and the poor miners, people like that.

She was writing an article on this one time when we were camping with her at Bass Lake. At that time, I wore jeans and my hair was straight and long. I probably looked like today's hippie. [Chuckles] She made me pose for a picture. I still have the print and I look just exactly like a poor, worn-out, harassed miner's wife.

Levenson: She was going to use this?

H. Rowntree: An illustration in an article on one of her collecting trips about the people she met. I don't think it was ever published. [Laughter]

Lester's Changing Feelings on Death

Levenson: When I called you the other week, you told me that Lester had had a very interesting conversation with a minister about death. 
H. Rowntree: Yes.

Levenson: I would like to know what you can remember of that and what you think her feelings about death have been, at least for the past ten years, since you and Cedric moved in to live with her.

[Machine turned off briefly]

H. Rowntree: Lester's views on death have been developing over these ten years that she's been trying to die. I think they have changed from year to year, depending on what has been read to her, or who has been here and talked with her about this. I think it's been an evolving process.

After she fell and was hospitalized and begged to come back to the Hill and die--

Levenson: A month ago.

H. Rowntree: - -a month ago, I think that that experience perhaps crystalized a lot of what has been evolving over these ten years. After she had been home about three or four days, I was concerned as to whether or not she was fearful of dying, because when a person's been trying to die for ten years and can't, you wonder if they really do want to die, or if they're afraid of dying and are hiding it from you, and therefore are continuing to live even when life has nothing left.

I have a very dear friend with whom I grew up, who lives here in Carmel. She has a friend who is a minister in a community church. He was visiting at the time that I became concerned, so I called her and asked if she thought that he would mind coming up and talking to Lester since he is a counselor and has been counseling people dying of cancer and that kind of thing. I thought perhaps he would be the ideal person to bring out this fear if it existed.

He was with her an hour and had a delightful time. They related to one another, and she was very bright and alert that day. The little that I remember his saying afterwards is this: that there is absolutely no fear. If there was any, it's now gone--that she longs with all her heart to go. She feels there's a reason for her not being able to go--that something is unfinished and that only time will disclose what this something is. She has no nightmares about dying. She feels perfectly at peace.

We feel pretty sure that she does because we don't think that any person who has any kind of fears or tensions can lie 
H. Rowntree: as peacefully in repose as this woman does for hours and hours and hours. Because she is not able to read. She refuses to listen to mechanical devices such as the tape recorder for the blind. She no longer enjoys her music.

It's only when someone comes to visit who has time to read to her or chat with her that she has any diversions at all. Cedric and $I$ are not able to read to her because she does not feel that we pronounce the words correctly. I tried reading to her many years ago when she was ill, and $I$ was stopped about every other word because I was mispronouncing the word.

I finally threw down the book and said, "Lester, I can't take it. I'm sorry, but I just can't take this needing. You may think this is the way to pronounce a certain word, but I have been taught differently, and I can't change now either." [Laughter] So we finished our reading and she accepted this. Cedric has never tried to read anything but letters to her.

She's a well-educated person, even though she has only a high school education. She's well read. I think that almost anyone, in talking to her, would automatically assume that she had a college education. But she is self-educated. And she wants us to be as perfect as she is, and we don't care that much. [Laughs]

\section{Planning for Old Age}

Levenson: You told me, over the telephone, a story that moved me very much--after she had her fall and came back and she asked your husband who was going to look after you and Cedric when you needed it.

H. Rowntree: Yes, and she said this to me just the other day when I was getting her ready for your visit and trying to finish her bath. She was so exhausted, and turned to me and said, "Who's going to take care of you? You're going to be old some day. Who's going to take care of you?"

This is a very hard and difficult thing to answer. But I said to her, "Cedric and I hope that we will not put off the planning of our old age as you did. We tried to get you to think about this when you were in your seventies. You told us in no uncertain terms that when you could not drive your car any longer, you were going to die. You've been trying to die for ten years. Now you must realize that the power to die is 
H. Rowntree: not in your hands. Cedric and I have learned from you that if you don't plan a future for your old age well ahead of the time that you get into it, and are no longer able to handle it, your family are going to be stuck with taking care of you."

She said, "Well, why didn't I do this?" I said, "You let it go too long. By the time that you realized you could not die as you willed, it was too late. You could not make the emotional effort or the change." She said, "What are you going to do?" I said, "Well, we're thinking very seriously about retirement homes. We do not want our children to have the care of us when we are older." We think that everyone should look at this business of aging and the keeping of a family homestead so the children will have something as against the care of you as older people. Now, this is what it boils down to in a family who don't have very much money. We have here a valuable piece of property which everyone in the family loves, but the family is going to have to decide how much they love this piece of property as against how much they love us and want us properly cared for, rather than having to do it themselves the hard way in order to keep the property. This is what it boils down to in any family.

I feel very strongly, watching what's happening around me--my friends who have retired as we have and who have senile old mothers or old fathers to care for, and therefore can't do all the things they dreamed of doing when they retired, nor can we. When I look around, I feel very strongly that we're all making a terrible mistake in not facing up to what today's old age is. We're all living longer but we're not living, all of us, in good health.

Lester's Stay in a Convalescent Home: "A Growing Experience"

H. Rowntree: This experience in the convalescent hospital with Lester was a very sad thing for all of us. We feel that it was a good growing experience for her to see how terribly incapacitated others around her were. Senile ladies with their teddy bears. People who were in wheel chairs who were trying constantly to get out. Just to spend even half an hour in a convalescent hospital is a heartbreaker.

Levenson: I think it's remarkable that when someone's ninety-nine and a half, they can have a growing experience!

H. Rowntree: I feel she's had a growing experience. I feel that she did. 
Levenson: How's it show now?

H. Rowntree: She said to me the other day, when I said to her, "Lester, this business of your bath is exhausting you. Wouldn't it be better to go back to Beverly Manor where you had such tender, loving care? I can't give you the care they gave you. They took marvelous care of you. You didn't have to make all this effort and exhaust yourself."

"Well," she said, "anything that will make it easier for you." Never have I heard one word, nor has Cedric, of making it easier for us. So I feel that she grew. Her doctor was so distressed when he had to take her out of the hospital and put her in the convalescent hospital. I said to him at that time-he is a Catholic and his religion is entirely different from ours--but I said, "Tom, please stop bleeding. I feel strongly, and so does Cedric, that Lester needs this growing experience." I know that I'm right because she has grown.

The Cyanide Pill

Levenson: You told me yesterday about your experience in cleaning out her storeroom. Would you tell me that story again?

H. Rowntree: Twenty years ago, when she began to realize that she probably should not live alone too much longer, she asked us to help her turn what she called the chuck room (where she stored everything that she didn't wish to throw away) into a room and bath, so that someone could come and live with her.

We agreed with alacrity because we could see that this might be a possible answer since we couldn't get her out of the house. She wouldn't consider doing anything but stay here to die. I, of course, was stuck with the job of getting rid of a room full of throwaways. It was a terrible job. You couldn't even walk through the room because she'd never thrown away, as I say, as much as a paper bag or a pin.

She went merrily off to spend three months on the desert with her dear friend [Josephine Jackson] and I was left with the job. I went through everything, and of course, there were voluminous notes left all round--don't throw this away; don't throw that away; this goes to the Academy of Sciences, and so forth and so on. I followed these instructions meticulously. 
H. Rowntree: There were many things there were no notes on, and I knew very well that they had to go. Among this box of cast-off vitamin pills and therapeutic foods, I found an envelope, and across the front of it was marked, "SAVE! Suicide pil1--do not destroy." I opened it and here was a cyanide tablet.

Then I remembered that several years before, our dear friend Betty Hillman was dying of cancer. But she couldn't handle it and, somehow, found or was given a cyanide tablet and took it. Before she died, she gave another one to Lester, saying, "Now look, if this happens to you and you can't take it, this is quick and easy." And Lester brought it home and put it in the chuck room.

After several years when she found she couldn't die when she thought she could, she asked me if I had seen her suicide pill when I cleaned out the chuck room. I said, "We1l, yes." "What did you do with it?" I said, "I threw it away. It was five years old and it might not have worked." "Well," she said, "I don't think I would have had the guts to take it anyway. I think that what you don't finish in this 1ife, you have to finish in the next. So there must be some reason why I can't die."

\section{Unfinished Business}

Levenson: On that subject, you told me that her grandson, Lester, told her that she had unfinished business.

H. Rowntree: Do you have to go into these family ghosts? [Laughs] She was addicted to sleeping pills. She's an insomiac in the first place, and had been, I guess, for many, many years. When she was doing her lecturing, she was suffering agonies because she couldn't sleep. I'm sure it was nerves. We all have nerves when we have to speak in front of a group, but she couldn't handle it. So some doctor in Los Angeles got her started on phenobarbital as a sleeping pill. I belleve it saved her life in this respect, because at that time meditation was not being used except by strictly religious cults. Doctors were giving sleeping pills and tranquilizers as the only palliative they knew for people who were suffering like this, and she was completely hooked on phenobarbital and Amytal.

That was one of my first problems because by the time I inherited her and had to live with her, the phenobarbital had 
H. Rowntree: turned on her so that instead of putting her to sleep, it was stimulating her and she'd be roving all night. She would not follow the doctor's instructions. He said, "You know, this has turned on you. Let me give you something else." She would not have anything else. So we went through a very bad time. [Dogs barking]

During this period of time, when she was taking the phenobarbital, she was still trying to die but she couldn't pull it off, and she kept talking about this all the time. "Why can't I die?" Her grandson, who is Lester Bradford Rowntree, was working toward his doctoral thesis. She flew up to Eugene to visit him and kept them awake all night long because her phenobarbital wouldn't put her to sleep.

She said to him this particular night, "Why can't I die? Why can't I die?" He looked at her and said, "You're too wicked to die." She said, "What do you mean, I.'m too wicked to die?" He said, "You've got a lot of unfinished business. You have to think about your relationships with people." "What do you mean?" He said, "Well, take Mom [meaning me]. You never liked Mom." She said, "Why, I've never said a word to anybody about your mother." He said, "You don't have to. It's there. You've got to get rid of these feelings about people before you can die. You've got some fences to mend."

But that wasn't quite fair of my son. I think he should have elaborated. I don't think she realizes that she hurts people in the way that she does.

You asked me if I was ever jealous. I think I was because I couldn't understand the way people worshiped Lester--I couldn't understand this devotion. But then, they didn't see the other side of her. So I had no reason to be jealous, really. [Laughs]

Levenson: One doesn't need a reason.

H. Rowntree: I suppose not. But I think that one of the great rewards, in addition to the beauty, is meeting the people who have come here. And so many of them have become my (Cedric's and my) good friends. We have visited some of them. They have extended to us much of the love that they give to Lester.

So that has been a reward. It's just silly to be jealous. I've never really faced up to that, Rosemary, but it crossed my 
H. Rowntree: mind: when you said, "Are you jealous?" I think I have been. [Laughs]

Levenson: You're very honest. 


\section{INTERVIEW NOTE}

Rowan Rowntree: Lester Rowntree: A Totally Integrated Person

Rowan Rowntree was the last member of the Rowntree family to be interviewed. The title of his interview, "Lester Rowntree: A Totally Integrated Person" sums up a function of his recollections in helping to bring into focus and to integrate the images of the diverse Lester Rowntrees recollected by other family members. When Rowan describes his experience of killing a blue jay, close to his grandmother's garden, the story exemplifies the hold Lester held over the imaginations of her family. "What [the experience] did, it proved, in a way, that there was a truth in what my grandmother was trying to teach me about pacifism, about respect for animals, about suspicion of our technology. There was not only a truth in it, but there was some mysterious power in it. I knew I was doing wrong and I was punished" (p. 170).

We met on October 19,1978 , in an upstairs study in the Rowntree house in Carmel Highlands. In spite of the pressures on Rowan--in 1978, he had become Project Leader in the new Urban Forest Research division of the United States Forest Service while continuing to teach at the State University of New York, Syracuse--we had been in correspondence since May, and I had been helped by reading transcripts of the interviews he had recorded with Lester in 1969 and 1971. (See appendix II) Rowan's crowded schedule made the interviewer's trip to Carmel necessary, which effectively combined business and pleasure. The portrait of Lester which forms the frontispiece to this volume was made by the interviewer on the following day.

We talked in an upstairs study of Lester's house. As Rowan says, he had prepared himself for the interview by strolling through the garden his grandmother had been shaping since 1931. The interview was transfused with the ambience of Lester's home and garden. The transcript was edited and returned with careful notations by Rowan, mostly representing rephrasings and tightening of the complex ideas and feelings he expressed about his grandmother. His final written note on the question of amateur and professional status bears repeating. "One starts as an amateur, even with university degrees. And Lester became a professional in the way I think each of us would like to. The continued pursuit, the standards, all in order to find what's going on out there in the real world. She was intimate with her world, and she had that wonderful capacity to communicate that intimacy and knowledge to those who were interested" (p. 185). 


\section{The Rowntree Tradition}

Levenson: It's a pleasure to meet you, Rowan, after hearing about you so much. Perhaps you'd start by telling me briefly what it is that you're doing now and then we can go on to talk about your grandmother.

Rowan

Rowntree: I'm presently Project Director for the [U.S.] Forest Service Research Program that deals with urban forests and associated vegetation in terms of their ecological effects on the condition of human beings living in the city.

Levenson: That sounds very much in the tradition of what Lester was trying to do, except that she was working in the countryside.

R. Rowntree: I think she wanted to work wherever plants and people came together. She had an aversion to the city as she conceived it. I've never been sure how she did concelve it, but indeed she worked at arm's length from the city. She drew a lot of her energy--a lot of her love of the country and the wilderness --from this aversion to the city.

Fundamentally she was interested in using plants and trees, to enhance the quality of life where people live. In that sense, I continue in the tradition she inspired. One difference. She could create a wonderful garden, a fine landscape. She was an artist and craftsman; a practical ecologist.

\section{Early Memories}

Levenson: What are your earliest memories of her? 
R. Rowntree: My memories go back roughly to the year of 1939 when my younger brother, Lester, was born--when Mother, Father, and I were living in the village of Carmel.

There was this place called "the Highlands"(where Lester lived)alluded to time and again, and soon--as I remember--we began going to the Highlands. The Highlands was this house where we are now--this property. There was always a sense of anxiety, not altogether unpleasant, whenever a trip was planned to the Highlands. In part, this may have been generated out of the sense of obligation that Dad felt to come out and help his mother with the many, many chores in the garden and around the house--and the anxiety my mother felt toward her mother-inlaw.

My own personal anxiety was that there were never many places I could play--here. I had to be very careful of the plants and of where I walked. I had to be careful--I found out also--of rattlesnakes. I'm told that $I$ was nearly bitten by a rattlesnake flushed out while Dad was clearing a section of native brush for Lester's garden.

I was reprimanded many times for digging holes and I was instructed to be careful of this and that. These instructions were part of a continuing effort by my grandmother to educate me.

Levenson: Educate--you said that with a tone as though it were painful-was $1 t$ ?

R. Rowntree: It was. And it remained painful for many years.

Levenson: What made her education of you--or attempts at education-so painful? Was she sarcastic, as many English are?--and I'm speaking as someone who was born in England. Much of the bringing up of children is done or was done when I was a child, and I'm sure when Lester was, with sarcasm. Putting people down. Was there any aspect of that in what she was doing?

R. Rowntree: Yes. [Reflectively] It was the style with which she instructed us. We always felt inferior to her--there's no question about that. I don't really know if $I$ can add anything to that. It's a good point. It strikes right where it hurts in terms of the past.

She was never heavy-handed unless we made a real blunder. I remember an incident during my late high school years. I did part-time jobs as a gardener. In my last year of high school [Berkeley], I was privileged to work for Professor Emeritus Ralph Smith (UCB) in the Elmwood district. 
R. Rowntree: He, I think, hired me because he knew my grandmother--only to learn I knew very little about plants. My first job was to weed a particular seed bed. He pointed out the weeds and he pointed out the seedlings that he wanted to preserve. Then he took me off to show me some other chores, and by the time I got back to this particular seed bed, I'd actually forgotten which was which. So I mentally flipped a coin and started going at it, only to find at the end of the chore that I'd pulled out all the seedlings and left all the weeds. Professor Smith was very kind. He came back and he looked at me and he complimented me on my consistency! [Laughter]

Lester, on the other hand, would have had many things to say--not gentle at all. I came down to the Highlands, after my senior year in high school as a landscape gardener, thinking I knew pretty much about what was going on in the garden, only to find that no, I didn't, and I wouldn't be allowed to demonstrate any expertise by Lester or by the spirits who always seemed to govern my activities on this place.

One day, I was instructed by Lester to go under the compost pile and dig out a section that she could use for her arctostaphylos seedlings. Well, her compost was quite large. It was a good five feet high by four feet across.

One went into the lowest stratum as a coal miner would go in, tunneling, cropping up. I was three-quarters of the way under when a section caved in on me--nothing dangerous, of course--it wasn't that heavy. But I came out with leaf mould, bits of old canteloupe rinds, coffee grounds--I don't think really there were any coffee grounds--I suppose they were tea leaves--down my neck.

I thought I was deserving of at least an apology on her behalf [laughter] or some smoothing of my feathers, but she conveyed to me, rather, that I was incompetent in getting the compost out.

She was difficult, yes she was difficult--delightfully difficult. Sarcasm--yes. Good old English sarcasm.

Levenson: It's a bitter tool to use with children.

R. Rowntree: It's bitter because one can't respond to it. It was only later that I learned to respond to my grandmother--to carry on what I considered a dialogue of parity--where we were somewhat equals--which really only occurred when I returned to graduate school--in 1966--to pursue my--work full time. 
Levenson: When you were over thirty?

R. Rowntree: Yes, just about.

Death of a Steller Jay

R. Rowntree: I remember a sad episode but one that was very important to me. I needed at age ten or eleven to have some "masculine" activity, so $I$ asked for and actually received a $B B$ gun. I remember bringing it out here, knowing very well I would be run off the place by my grandmother.

I don't know whether we ever confronted one another over the gun, but I quickly got off the property as soon as Dad and Mother were directed to their various chores, and I went down near the Heisler place, found a Steller jay in a tree that was giving me all sorts of advice on what I should and shouldn't do in his area, decided I would shoot him-not really shoot him dead but just shoot at him as hunters must do.

I was unlucky in that the pellet hit him in the head and he fell directly down on me--and grabbed onto the front of my sweater and thereon went through his death throes, lasting around five minutes. It seemed as many hours to me.

I recall throwing my gun away. I recall appealing to God for forgiveness. It was terrible. It was terrible at the time because there were so many emotions wrapped up in that experience. I was confused about whether I should appeal to my God or to my grandmother's God--the spirit or spirits that seemed to reside here. (I came to find, much later, our Gods were one and the same.) What it did, it proved, in a way, that there was a truth in what my grandmother was trying to teach me about pacifism, about respect for animals, about suspicion of our technology.

There was not only a truth in it, but there was some mysterious power in it. I knew I was doing wrong and I was punished. So I thought at the time. But as I grew older, that experience came into better perspective and I realized that I was fortunate to have experienced such a profound event exemplifying the principles my grandmother lived in her life. So I came slowly to respect those principles. Slowly, as adolescents do. 
R. Rowntree: With regard to plants, I resisted tenaciously any commitment to botany and horticulture, although I love the out-of-doors and I love to be among native plants in their native habitat where they wouldn't mind so much if I walked on or near them; where I wouldn't be asked about their Latin names; where we could meet each other on our own terms and I could enjoy myself.

So the horticultural environment of this place--the elitism of my grandmother in terms of her botanical knowledge-really turned me off for many years. I guess I grew first in [pause] some opposition to her devotion to whatever it was she was doing.

It was only later that I realized what she was doing and all of the wonder and interest that $I$ had acquired in the out-of-doors--in the mountains, primarily--was now brought to bear on the choice of career.

Lester: Friend, Playmate, Philosopher, and Critic

Levenson: Just to fill in before we move on--what chores were Harriette and your father doing while you were shooting blue jays?

R. Rowntree: I shot only one blue jay. [Laughter]

Mother was moving about the place trying to keep me out of trouble, trying to keep Father pacified because he would work, I think, with some degree of anger. He had his own home to take care of and, yet, he had to be out here, working quite hard on the foundation of what became a magnificent garden. That is, clearing the existing vegetation, transporting the soil and rock here and there.

Mother never really trusted this place and well she shouldn't have--in reference to that snake episode when I was, apparently, almost devoured [laughs]. She was about--I don't know what she was doing.

Levenson: The way you're talking sounds very much the way one expects a son to speak of his father or a daughter of a mother--as though the generational revolt was going on between you and your grandmother--skipping a whole generation. Is there any accuracy in that? 
R. Rowntree: [Reflectively] That's very accurate, Rosemary. Quite perceptive of you, for it had never occurred to me.

It was probably because she was so important to me--she had such efficacy. She wasn't an idol. She was a curious, powerful, lovely, intelligent, principled person.

I've been stressing some what we might call negative things, but there are threads through all of the years--strong threads, perhaps dominant threads--where she would take my younger brother and me swiming, camping, hiking, strolling, running, playing. She had this endless capacity to play.

So on the one hand we talk of her as an elitist--as a person who had knowledge and ability and reputation. But, we spent hours and days with her following ants around, digging holes together, swiming, and pushing logs out in lakes. She taught us how to swim without bathing suits in the Carmel River --much to my mother's horror later.

She taught us how to watch birds and how to listen--to distinguish their calls. She taught us, and very easily I might add, as one child might teach another--not as an adult or a school master would teach his students.

So these were the positive bonds--and strong bonds they were. But one must seek one's own identity and she encouraged us to. She forced us to. How does one do it? You take what you see and you say, "Well, it would be too easy to succumb to that. I might as well try the opposite." That's the beginning of a sort of dialectic that has existed in my relationship with her. She provides an intimate and important reference point.

She was powerful that way--powerful because she was our friend and playmate--and philosopher.

Levenson: You speak of the elitism. By the sort of ordinary socioeconomic types of divisions one makes--her family was, at the most, upper middle class, the Cumberland family. Are you speaking of an intellectual elitism? Was it the possession of the Latin--the possession of Jepson's taxonomies in her head? What was it that made her an elitist?

R. Rowntree: It certainly wasn't socioeconomic. In fact, she despised any socioeconomic judgments in defining where people should stand in society. It was philosophic, it was intellectual, it was-trying to respond to your question--I'm not sure how much it had to do with her possession of knowledge. 
R. Rowntree: Plumbers possess knowledge. She did have a great technical competence, a vocabulary. No, it was not that. It was the fact that she was in touch with the universe that I think made her so respected in my mind.

She understood the kinds of things that ecologists work years to understand, I think--or did in the sixties, when we were talking about the web of life. She understood. She had an intuition that served her well. It served all of us well.

She also had standards--very, very overt standards of behavior, of thinking, of writing, and of professional and intellectual conduct.

I recall [chuckles] one of many, many incidents--I won't tell you them all--just the one where I was finally, I think, at a point in my career where I'd achieved a status. I was being interviewed on KPFA [Berkeley FM radio station] about my work. I was quite pleased that she was listening.

Several weeks later, I had an opportunity to come back down to Carmel to visit her. I waited for her to bring up the subject that she'd heard me on KPFA and when she did, she said that she thought it was okay, but that I had pronounced "environment" wrong. [Laughter] I'm sure I must have used the word many times. I had not enunclated it correctly--I had not allowed the second " $n$ " to come through in its full glory.

These were the things that perturbed me about our professional relationship. But these criticisms were not alien to me. My parents provided a home in which we had critical support--always critical and always supportive.

Lester, more than anyone else, had the standards of enunciation, of good writing. She gave me a copy of William Strunk and E.B. White's book, The Elements of Style, which has served me so well. She always thought that Americans couldn't write, that only the English could write.

Now there you have a cultural elitism I'm sure could be dispelled with any examination! But, it was delightful to have her persist in her personal view of professional conduct. [After pause, tape resumes]

Levenson: I wanted to ask you whether you think that any of this curious generational displacement, or whatever you want to call it, came about because Lester, perhaps, was disappointed in the accomplishments of CeJric, her son? 
F. Rowntree: Well, I would have to speculate on whether she was or wasn't. I really don't know. I think that she was perhaps unfulfilled in her son's choice of occupation. She was not "disappointed" because she saw the devotion, the standards, the excellent competence that Dad brought to bear on his profession. He rose to what we all considered to be the epitomy of work in that area.

I'm very proud of him. We all are. Just because he didn't become a horticulturist or a landscape architect, I can't believe Lester was blind enough not to feel a great sense of extension of her own standards of excellence and devotion.

Dad chose what he was always interested in. Lester would --from the very beginning--ask us to know ourselves to the extent that we could eventually make this choice--difficult choice, isn't it, for some?

Levenson: Oh yes.

R. Rowntree: She--from our earliest years--and in very different ways-coming at us from so many angles, she would ask us to know ourselves-- to believe in our intuition and in our interests-that they were worthwhile--that they were legitimate--and that they would sustain us, completely.

I heard these things as a young person and I said, "That sounds fine." And then it came time to do it, to really seek a profession--to seek to develop and implement an interest. It was not all that simple.

I chose to follow the pull of that dialectic view I mentioned earlier, to explore the opposite of what my grandmother had been teaching. Thus, I spent five years in corporate affairs before I realized that I was devoted to the natural world--to the importance of the natural world for human beings.

Once I confronted that, it was like falling in love with someone who had always been an important part of my life, but who had never been recognizable. It was lovely. 
Dreamer and Storyteller

Levenson: One of the things that astonished me about your grandmother is how she started her first career at fifty-three and then, when her eyesight started to fail, she became a successful author of children's books. I have heard that those children's books grew out of stories that she used to tell to her grandchildren. What do you recall about that?

R. Rowntree: As I remarked earlier, she was a fine playmate and she would take me and, later, when young Lester--my brother--was of age, three--four years old, she would take us both to spots-beautiful spots--whether they were far away or in the back yard. Somehow those spots became beautiful. We'd sit down, cross our legs Indian fashion, or lie and look up at the sky and the clouds, depending on what suited us at the time--and she would tell stories.

I can't remember those stories. But I think the children's books she wrote came as much from the experiences we had together as from stories that she told us.

I'll say that I haven't read those books for many years, but I remember when I read Ronnie and Ronnie and Don-Little Turkey--very familiar situations struck me.

As soon as we left this place [the Highlands], we were on equal terms with her. She guided us into the wilderness and into the out-of-doors as a colleague--as an explorer-comrade.

The situations I found in the children's books were very familiar because I think we experienced a lot of them together with her.

But indeed yes, she had stories for us--always stories-softly told--never exaggerated--always a good twist here and there--always a surprise--soothing, not frenetic--well done, really--well crafted stories. How she was able to weave these--spin these--verbalize these--I think speaks to something she has--a natural ability as a dreamer, an articulate dreamer.

She often went off as a child and explored the landscape, at the same time doing a lot of daydreaming. I like to do that myself--that's a wonderful thing.

Levenson: And it's a wonderful craft to be able to tell stories. 
R. Rowntree: I think it springs from the same source as her writing ability, although, I know, in fact, she was a disciplined writer.

I know that writing is hard work. It's truly a craft. It requires reworking, sanding off the rough corners. It's a lot of work for most of us. I wonder if she did it rather easily. I hope she didn't! [Laughs] If she did, I hope never to know.

Her Religious Influence

Levenson: You touched on the subject of religion. How much do you think the Quaker background was important to Lester at the time that you were growing up and getting to know her as an adult?

R. Rowntree: She, as I remember, was not a practicing, go-to-meeting, Quaker. She was practicing in the sense that she held to many of the tenets of Quakerism as I understand them.

She was a devout pacifist. She was not an egalitarian but she understood social service in the way that the American Friends Service Committee understands it--trying to make things better. She couldn't do it herself, but I think she always respected my mother for devoting so much of her time to improving the lot of others.

She did not enjoy attending Quaker Meetings. She would rather express her faith, belief and work here on the Hill. She passed on to me a faith in the universe, in a being I call God--that she called the "It Is."

She used to say that the Unitarians had it. When I moved to Syracuse, I joined the Unitarian Society there. While they do incorporate a lot of what I saw in my grandmother's religious beliefs, I'm not thoroughly satisfied because they seem embarrassed to talk about God, trying too hard to embrace the diversity of human opinion on the question. They try hard to understand, often with a pseudo intellectual energy that diverts them from any form of belief. My grandmother, on the other hand, saw no dichotomy of intellect and intuition. Her life was integrated, holistic and very effectively so. 
Rowan's 1969 Interviews with Lester

Levenson: About ten years ago, you talked systematically with your grandmother and you have been kind enough to give me copies of the transcripts of those conversations.* What were the circumstances?

R. Rowntree: The occasion for the interviews was a seminar I was taking, as a graduate student at Berkeley, from David Lowenthal, who is presently Distinguished Professor of Geography at University College, London. The seminar dealt with environmental attitudes and perception.

For a project, I decided to do something I'd always wanted to do, and that was to sit down with Lester and systematically plumb her memories and images. I wanted to try to understand what she brought with her from England, and the lenses through which she saw her contemporary American landscape. I wanted to know what values governed her perception of the environments in which she lived and worked--the Southwestern desert, the Plains, the prairies, the forests.

I would sit with her, mostly in this very room, often on the stairs outside the door to this room out on the flagstone stairs leading down to the little patio. It was a very special place out here. I'd get her out there and ask her questions, and after about an hour of this, I'd rush up to the little room where I had my typewriter and I would try to capture the phrases she used, although I'm sure I didn't, altogether.

Levenson: Did you ever try to use a tape recorder with her?

R. Rowntree: [Laughs] I chose not to because I was raised with the notion that she would never speak into a tape recorder. I just assumed that a tape recorder was out of the question. It was like bringing a gun on the property. I learned subsequently that others have tried and some have been successful.

*See Appendix II. 
Love, Jealousy, and Hard Whole-Wheat Bread

Levenson: There's something in these conversations that I would like you to comment on because I think it has some relevance to what we were talking about earlier.

In your 1969 transcripts, she mentions a very moving episode when she was a child. She said to one of her brothers, "I love you" and he scolded her and said, "You should never express your emotions like that and you should never wear your heart on your shirt sleeve."

Was she able to express love?

R. Rowntree: Oh, I think so. Not directly--not in that way. I don't think she ever told me she loved me, but then she didn't need to-she did so much for me otherwise. She told me, when we discussed that incident, that it had remained with her and she had found it difficult through her life to cope with that problem. I think she is a giving person--a very loving individual--sharing.

She would give so much to those she wanted to help, particularly young people--not in the family, necessarily. There was always a certain amount of jealousy on my behalf that she gave so generously to other young people.

Levenson: Gave what--?

R. Rowntree: She gave everything! She gave her time, she gave her car, she gave money, she gave books--she trusted everyone. So she had a lot of love to give. I think she loved children very much--she loved to see children grow up into independent beings. She, of course, would be additionally pleased if they grew up to love plants and wilderness--the universe.

But no, I think that this is what we were talking about earlier. She had oblique ways of dealing with emotions. If she was upset, she would not articulate this displeasure directly--it would be a snip here and a snap there and a cold shoulder to deal with. We got used to her. We never considered her a cold person--an unloving person.

Levenson: She could be very direct on paper. Your brother, Lester, told me about one or two quite harsh letters that he received from her. 
R. Rowntree: Yes. On paper. Particularly if she wanted to reprimand us. She figured, I think, that we were loved enough by our parents so that her job was to guide us, to criticize us in terms of our moral and intellectual development, including those skills that are the tools of the intellectual and the philosopher-and I don't use those labels with any embarrassment at all in this context.

The philosopher--as I'm using it now--is the one who deals with values and the nature of things at least in his or her own life. One who thinks about it, tries to understand reality to the extent that you're at peace with it--not always to analyze it, to reduce it, to systematize it, but striving to come eventually to a peace with the universe.

Levenson: Again, she seems to have been taking a parental rather than a grandmotherly role?

R. Rowntree: Absolutely. Lester took a direct role, though she never forced herself. She was just there. She was an attractive person and she was an active person.

She put on her blue jeans and her hiking shoes, and she was right there on the ground with us. As I say, we saw her as an equal when it came to doing those active things that boys do--or that boys and girls do as they grow up--they want to be outside and they want to understand about nature.

Levenson: Nobody has mentioned sports so far. I know one of her brothers was a distinguished cricketer. Certainly there's a strong tradition of sportsmanship and so on in England. Did play with her ever include a ball or some of the things that we associate with athletic prowess?

R. Rowntree: No, I don't think so. She often discussed her brother-was very proud of him. No, it wasn't from Lester, I think, that my brother and $I$ became very early interested in tennis. But she lent a set of values that supported an active, healthy, outdoor life. And those values included playing the game well and fairly.

Levenson: How would you--oh no, there's one more other question I wanted to ask you on the domestic level: what was she like as a cook? And what did she eat? I know what she ate out in the wilderness.

R. Rowntree: Lord! 
Levenson: But at home. Do you remember?

R. Rowntree: It didn't suit my taste at all as a young person. She couldn't cook a hamburger the way I wanted $1 t$. When we came out here, we were girded for nuts and fruits and dried this and parsleyed that, and I guess this is when I first came to appreciate [laughs] the green vegetables, plants, that she would give us.

I didn't like the nuts at all--didn't like the raisins that much. I didn't like the dried fruit. What I did like was the watercress and later on, when she had her vegetable garden, the many green vegetables she grew that were succulent and [whispering] just delightful!

Later on, she started making mushroom soup and I loved that--the best mushroom soup I've ever had. She would do a good chicken--good American food--but, boy, there were times when it was pretty rough.

She would get a whole-wheat bread that was so hard and so dry that one could barely get it down. Later, I remember she acquired a blender--an osterizer--that relieved us of much of the burden of this diet because then she would go into fruits -fresh fruits--bananas and things like that. It was rough for a couple of young boys who were raised strictly on American food.

Her Professional Contributions

Levenson: What would you say were Lester's greatest contributions?

R. Rowntree: I wasn't expecting that question. I was--

Levenson: Do you want to take a pause?

R. Rowntree: No, let me ramble. I'd like better to play with this.

I will respond to that, Rosemary, in what we'11 call the professional context. I might start with the observation that so many of the individuals who contribute to a particular field of interest or study, do so exclusively through their writings--through their pronouncements that appear in this journal or that book. Lester contributed something of substance--which I'II get to in just a moment--but I think a unique dimension of that contribution is that she contributed it as a person--as a totally integrated person. 
R. Rowntree: She was not an intellect floating off in space somewhere-disembodied--she was a shortish, tanned, full-cheeked, browneyed, sparkling individual. I think that for those who never met her personally and never saw a picture of her, they even experienced this vitality, this complete integration--in other words, there was nothing contrived about her.

It came through in her writing--the writing is good prose --it's damned good prose. It's the kind of writing I would like to do--direct, interesting, inspiring, not flowery, not convoluted--and carrying with it the interest, the devotion she felt for her work--the commitment--but comnitment is such a heavy word--I think interest is good enough.

If people came across her writings or were touched by her --many of them were--I think they sensed something more than just a botanical inquiry there. She put her whole self into it and $I$ do believe that it came through.

As to the substance, she of course, was interested in getting native plants introduced into the horticultural field. Remembering back to the days when she was practicing, Californians were flamboyant in their introduction of exotics to the state. Santa Barbara was a center of introduction of exotic plants.

She entered California, you know, in those days when gardens were riddled, rampant with exotic plants from all over. Also, gardeners were trying to--in many cases--reproduce the eastern American landscape, the landscape of the humid East.

She began looking at local shrubs--local in the sense that they were western and southwestern. She began looking at the ability of the semi-arid environment to sustain certain plants. She began looking ecologically at horticulture and landscape architecture.

Lester was not the only one who was doing this, but she placed value on native plants. That's saying something more than just the fact that you ought to use native plants because they'll grow better, take less water. She valued things that were natural--things that were in their place--things that fit. There's almost a teleological foundation to much of this in that things ought to be this way and ought to be that way. She thought she knew and, I think she did, what kinds of plants ought to be growing where. 



\section{CONSER VATION DA T A}

Compiled by

LESTER ROWNTREE

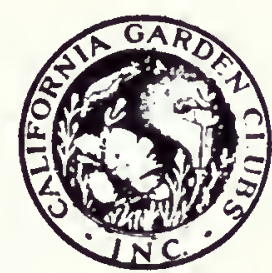

California Native Trees, Plants and Flowers Listed by Districts

\section{CALIFORNIA GARDEN CLUBS}




\section{INTRODUCTION}

D ISCOURSES (either written or voiced) on conservation are apt to be very dry. They are supposed to contain mony "don'ts" and they are usually well padded with lists. These columns of Latin botanical names seem formidable to the read. er, but there is really no way of avolding them. Comparatively few of our native plants bave common names. Tbe lists which accompany this article have been made up of those native California plants which have achieved distinction in various ways; by their conspicuous bloom; because of their rarity in California (althougb, like Cornus canadensis and Linnaea borealis, for example, they are common in ad. foining states); because they are distinctly Californian, even though they may spll over the borders a bit, as do Fremontia californica, Dendromecon rigida and Romneya coulteri; or because they are Californian endemics, as are many of the Ceanothus and Arctostaphylos apecies.

\section{Endemic Plants}

An endemic plant is one whose natural babitat is limited to a certain area or region. It may be a narrow endemic, auch as Arctostaphyios myrtifolia, which is found only in a few neigbboring places in Amador County; or it may be a broad endemic, which growing only in California, is found in scattered stands all through the state. Iris longipetala is an exam. ple of this latter group. One finds it along the central coast of the state at various points, but nowhere (as a native) outside of California. For further information about California endemics I should like to refer you to page II of W. L. Jepson's most interesting introduction to his "Manual of the Flowering Plants of California."

Forty per cent of our native plants are endemics. Many of them bave insignificant blooms and, if they were more common, would be called weeds. Only plants of real beauty (either of flower, follage or form) and of defuite garden value, are included in these lists, which bave been compiled as a means of drawing attention to those of our native plants which are worthy of appreciation and encouragement. In our efforts toward conservation, we must remember that it is the grazing of sbeep and cattle, the introduced weeds which are aweeping the land and driving the wiid flowers before them, the increase of agriculture and of real estate developments, and aome of the com. mercial bulb collecting, which are the chlef causes of the disappearance of the native wild bower. Some of these forcea are beyond our control. But the federated garden clubs can foster a knowledge and appreciation of those desirable native plants which grow in their districts and can take some steps to guard them from extinction. The wild flower refuge is the most feasible way to accomplish this end, and might efficiently be connected with the work done by the garden center.

\section{Native Bulbs}

Of all the wild plants, the bulbs are probably most in need of protection. The majority of our choice alpines (many penstemon species, for example) are tucked away, out of reach of most of the devastation. So these alpines, the annuais (which can take care of themselves falrly well), and the varieties of the main apecies given, bave been omitted from these already rather lengthy liats. It is a pity that there is not a federated garden club on the Santa Barbara Channel Islands to prize their famous exdemics wbich keep themselves 80 definitely off the majnland:-Lyonothemnus Boribundus; Quercus tomentosa; the two busb buckwheats, Eriogonum giganteum and E. arborescens; Antirrbinum speciosum and the other beautiful rarities. But any garden club district which commands a bit of Cailfornia's coast line will find interesting narrow endemics within its bounds.

\section{Educate and Legislate}

Seemingly, all native plants on the malniand are protected by a recent ordinance. Legislation is and will be necessary and valuable when applied to wayside flowers and to commercial collectors. It has done excellent aervice in belping to protect the cactus species, the snow plant, yucca and toyon. But no amount of legislation is golng to ave the wild flowers from the devastation wrought by grazing animals, and in any case conservation must and abould find deeper and more abiding channels thru which to work. Education which will achieve the recognition and appreciation of our native plants, intelligent, sane and well weighed local legislation which can be enforced, and finally and of great importance, wild flower aanctuaries are our means of approach. Conservation in its stricteat sense often defeats its own ends. The trend toward state-wide interdiction should be tempered by a general accepting and applying of common-sense rethods of local work with anctuaries for, after all, conservation is a matter of individual and conscience and of applied intelligence.

(We wish to emphasize that the following list is in no sense exhaustive.) 
District No. 4. San Francisco, San Małeo, Santa Clara, Alameda, Contra Cosła, Marin Counties. DISTRICT No. 9. Santa Cruz, Monterey, San Benito Counties.

DISTRICTS 4 and 9 are rich in endemics. Among others there are white Fritillaria liliacea, the pink-flowered rosette of Arabic blepharopbylla, Arctostaphylos pumila, to say nothing of the already known and appreciated Monterey Cypress (Cupressus macrocarpa) and Gowen Cypress (C. goveniana).

ABIES veausta. Santa Lucia Fir

ADIANTUM caplllus-veneris. Malden Hair

A. emarginatum. Calfornia Malden Hair

A. peduatum. Five-finger Fern

AESCULUS callfornica, Buck-eye

AWTUM dichtamydeum

ARABIS blepharophylla, Rose Creas

ARCTOSTAPHYLOS andormonil

A. hooker

A. pumila

A. sensitiva

A. tomentosa

AQUICEGA tracerl

BRODIAEA capitata. California Hyacinth

B. coronarta, Harvest Brodiaea

B. Ixloides. Golden Brodiaea

B. Iaxa. Ithuriel's Spear

B. pulchella

B. synandra

B. terrestris

CAIOCHORTUS albus. Fairy Lantern

C. caeruleus

C.Inteus, Yellow Mariposa

C. pulchellus. Golden Lantern

C. spiendens, Lllac Mariposa

C. venustus. White Mariposa

C. umbellatas

C. uniflorus

CEANOTHUS dentatios

C. Poliosus

C. Incanus. White thorn

C. Jepsonil. Musk Bush

C. ollganthus

C. papillosus

C. rigldus

C. sorediatas Jim Brush

C. thyrsifiorus, Blue Blossom

CHLOROGALUM purpuremm

CLINTONIA andrewsians. Clintonia

COREOTHROGYNE calleraica

CXNOAYOSBUAT sraado
CUPRESSUS goveniana، Gowen Cypress

C. macrocarpan Monterey Cypress

C. sargentil. Sargent Cypress

DELPHINIUM callornicum

D. cardinale. Bcarlet Larkspur

D. nudicule. Red Larkspur

D. nudicaule var. Inteum

D. variegatum. Royal Larkspur

EPIPACTIS gigantea

DIRCA occidentalls. Leatherwood

FRITILARIA biflora. Chocolate Lily

F. Lanceolata. Checker Illy

F. Llliacea. White Fritillary

F. viridia

GENTLANS, all species

IRIS macrosiphon

LESSINGLA ramulosa

LEWISLA rediviva, Bitter Root

LTIUM maritimum. Coast Lily

Lo pardalinum. Tiger Llly

L. rubescens. Chaparral Llly

UTTHOPFIRAGMA afinls. Woodland Star

MCCROMERIA chamissonis, Yerba Buena

MONARDELTA macrantha

PENTSTEMON condlfollos
P. corymbosus
P. heterophylius
P. rattanil

PINUS murlcata, Bishop Pine

P. radiata. Monterey Pine

P. tuberculata. Knob-cone Pine

ROMANZOFFLA sitchemsis

SEQUOIA sempervirens

SILENE callfornica

STANLEYA pinnata

TAXUS brevifolia, Western Yew

THERMOPSIS macrophylla

TORREYA callfornica. Californis Nutmeg

VICLA gigantea. Giant Vetch

VIOUA pedunculata. Yellow Pansy 
To be added to Hrs. Rowntree's Ilst if she approres.

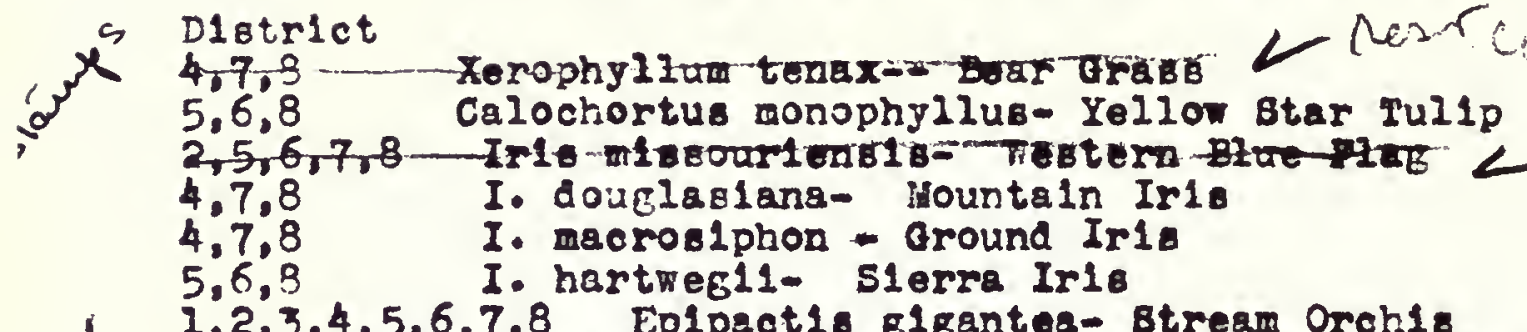

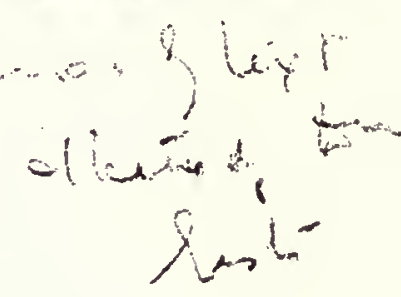

1,2,3,4,5,6,7,8 Ep1pact18 Elgantea- Btream Orch1:

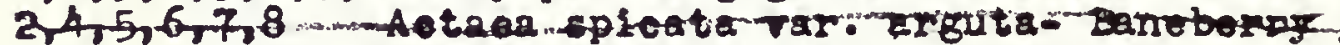

$1,2,3,4,5,6,7,8$ Aquilegia trunoata- Columbline

4,7

A. tracej 1

$5,6,7,8$

Calyoanthus oceldentalis- sweet Shrub

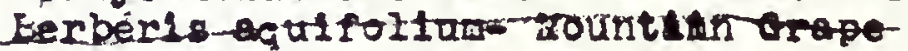

$1,2,3,4,5$ Dendromecon riglda- Bueh Popny

$4,5,6,7,8$ Oi:oentra-formoge Blooding-jest

$1,2,3,4$ Btinleya pinnate- Prince seather $1,2,5,6$ Ph1ladelphus Iew1 11 var. callfoinlea- Mock Orange

5 $1,2,3,4,5,6,8$ Carpenterla -aliforiloa- Carpenterla.

$3,4,7,8$ R1bes areum- Golden currant

$1,2,3,4,8$

$1,2,3,4$

R. eangulneum and vars.- Bloxerlng Curzant

R. malvaceur- H11d Curront

$2,3,5,7,8$

R. s peclooum-

F12d Gooséberry

Holodisous discolor Grea Dab

$1,2,3,4,5,6,7,8$ Photinia arbut1folla- Toyon or California Holly

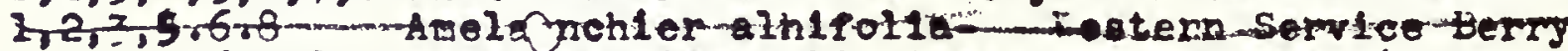

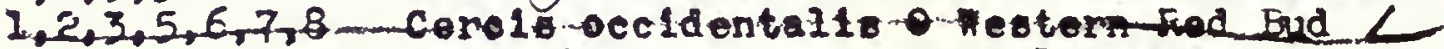

1

1,2

$1,2,3,4,5$

1,2

1,2

$1,2,3,4,5,6,7$

1,2

$1,2,3,4,7$

$2,5,6,7$

4,5

$2,3,5,6,7$

$7,2,3,4,5,6,7,8$

$1,2,5,6,7,9$

$1,2,4,5,6,8$,

4.5

$3,4,7$

$-1,2,3,4,6,7,8$

$2,5,6,8$

$2,4,3,8$

1,2

$4,6,7,8$

廿eptensta-etżata

$4,5,8$

1,2

$2,3,4$

2

2

1,2

$4,5,8$

$1,2,3$

$1,2,3$

1,2
Cerclolun torrejanum- Palo Verde

sldalcee amblgua- Aprioot Mallow

Fremont1e celiforniea- Flannel Eush

Fouqulerla eplendens- Ocot1lie

Uentzella Involucrata- Blezlne Btar

H. laevicaul1B- Blazine Star

H. trlousp1B- Desert Blazing Star

Zauschnerla ealifomlca- California nild Fuch $1 \dot{a}$

Z. IEt1rol1a

Garrja ell1pt1ca- S1lk Tabel Bubh

G. Irenont11- Bear Brubh

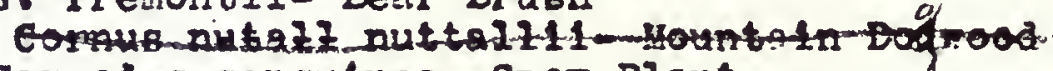

Sarcodes Banguinea- Snor Plant

Rho?dodendron occldentalo- Fosterm Azalea

R. callfornicum- Callfornla Foee Bay

Gautherla halion Edial

frbutu menz1e811-Madrote

Polemonlum occldentalo- Jacob' Ladder

Q17.1a aggregate-acarlet GIT2

Phacella minor- Californle Bluebell

Cynoglossum grsnde- Festern Found's Tongue

Kertensla olidata- Hertereter

Selzzarla mexloane- Bladder Sage

Sphaoolo calycina and vars. - P1tcher Sage

Lyclum pall laum- Rabblt Thom

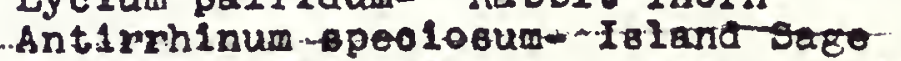

Hohavea confert1flora- Desert Liohavea

iilquius 16 1611-PInk wonkey-flezer.

Coreopels glgantea- B.sh Coreopils

C. marit1ma- Danth-o

Balleya mult1rad12ta-- Ba1leja 


\section{CALIFORNIA GARDEN CLUBS, Inc.}

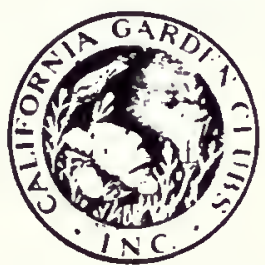

PRFSITENT

MRS, RICHALN KIRKLEY ti: South Serrano Ave I.x Angeles
March 18, 1937.

Dear Mrs. Rowntree:

I have received

this morning your letter of March 16th, returning the prfof, and all of the corrections w1ll be made as indicated by you.

We are replacing the sentence regarding the list being limited with the one you suggest. The lower case letter used for zdded species was an error on the part of the printer. Our copy carries the capital in every instance, and this will be rectified by them. I have no ldea why they used the lower case letter.

We are certainly very grateful to you for making these corrections, it is amazing how many errors crept in. Te will have a corrected proof submitted and $\mathbf{w 1 1}$ go over it very carefully before the article is printed.

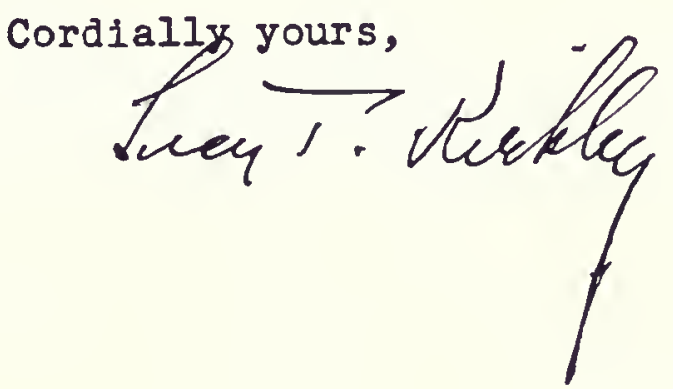


R. Rowntree: She had a great artistic sense. As I strolled through the garden earlier today in preparation for our interview, I was struck with how it's changed. I was struck with how I remembered it, as a very fine piece of landscape architecture. Low shrubs, native ceanothus, arctostaphylos--they were placed well. And the rock--the use of rock--the positioning of the trees. There are a few trees out of place here, but I've learned to accept them as she did.

The Torrey pine up at the back of the house--which has grown so magnificently--is completely out of place standing next to her Gowan cypress, which is, of course, a native of this area. Torrey is a native of California, but certainly not of this area.

Also, she brought many plants, many shrubs, to her garden--that are not native to this area. She introduced the Rhus integrifolia to the hillside here, and it's taken off! It's a shrub that I understand has been found growing profusely on many of the old Indian middens along the Southern California coast.

But I was talking about her artistic grasp of the correct distribution of mass and color--although there is not a lot of color as we use that term in the East. The ceanothus would blossom and certainly they were beautiful--and she has a broom on the lower slope that blossomed beautifully. There's some poppy--but generally dark greens and low shrubs.

It was perfect for this hill with its coastal sage, Gowans and Monterey pine spotted here and there, hugging the ground or standing with their roots deep--a real permanence, a real solidarity there. She didn't violate this form at all. She tried to work with it, even as she introduced plants from outside of the Monterey County region to her garden.

Now as I look at it, the garden has changed, as it should change, as the people change who live here--my mother and father have made their imprint on it, but as I watch this transition, I am reminded even more clearly that my grandmother had a fine aesthetic quality.

She was one of these intuitive ecologists who believed in ecology and practiced 1t. There are many who today, after the decade of the sixties, believe in ecology, but because of one reason or another, they don't practice it. 
R. Rowntree: And, there are many who practice ecology who don't believe in it the way my grandmother did. The natural theologian, John Ray in the 17 th century, belleved there was an integrity in the design of the earth--the relationships that existed among things--the hydrologic cycle and the spatial distribution of plants and animals and how they all came together in the web of life.

A belief--a religious belief--in those days. We call that teleological. Whether it was designed or whether it was not designed is not the 1ssue. My grandmother believed in it-she intuitively understood it--I think she scientifically understood it also. She was totally integrated in the sense-that's why she had that power, I think, to make the contribution she did.

Lester in the Noble Tradition of the Amateur Naturalist

Levenson: I'm going to ask you a question which may not lead us anywhere! In England there's been a noble tradition of the amateur in many, many fields. The amateur naturalist, [Gilbert] White of Selden, is one whose name springs to mind. But in many fields. Do you regard your grandmother as in that great tradition of amateurs or do you regard her as a professional?

And what do you think about this dichotomy which has a certain value, but can be pushed too far?

R. Rowntree: Oh, I think it has a value as a question. I have never thought about it. I knew as she instructed us in botany and ecology that she had no formal training at a university.

She was successful because she was devoted, as an amateur, and grew into professional status because she learned--she sought information--she asked questions--she tried this and that--she extended herself into the professional realm by asking those questions--by seeking the answers--by committing her life to botanical practice.

She felt so strongly and she was so good, that she could in fact write books that were published by reputable publishers and were bought and read by reputable people who had scientific training, and I believe, who benefited from her writings, from her experience. 
R. Rowntree: In the English tradition, we have the empirical philosophy of Francis Bacon. Trying things was a way of learning about reality, learning about the world.

I always saw her as sort of a botanical modern-day Francis Bacon, working away empirically--trying this and trying that, but having a keen sense of what was right and what would work. She never lost anything. She accumulated knowledge so that she became very knowledgeable about that which interested her.

One might take this a bit further and say that we should acknowledge that she was operating in an American context. We can do those things, particularly, in a western American context.

In the period of the flowering of her professional life, in the ' $30^{\prime} \mathrm{s}$, ' $40^{\prime} \mathrm{s}$, ' $50^{\prime} \mathrm{s}$, the importance of the field naturalist, field botanist, the collector, the experimenter, was recognized.

We still, in California, know so little about the ecology of many of our own species. Take the Monterey pine, for example. Here is an endemic that is the genetic source for one of the most productive timber species in the world. Also it's one of the most esthetically pleasing trees and provides the character for many villages along the coast. Yet we know so little about the ecology of the Monterey pine.

My grandmother made a great contribution to the field ecology of California. I wonder, often, if she could have made her contribution in another professional context--in an English context or in an eastern American context during those years. We're still in the empirical stage in California plant ecology. I think she could pick up right now and go out and still make a contribution.

The distinction between "amateur" and "professional" naturalist becomes clouded as we look at the practice of natural history and ecology over the last hundred years. Some would say it lies in the difference between description and explanation. The keen amateur can describe, but it takes a professional to explain. I think Lester would have bridled at this. 
R. Rowntree: One starts as an amateur, even with university degrees. And Lester became a professional in the way I think each of us would like to. The continued pursuit, the standards, all in order to find what's going on out there in the real world. She was intimate with her world, and she had that wonderful capacity to communicate that intimacy and knowledge to those who were interested.

Levenson: That's a wonderful summing up. Thank you, Rowan. 

Lester Rowntree

RR 1, Box 210

Carmel Highlands, CA 93923

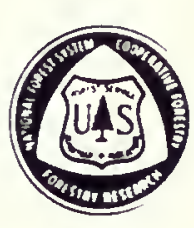

Dear Lester:

I, and many others, celebrate this day with you. Over the miles, we share intimately your lo0th birthday as a time when we can all be grateful for your contribution to life on earth. Thank you, Lester. Thank you very much.

Your dedication to ecology has inspired many to try to understand, and to try to make things better. I give you a very personal thanks for nurturing my love of plants. Your life and your mark on this world is extended through those you touched. You taught us of a continuity in life and a relationship among all things. If there is a gift that we can send you, in commemoration of this very special day, it is the same gift you gave year after year. A faith in the goodness of life; a respect of beauty in the natural world.

I add to my own love the warmest wishes of many who know and appreciate you. Happy Birthday, Lester.

Your Grandson,

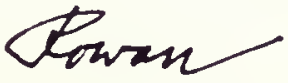
DR. ROWAN A. ROWNTREE
Project Leader
Urban Forest Research
USDA Forest Service
SUNY College of Environmental
Science and Forestry
Syracuse, New York 13210 
INTERVIEW NOTE

Lester Bradford Rowntree: Walk Softly in Nature

Professor Rowntree, the younger grandson, came up from San Jose State University on August 30, 1978, to talk about Lester Rowntree. We met in the stately conference room of The Bancroft Library. In spite of the formal setting, the interview went easily. During a coffee break under the campanile, we continued talking with fascination about Lester.

Basically, the same subjects were discussed with Rowan and Lester. It becomes interesting to see the different perceptions they have of their grandmother and her influence on them as professional naturalists and on their personal development. It was Lester who raised the question of the parental type expectations that grandmother Lester had of her grandsons. "I think perhaps that because my father did not live up to my grandmother's expectations, that this meant she then had license to lay those expectations on my brother and me" (p. 190). Both profited from early exposure to nature through the sometimes hair-raising expeditions in the wilds that Lester Rowntree conducted (pp. 191-192).

Most of the interviewees in this volume speak of Lester's religion, but perhaps it is best summed up simply in this interview. "I really consider her religion to be nature" (p. 203).

The interview was transcribed, edited, and firmly tightened by Lester. It was then final typed, proofed and indexed. Lester concluded in speaking of his grandmother. "Her works are one medium of her contributions, but living with this woman has been the major contribution. We all validate that" (p. 213). 
Levenson:

Lester B. Rowntree :

Levenson:

L.B. Rowntree:
Thank you for coming today. Professor Lester Rowntree, is that right?

Yes. I'm a professor of geography and also of environmental studies at San Jose State University.

Would you mind repeating on tape what actually happened up there at east entrance to the campus?

I drove in and presented my card, and said, "I'm Lester Rowntree. Rosemary Levenson is expecting me at The Bancroft." The gentleman said, "Well, you're Mr. Rowntree. That's funny. I was expecting a lady--a woman." I immediately thought of an anecdote that my grandmother told years ago when she first came to the Faculty Club. Evidently, Professor Jepson thought that she was a man, and many of the backgrounders were getting a kick out of the fact that Professor Jepson was quite taken aback. And here I came to U.C. Berkeley for this purpose and the gate guard greets me with, "Gee, I thought you were a woman." [Laughter] of course, he was referring to Nancy, my sister-in-law, who was here on Monday, who I guess he expected to return today. So, on that note--

Levenson: That's history repeating itself with a twist, isn't it?

L.B. Rowntree: Yes, I think it's wonderful. I think I deserve it, probably, after all of these years. [Laughter]

Levenson:

I'd like to start by asking you about your upbringing and your early relationships with your grandmother, Lester Rowntree.

L.B. Rowntree: My early relationships are ones that, I guess, have been clarified through the years, particularly as I found my 
L.B. Rowntree: professional orientation in geography. I owe quite a debt to Lester for this very early exposure and upbringing in the realm of natural history. This took such forms as, at Christmas and birthdays, giving me the books that would interest me in plant life--not just plants--she was very broadminded about this--climate, geology, and weather. So these kinds of things were what I associated with my grandmother as far as gifts went.

Implicit, of course, was that I would read these and she then laid down a certain set of expectations that I would become a scientist. In the field experiences that we shared, she was able to convey so well, as I look back, an almost mystical view of nature, which I'm sure you picked up from some of her writings and some of the other people who have been associated with her. A mystical view that has led to--or maybe was a function of her Quaker pantheism. She conveyed to us that everything in nature not only had its place but its rights, and we as humans, really were secondary to this and we must walk softly in nature. So this was the immediate emotional background behind my moving into natural history, and then specifically into geography.

Also she set a model of independence. One pursued science on one's own. She never had great respect for laboratory science, and she certainly made it quite clear that if you were going to do science, you did it in nature. She lived by that--I guess I've tried to imitate that as best I can.

Levenson: You mentioned her disapproval. Now I know that Lester was, and still is, a very feisty person, but--

L.B. Rowntree: Yes!

Levenson:

--[laughs] can you give me some examples?

L.B. Rowntree: Perhaps I'm exaggerating this, but I feel that I have spent some time, as her namesake, trying to live up to being Lester Rowntree. I experimented with going by

L. Bradford Rowntree in some professional circles at times, to avoid the confusion. So I have really thought about the carrying of her name and carrying it forward.

My field in geography has been really with cities-with urban geography. The conversations that she and I have had over the last three or four years have been basically this: "Hello Lester. How are you?" And either 
L.B. Rowntree: of us could open the conversation with that! And if she said that to me, I would say, "Fine." Her next question is, "How is your writing going? How is your research going?" I would tell her that it was going well and she would say, "Are you still concerned with cities?" I'd say, "Well, yes. I still am interested and concerned about urban life."

I could tell from the tone of her voice--she would make some snide comment that cities were not worth studying; that they were so far removed, so estranged from nature, and she couldn't quite understand why I would occupy myself that way. It was clear to me that this wasn't living up to her expectations of what Lester Rowntree should be doing.

But, if I may digress a moment, I have to say that I could never have become a great botanist because of the expectations she laid on me as a youth thinking that I would be another botanist--taking me around and pointing out the names of flowers so rigorously that, to this day, I have a horrible block.

My thirteen year old daughter is much better at remembering plant names than I.. I have to ask her, probably every thirty or forty seconds, for the name of the same flower because as soon as she tells me--bang!--it's gone. It's erased. I think this is probably a function of a blockage that comes from these very, very explicit expectations that Lester laid on me at an earlier period. So, I will not become a botanist and I will probably continue to work with cities.

These projects that I have done that have more nature in them, such as working in urban forestry, most recently, and the work that I did in the Austrian Alps--why she could understand that there were causal relationships between my examination of the forest and hydrology. That was quite all right. But the studying of cities, no--quite wrong.

Levenson: Why was it the second son who was called after Lester and not the first?

L.B. Rowntree: I really have no idea. Well, it really is an interesting question, Rosemary. I never asked my parents, and perhaps I should go back and do that tomorrow. Particularly knowing at that time, back in 1938, that my mother and Lester were probably not getting along that well--I'm not even sure that my father felt that close to her--perhaps it was an attempt at reestablishing a closeness on my father's part. I feel that at that time, he was closer to his 
L.B. Rowntree: father--of course his parents were separated. As I said, it's really a question that I never thought to ask.

Levenson:

You speak of some slight schism between your parents and Lester. Earlier, you were talking about the enormous influence on career choice that lester had. What about your parents? Normally, it's the. father or mother that places demands on the child.

\section{Heavy Expectations}

L.B. Rowntree: I think it's a classic 1llustration of when expectations are laid on the child that the child, when he or she determines they can't live up to those expectations, just explicitly says no and goes off in his or her own direction.

My father's troubled history at school illustrates that. I imagine that he had such a heavy dosage when he was at Westtown and started running away--although he seemed to come back to the West Coast when he ran away--it was in a sense saying, "No, I'm not going to be the son that you want."

I don't know at what period they achieved an understanding, but, I think perhaps that because my father did not live up to my grandmother's expectations, that this meant she then had license to lay those expectations on my brother and me.

Rowan and I have talked about this. He certainly felt it as strongly as $I$. His period of disapproval came, I guess, after graduation--his first graduation, the first B.A. He went into the business world, which people did in the late fifties. He certainly didn't plan on staying, but he was going to do that for a while. all.

That wasn't what Lester wanted from her grandsons at

What started that question? What did you ask?

Levenson: I think it was the expectations being placed on the grandsons--

L.B. Rowntree: --on the grandsons rather than the son, yes. That's right. 
L.B. Rowntree: As I was saying, Rowan and I were talking about expectations. Our parents didn't put very heavy expectations on us, and we felt very comfortable that we'd pleased them--maybe we exceeded their expectations. But we still felt that we had to live up to Lester's.

Rowan was much closer to botany than I. Through graduate school, doing forest ecology and then doing a dissertation on Bolinas Lagoon that involved a lot of good ecological thinking. So he scored high and I didn't at that time; I was out studying cities.

He maintains, of course, that he's always been jealous that she and I were the very close ones. Well, I didn't feel that was the case at all. I didn't think she played favorites at all. Maybe Rowan was just being defensive about the fact that I was her namesake.

\section{Eventful Expeditions: Practical Examples of Intuitive} Ecology

Levenson: How much do you remember of some of the trips and picnics, and so on, that you went on with her?

L.B. Rowntree: I have memorles going back to the time when I must have been three or four years old, to Bass Lake. We would go up there to spend a good portion of the summer and Lester would arrange her field season so that she could come and spend some time with us.

Those memories involve such things as having her take me out and show me niches--ecological niches--and plants and flowers, et cetera. I also remember her rather irresponsible way of playing with us in the water, to the point of my brother almost drowning--falling off an air mattress.

Thinking back, I can see my father fully clothed, plunging in the water to rescue my brother, as my grandmother blithely paddled on one of her marathon swims out into the middle of the lake, quite unaware that the children that my parents thought were in her charge, were really falling off the air mattress and drowning.

So they go back to that. I was thinking that she and I traveled fairly often, but my mother tried to correct me, 
L.B. Rowntree: saying that after Lester's first attack, my mother was not receptive to the idea of us going off alone with her. I certainly have had experiences with her in the field that-oh my God, one comes to mind all of a sudden where she and I were driving down Highway 1, south of Big Sur. She saw a plant off to the side of the road on the cliff side--it must be a good 1,500 feet straight down to the ocean. She was determined to go out and look at this plant, which meant crawling out to the edge of the cliff on her hands and knees. I know I was of driving age at this time, so she was in her eighties.

I could not bear to watch this person go out because of the precipice. I don't know what that says, except that she's remained a feisty field botanist right up to the end, and also, these were the kinds of experiences I was subject to when we went into the field.

I spoke of her incisive and largely intuitive understanding of ecological niches, and this is something that I'm very appreciative of. She knew exactly not just where plants were going to be, but also animals, insects.

Levenson: $\quad$ Can you give me an example of this?

L.B. Rowntree: There was a time on Mt. Diablo--and I believe other members of the family were along also--we had been hiking and looking at plants. I was rather curious about rattlesnakes --very curious about rattlesnakes. We had not seen one that day.

On the way down the road, she was pointing out some things and, suddenly she stopped the car--pointed and said, "We will find a rattlesnake there."

We11, now in my learned state, I know what she was looking for: a combination of nearby water, of shade, of some sun, of tall grass. But she got us out of the car and said [briskly], "Follow me. We'll find this rattlesnake." Sure enough, we found a rattlesnake. [Laughter]

But this kind of feeling--I guess I'm a great believer in intuitive science, and particularly intuitive ecology. If you just have enough experiences coming across rattlesnakes, you will certainly understand what the conditions of their niche might be and where you'll find them.

She knew this about everything: we could find bobcats, we could find owls. It was something that complemented the textbooks that she was giving me very, very well. 
Denny and the Indian Magic as a Cult Book

Levenson:

L.B. Rowntree:
When we were talking earlier about her children's books, you mentioned something that I hadn't been aware of about Denny and the Indian Magic.

Denny and the Indian Magic is one of my favorites because of its kind of pantheistic bent drawing on American mysticism and magic.

I became aware, in the middle sixties, that a group of people who we might call bohemians, or hippies, or freaks of some sort, had through a friend of Lester's, seized on this book, and It became sort of the centerpiece of a number of parties where people would get high by various means and then pass the book around, reading passages from it, and sometimes elaborating on passages as they took on characters, they became the characters, and sometimes doing new endings--and just using it, as I said, as a centerpiece for a kind of a mystical, back to nature, experience. It never became a cult book to the point of becoming another trilogy [Tolkien] or a Don Juan, or whatever. Maybe because I don't think the book is in print. But this group of people, I became aware, were using it as such. Many of them, consequently, came up to the Hill to pay homage to Lester.

I can imagine how some people, after going through Denny and the Indian Magic, might have fantasized about the author. I don't think that particular book has a picture of her on the cover, on the jacket--and like meeting Professor Jepson, maybe they thought she was a he or the author was a weirdo of some type; certainly, they wouldn't have been disappointed if they had spent the time to get to know Lester.

Lester's Writing Techniques: A Peaceful Jall in the Valley

Levenson: One of the things I noticed in the archive [of the California Academy of Sciences] was a profusion of small notes and I wanted to ask you about your recollections of Lester as a writer. 
L.B. Rowntree: [Laughs] Lester was writing constantly, and often, when we would accompany her into the field, Rowan and I would become very frustrated and restless and antsy, because it didn't seem we would get a hundred yards down the road before she would stop the car again and scribble some notes, seeing something on the side of the road. So the jaunts were just a series of stop and go, stop and go. Often, we would get to a place where she could turn us loose for a couple of hours so she could both nap, which was part of her afternoon habit, but also write and take notes.

I don't know if anyone recounted the story of her being lost in Berkeley--or missing from the house in Berkeley-one day to the point where my mother and father became quite concerned, because the car was there, yet she wasn't in her room, wasn't anywhere in the neighborhood, was not responding to calls. She must have been in her early eighties at that time--still driving her jeep station wagon around.

I don't know quite how this came out, but my mother tells it as it went on to the point where my mother and father were very, very concerned about her whereabouts. As it turned out, she had climbed the plum tree in the back yard and gone up into my treehouse, which was way, way up the tree, just to find a place where she could take a nap and write notes, put her thoughts together.

Also she, Lester herself, told the story of her constant search for a peaceful place where she could write, to put together her field notes. I'm sure you have had a similar experience where you just can't seem to find the right place where you can be isolated and left alone.

She tells of driving back from the Sierra, going through a small valley town, let's say Modesto or Manteca. There weren't any stop lights in Carmel, so she had a very bad time in cities that had stop lights because she didn't pay any attention to them.

Well, let's imagine that after she'd gone through five red lights in a row, at least as she tells the story, she became aware of a policeman motioning her to the curb and lecturing her, "Lady, you've just gone through five red lights!" She said, "Oh, I'm sorry." He said, "Well, you know, I can give you five tickets or, if I cite you for this, the fine will be twenty-five dollars." Twenty-five dollars was probably a quarter of her annual income that year. She said, "Twenty-five dollars!? My God, I can't 
L.B. Rowntree: pay that! What's the alternative?" He said, "Well, we'11 have to put you in jail." She said, "Really? Is it quiet there?" He said, "We can find a cell for you that's quiet. Why?" "Oh, do take me to jail."

So to hear her tell the story, she spent several nights in a jail in Modesto or Manteca, or wherever, in lieu of this fine, which she enjoyed wonderfully because she could put together her field notes. No one bothered her.

More recently, she has insomnia and writes most of the night, in spite of these heavy sleeping pills that she would take--they only worked for a couple of hours--and then she would lie in bed, and I'm not sure whether she would take her sleep mask off or not, but she would scribble notes --ideas about articles, books, revisions of books, letters, notes about her contacts in the other world, who she had seen--and these would all be on pieces of paper, notepads, two inches by three inches. Or you mentioned how she seemed to have gone around to every bank in California, if not the United States, and picked up spare deposit slips to scribble on.

But if you ever went into her room first thing in the morning, the room would be literally covered with these little scraps of paper with scribblings on them, each one containing a thought. I could never decipher her handwriting. Margaret Campbell is probably the only person who has been able to. And so the room would be covered; it would look like a down comforter had split during the night and the feathers were all over. Lester referred to these, very appropriately, as her night droppings. Much like a rabbit would leave droppings, or a rat scampering around the room.

I think she would actually physically lie there in bed and scribble these things, and either toss them aside or try to place them on a non-existent bed stand, and they would just float around.

As I remember her, if she wasn't in the garden, she would be on her couch, writing. Never typing. I don't know if she typed. I don't think I could tell you that. There was a typewriter in the house, but at some point, she would have to have her manuscript typed. I can't imagine any publisher going through a manuscript, or even a covering letter, in her handwriting, which was just abominable-- 
Levenson: I think in the early years, much of her typing was done by Lila Clevenger.

L.B. Rowntree: That's probably true, yes.

Levenson: What do you remember of Lila?

L.B. Rowntree: I remember Lila Clevenger more for her house than as a person, and that was because, until I don't know when it was--the fifties, Lester didn't have a driveway up to her house. Her car, then, was put in Lila Clevenger's garage. Coming home to Carmel after a field trip with her, meant carrying all of these things up that steep hill, up all those stairs, and it was quite something when she finally decided to have a driveway cut up to her house.

Lila Clevenger's house was always very dark and spooky, and that's about all I remember. I couldn't tell you the first thing about the lady, except her cats. Didn't she have a lot of cats?

Levenson: I believe so.

Ego Strength: A Driven Writer

Levenson: On our break, you mentioned something about Lester's reluctance to accept approval and applause. I mentioned something about her extraordinary ego strength, particularly as it shows up in the archive, where she sometimes had to make ten or twelve tries to place an article. I wonder if you have anything you'd like to say on the tape about that?

L.B. Rowntree: My comments about her reluctance to be honored publicly is based on experiences with her--that she would tend to not only play down but even deny any kind of public acclaim-and I think that was in concert with her upbringing. It would be an interesting psychological study, I suppose, to see if people who deny themselves the support of society at large, then become even more rigid as far as this ego strength is concerned and become even more driven. I certainly would agree that she was a driven person.

In one sense, it does not surprise me at all that she wanted to get her pieces into print. I think that maybe 
1. Lester Rowntree in dress, in desert, 1931.

\section{Lester Rowntree}

in canvas bedroll beside her collecting car, 1936.

3. Demonstrating a flower press.

4. Bear Tooth Mountain, Montana.

5. Up Piute Pass with Skimpy, the burro.

6. Lester Rowntree in desert, 1963, aged 84 .

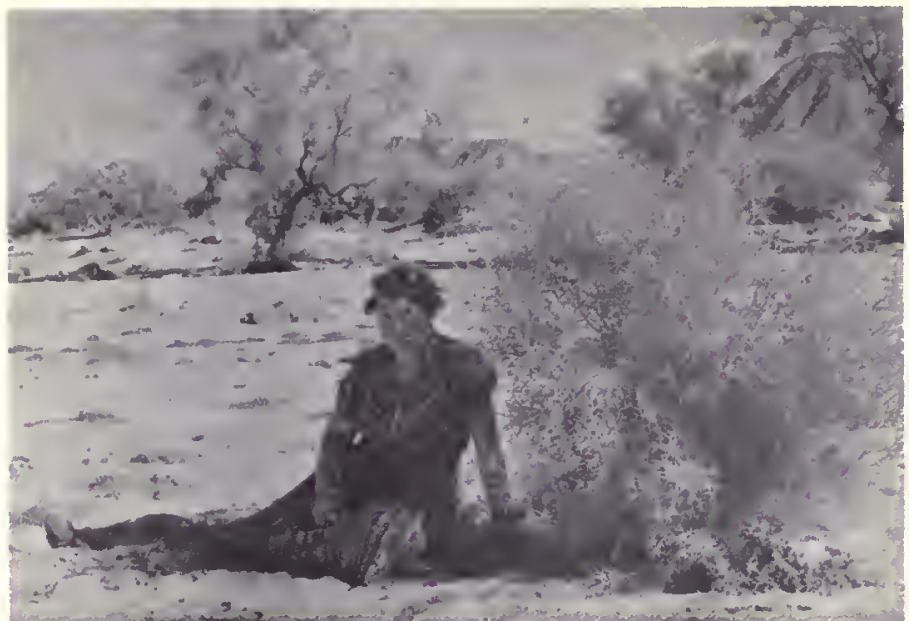

1 .

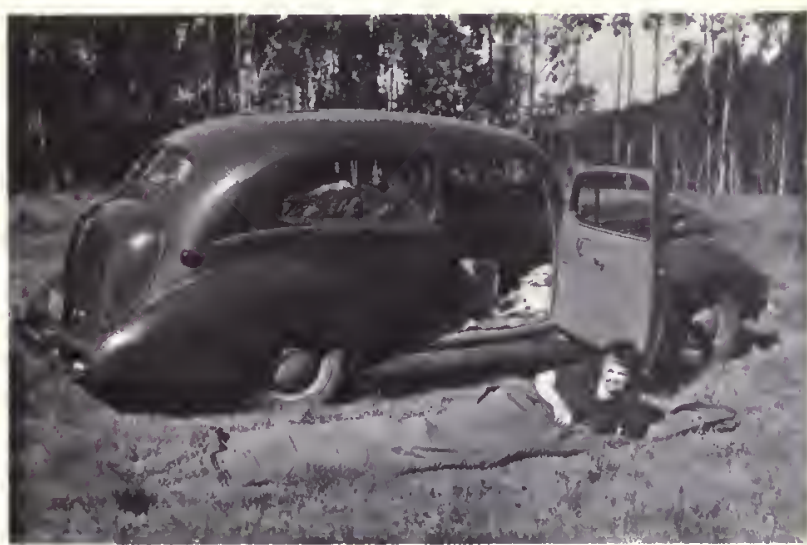

2 .

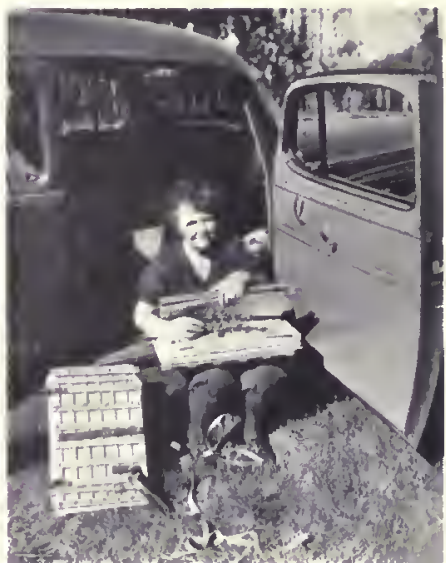

3 .

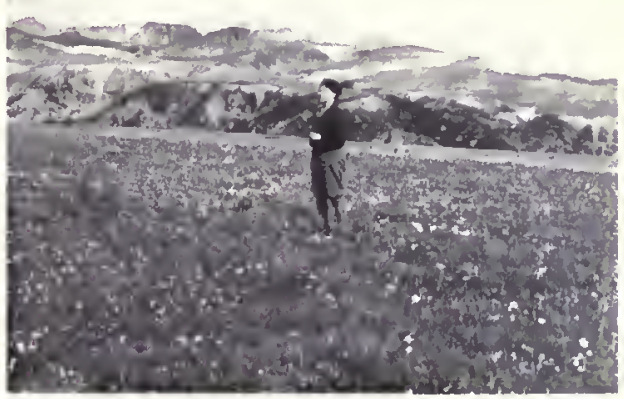

4.

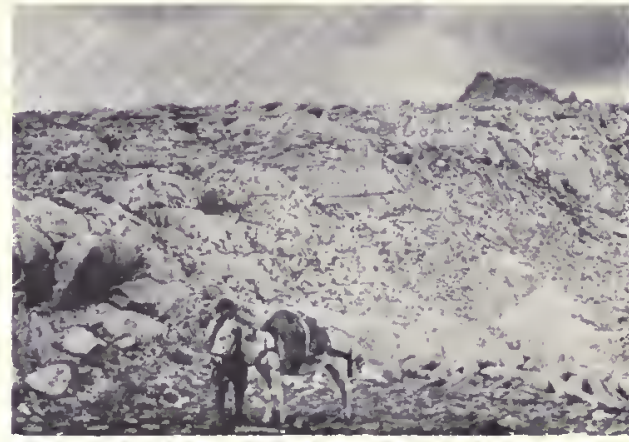

5.

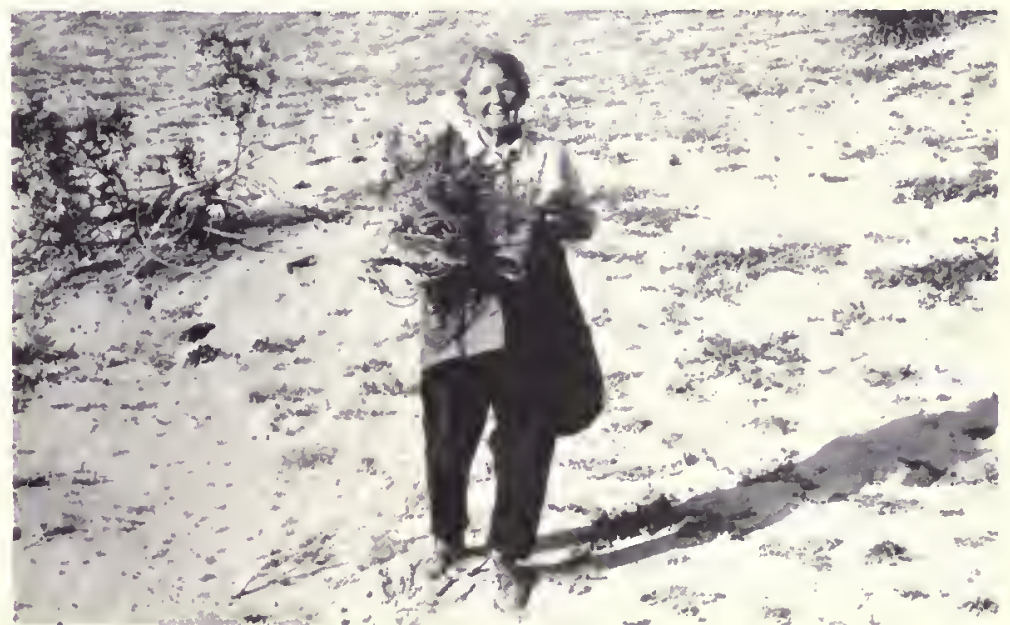

6. 
L.B. Rowntree: some of it was compensation. This insecurity, that I know bothered her, of competing with trained and schooled botanists, may have led her to be extraordinarily productive, or at least to try to get as much published as possible. No question about her ego strength. You can call it, at its seamy side, selfishness and stubborness. I happen to identify very strongly with her strong ego and believe that's what's necessary in this world to get along--to achieve what one wants.

As I was saying during the break, if I get momentary depressions from having a piece rejected, then I will have only to think of Lester's Iifetime and how many times she received rejection notices, and how it did not dissuade her at all from continuing in what she believed in and what she wanted.

Levenson: You mentioned selfishness. What did you mean by that? Got any good examples?

L.B. Rowntree: Oh, yes. Just a matter of getting her way. One thing she would not tolerate in others was selfishness. There was a period of time when I was living in her house and she was on the Mojave Desert--1t was when I had returned from Europe in 1964--and was finding myself, I think we called it then, by living in her house, taking care of it, working as a kind of hippie carpenter in Big Sur.

At the time, I entertained some notion about being a writer, and was trying to piece together my experiences in Europe, and then traveling around this country, which eventually led to my going into geography, and following conservation environmental concerns.

I also wanted to build a boat. So I went out and purchased a half-built kit from a potter in Monterey, with maybe the last one hundred dollars that Heidi and I had at the time, and brought this boat back to the house. I received a fiery letter from Lester, saying that that was intolerably selfish of me, that there was no place on her hill for a selfish person. But she thought I had selfishly denied Heidi the basic resources of life, that is, food. I thought Heidi and I had discussed the boat buying.

I was really quite upset by the magnitude of her response. I should probably try to find the letter, but I just remember that she was not going to tolerate this kind of egocentric and selfish behavior--that what I was there 
L.B. Rowntree: to do was to find out whether I was going to be a writer or not--to set about the business of writing, getting my head together, and not go off in frivolous activities such as building boats. I was very upset by the whole thing, but I just fixed on the term that she used over and over again, that I was being very selfish about this.

\section{A Wry Sense of Humor}

Levenson:

Does Lester have a sense of humor and, if so, what sort of humor is it?

L.B. Rowntree: She definitely has a sense of humor and it's a very wry sense of humor that I have always associated with the English, like Monty Python and other English shows. But up until the last three or four months, when she was eating dinner with us regularly, and we would be laughing and bantering back and forth, Lester was always a participant --always able to keep up with this--and would either add her approval by a gruff sort of chuckle, or just wouldn't comment at all. But everyone knew she was enjoying this, and indeed, she did.

I can't imagine her telling a joke, however--just sort of an appreciation of humor. I think that qualifies as a sense of humor-not an active one; just a spectator's sense of humor, you might say.

\section{Tastes in Music}

Levenson:

What sorts of music does Lester like? Were there any particular folk songs that were her favorites? I know she sang when she was a child and loved musical get-togethers around the piano and so on.

L.B. Rowntree: Yes, true. Lester loved the old English folk songs-Oberkirchen children's choir and the Vienna Boys' Choir.

Rowan and I both play the guitar and sing folk songs, and she seemed to enjoy that. She would never sing along with us. As I think more about this, I remember my mother playing the piano, say at Christmas time, and her joining in with carols, Christmas carols. 
L.B. Rowntree: She loved the Alfred Deller Quartet--high tenor, English group sort of things. She had lots of those records. Her tastes were very definitely classical music and interesting --I think earlier they were classical classical. That is, Haydn and Mozart. Later, she got into a lot of romantic classical music like Brahms, Bruckner--which would just drive me out of the house in that I am still more the classical classical person. I guess there were these waves of emotion that she could relate to.

Everyone will remember her as lying there on the couch with the music dominating the room, so that conversation was not possible. This was fine as long as it was Mozart-I enjoyed that. But when it got into Bruckner and Mahler, I found that was when I would go out and watch the sunset, the stars, or walk up the hill at night!

Levenson:

That's quite a twist with the grandmother driving the grandsons out of the house. [Laughter]

L.B. Rowntree: She was also a baroque person. I can't think of any baroque composer in particular, but certainly the Bach genre. She enjoyed his light music. Heidi, coming from Salzburg, brought her a lot of Mozart. I think she preferred the instrumental works rather than the full symphonies. Music was very much a part of her life.

When hi-fi was still in its infancy, Lester mounted two huge speakers on the wall opposite the couch. She'd lie there on the couch; she had this desk that would slide up on the couch where she could also write--but above the desk were the stereo components which, in those days, took up a lot of space, were extremely complicated--so she could both get KPFA--she never changed the FM dial--it was just "Radio Free Berkeley"--that was all. But she did learn to operate it to the point where she could also put on records.

But to see this lady--small lady--right?

Levenson: [Laughter] Right!

L.B. Rowntree: --with all of this equipment in front of her and these two huge speakers up on the wall--surely the most valuable objects in the house. It demonstrated that she wanted music around her all of the time. 
Mechanical Aptitudes?

Levenson:

Your mother says that Lester hates mechanical things, but she operated cars on terrible roads and virtually where there were no roads, and she operated a camera to produce professional level photographs, and now you tell me that she learned at least enough to get what music and news she wanted out of complicated hi-fi equipment.

L.B. Rowntree: She was intimidated by this stereo equipment to the point of not letting anyone fiddle with it. I was hard pressed to explain how I could get other FM stations than KPFA, but she made sure that I put it right back on KPFA. It may have been a function of her eye trouble at that time, that she couldn't read the dial. But that is an interesting paradox.

Lady Byng validates this in that little essay about being on a horrible road--in fact, the AAA when Lester asked about it afterwards said, "Oh, no, there's not a road there," and Lester and Lady Byng both kind of laughed.

She was intimidated not only by her hi-fi equipment, but by her beloved blender which she used to make carrot juice. Once she learned how it worked, that was it. She wasn't going to experiment in any way. She wasn't going to deviate from the instructions and she didn't want anyone doing anything else with that blender than making carrot juice.

I can't really explain it. Well, you know, I bet she probably related to the physical, mechanical world the way Uri Geller does--that she did it spiritually. She just bent spoons and made things work with her spiritual powers. That's all I can tell you! I don't think she had any nuts-and-bolts knowledge and didn't care to have any, and probably didn't need to have it. If something broke, she would intimidate it until it worked properly.

Radical Socialist and Traditional Pacifist

L.B. Rowntree: I owe a lot of my political and value clarification to Lester's traditional pacifism. 
Levenson:

L.B. Rowntree:
I'm very glad you brought that up and I would like to ask you now about Lester's politics.

Well, you know there are a whole lot of Rowntrees back in England who are socialists--that is intellectual socialists. She related and identified to that segment of the family. Then, with her contact with Bohemia here on the West Coast-and that goes back to the 1940s and '50s--the people that she had social acquaintance with, both in Carmel and people in the Bay Area, were really those people who she respected. So that whole very liberal kind of political posture was very comfortable to her.

Her politics were not manifest in day-to-day activity: they were manifest rather by supporting KPFA [Berkeley FM radio station] during the [Joseph] McCarthy days, and supporting a number of leftist magazines, and sending people money--I.F. Stone was another great favorite of hers.

And these people who were black-listed, purged, harassed in all sorts of ways--in the late forties, they were people whom she identified with, and to whom she financially contributed. If you can imagine a person living on two hundred dollars a year sending money to these publications and these people, I think that's really an excellent expression of her political beliefs.

She also, as a Quaker, was certainly very pacifistic. This is what I picked up from her. I actually entered the army and then had my values clarified from that experience and became a conscientious objector while in the army, and finally was discharged as a conscientious objector. That happened to coincide with the beginning of Vietnam and I became active in the anti [Vietnam] war movement.

But I think Lester had a very well-defined political position. Again, to summarize, I characterize it as rather far to the left, but in a very abstract and intellectual sense. She would be the last person in the world, of course, to take part in any kind of a communist or a socialist down-to-earth, organization activity. But she, just out of her beliefs that humans are essentially good and should share, had great empathy for minority and oppressed peoples of every kind--was picking them up on the highway, giving them shelter, and again, sending what limited funds she could to them. So I look upon her as being a model, not just intellectually, but politically also. 
Levenson:

L.B. Rowntree: I had always assumed that she had. What makes you believe that she hadn't?

Levenson:

L.B. Rowntree:

Levenson:

L.B. Rowntree:

I don't believe one way or the other, except that I have no evidence that she did. she ever discuss her vote with you? it was less a belief in the democratic experiment here in did take her into these countries.

Did she ever discuss voting with you--did she vote for Democratic candidates or not?

I don't think she ever discussed voting.
Do you happen to know if she ever became an American citizen?

The second question, that follows on from that, is did

Well, if she became an American citizen, I can tell you that the New World and more a practical concern of getting in and out of Mexico and Canada on a regular basis. Her field work

She and I would have this argument, during the sixties, when she was still very sensitive to the political climate of the war and the resistance. Of course, I was very concerned with people not taking this abstract, intellectual, spiritual, mystical view of politics that she preferred to work with--she was going to change people through the spirit, you see, and that's great. I think she probably has changed more people than I have through door-to-door, face-to-face confrontations.

But the argument would go that I thought every vote counted and therefore she should vote for Gene McCarthy in '68, and she should do this and that. She would nod as though she accepted my argument. Whether she ever got down to the polls, Rosemary, is another question that I can't answer. I would like to believe that she did.

I know that in 1948, when Henry Wallace was running on the socialist ticket--I somehow remember that she was a fairly strong supporter. Again though, whether she got down and actually voted for these people, I don't know. 


\section{A Pantheistic Quaker: What Felt Right, She Did}

Levenson:

We've been skirting around, but not directly talking about, her religion. I think at the beginning of this interview, you defined her as a pantheistic Quaker.

L.B. Rowntree: Yes.

Levenson:

Do you want to say a little more about that?

L.B. Rowntree: Okay. She, of course, had a very formal upbringing in Quakerism. It would be really interesting to pin down the last time she attended Meeting. I do believe it was as late as the late forties or early fifties.

She sald there were two kinds of Meetings: good ones and bad ones, and the bad ones could be a function of a few talkers, as she called them. The structure of the Meeting is a period of time when people can either sit in quiet and meditate or are walting for a message to share with others, so some people can monopolize that time to the point of becoming quite boorish.

At the risk of offending some people, I know that she considered the Monterey Meeting to be a bad Meeting. She did not attend that. She had a lot of social contacts with people, but did not go to that Meeting. There was a Meeting in Berkeley that she liked.

Her formal participation in meeting Quakers has been limited in the last thirty years. She was very active in the AFSC [American Friends Service Commlttee] to the point of sending them money; really participating in all sorts of different ways. She liked to separate the Friends Service from the Quaker religion.

I really consider her religion to be nature.

When I look back at what Thoreau and Emerson did with American transcendentalism, I don't think her belief was that formal--she just believed God was to be found in everything in nature, in inanimate as well as animate objects. Rocks were of equal status as plants in her mind, humans were certainly part of nature, but somewhere, we had gone wrong and we were capable, of course, of being very destructive. Consequently, we had to atone for these sins by revitalizing our reverence and respect for everything natural. 
L.B. Rowntree: She was never concerned with labels. I'm sure you've heard that one before! That was the last of her concerns, beginning with botany and ending with politics or religion. It wasn't what it was called; it was how it looked and felt, and what felt right, she did.

Contacts with the Bohemian Community: Lester Valued as a Genuine Eccentric

Levenson: You mentioned her Bohemian connections.

L.B. Rowntree: Yes.

Levenson: Again you're the first person to bring this out, and I'm delighted. I'd like you to go on about that a little.

L.B. Rowntree: This was delightful to me, also. She seemed to have contact with, say the Carmel Bohemian community. She was certainly a respected member of that community because she was such a genuine eccentric.

During the late fifties--at that time, they were called Beatniks--she was very emphatic with any kind of a statement against-well, it sounds trite, but, you know, the materialistic culture of the late fifties--self-satisfied culture.

When she had house visitors who were not botanists, they were people of that ilk who had come to her for spiritual guidance. They were all people I felt very comfortable with and they, until just very recently, would come back to pay homage of one sort or another--and they're Beatniks, Bohemians, hippies, weirdos, of all sorts.

She would generally choose amongst the hitchhikers who were on Highway 1 and would almost always pick up the longest-haired, most-bearded male. But it was kind of contradictory because she had such expectations about personal cleanliness and manners--her Victorian upbringing! It probably created a good deal of tension for the poor lady. She enjoyed these people intellectually and their spirits, but probably on a moment-to-moment basis, could take them only in small dosages.

I believe she had a personal relationship with Henry Miller and the other Big Sur people. I mentioned the relationship with Alan Watts, that $I$ have no idea how this 
L.B. Rowntree: evolved. Well, she supported a number of Zen activities-I think was an original supporter of Tassajara when it became the Zen monastery.

Tea and Conversation

I.B. Rowntree: She constantly mentioned how in her household back in England, her father was always bringing interesting people by. That was the important thing, that they were interesting. There must have been very spirited conversation amongst the adults.

She always mentions how the children, of course, were not allowed to speak unless spoken to, as you might expect in a good Quaker, Victorian household.

Levenson: How did Lester entertain you and your friends? Was she much of a cook?

L.B. Rowntree: [Laughs] I will offend 80 million English when I say that I've not known an English person who could cook! Yes, she liked to kill potatoes through boiling and meat the same.

Entertaining took place at teatime. It would have to be rather an important and interesting person who she would leave her garden for to have tea. This was not a high tea in the sense of sitting around cookies and polite conversation; it was a matter of crawling in from the garden from three to four in the afternoon, which was a much-needed break for those of us who were working with her; throwing the tea into the pan and the water, and boiling it. She would always bring out some biscuits, as she still refers to them--and this was the time for talk.

Dinner was always a problem for her. The answer to your question--no. I don't think she cooked. She felt burdened by any visitors who were not satisfied with raw comfrey--things out of the gardens--nuts, cheeses of any sort.

If my brother and I were coming down to visit, she would either go out and buy a roast beef and cook it, and that was ours then to do with what we wished over the next few days. Or she would just very simply say, "Well, bring 
L.B. Rowntree: what you want to eat because I'11 be eating my nuts and vegetables." I think she was mainly a vegetarian, both out of spiritual comitment and also out of economic necessity--out of the habit of living in the field.

As far as entertaining went, she sort of enjoyed evening conversation. If some people came by with a bottle of wine, she would certainly participate, and thoroughly enjoyed that kind of thing up through the late 1960s. Of course, by that time, she would have been ninety.

A very spirited conversationalist. Well informed at one level, that is at kind of the level of dealing with the spiritual activities of people. If you wanted to talk politics, she wasn't so well informed. Although, it sort of depended on KPFA's programming schedule. If her dinner coincided with the evening news, then she was extremely well informed. That usually took place in the winter when darkness would have come by six, and she could no longer work in the garden. During the summer, she wasn't well informed.

She never read a newspaper. I don't think I ever saw a newspaper in her house that she had looked at. She bought them now and then to start a fire with--that was about it.

Levenson: That's a wonderful approach! And she needed them, of course, for pressing her specimens.

L.B. Rowntree: Exactly, yes. But I don't think she ever read them.

Hard Labor at the House on the Hill

Levenson:

You mentioned working on the Hill, in the garden. If you would, I'd like you to talk about how you feel about your grandmother's house on the Hill and how you reacted to, what I gather was sometimes the quite dictatorial methods she used to get people to work in her garden.

L.B. Rowntree: There was a contradiction because she, of course, looked upon the Hill as the seat as well as the source of spiritual power. The Hill was to be revered and it was a place of spiritual revitalization when one needed it. And it was open to all members of the family as well as the broader community. 
L.B. Rowntree: However, if you came to the Hill, you were expected to work in the garden. The contradiction was that I didn't personally find working in the garden to be harmonious with my desire for spiritual regeneration. Now, that was my failing, I guess. It was damned hard work! of course, we're talking about a time when she was in her eighties.

She saved all of the hard labor, either for hiring a person to come up from Carmel, or for one of her grandsons, or maybe for her son, to do. That meant that when we came down for spiritual regeneration, she had a list five or six pages long, of heavy labor that had to be done.

I guess she thought that if we rose at sunrise, as did she in those days, and worked until sunset, there was time for everything. Being a person of the flesh, I also enjoyed going to the beach, to Carmel, and doing other things than meditating on the Hill and gardening.

But there wasn't much we could do about that. It was dictatorial--I like your word. It was hard work. It was exhausting. How she, as a woman of eighty, kept up and worked in that garden, I'll never know. Just a paragon of physical endurance. I've always thought of myself as being in fairly good shape. I'm certainly not a decadent urbanite, as she thought many people were, but I could hardly keep up with her in her gardening.

It's not quite fair to say she saved all the hard labor for us. She would be out there with wheelbarrows, moving rocks, and other things. But she thought as long as there were these husky youths around, that her efforts could best be spent in planting, and we would do the laboring.

So my memories are not always fond ones. I imagine that my poor father has very similar kinds of memories, although I don't think I've ever heard him complain about his youth. But I can imagine it; he probably was out in the garden every day, for a good twelve hours of work.

Lester's Spiritual Energy: The Bond with the Granddaughtersin-Law

Levenson:

You mentioned Heidi. Can you tell me how Lester accepted her? I know that Heidi had her first baby in Carmel. 
L.B. Rowntree: Well, it is my daughter also. We had our child in her bedroom in Carmel, which if you're interested, involves a rather funny story. Heidi is an Austrian. I think when I wrote to Lester from Europe and said that I was marrying an Austrian, she wrote back and said, "Oh, I'm so glad you're not marrying an American."

Lester remained, at one level, rather anti-American throughout. She was not just a believer in Britain but also a believer in European civilization. So Heidi had a lot of things going for her before she ever arrived in this country.

Then, when we did get back to California, Lester and Heidi hit it off immediately because of a great concern with the spiritual activities of this world, this universe. Heidi is a very mystical and spiritual person. I guess Nancy [Rowan's wife] is too. Nancy and Heidi have related to Lester in much the same way.

I think Rowan and I preferred not to get into that too deeply; that we preferred to keep it in the professional, intellectual realm. It's interesting that it's Nancy and Heidi who really saw the spiritual energy there. That's what they identified with and that is a relationship that continues today even though Heidi and I have not been married for years.

Heidi enjoys the Hill--she enjoys my parents, she enjoys going down to see Lester, and continues to talk with her about other worlds. That, I would say, is the basis of their relationship--that Lester always respected Heidi tremendously and vice versa. I sometimes was a little envious, particularly when things weren't going well between Heidi and me, that Lester's allegiance seemed often to be with Heidi.

\section{A Great-Granddaughter Born in Lester's Bed}

L.B. Rowntree: The story of our having Erika, our daughter, in her bedroom --did anyone tell that story to you? Well, Heidi as a European, and because of her family upbringing, did not believe in doctors. She believes in homeopathic medicine basically--more so then than now. 
L.B. Rowntree: She became pregnant and she knew she was pregnant--didn't need a doctor to tell her that. She knew that she was healthy and knew that everything was proceeding well. She and $I$ were living in Lester's house in the Highlands at this time. Lester was south in the desert, as she was each year.

Heidi, then, wanted to have the baby at home, on the Hill. This was in 1964--Erika was born in '65--a little early for home deliveries around here. We connected with Lester Haze1, who lived down the street in the Highlands, and who had been very interested in natural childbirth and knew a bit about the midwifery activities going on. There weren't many at that time.

She also knew of a doctor in Monterey who would make home deliveries--the only one. It was Dr. Fry. The trouble was that Dr. Fry was also an ornithologist and was off in Samoa and Tahiti with the Stanford marine research biology ship and was not expected back until early September.

Well, our child was due in the middle of September. Heidi said that was okay; that was just fine. Lester Hazel said, "Oh, I know Dr. Fry will be happy to come out to the house and deliver the baby. There's just absolutely no problem. You should, of course, see him as soon as he gets back."

So Heidi didn't go to a doctor for eight and a half months. Dr. Fry gets back from Tahiti. Heidi makes an appointment and walks in, obviously pregnant and said something to the effect of, "Dr. Fry, I believe I am pregnant." Dr. Fry said, "Wel1, just offhand, I believe you're pregnant too. If you're not, you might have a real problem with a tumor" or some wry comment like that.

Heidi and he talked then, and he assured her that she was right. We made arrangements that the baby was going to be born up on the Hill. At that time, I had returned to school, and Heidi and I were living in San Jose. The baby was to be born in Carmel. My mother drove Heidi down for a checkup on the 22nd. of September. Dr. Fry said, "It should be about a week." Drove back to San Jose, entered the driveway of our house, and Heidi had her first contraction there.

Well, we were primed for home delivery. Dr. Fry was going to do the delivery, but we were primed for not going to a hospital and doing everything up to that point. Lester Hazel was very happy to instruct us in this. I called Dr. Fry around eleven o'clock that night and said, "All right, 
L.B. Rowntree: the contractions are so many seconds apart"--or minutes-I can't remember the details. But Dr. Fry had seen Heidi that afternoon; so assumed we were in Carmel. We were in San Jose, an hour and a half away. He said, "Go back to bed and call me at six in the morning." [Laughs]

So Heidi went back to bed. It was midnight--the contractions are getting closer and closer. Finally it dawned on us that Dr. Fry thinks that we're in Carmel and that we're already in the bed where the baby is to be born. of course, he's not going to come out until the very last moment.

The arrangement was that we would ring up Lester, who would then get out of her bedroom, and Heidi would have the baby in her bedroom, after putting on rubber sheets and boiling water. Lester always has had trouble sleeping and always has taken a large number of sleeping pills--probably beyond what most people take for suicide--she used to take them every night. So she slept rather soundly once the pills started working.

Heidi and I drove to Carmel at two o'clock in the morning. I had asked my mother to call the house, wake Lester up, and have her prepare things. Of course, Lester didn't hear the phone ringing at all. Heidi and I rush in the house, the contractions coming rapidly, expecting to find lights on and everything going according to plan. The lights are all out, and Lester is sound asleep in this bed. Not only is she sound asleep, but because she was essentially drugged as she was every night, I could not wake her.

Heldi, who was getting a little anxious about this time, started looking around for alternative accommodations, like under a pine tree, or the couch, or whatever! We finally got Lester up and got the sheets changed. It turned out that Erika wasn't born until about eleven o'clock the next morning. But with your firstborn, you never know, I guess.

The Great-Grandchildren and Lester: Happy Feelings

L.B. Rowntree: Lester was very happy to have this child born there.

Erika, our daughter, still relates to that house and has reaffirmed it as a seat of spiritual and mystical power. 
L.B. Rowntree: Believe it or not, when Heidi and I were driving up that road, just before Erika was born, it was like a scene out of Bambi, there were so many animals running along next to the car--wild life of all kinds--raccoons and deer and foxes, were all running up to the house with us. I know it sounds crazy but it was true.

Levenson: Isn't it remarkable?

L.B. Rowntree: Yes, it is remarkable. So, I think that hill is a very special place. I was very glad that Lester allowed us to have our child there.

Levenson:

What sort of influence has Lester had on Erika, your daughter?

L.B. Rowntree: It would be interesting to try to pin that down. Erika was born in 1965, so Lester would have been in her late eighties at the time. She was the second granddaughter--no, greatgranddaughter. Lester's been so much a part of our lives that I keep skipping a generation; she is really Erika's great-grandmother.

I know that Lester was, and is to this day, very fond of all her great-grandchildren, who now number eight. But I sense she's particularly fond of Erika because she was born in her house. She has always, I guess, enjoyed Erika's manner and style--Erika has a great empathy for natural history which could come from her father and mother, as well as her great-grandmother. I don't think there have been any set of expectations or any negative emotional waves or implications at all. There's been nothing but pleasant rapport between Erika and Lester.

Levenson: Did she read any of the children's books that Lester wrote?

L.B. Rowntree: Erika has, yes. She was sort of blasé about that. I can probably understand it. You look around the house and there are books by all sorts of relatives. I think poor Erika has a rather biased view of the world--being born in this beautiful place in Carme1, growing up in that area, then because of Heidi's upbringing in Salzburg, spending summers in Salzburg --she thinks the world's a very beautiful place--that there's no ill, no poverty, no this or that. That relatives write books and are all very creative, learned, so I can't say whether she was impressed with it. 
Lester's Contributions to Horticulture

Levenson: We've touched, tangentially, on Lester's influences and on her achievements. How would you sum up what you think of her contributions in the various fields we've been discussing and perhaps the ones we haven't been discussing, such as native plants?

L.B. Rowntree: I think she has made an immense contribution to California horticulture. I see that mainly through the respect given to her. There seemed to have been no question when the [California] Native Plant Society was born that she would be the honorary president. They immediately went to Lester, which I think was symbolic of the stature that she enjoys.

As a geographer, I must say that reading her books, Hardy Californians, Flowering Shrubs [of California]--I not only see my grandmother, but I can remove myself from that and see a person who knows nature.

She was always ambivalent about not being formally trained as a botanist. Sometimes she would make snide comments about people who did botany in the laboratories as opposed to those who did it in the field. It could have been generated by some envy. But she belleved you did science in the field. As I said earlier, you did it in nature.

\section{A Role Model for Independent People}

L.B. Rowntree: She has served as a role model for a number of women of all ages, who are interested in gaining control of their lives, whether this means divorcing one's husband and striking out, as Lester did, on a professional career, or just standing up for one's self and saying, "Look, I want to do this and be independent." Lester has always been extremely supportive of that independent role.

To various degrees, you know, women have come to her knowing that she did this back in the thirties; she has always remained a champion of women's Iiberation, if I may use that term. So her contribution to these people, I think, has been immense. 
L.B. Rowntree: You can see it within our own family--she's always championed Heidi's and Nancy's right to be their own persons. In the family, it was just assumed that this would be the case. But both Heidi and Nancy took a lot of strength from the fact that Lester repected this.

She has also given my sister, Pat, a lot of strength, too, as a role model. I would say there's been that contribution.

She has contributed to people outside of the family-males, as well as females, who have looked upon her as some kind of a role model--just a being. You could almost call it an alternative life style--she did it back in the twenties, she made it work--we don't know how, really, but she did make it work.

She has given a good deal of strength to a large number of people. I mentioned before the people coming by constantly and calling to pay homage to Lester--making treks to the Hill to see her one more time. They've been doing this for the last twenty years, expecting that to be the last time that they would see her.

I think there are probably hundreds, if not a thousand people, who have taken some spiritual strength from her in terms of a role model.

Then there is the unknowable. And that is her contributions in the spiritual sense, which probably Nancy and Heidi speak of that I don't know about, but certainly it's been there. She's done some very, very admirable things at that level. So, those are the contributions, within the family. She's been a great source of energy. I always thought of her as my spiritual advisor--my intellectual role model. I know my brother feels the same way.

Her works are one medium of her contributions, but living with this woman has been the major contribution. We all validate that. 
Patricia Rowntree Nash: "Memories of Nanniesther"

Lester Rowntree's granddaughter, Patricia Rowntree Nash, lives in Oregon with her husband and four small children. On my October visit to the Rowntrees, she telephoned, and I had an opportunity to talk to her. She felt that the following letter, written on the urging of friends, fairly summed up what she recalled of her grandmother. Since she was born after her parents moved to Berkeley from Carmel, she did not see as much of Lester as did her brothers. I thank Pat for her permission to use the letter in this volume of tribute to Lester Rowntree. 
[Letter from Patricia Rowntree Nash to Midge Lyman and Ginger Peterson, April 18, 1978.]

Dear Ginger and Midge,

First of all, when I think of Nanniesther, I remember from my earliest days someone who was always brown as a nut; eyes that flashed like a little bird's, smelling so clean like outdoors, with skin that no matter how weathered, was like the feel of silk. I must have been four or five when I first remember camping with her.

I remember she used to tell us so many stories: ones that were her experiences with nature, strange things that she had done with the Indians, or in Mexico, animal stories of foxes creeping up to her campfire in the desert and she'd keep her mind blank so that they wouldn't think she would want to pet them or harm them, and stories that she made up--one I remember especially in which I touched a magic place on Rowan (or was it Lester) and he flew away. This stemmed from a game we used to play when $I$ was very little where I would touch an ear and Rowan would make a funny face, and I touched an elbow and he'd make another funny face, and I'd touch his nose and he'd squeak. One day I touched the wrong place and he flew away and had all sorts of adventures before we could get him back.

I remember walking with Nanniesther in Tilden Park, where I learned first about plants and what the Indians used different plants for. She would take me around the Botanical Gardens and give me a very nice tour, geared to the interests of a child. I remember with sorrow the day when I was told that she was too old to walk with me in the hills above Berkeley anymore.

I also remember Christmases at Berkeley when she'd send us holly and she'd bring pinon incense from the desert and bring us these wonderful little candies that my mother never liked that were like sugar on the outside that crunched in your mouth with some liquid inside. I really don't know what they were but I never think of Christmas without thinking of them. I vividly remember one Christmas when she brought me a gift and I opened it; I remember we were in the hallway of the house on Eldorado. I was so entranced and overjoyed with it that $I$ went racing off to find someone to show it to. 
I was at an awkward age anyway, but I forgot to say thank you right away and when she found me and asked if I wasn't going to say thank you to her, I burst out crying at the thought that I had hurt her feelings because I thought that if someone hurt this delicate grandmother's feelings, she might just wither away. Little did I know she was not so delicate to be able to go through all she had gone through, but I sure remember that incident with shame and I always try to say thank you right away.

I remember collecting seaweed with her at the beach for the compost pile and digging potatoes in the vegetable garden and the clean smell of the earth (she sald never to call her soll dirt) on the carrots from her garden. I remember walking up Mal Paso Creek with her, looking for watercress, and going to Point Lobos. When her eyesight got worse I remember my sense of fallure at not being able to describe birds to her so she could tell me what they were.

When I think of the hill I think of "The Hill", with the scent of freesias, and Love-in-the-Mist, and rosemary, the sound of bees humming, and the feel of the sun on the back steps or on the deck. I remember the smell of the driveway just after the first rain had such an excitement to $1 t$.

Mostly it seems I just remember flashes of things. I don't know if It's golng to be much help to you. I remember her telling me of when her sister died of typhoid in Kansas, and when they moved to Altadena. All the children had chewing gum and the Lester family thought that the children in Altadena never finished thetr dinner before they went outside.

I wasn't aware of her eminence until I was older, so I don't remember that so much, but I know she corresponded with several interesting people, Roger Tory Peterson, Henry Miller among them.

Well, that's about all I can think of now. I hope your article turns out well. It sounds like an exciting class. Ginger, your weaving sounds inspiring. I just made a visit to a weaving store in Bandon and got inspired, but nothing is happening yet. We just put a new bedroom on the house and things are moving along on the house fast, and there's always something to do on $1 t$.

It's $7 \mathrm{a} \cdot \mathrm{m}$. now and I've got to get the kids off to school, so thanks for the letter and I sure hope to see you this summer.

Love, 
INTERVIEW NOTE

Nancy Rowntree, with Jennifer Rowntree: $\frac{\text { "Keep Your Pores Open and Keep }}{\underline{\text { Listening }}}$

Nancy Rowntree, who lives in Syracuse, New York, drove down from Sacramento where her parents live, with her oldest daughter, Jennifer, for a meeting in the conference room of The Bancroft Library on August 28, 1978. The traffic had been difficult and so was the occasion since all of us knew that this was probably the last time that Nancy and her three daughters would see lester. Nancy was at another turning point in her life since she and Rowan had just separated. Lester was in sharper focus than ever for Nancy who was able beautifully to express some of the love that Lester had inspired in her. "I remember being totally fascinated by this woman. . . I don't think I had ever met anyone who listened to me the way Lester did. She always stretched me. . I guess she's especially important to me because she was the first woman I was ever really close to. It's different than a mother relationship. . . It's just been a very special relationship" (p. 220 and p. 226). And later, talking about Lester's garden and how plants flourished there, Nancy says, "I think a lot of people bloomed there" (p. 252).

We took a break under the campanile and went on talking about Lester. Nancy found the interview hard and showed real courage in reaching down into her feelings to show readers her special images of lester. She says Lester rarely criticized anyone. (This is not the way Rowan and Lester felt.) Lester as a role model is a strong presence, not primarily as naturalist and writer, but as a woman who took her own life into her hands when she was over fifty and made a lot of it. "I went through a period when I felt time was running out. I had to make changes and do it now, and I think of Lester. There's no hurry. But she's always an inspiration" (p. 235).

When the interview was over, Nancy felt there was much that she was going to want to change or add to on reading the transcript. As it turned out, her changes were mostly stylistic, and the spontaneously honest and emotional quality of our interview is retained. After Nancy's approval, the revised transcript was final typed, proofed, and indexed. 


\author{
"KEEP YOUR PORES OPEN AND KEEP LISTENING" \\ Nancy Rowntree, with Jennifer Rowntree
}

Nancy Meets Rowan Rowntree at the Beginning of Freshman Year, 1956

Levenson: Thank you so much, Nancy, for making this trip to Berkeley from Sacramento to talk about Lester Rowntree. I'd like to start by asking you where you were born and brought up?

Nancy

Rowntree: I was born in Oakland in 1939. We were forced to move from there in 1941 as the freeway through Montclair took our property. We moved to Orinda. I think the [Caldecott] Tunnel was fairly new, and it was country out there.

The village had a stable, the drug store and post office, and a garage. It was really a beautiful place to live. I lived there until I moved to Berkeley in 1956.

Levenson: When did you meet Rowan?

N. Rowntree: I met Rowan the third week I was in Berkeley. [Laughter] I lived in the Alpha Phi house on Bancroft Steps and met him there.

Levenson: Was he an undergraduate too?

N. Rowntree: Yes.

Levenson: What did you major in?

N. Rowntree: In those days, they had general curriculum, and I stayed in that until they threw it out. It was such an overwhelming experience to come from Orinda to [the University of California] Berkeley. For me, the world opened up. I didn't want to major in anything. I just wanted to take a little of everything. Finally, I did major in social welfare because it had all the courses I wanted to take. Any sort of career seemed a long way off. 
Levenson: What was Rowan majoring in?

N. Rowntree: At that point, I think he was majoring in business administration.

Lester Rowntree: "She Would Listen"

Levenson: When did you meet Lester Rowntree, Rowan's grandmother?

N. Rowntree: I first went to her house that spring after I met Rowan. She was away. She had taken her jeep and she was off to the desert. Must have been winter. She was off in the desert, and we had gone to Carmel to stay with some friends. We had to check on something or drop something off. We used to make those kinds of trips to her house and never meet her.

Rowan seemed very reluctant to have me meet her. I got very curious.

Levenson: Why do you think he was reluctant?

N. Rowntree: I don't know. Maybe he thought I would think she was odd, maybe I wouldn't like her. I don't know. But I finally did meet her and I don't remember exactly when I first met her.

That's something I have never thought of. It's just as if I came to know her. I think we went in and we had tea. The house is very different now. It was really a cottage before. She would sit on her--well, you couldn't call it a bed--it was a narrow bench with a cushion on it, and she had a board behind her, and this marvelous table that pushed back and forth. She had all her writing stuff on 1 . She could sit with her feet up.

I always sat on the hearth. I remember being totally fascinated by this woman. It was an easy relationship. It was easy to get to know her. It was easy to be comfortable with her.

Levenson: Can you put your finger on what was so fascinating about her then?

N. Rowntree: I don't think I had ever met anyone who listened to me the way Lester did. She would listen. She always stretched me. Wherever I was, lester always pulled me on, or pushed me on. She always would drop something--a little phrase that you would 
N. Rowntree: think about for three days, would wonder what she meant and how many meanings there were to that. I have not yet met anyone like Lester.

Levenson: I'm fascinated by this because so much of what's been said about her was that she had to be alone. She had little time for people. One gets a very contradictory image; yet, at the same time, she obviously had enormous influence on certain individuals in person, not just through her writings. Can you give me a "for instance" of this pulling or stretching that you talk about?

N. Rowntree: Just a side thing, I had never read much of her writings. I have read a little bit--somehow that's in the future--so it was from the person that I mostly know her.

Lester loved to sing as a girl. She talked about a secret she found to reaching high notes. You didn't strain to get to the high notes because it didn't ever come out right. You just approach them from above and drop down on them. Somehow, it was sort of an easy way of stretching.

Levenson: That's a lovely example.

N. Rowntree: I like to be alone a lot. I always felt I could live the way Lester did. Maybe in a lot of ways, I could identify with her needs. I felt I could have that kind of lifestyle very nicely.

Lester as Something of a Guru Figure

N. Rowntree: When she was with people, there were intense relationships I think. When she was tired, she would go off to work in her garden, or go to bed. Or there would just be lots of moments sitting out in the terrace, being together and not speaking, and that was comfortable.

She did have tremendous influence. I think that maybe nobody will ever know how many people she influenced. I think maybe nobody will ever know how many people came by that house. People would drop in. They would hear about Lester. They would come and they would say, "We11, I heard about you from a friend, and I was hitchhiking up Highway 1 , and I just wanted to meet you." She became for a lot of people, sort of a guru.

Levenson: How did she receive these admirers? 
N. Rowntree: She was particular. If they were phoney--if she thought they were phoney, she would give them her time, but she wouldn't really encourage them to come back. She was pretty generous with her time.

Levenson: What sort of influence did she have on her grandchildren, particularly Rowan?

N. Rowntree: I don't know what happened before I came along. I felt there were years where they didn't see her much. There was sort of a sadness about that. I think there was some feeling that as children, if they went off with Lester, she might have a heart attack and drive the jeep off the edge into the ocean, or something, and the children shouldn't be with her. Well, today, that's kind of funny to look back at!

She's still very much alive.

I think the quality of relationships always change when another person is added.

Lester and Ecology: "It Was Still a Word People Had to Look $\mathrm{Up}^{\prime \prime}$

N. Rowntree: I remember in 1956, ' 57 she would talk about ecology. And it was still a word people had to look up. She said something like: "This is where it all is for me. It's all in this word. We are all one." She was very much aware of what we were doing to the earth and to ourselves. Lester knew what was coming. She was an inspiration to us to do what we could about it.

I think without her inspiration, Rowan would never have gone back to graduate school.

We became active in the old conservation movement--in the Desert Protective League, I guess it was. We lived in Los Angeles for a short time, and we used to go out in the desert and visit her.

Levenson: At Twentynine Palms.

N. Rowntree: Yes. She used to go there and visit Josephine Jackson. We would go out there. She introduced us to the high desert. You drive through in a car and you think, "What a godforsaken place." You get out and you walk up a wash with Lester for three hours and you're in love with the place. She made things 
N. Rowntree: live. She just pointed everything out. We became very fond of the desert.

I guess we got somewhat involved in the Sierra $\mathrm{Club}$ and a lot of other activities.

Lester supported a lot of causes that she felt were worthwhile, and she was active in a lot of things.

Lester's Extraordinary Perceptions

Levenson: What about when the great-grandchildren came along? Jennifer--

N. Rowntree: Jennifer was born in Pasadena. Oh, I've got a good story!

Jennifer was born in Pasadena. One day I went out and did all the washing at the laundromat, cleaned the apartment--one of those days when you do everything--and went to bed about 4:30 and took a nap and woke up in labor--and went to the hospital.

Rowan got caught in a traffic jam, but he got home finally and took me to the hospital. And Jennifer was born.

When he got home from the hospital, he went to the mail box. (I had neglected to get the mail.) He opened a letter from Lester, which I'm sure I have, and it said, "Tonight will bring a new moon, a baby for you, and a change in the weather." It was a new moon, Jennifer was born, and it was snowing in Pasadena. [Laughter]

Those sort of things happen so much with her--it's astounding. All three of my daughters were born the night of a new moon. Lester didn't need to predict them. The third one--I knew it would be Wednesday, the night of the new moon.

But that was astounding. That shook me up. It was more than just a coincidence. It happened too many times.

Levenson: Do you have any way of accounting for it that satisfies you?

N. Rowntree: No. I've become very interested in the moon and in the intuitive aspects of life.

Rowan and I worked on lookout towers when we were first married. The first one we had was up in Lake County. It's not in existence any longer--it was burned down. It was built in 1906. 
N. Rowntree: Lester came up there and camped down below. She drove up in her jeep. How old was she then? That was 1958. She drove up and camped.

Levenson: She must have been about seventy-nine.

N. Rowntree: Well, she drove her jeep to Lake County by herself, and she camped out at the foot of our rock. We lived on Pinnacle Rock --worked for the Forest Service. I don't know how Iong she was there. She took photographs of our lookout--I'Il send you one. I think it was one of the last Christmas cards she made. Do you have any of the photographs?

Levenson: Yes, we do have some.

N. Rowntree: Good. That was one of the last times I ever saw her use a camera. Her eyes were just getting too bad to focus and make the adjustments.

Once a day, she would come up the hundred and twenty-five stairs that spiraled around this rock--it was an old volcanic dike or something.

Anyway, she would come up and spend the evening with us, and just tell us about the place--sort of put us in touch with things we had overlooked. She had a way of doing this, without being--she never gave the impression that she knew it all. You know how people in their early twenties can be--she would be able to give things and we would be able to take them without being offended by an older person telling us. I suppose we were very sensitive then [laughs] and unsure of ourselves.

One memory I have is of the ring-tailed cats who lived on the rock. We had one we called Mrs. Ringy--evidently had young ring-tailed cats--and Lester, after a very short time, had Mrs. Ringy sitting in her lap and eating out of her hand. We'd never been able to go outside and have this cat come. They had long, very beautiful tails--striped. She would come and sit on Lester-you know, walk over her. Lester would just sit very quietly. She just had a way--

On the desert, I saw that too. Birds would come right up to her--and animals. She just has a way. I think people feel that too.

Levenson: It was certainly true with the television crew that came down with me. They were drawn into her life in a way that was very impressive and very touching. 
N. Rowntree: It's hard for me to see this as a member of the family. You have the usual family strife and things. It's been a long time since I've talked to anyone else about her.

Her Influence on the Family

Levenson: Did she contribute to, or soothe family strife, in your opinion? [Pause]

N. Rowntree: I don't want to get into this area. I don't think there was a lot of family strife, except I think there was some between Harriette and Lester. That was the worst. So she was sort of involved in it. Her way with most of it, I think, was to stay out of it--just back off and--

Levenson: You know you have control over the transcript.

N. Rowntree: It was a funny thing. It was as if my generation got along with Lester but the in-between generation didn't.

Levenson: I think that's quite usual.

N. Rowntree: That may be typical. People told me that that was pretty typical, but I used to get involved in it and be angry. Lester never seemed to. She would be angry but she forgot things.

Jennifer

Rowntree:

She would tell Harriette how she felt about her. Then she wouldn't say anything else--just keep quiet about it--calm-then she'd just forget it.

N. Rowntree: It was a very difficult time when Harriette and Cedric moved in with her. I think the outcome of that has been very good. She must have been eighty-nine when they moved in with her.

Levenson: That's right--about ten years ago.

N. Rowntree: I was thinking at the time Lester was still independent; she was still able to live alone. The only problem was she couldn't drive. She could get along all right. She got around all right. Lester did what she had always been doing--she was still working in the garden. I felt that it was kind of sad that she would become dependent on them and she has.

She stopped working in the garden, she stopped--but then, she has aged physically a lot more since then. I really had 
N. Rowntree: nothing to say about that. But it has worked out. I think the outcome has been good. Lester has had to make an adjustment and so has Harriette. I think they've both done admirably.

Levenson: One of the things that's most impressive for me was when, so unfortunately, she had that fall in May, I think, and went to the hospital and to the nursing home. Harriette said to me, "It's been a learning experience for her." I think it's one of the most remarkable things I've ever heard, that at ninetynine plus, you could have a serious accident like that, go into heart arrest--and she must have deliberately made a change in her attitude and gone on learning. That, to me, is one of the most extraordinary things I've ever come across.

N. Rowntree: There's no reason we can't ever stop--we don't stop learning. Things are just different. The central nervous system has slowed down and our short-term memory functions in a different way. I can see that in lester.

There's no reason why a person will stop learning, but things have to be presented differently. If it's a dramatic and emotional enough situation, there's no reason why Lester can't learn and go on. I think it's because she's open to the situation. She always said, "Keep your pores open" and maybe she's still able to do that. "Keep your pores open and keep listening."

I came back--I told her I'm at crossroads and I have some decisions to make. She said, "Don't force things. Let it happen." I need to hear some of the basic things and get in touch with her again. That's good advice for living and maybe she still uses it--she's still following it.

I think also the hospital experience may have been very stimulating. She has been alone a lot, and your whole project has probably been interesting to her.

Levenson: I hope so.

N. Rowntree: Did she seem very interested?

Levenson: She was for the day that we were working with the television crew. But it tired her out and she slept just about the next day completely through, and was not accessible. Then, on the last day, I wanted to go and say goodbye.

Harriette said, "She's out of it. Do what you like. You won't disturb her." I went down and Lester was very pleased to see me. 
N. Rowntree: Jennie brought her back a bouquet from the Hill--one flower of every kind, and gave it to Nannilester. Lester thanked her over and over. She thanked me for coming to see her, over and over and over.

Levenson: Did she talk about death at all with you?

N. Rowntree: Not this trip. Not this time. She has talked about death a 1ot.

Levenson: I know.

N. Rowntree: She didn't this time. She wanted to know when Rowan was coming. I think she will be here when Rowan comes. [October,1978] It's as if she's waiting for something. I don't know what it is. I'm not convinced that she had heart arrest. She's fallen since then a number of times.

I guess she's especially important to me because she was the first woman I was ever really close to. It's different than a mother relationship. I asked her in 1956 if she would be my grandmother. She said yes. It's just been a very special relationship.

Lester and Imogen Cunningham: "They Passed and Touched"

N. Rowntree: Meeting Imogen Cunningham was a moving experience--seeing the two of them together.

Levenson: Tell me about it.

N. Rowntree: Imogen came down and photographed--I remember them out on the deck together--these two--I mean, Nannilester was older than Imogen--they were out on the deck overlooking the ocean and talking about the garden. It was just marvelous to see them together. Somehow there's a feeling that they must have a lot in common--lots to talk about, but they didn't talk much. They just sort of passed and touched; went on their separate ways.

Jennie's in one of the pictures Imogen took.

Levenson: I'd love to see that.

N. Rowntree: I have one at home. 
N. Rowntree: I never had very many women friends until recently. My friendship with Lester has given me something to strive for in other relationships with women--a depth and a quality. I realize that Lester will not be alive forever. I guess I've been searching for older women because they have so much to give me and I have, hopefully, something to give them.

Levenson: That's a very interesting comment.

Shall we turn the tape off for a minute?

N. Rowntree: Okay.

[Tape off. A coffee break]

Quaker Background and Spiritual Eclecticism

Levenson: You mentioned that divorce was against Quaker religion.

N. Rowntree: That's what I was told in the family. Quakers just didn't do it.

Levenson: I wanted to ask you if you had any comments on the way the Quaker background of both Lester and her husband has affected the family--whether it's come through to these younger generations?

N. Rowntree: I guess her husband, Bernard, was a rather rigid person. Strict Quaker. Lester took in a lot of other things--eastern religion-and has really made her own thing.

I belonged to an organized church for a while. About the time I met Lester, I had let go of that. I just realized that today. When I came to college, I let go of the old--in fact, I was angry at my church.

Levenson: Which one was that?

N. Rowntree: The Episcopal church. In Orinda, they had ousted a man who was really a terrific person, and I was very angry about that. He was very important to me.

That was some time before I met Lester--but as a kid, I was out in the country a lot. I spent a lot of time outdoors and was very curious about things--and I didn't get the answers in Orinda. Somehow, I've never gotten on the right track. 
N. Rowntree: Being with Lester pulls a lot of things together. I think spiritually, a lot of things were pulled together for me.

She has what she calls the "It Is", and it is always with her--I can get in touch with that out of doors.

The Hill became a kind of spiritual center for a lot of us. Certainly Lester, Rowan and I, and Heidi. It was a spiritual place, and the remodeling of the Hill disturbed that. But it's true today--it's still true. I've had to let go of that as being the only place and search for new places because I wasn't sure I would be back there again--I wasn't sure if Lester would be alive--and I have expanded my search for my own spirituality, if you want to call it that.

The spiritual center of the Hill, for several of us, has moved up, above the house. Maybe to the Torrey pine, or up above a little further--I think the setting's just beautiful. There's something special there. It's not just sentimental-I get something special there.

J. Rowntree: Yes, there's something very special about that whole mountain. It's very beautiful and it has a feeling of Lester's spirit. She's the whole mountain or something like that.

Levenson: Did you ever read any of her children's books?

J. Rowntree: Yes, I did. They were very good. One of them took place up in the Sierra Nevada and it was very, very moving. [Little Turkey] It's a very nice book.

Levenson: She's so contemptuous of them--she calls them potboilers.

N. Rowntree: Yes.

Levenson: But I read them all, and I responded, particularly to the last one, Denny and the Indian Maglc. I liked them all.

N. Rowntree: It's so hard to capture Lester just sitting in this room, with the tape recorder. 
"I Always Feel Her There, Stretching"

Levenson: It's hard to sum up somebody who's been active for so long, but what do you feel were Lester's major contributions?

N. Rowntree: This woman is sixty years and one day older than I am. So, I came into her life relatively late when she was in her late seventies. I didn't know her when her books were being published. I just know a lot of the stories about things that happened. I saw her impact on other people. I don't know how I can answer this question.

Levenson: The effect on other people.

N. Rowntree: If you do that over ninety-nine years, one person has quite an influence. I know with me, Lester really encouraged me to trust my intuition and do what felt right. In times where I got off the track, I could go back to what Lester had said and I could right things again. It's changed my life several times. I don't know where I'm going today. I really came back here to touch Lester again and it just was wonderful to see her and to be on the Hill.

I guess for me, I know that I have to do what's right for me--not for somebody else. Her whole life has been an example of someone who changed when she was about fifty.

I always feel her there, stretching. For me, there's always the urge to be stretched and to move on. I think with Rowan and Lester, his brother, I don't think they would have chosen the fields they would have without her influence.

Levenson: Geography.

N. Rowntree: Rowan has a master's in ecology from the school of forestry here. His doctorate was on Bolinas Lagoon. It's geography, but that's what he was involved in.

I'm sad that my children have not seen much of her, but we did move away. I wish Sussi was here today--Sussi was very moved to see her.

Levenson: Perhaps we could talk about that a little bit. I know that Lester's very frail now.

N. Rowntree: In a way. She got out of bed the other day and moved over to her table to eat. She grabbed her walker and went charging across the room. I just had to laugh! It was like the last time I followed her off the Hill in her car. 
N. Rowntree: She went off in that jeep--it was the same way. She just charged. I could not keep up with her. She had a doctor's appointment in Monterey, and I was to follow her so she wouldn't get lost. She was lost--she got out onto the freeway. She didn't know where she was. She really couldn't see very well. But Lester drove like that.

To see her get out of bed was kind of funny. It was the same. She was going to eat, and she just went right toward it.

She is frail. She's going from an old woman to an ancient woman. But her spirit is still there. It's just so nice to see her.

Levenson: Well, she is going to die and you've brought your children to see her. Harriette told me that it was a very moving experience. If this is too intrusive, we can take it off the transcript. But I've had feelings that this was a wonderful thing, that four generations of the family could be together and could learn something about natural death--death at home.

N. Rowntree: I promised Lester that I would do all I could--many years ago-to keep her on the Hill. I'm really glad that she's there.

She got up and went outside the other day. I think Lester sometimes becomes confused about where she is in the downstairs room. [Lester Rowntree lived in the upstairs apartment until her fall in May, 1978.] She's much more accepting than I have ever seen her. She feels that it's a family center at the Hill. There were a lot of children--there were five children there the other day. It was noisy upstairs.

She said, "I'm happy and content with each day. Each day is beautiful." She may have her complaints, but she's made a marvelous adjustment, I think, living with Harriette. There was a lot of conflict between them. I think she's become very accepting. I've never seen her sleep so much. She used to complain about not being able to sleep.

She's gotten very small.

I don't feel I'm adequately answering this question.

Levenson: I'm so glad you're here, Jennifer. Do you want to say anything about your great-grandmother?

J. Rowntree: Sure. I think, when we went to visit her last week, Sussi, my younger sister, was very upset that she was going to have to 
J. Rowntree: die. She didn't want her to die at all. She just wanted her to keep living, and she was very upset about that. I talked to her for a while and told her that Lester had lived a very long and rich life. She'd done all the things that she wanted to and she's very happy right now being on the Hill.

I told Sussi that Lester wants to die because she's just living so long that her body's getting so bad, and she can't move around the way she wants to. When she dies, her spirit will still live on--and that's the way she wants it. So it was okay--Sussi felt better.

N. Rowntree: Heather's nine. She didn't like the idea of the spirit hanging around. [Laughs]

J. Rowntree: I think Heather's a little too young to understand very much.

N. Rowntree: I think the children were frightened to see her. They had been told that she's in very bad shape and so forth.

I don't know how you felt, Jennifer: I wasn't shocked to see her. Lester's just gotten ancient. Something very nice about it. She's just an old woman, that's all. I think we tend to isolate our old people. We isolate our children. In this country, we're all little groups of isolated people-expecially the old people. We're not used to seeing the very old.

I'm really glad my children have been able to be with her and see her this way, and know she's the same Lester. She's just old. There's nothing wrong with being old.

Levenson: Absolutely.

N. Rowntree: We felt we had to come this summer. I really didn't expect to see her again.

\section{$\underline{\text { Reminiscences }}$}

Levenson: You were going to see what stories you could remember about Lester.

N. Rowntree: They may be things I have to write you.

We talked about gardening a little. It was a lovely garden--blooming all year around. Some times of the year, it 
N. Rowntree: would just have this haze of Mediterranean flax over it--just sort of a haze of yellow all over. She would say the garden looked terrible, but it always was beautiful.

She would get very frustrated with things like ivy. She had ivy on one bank and 1t would take over too much; she would get very irked with that.

What was the other stuff up the Hill? She would put in things and they would thrive there too much. Everything seemed to thrive there. Things would overdo themselves--things that were a dwarf somewhere else or poor, small little things that would be put in on the Hill and would just go crazy. She would get very exasperated with them. I think they felt good there [laughs]--I think a lot of people bloomed there.

J. Rowntree: What about the rattlesnake grass?

N. Rowntree: Have you heard about the rattlesnake grass?

Levenson: No.

N. Rowntree: It's a family story. You know the grass that grows on the south coast--it's all over now. It has long pods on it-rattlesnake grass?

Levenson: Yes.

N. Rowntree: She imported that from where?

J. Rowntree: Peru?

N. Rowntree: I don't know. She brought that in to the south coast area-Carmel to her hill and it's all over now. I do not remember that grass as a child! In the forties. I do not remember seeing that grass until around the sixties.

Levenson: But she was very careful, as a rule, with exotics, wasn't she?

N. Rowntree: Yes. She really hated the pampas grass--it's planted all along the highway. And mesembryanthemum. She hates that whole group of things. It's in her own garden today.

She's been pretty acceptant of other people using her garden--Cedric has a lot of vegetables. I think she pretty much ignores--she's just not aware of her garden. She's aware of the pines, and the sky, and the clouds--she can see those things. And the ocean--birds. 
N. Rowntree: But from the inside of the house. The birds weren't there but she was aware of them--what was going on, even though she thought it was winter the night I was there. She could still see the tree and the clouds. I got side-tracked--

Levenson: Other stories about Lester.

N. Rowntree: Yes, there was another one.

J. Rowntree: What about the ones where she would tell about lying in her bedroom and all these wild animals--mountain lions--would come down--and deer--would come into her room when she was sleeping or just lying there, because her room used to be in the back of the house--and they used to just come down.

N. Rowntree: I have seen that so I have always believed her. I have seen foxes right up behind the house. I guess they would come right in, stick their heads in the door. Can you think of any more?

J. Rowntree: What about the time--I always remember this one thing--it's not really a story, but once, when I was younger, she told me that her way of getting an animal to come over to her was just to look at it, stare at it, and look into its eyes, and just think about nothing else. Just concentrate on the animal so much that they got your sort of ESP. They felt it and they just came over to you. You didn't think about anything else. If you started to think about something else, then that would just break the spell. I don't know--I can't really explain how she said it, but it was something like that.

I think when I was younger, I used to try that--it never worked for me. [Chuckles]

N. Rowntree: But you have a very good relationship with other animals-horses. And domestic animals.

I wonder if she does that with people? Her ESP message is very strong.

Levenson: She's very famous in certain circles. What does she feel about this, do you know?

N. Rowntree: She never talked about it very much. I'm not sure if she really believed it. She just did what she was interested in and wanted to do, and that's the way it came out. She never talked about it. She's a very modest person. That's why it's hard for me--I guess I think of her as my grandmother, and it seems other people know her in a lot of other capacities. 
N. Rowntree: It's still kind of surprising to see how well known she is. There are a lot of dimensions to her--the horticultural, the author of children's books, all her personal relationships-in her life just on the Hill alone.

Levenson: The Hill is a living demonstration--was very early--of what you could do with California native plants in a garden.

N. Rowntree: Yes. And she's been a living demonstration of what you can do with life. Another fascination I had with her was that you rarely hear her criticize anyone. She looked for the good things in people.

If she got bad vibrations from a person, she just didn't have anything to do with that person. She looked for the good in people and I think she drew it. She was looking for the high note.

It's kind of symbolic that Rowan and I went to a mountain top. I find I'm looking for that in my life--maybe in a small way. That was an inspiration.

[Tape off]

Levenson: You were saying about Lester--

N. Rowntree: This is something I haven't thought of before either, but something I do when I feel lonely, I don't usually run to other people. I get outside. Lester was in touch with the "It Is" and the force of nature, and I don't believe that she was lonely.

For me, if I get in touch with the feeling of loneliness in the right setting, confront it--then it's acceptable. I can feel alone in the universe and know that we all are alone and I am comfortable with that. Then, when I'm with people, I don't feel lonely with people, which for me is the worst kind of Ioneliness. I think Lester could live alone and she was content there, and acceptant, and she was not alone because her spiritual world is very real to her and the world of flowers and animals is all part of it.

[Tape off]

Levenson: You were going to tell me how Lester found the Hill.

N. Rowntree: They lived in Carmel, in the Highlands, straight down the hill, toward the beach. She used to walk up above there and, 
N. Rowntree: at that time, it was above the tree line. It was quite a bit above the tree Iine.

The way the Hill is up further, where some of us in the family get the feeling the spirit of the Hill has moved up--well, the way that is up there was the way that Lester's hill used to be. She used to go and sit up there and she just had a feeling that that was the place she would live someday. Somehow she acquired the property for a very small amount of money and contracted a friend, I think, to build the house. I suspect she was in there helping him.

Levenson: I'll bet she was!

N. Rowntree: It was during the Depression. All those things in the house like the kitchen doors--are they there any more?--it's combed wood. This fellow did that himself, I think. She used to have a dining room table--I think the stereo may be on it--it's covered with cloth. That is a combed wood table and this fellow did all that--a very rough, rustic place. It was what she wanted. And very nice natural wood floors, and a fireplace.

She chose to live there. That was her choice. The right spot. She built the house she wanted. Lester's been a very independent woman for about forty-nine years now. [Laughter]

Levenson: That's quite a story, isn't it, when you don't start till you're over fifty?

N. Rowntree: When you don't start until you're over fifty. It's been inspiring to me. I went through a period where I felt time was running out. I had to make changes and do it now, and I think of Lester. There's no hurry. But she's always an inspiration.

Levenson: That's a wonderful way to end. Thank you so much, both of you.

J. Rowntree: You're welcome. 
INTERVIEW NOTE

Heidi Rowntree Melas, with Erika Rowntree: She Gave an Example

Heidi Rowntree Melas and her daughter, Erika, were interviewed on a broiling hot day, October 4, 1978, in their charming house in Los Gatos, south of San Francisco. Heidi was married to Mrs. Rowntree's younger grandson, Lester, and has continued on excellent terms with the Rowntree family since her remarriage. The bond between Heidi and grandmother Lester was a little slow in forming, then grew very strong; they shared an interest in spiritual things--philosophy. "We could comunicate about certain things --which I felt was something precious and very rare" (p. 238). The special relationship between Erika, a great-granddaughter, started perhaps when she was born in Lester's bed, and all the animals from around the Hill reportedly came to greet the new baby. This story is the strongest example in the volume of Lester Rowntree's ability to inspire mythic tales--a rare quality in these times.

Commenting on Lester's charismatic quality, Heidi feels that part of it came from her broad range of interests, ". . . she was a fairly universal person in the Renaissance sense, and this is something rather unique" (p. 244). Heidi, unlike Nancy, found Lester critical of everyone. She thinks Lester was proud of herself for being a liberated woman, that she shared many feminist ideas, but was too traditional in many ways to fit in any of the several categories of the women's movements. "So I don't think you could call her a feminist. She just happened to find her own way of life, and was comfortable. She was lucky that she was able to do it--it almost seems like a miracle, but I guess she was very determined and strong-willed" (p. 255).

Heidi promptly returned the edited copy of the transcript with few changes. It was then final typed, proofed, and indexed. 
SHE GAVE AN EXAMPLE Heidi Rowntree Melas with Erika Rowntree

\section{A Daughter-in-Law from Salzburg}

Levenson: Thank you, Heidi, for letting me come down to Los Gatos, and sit here with you and your daughter, Erika. I'd like to ask you a little bit about your background--where you were born and so on?

Melas: I was born in Salzburg, Austria and went to school there. Ever since I can remember, I had the desire to come to America. I don't quite know why, but I think it has something to do with the American Occupation. There were all these nice Americans around who gave us chewing gum and candy [laughter]. All the Austrians were very serious right after the war and everybody was very poor.

I think from that time on I was very interested in America and $I$ also had some relatives here already. I wanted to come and study in America, and I already had the visa--I was going to go to Berkeley. Then I met my husband, Lester, at the time he was in the army in Germany, in Augsburg.

He had a very good friend whom I met first. I was working-at that time, I had a part-time job at the Austro-American Society in Salzburg. This friend of his came there and wanted to find a place for his younger brother to stay. So we kind of got acquainted a little bit and became friends.

One day he introduced his friend, Lester Rowntree, to the and I guess very quickly everything happened [laughter], and I didn't come here as a student, but I came here as the wife of Lester.

The Grandmother-in-Law: "Somehow We Found a Common Wavelength"

Levenson: When did you meet Lester Rowntree, your grandmother-in-law?

Melas: I met her very shortly after coming to America. In fact, I'd heard a lot about her before, of course, and I was really curious about her. 
Melas: So we just went to Carmel, I think about maybe one or two weeks after we came to California. I remember that at first I was quite intimidated by her, to tell the truth. She was very articulate and kind of overwhelming--she talked a lot and talked very much with my husband all the time, and I felt a little bit excluded. of course, my English wasn't too good at the time. It was generally a little bit difficult for me to get into this new family.

I guess maybe she didn't realize it at the time that I really needed some help. It took a little while. I was quite frustrated because I couldn't get close to her.

We stayed there [Carmel Highlands], actually, for quite a while because Grandmother used to go to the desert to Southern California every winter. She was already eighty-five at that time. She would get in her jeep and just leave for half a year, drive down; so she wanted us to stay in her house and take care of the house and particularly take care of the garden--do all the watering.

She gave us lots and lots of instructions on how to do it, particularly the vegetable garden was very, very important and was all full of New Zealand spinach, comfrey, and very healthy things like that.

Anyway, through this experience of gardening with her--and she worked everybody very hard--I'm sure you've heard that before [laughter]. We had to lug up these big sacks of seaweed from the beach. She wanted us to do certain things which were important to her.

But shortly before she left, I can't really remember exactly how it happened, but somehow we found a common wavelength. I discovered that she was very much interested in spiritual things and I was too. So we started to have very good conversations about philosophy, and about her attitude and her beliefs towards life--kind of metaphysical questions and things like that.

I just realized that there was this wonderful person who was very much interested in the same things that I've been interested in. I had not found another partner to talk about these topics in this country yet, so it was very, very meaningful for me to have discovered this side of her. I think this probably has been the basis of her and my relationship throughout the years. We could communicate about certain things--which $I$ felt was something precious and very rare. 
Melas: I always loved nature. I remember Grandmother kept asking me about the names of the flowers in the Alps. I just didn't know the names in Latin. I knew them in German but, of course, I didn't know the English names--so we could not really talk too much about flowers. But I've always loved flowers since I was a little girl because we used to take hikes every Sunday and pick flowers in Austria.

She always used to ask me what kinds of things I was reading and she was very interested in things I was thinking about. I asked her about books and I looked through her library.

One day we discovered that we both knew about Rudolf Steiner for instance, those kinds of esoteric people. We had a lot of very interesting conversations.

Levenson: How much would you say she kept or retained of her Quaker background --Quaker religion?

Melas: I really don't know. I don't think one could put her in any religious category. Perhaps one could call her a pantheist. For her it was all a manifestation of another world in many ways. She saw the spiritual element everywhere, and then she always talked about being in contact with these other elements that she was very, very close to.

\section{A Great-Granddaughter Born in Lester's Bed}

Levenson: Tell me about Erika being born in Grandmother's house. In those days, I think it wasn't as much in vogue to have a home delivery as it has become lately.

Melas: Well, I guess it was quite unusual at that time. When we realized that Erika was on her way, we were in some ways a little bit shocked because we weren't prepared for it. It wasn't planned at that time. I was still [aside]--sorry, Erika--[laughter]-that's the truth! It was a very good surprise, however.

At that time, I was not very well adjusted yet in America. I was quite homesick, I think. Grandmother was in some ways like a mother figure to me. I felt comfortable with her. I don't really know whether she was the one that suggested it. But anyway, at some point, it came out that one could have home delivery in that area--that there was a doctor who would come.

Lester Hazel used to live down the street--she was a friend of Grandmother's and a midwife. I guess she was quite a pioneer 
Melas: in this approach. She was for natural childbirth and for breast feeding, and even for having the baby at home. She also knew about this Dr. Fry in Monterey, who was willing to go along with the home delivery.

In fact, the story goes that he went up and down the coast all the way to Big Sur to deliver the hippies' babies. He was the only person around to do that. I went to him and he was quite willing to go along. I saw him once in the beginning of my pregnancy, and then he left on a six months cruise or so as a ship doctor. So I did not see him again for several months.

But I knew I was healthy and everything was fine. Then shortly before Erika was supposed to be born, Dr. Fry returned. I went to see him in Monterey and I remember driving down from San Jose with Harriette and Jennie. I felt very awful that whole day--I felt very lonely and homesick and really depressed. I guess that was a first symptom that something was going to happen.

Anyway I went to Dr. Fry and he checked me and everything was okay. We talked a little about the last preparations. He assured me with the first child usually things go so slow, so if something should go wrong, there would be enough time to get me to the hospital. It was very reassuring.

I went back--we lived in the San Jose area at the time--so I went back and as soon as I got home, it was about seven o'clock in the evening, I felt the first pains--labor pains--and it turned out that Erika wanted to come. Later on, when we realized that it was serious, we called Dr. Fry and he said, "Well, just go back to bed. Call me in the morning. Take an aspirin."

I tried to do that, but I couldn't go back to sleep. Then at midnight or so, we called him back and he said the same thing. But then we realized that he did not realize that we had gone back to this area. He thought $\bar{I}$ was up at the house where Erika was to be born.

Towards the morning--very early morning--we started out driving to Carmel. We got there--I can't remember--it was four or five o'clock in the morning. Now the big task was to wake Grandmother up, who had taken her sleeping pills and was just deeply, deeply asleep. So it took a long time to get her out of her bed and get me in there [laughter]! But anyway, we managed.

It still took a long time--a little after eleven the next day, Erika was born. Everything went well. I mainly remember how very peaceful and beautiful it was to lie there in the bedroom with the curtains all open and it was foggy outside. You could see the 
Melas: Monterey pines and the shrubs--and I could just look up the hill and there was this little creature next to me--this newborn baby --and it was just a very, very beautiful thing.

The idea of having a baby in these beautiful surroundings is what really appealed to me--it was how it should be. I didn't realize much of that, but there were all of these stories when we drove up during the night, there was a fox, I think, that crossed our way--then all kinds of animals apparently were around, and Grandmother observed too, that all the animals came to greet Erika.

As it turned out, Erika has really had a great love for animals all through her life. I can't remember what other animals--

Erika

Rowntree: Deer.

Melas: A deer. Even in the house there was something.

E. Rowntree: There was an owl.

Melas: The owls were always around. Well, Grandmother was always surrounded by animals. So it was a very, very nice experience to have a baby there and everybody was very cooperative. [Laughter] Except Erika was not an easy baby, so it took me a little while to get back to normal. But it was very beautiful.

Grandmother used to tell Erika beautiful stories about when she was in the mountains for weeks at a time and didn't have any contact with human beings, and that she could--first of all, communicate with the arimals and the plants. But then also that she could just feel that there were all kinds of spirits-nature spirits--around her, and she was very much in communion with them. Lester had a very close relationship with Erika-she probably doesn't even remember that too well.

E. Rowntree: Yes, I do!

Melas: One winter we stayed in her house in Carmel; then fairly soon, we moved to Oregon where Lester, my husband, studied. Grandmother came to visit us, I think two or three times. She was already in her upper eighties.

We had this little old house with just a big, fairly wild garden--we rented the place. She came--Erika was about-- 
E. Rowntree: Three.

Melas: --three or four, about that age. I still remember Grandmother for hours--it seemed like whole days--she would just lie in the grass or crawl around with Erika through the plants, through the bushes, and point out little things to her and tell her these fascinating stories.

There were these two creatures--they were almost similar in size--not quite [laughter]--having a wonderful time! I think she enjoyed these visits very, very much and we certainly did. Her days were always outside, crawling around with Erika.

Levenson: You were going to tell me about a trip you took with Lester.

Melas:

Grandmother invited us to come and see her at Twentynine Palms one winter. Erika was--I think she was about four months old. So we drove down there and she stayed with Josephine Jackson, a good friend.

Josephine wasn't there at the time and so we stayed with Grandmother--I think about a week and it was a very, very beautiful experience. Grandmother would take us out during the day and we would take walks into the desert and she would explain all the plants to us. Then at night, we would hear the coyotes--and she was very good at imitating the coyotes. She was very fond of doing that for us.

Unfortunately, when we were there, we didn't experience the snow, but she was always raving about the desert covered with snow. Actually, she was snowed in, I think, one winter for quite a while.

During that week we would pack a picnic and then go to some special spot where there were very special plants. We would just have our picnic there and she would explain everything to us.

Erika--poor little baby--was dragged along everywhere- and Erika was very, very difficult at the time. In fact, she was-I don't know why--but she was an extremely difficult baby--for about two years, she never slept through the night. She was just awful--cried all the time.

I gave her all the attention--I was living just for this baby. But Grandmother was very critical of that, and that came out during the visit. She thought I should just let her cry through the night. 
Melas :

Apparently, she had also talked to some of her friends about this difficult baby, and everybody said I should just be much more cruel and discipline the baby more. So we had a little bit of a conflict there, but of course, I felt pretty guilty about it. Whenever the baby cried, I would go and see that she's quiet because I took it personally--I was embarrassed when my baby cried--so that put a little bit of a strain on those days. But it was a very nice time--and Lester was so full of enthusiasm about the things while we were there.

I guess it was quite a tradition with her--going to the desert. She liked the openness and the quietness of the desert. Then it made such a contrast to her hill, too.

Particularly at night, she loved to go out and look at the stars. She would talk about the stars to us. She had a very intense communion with nature there--even though everything was very bare. Then there would be all of these little creatures coming out. There was a lot of 1ife, actually.

She would always say, "Well, when you first go to the desert, it looks very dead and bare, but then when you just sit still somewhere for a while, it starts coming alive and you see al1 these little creatures coming out." I remember that impressed me very much. She often said that, also to Erika, when she was little--there are all these elves and dwarfs and nature spirts around. All you have to do is be very calm, sit still, and wait. They will always appear.

Troubles with Sleeping Pills and Old Age

Melas: When she visited us in Oregon, at night we had quite a problem with her because already then, she couldn't sleep very well. I remember she was sleeping in the bedroom right next to ours and at night we would hear all these strange noises, and in particular there was the sound of all these pills dropping-one pill after another--[laughter] so she had a lot of trouble at night with her sleeping pills and tranquilizers.

By the way, she always felt very gullty about that. She often talked to me about that, because on the one hand she so much believed in everything being natural, including nutrition-including the things you eat and you put into your body--her body, of course, has always been very important to her because she was very hard on it. 
Melas:

She told me, in a very apologetic way about these experiences she had in the hospital after an eye operation--how she got hooked onto drugs and how bad she really felt about it.

I was trying to think when the big transition came. Fortunately, I came here-Grandmother was eighty-five then and for about five years or so, she was still very, very sharp. And she was physically very strong. I remember how she would lift up really big pieces of rock [gesturing] and she would work in the garden--she had really an incredible strength for a little old lady, which she actually was.

Also she had a lot of endurance and that was amazing. Then at some point--and I don't really know when exactly--it was certainly during the time that we were in Oregon, she started to deteriorate.

I think also it came at about the time--well, I guess Cedric and Harriette realized that she couldn't stay by herself anymore. Then she didn't want to drive anymore--so it all happened more or less at the same time--she just turned into a different person in many ways--just, I guess, old age. It's very sad.

of course she had times still when she was very clear and really her old self, and even very recently, there were short times when you could sense the old Grandmother there--the old Lester.

But it is really quite a change. I remember that when we were first there, there were all of these people who kept coming to see her--people from universities, botanical groups, whatever --just lots of friends--it seemed like they were paying homage to her, and it was very interesting.

Levenson: I was going to ask you why they came, because obviously she drew people. I wondered what the people were looking for in Lester when they came to see her. What do you think?

Melas:

I think she is very different from the average person. She has a very strong personality and I think in many ways, she was quite an egocentric person and a genial person, and somewhat of an eccentric.

Aside from the knowledge that she had and her many interests, I would say--not only in botany and in vegetation, but also in philosophy, in literature--she was quite well-read, and intellectually very active. I think all of that--she was a fairly universal person in the Renaissance sense, and that is something rather unique. 
Levenson: Did she go in much for homeopathic medicine?

Melas:

Yes! Very much so. That was one of the topics we talked a lot about because my brother is a homeopathic doctor. She very much believes in it and she remembered it from her childhood. I think in England this is now again a very, very strong movement. This is why she felt so guilty about her sleeping pills and tranquilizers, because she basically believed in these natural remedies and this is why she had them all growing in her garden --all these herbs.

She knew very well what worked for what ailment. But I think she had a lot of health problems in her life. Maybe she felt that these homeopathic things can only go so far, but she has done too many other treatments too, so sometimes the two don't go together.

You have to go all the way and all your life only use these natural things because your body, I guess, cannot handle these other very strong medicines.

She had several operations and was in hospitals and got these very strong treatments. I tried many times to talk her into trying to stick it out, taking a soothing tea at night or something natural--or then we tried with wine--a glass of wine or beer--different things--but she always had quite an obsession with sleep. She would dread not being able to sleep, and so she would rather just go to the sleeping pills.

But there was quite a conflict in her on this subject. She didn't believe in them and yet she took them.

\section{An Intellectual Reminder Within the Family}

Levenson: How do you feel she influenced you and perhaps your husband-and Erika can speak for herself. Do you want to, Erika?

[Pause] Maybe later.

Melas: I feel that Lester has always been very demanding in an intellectual way--or let's say she has high standards of people in general. That came through in her conversations and the kinds of things she liked to talk about.

In many ways, she has been rather what you would call even a little bit arrogant--things have to be at a certain level. I have always respected that very much. Also, I think she herself is a very disciplined person, intellectually--and in every respect. 
Melas:

I think she had quite a unique position within the family too. It was a little bit hard on the boys because Grandmother always expected much more of them than perhaps the parents did. I think this had quite an influence on the boys--maybe not immediately, but take the case of Rowan--he took little detours in reaching his goal--in fact, Lester did too. He [Lester] fooled around, he went through all the usual high school things that go on in America. I don't know--this is my feeling about it--I don't know if this is correct--but I think Lester [Grandmother] was always sort of an intellectual reminder within the family. I think she's much more intellectual than Cedric and Harriette.

I know she has always tried to influence both of the boys in that direction. I don't know about Pat now--I have no way of telling. She was certainly an inspiration; they knew what she expected and so they wanted to live up to her expectations.

That may have something to do with the fact that they both went back to school and pursued studies that were somewhat related to what Lester did.

Levenson: What was your impression--obviously, you weren't in this country or born at that time-of Lester as a mother to Cedric?

Melas:

I'm sure she was a different mother--not a typical mother in many ways and she probably always had very high expectations of her son, which put a lot of pressure on him. There are these stories of him running away from the boarding schools he was put in.

She probably had all kinds of plans for him. I know one of these plans was that she wanted him to become a veterinarian and he didn't, and I don't know--maybe she was a little bit disappointed about that.

With me, she was always very open and critical even of her own son--also of her grandsons--of everyone, really--because she felt I was an outsider--maybe, in some ways, she felt a little bit of an outsider too.

I know a big problem for her was always the relationship with Harriette. There was a lot of mutual resentment--a lot of rivalry, I'm sure. Perhaps she had another kind of person in mind for her son. But it comes back, again, to the fact that she was very demanding of people, and she was rather intellectual herself and very disciplined, and she wanted everybody else to be like that. She wanted, probably, her son to be pushed in that direction by his wife, too. 
Melas:

Then, of course, times were very different. It's very difficult for me to judge. But I just know that there has been a lot of resentment and that perhaps this is one of the big problems of Grandmother's life--because she is basically a very ethical person and has very high moral standards. Yet she used to say a lot of things that don't quite fit into that picture--and she realized the incongruity herself.

Levenson: Can you give me a "for instance"? An example?

Melas :

She was very, very critical of the way Harriette brought up the boys. I would say that most of the things that Harriette did and believed in were wrong, according to Grandmother. But then this is a rather common thing between a mother and daughterin-law. It was mutual, too, I think.

I think mainly she was resentful because she wanted more of an intellectual influence on Cedric probably, and the whole family--the boys, too. This is why she felt she was the only one who pushed everyone in that direction--and she resented-that this was not the case in the family in general.

Levenson: What about Lester's influence on you?

Melas:

On me, I think she has a similar influence. She took very much interest in my going back to school and doing studies in languages--and she liked the idea of my teaching very much because she knows that I'm fond of children and just knows that this is a very important way of influencing people in general-inspiring the youth.

Even today, when I go back, she always asks, "How's your teaching going? What kind of students do you have? Do you enjoy it?"--and these questions. So I think she had a very strong influence on all of us. And Erika thinks so too, huh?

Levenson: Do you want to say something, Erika?

E. Rowntree: She always dominated us, and I'm kind of scared of her; so I think that's why I'm a little bit shy--because of Grossmama.

Melas:

You think so?

E. Rowntree: Yes. I kind of figured that out. She always asked me, like what books I was reading, what I was doing at school, what I liked best--usually what I hated--I said, "I don't like math; I like reading." She said, "Well, I was awful in math," and she told me all these different stories how she used to talk during math and had to go through all these different punishments. 
Melas:

Levenson:

Melas:

Levenson:

Melas:

Levenson: Did you read her books and articles?

Melas:

Levenson: How would you estimate her achievements--especially as a writer?

Melas:

We11, she let people know whether she approved of their interests and their activities or she didn't! She was very straightforward there. She would let you know. This was good.

Obviously, she was what one might call an authoritarian personality, to use jargon. But I'm interested in how she got heavy gardening labor out of the boys--out of her son, out of her grandsons, even out of her granddaughters-in-law.

What were the sorts of sanctions she used to make you lug that seaweed up the hill, to make you dig or build the steps? What was her power over everybody?

I think one of the reasons is that she did it herself. She gave an example. If you see an eighty-five year old lady lifting up these big rocks and digging over the earth--doing these hard things--you can't stand by there and say, "I can't do it." Just impossible!

Perhaps it's her own background--being from Europe and befing from a somewhat different era--at that time, the younger people just followed the orders of the older people--that's just the way it was.

I don't think she was very much in favor of this whole permissiveness that was going on in America at the time. But I think maybe it's her own example.

Did people resent it within the family?

I think so--up to a point. Carmel is such a beautiful place, and you wanted to go there also to enjoy yourself. You didn't want to work all the time! It was almost like you would feel guilty if you would sit there and just relax and enjoy yourself when there were still things to do.

But then I remember how wonderful it felt when everything was done and you sort of let down. [Laughter]

Some of them, yes.

It's quite a while ago that I read them last, but I think she's a very good, talented person. She has a nice style and her children's books are very inspiring, very beautiful. I can't really judge her botany books very well, but I'm sure they're excellent. 
Melas:

Levenson:

That's a winning combination--imagination and discipline.

She's a very imaginative person and of course that comes through in her writing. She's disciplined, too. Her books are wellwritten--beautiful--and she, of course, has always written with a lot of enthusiasm because all these things she really loved to write about.

Lester's Cooking: Chicken, Chard, and Comfrey

Levenson: What about Lester as a homemaker or housekeeper? Nobody's ever talked about her cooking.

Melas:

Her cooking was interesting. [Laughter] I remember the first meal she prepared for us on the first day we visited. We had to pick up the chicken in Carmel and it had to be from a certain place. She liked chicken very much. She prepared it very well, she used a lot of herbs. I remember she particularly liked tarragon. Her salad dressing would have a very strong taste of tarragon.

I still remember all these jars with tarragon vinegar that she was so proud of. Then she loved salads very much. Of course, everything she had in her garden. But the most important thing with her salad was that there had to be a lot of comfrey in it. She told me all the things that comfrey was good for. I don't remember, but I think one of the things was arthritis-it's sort of a good cleansing thing for the body, so I had to put lots of comfrey in the salad--then sorrel--she had lots of different herbs in her garden, and she knew, of course, the significance of each herb, what it was good for.

One very, very good thing she used to make is a fresh mushroom soup. She told me the secret too. It really tasted like fresh mushroom--and it had almost a little bit of a nutty taste. Then she told me how she made it and it was very simple. All she did was use a lot of mushrooms--fresh mushrooms--and milk--and grind it up together in the blender. Then put herbs in it--a little salt and pepper--it was very, very good.

But mainly I remember her chicken, which was very good--it was just baked in the oven with herbs on it. Then potatoes-she had potatoes in the garden, too--these very tiny potatoes which I like very much because--I remember them from Europe-spring potatoes, the little ones. In this country, you can't buy them. She had them in her garden. 
Melas: Then she always had lots of Swiss chard which we ate, too. [Laughs] It's funny because I was always the only one in the family who really enjoyed eating all these greenies--I guess they had so much of it that they didn't enjoy it any more, but I liked her Swiss chard and her spinach very much.

Another thing in her garden--she had this constant fight with the gophers. I don't know if anybody else told you about them?

Levenson: No.

Melas:

She had a very special technique. I'm sure she, like so many gardeners, has gone through all the different methods how to get rid of the gophers. She finally developed this method of cutting up little pieces of carrot and putting some very strong poison--I think it was strychnine or something like that--she put that inside the carrot and then stuck it in the ground.

And it really surprised me because it was so incongruous! She was so much against spraying and poisons in the garden, and there she would put out this very strong and dangerous poison.

Travels: Definitely Anglo-Saxon Oriented

Levenson: After you were in Oregon, then did your husband, Lester, come down to Berkeley to take his Ph.D.?

Melas: No, we went to Austria for a whole year. That's where he wrote his dissertation and got his Ph.D.--from Oregon, at the University of Oregon.

During the sumer we went to Europe quite often. In fact, at that time Grandmother helped us financially also. She was very, very generous. I think she made some inheritance from a brother and she distributed it among her grandchildren. Perhaps it was even our very first trip back to Europe after I'd been here for three years. She helped finance it and she felt, too, that it was very important; in fact, she was always very much in favor of the younger generation going abroad--going somewhere else, getting away from California.

I remember one summer she actually wanted to come to Europe with us, and she had made plans to go to England. We would spend some weeks with her in England and then we would go on to the continent--to Austria mainly. 
Melas: I can't remember what the circumstances were. Anyway, she called it off at the last moment. She always had this desire of going back to England once more, as long as she was still in fairly good shape physically. She had a very, very strong urge to go back once more to see the Lake District, see all the flowers-that's one of the dreams she had.

But I think this was a time when, really, her health started to fail--she became weaker. It was very unpredictable whether she would make it or not, so taking a big trip like that just seemed a little bit too chancey. She decided herself, not to do it. It was, of course, a disappointment to all of us and most of all, to her.

During the last five years or so, she hasn't talked about it much any more. I think she overcame this urge to go back to England, or she realized that it might have been disappointing. I tried to prepare her in case she would go, that things had changed very much and she would probably not find the childhood paradise that she remembers. Maybe she realized that herself and wanted to leave it alone.

Levenson: That raises a couple of questions that I wanted to bring up. How much of a cosmopolitan was Lester? As far as I know, she never went on the continent. She was born in England and she lived in America.

Melas: Aaah--somehow I didn't realize that, but yes, now that you say it, she's never talked about being anywhere else, even though she has talked about the Alpine flowers. I guess I assumed that she had been in the Alps at some point, but you're right, she hasn't. Or she'd certainly remember.

I don't remember any specifics. So she has gone back to England a number of times and then, she's traveled all over America. Aside from that, I don't know.

She's of course well-read. She has read a lot of literature from other countries, too, and she's certainly interested, but she's definitely Anglo-Saxon oriented.

\section{A Lack of Political Awareness}

Levenson: How politically aware was Lester?

Melas: Politically, I don't know how she was before, but since I know her, she has always been extremely liberal--almost one-sided. 
Melas:

If a person was not a liberal, that would be bad. She couldn't see the other point of view. She was very judgmental.

But I don't think she was politically very interested during the time that I knew her. She was rather apolitical and she often said she didn't go down into Carmel much at all any more. Even when she was around eighty-five or eighty-six, she would come back and she would say, "Oh, it makes me sick to see all of that!" and "This world is terrible and it's so depressing." And she compared always with the past.

At this time, I think she really lacked the understanding that things are changing and it hurt her very much, and she just did not want to keep up any more at that point. So she kind of withdrew. I think with politics too, even though she always had lots of interesting magazines and she was well informed in ecological matters, but it was all one-sided.

She liked very few politicians, however. She only liked the extreme liberal people.

Levenson: What magazines did she subscribe to other than horticultural and ecological magazines? Did she have any general ones?

Melas: I think it was called The New Statesman; then I.F. Stone's review--what was it called?

Levenson: He had a newsletter.

Melas: Newsletter, yes. Then she had the Saturday Review. She had the New Yorker--for some reason she liked that very much--she even liked the cartoons in the New Yorker!

Levenson: So do I. [Laughter]

Melas: But for Grandmother, you know, she is not a cartoon type of person but she liked that. I guess that's all I remember.

But she had so much mail always--and very interesting things. Then she had something like the Farmer's Almanac from England--sort of peasant rules about gardening and weather. Just different, interesting things. 
The Grandchildren's Divorce: Intellectually Acceptable, Emotionally Difficult

Levenson: This is a touchy matter and I don't want you to feel pressed, but how did she react when you and your husband decided to separate?

Melas: I guess we were all cowards. We never really told her formally. For a long time, it was back and forth--my husband was gone and I didn't know whether we would get back together or not, so we did not inform her about these things. I knew that it would hurt her very, very much because she was always very fond of all three of us, and she thought of us as being a unit and belonging together. So we just didn't want to hurt her.

For a long time we didn't say anything--I never really told her. Maybe because Harriette asked me not to, because at that time she was taking care of her and she said she would be the one who would hear it all the time and would have to suffer from it. So I never said anything.

But then Harriette informed me that she had told her and that she knows about it, so now Grandmother keeps asking me whether I am remarried, whether I'm still married to Lester-she forgets about these things. Somehow, I don't think it's that important to her at this point.

We had a number of talks about it. She has been divorced herself and she realizes that there are certain situations when you just can't force things. Then I tell her that Lester and I are still on very good terms and will probably always be friends. We'Il always have something in common and it is very important that we ourselves have a happy life or create a life of our own. She does not believe in staying together just for some unimportant reasons. So I think intellectually she understands or she would understand it if she remembered, but emotionally it would be difficult for her because she is so fond of all of us.

I really don't know whether she realizes what is going on and whether it bothers her at this point. I think now it really doesn't bother her any more. She forgets it most of the time and she lives in a different world. She floats and sort of comes back to reality now and then. Then she's just halfway on the other side and these things are not important on the other side, so I don't think it matters at this point. 
A Family-oriented Feminist

Levenson: Did you talk with Lester about women's liberation?

Melas: Yes. She certainly was very proud of herself in that respect and she realized that she was one of the first liberated women, probably, in this country.

She was fond of telling people that she was the first lady who wore pants in a certain situation. I think she was living with her father and her brother in some university town on the East Coast [Haverford] and was the first one who would wear pants and people would be just amazed and stare at her. So, I think she had this desire to be different.

Probably she resented a little bit being a girl. This comes up in different ways throughout her life and certainly in the reflection of choosing her name later on. It's obvious.

Then the kind of life she led after her divorce. That's obviously not a typical woman's, but I don't think she did it in a political sense. It just was right for her and somehow she was strong-willed and strong-minded--she was able to do it. And she didn't care whether people called her feminist and so.

I remember she certainly told me many times I shouldn't spoil my husband the way I do. Of course, I came from Europe and I'd always seen that the father or the husband is the king and all the females in the family are there to serve him and to make everything comfortable for him. of course, I didn't know anything else, so she told me many times I shouldn't do this-and Harriette did too, by the way. So little by little I got influenced and I guess I adjusted! [Laughter]

I'm just trying to think whether one could call Grandmother a feminist or not.

E. Rowntree: [Softly] Why?

Melas: Because in some ways, she is quite traditional, too. Like later on again, she has become very family-oriented, and very often she asked me whether I didn't want to have another child? She talked about her own family--how beautiful it was to have all these children at home, and she idolized her mother very, very much. Her mother must have been a wonderful person but very traditional, in a very traditional female role. She respected her mother very much. 
Melas:

So I don't think you could call her a feminist. She just happened to find her own way of life, and was comfortable. She was lucky that she was able to do it--it almost seems like a miracle, but I guess she was very determined and very strongwilled.

But I think she certainly would believe in a lot of the feminist ideas--that women should have all these freedoms and should have equal opportunities. I tend to think she herself was a little resentful of the fact that she had to take care of her father and her brothers and that she did not get a university education, whereas her brothers did. Despite all of that, she achieved what she did. I think she would be very much in favor of a number of the feminist ideas.

\section{A Shared Love of Mozart}

Levenson: What about music? Did you have a common bond in that?

Melas: Yes, certainly. She was very fond of music. She loves Mozart very much, who is my favorite composer, too. In many ways, I think she loves all classical music, but she particularly likes chamber music and more delicate music--concerti and things that are more delicate. She absolutely adored--I think I introduced her to this Mozart concerto for flute and harp*, which is a very, very beautiful piece and it seems to me very heavenly, very spiritual, about as spiritual as music can get. Grandmother enjoyed that so much and she would ask me--whenever I was there --after teatime, which is before dinner--when she would lie on her little couch there--to put on some music.

I always knew what she liked and she always enjoyed it very much; so I usually put on violin concerti and chamber music. She would just lie there and enjoy it.

She also liked Mahler which surprised me a little. At that time when she said that, I was not very fond of Mahler yet--in the meantime, I have become more and more fond of him and I really love him very much now. I've never liked to hear Mahler too much in a home, particularly in a small house, because it is such strong and intense music, and I feel that in

*K. 299 . 
Melas: a home, chamber music is more appropriate and Mahler somehow overwhelmed me, so I didn't appreciate listening to Mahler too much in her house and the house was very small at the time.

In the meantime I've changed and I really appreciate Mahler much more. I think you have to become more mature to appreciate him. But I remember she told me this story that she was--I think, it was in Mexico. She was near a little village and somebody was singing a tune--it was a very striking tune-it was a simple folk tune, but it was very striking, and she remembered that tune. Then she went to a concert later and heard Mahler's First Symphony and she thought she recognized that theme--or at least there was a very, very similar theme in Mahler's First.

I think she was very fond of that aspect of Mahler, of these little tunes that pop up here and there--Mahler's light side.

Then she liked baroque music very much--Bach, Handel, she was very fond of Handel--but I guess her favorite--I really am curious whether her favorite was Mozart before we started to talk about Mozart--we decided that Mozart was sort of the purest musician. To me, Mozart is almost absolute music--it's very pure and it's very close to the way I imagined--well, the essence of music, spiritual music--and Mozart, to me, comes closest.

Grandmother had the same feeling.

$\underline{\text { Coda }}$

Levenson: What other stories do you want to tell? Shall I turn the tape off for a minute?

Melas: I think there are some stories that probably Erika could tell.

Levenson: What do you like to remember most about your great-grandmother?

E. Rowntree: Just her way with animals and nature.

Melas: Erika, you just wrote a composition about her in school. Remember that?

E. Rowntree: Yes. 
1. Arboretum, University of California, Davis. Lester Rowntree and Botany class, 1962.

2. Josephine Jackson and Lester Rowntree, in desert, 1965.

3. Crosslegged in her living room.

Lester Rowntree at 96. Photo by Margedant Hayakawa.

4. February 17, 1971. At back of Lester's house by the Torrey pine she grew from seed. Lester slept out here until recently. As Skee Hamann says, "This expresses her -- the vitality, the puckishness, the bravado." Photo by Russ Cain, Monterey Peninsula Herald.

5. Lester Rowntree, aged 94.

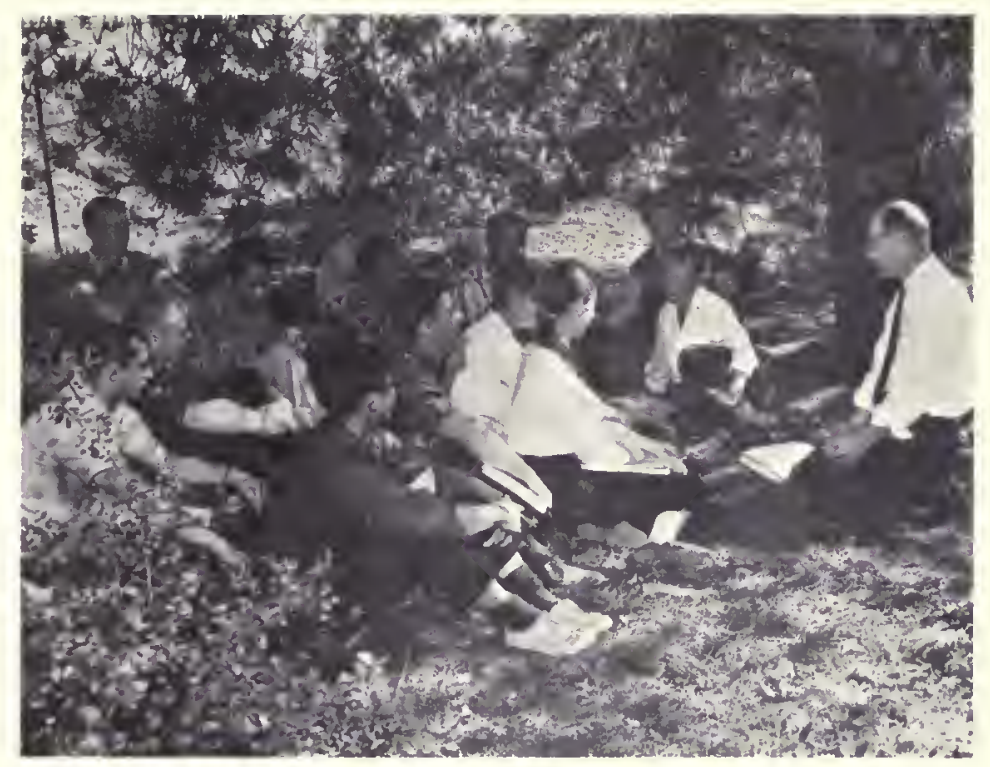

1 .

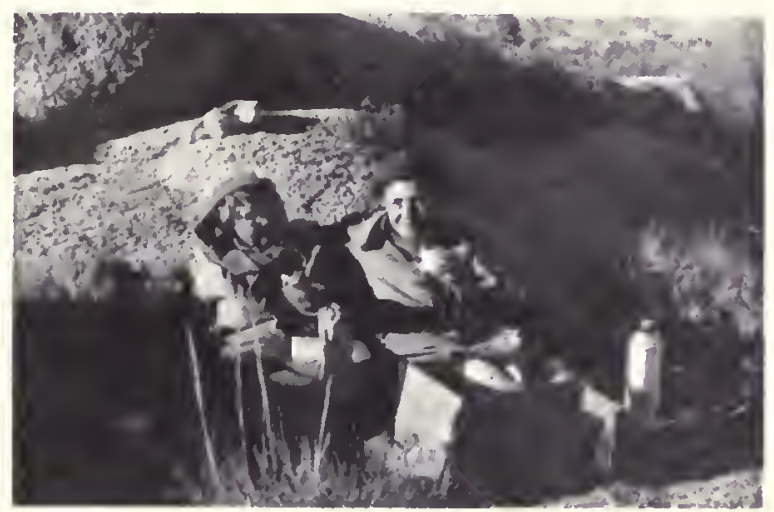

2 .

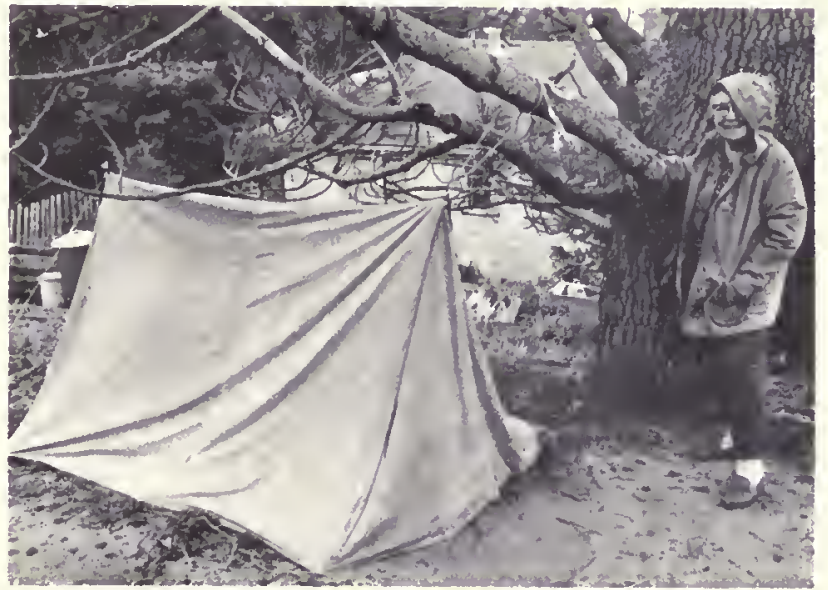

4 .

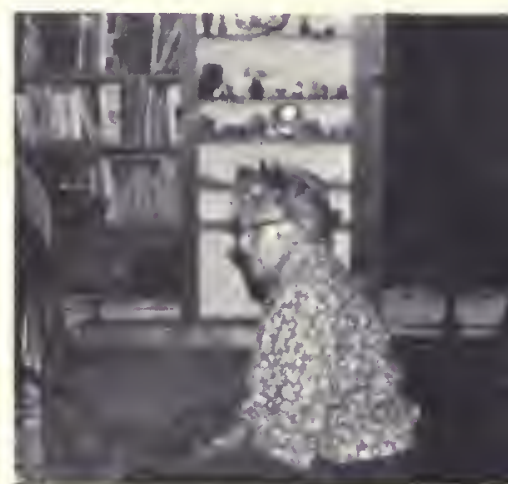

3.

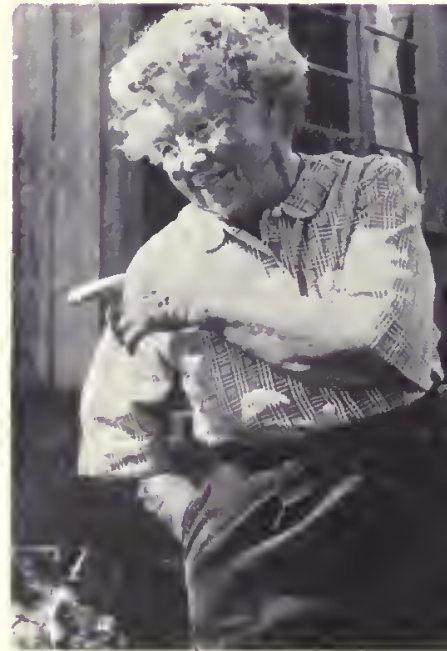

5 . 

Melas: I remember you were always struck by the idea that Grandmother used to run away from school.

E. Rowntree: She told me that her parents used to get mad at her. Her father, especially, would get mad at her and come and tell her to go to her room without any supper, or something like that. She would be very mad at him because she was just having fun, like being outside and playing with her brothers. So she would just run away for a few days and camp out in the forest until everybody was worried about her and came looking for her. Everything was forgiven! [Laughter]

Melas: Do you remember that story about the biscuits? When she would run away--she told me she would always take so many biscuits. She was always fond of biscuits, so she would take a good supply of biscuits along and she would stay away as long as the biscuits lasted and then she would come home. [Laughter] 
INTERVIEW NOTE

Skee Hamann: Lester Rowntree: Fresh, Free Currents of Life

Skee Hamann first met Lester Rowntree twelve years ago in the course of her research work for Charles Cleveland Johnson on eminent pioneer botanists. A friendship developed quickly between the Hamanns and Lester. Many regal commands followed for the Hamanns to leave Middletown in Lake County, California and drive the two hundred and fifty-odd miles to Carmel Highlands. And a long correspondence was begun. A copy of Lester's last letter written shortly before her ninety-ninth birthday can be found following page 277.

Skee, as she asked me to call her, lives on a little hill above Middletown on land which she and her husband gave to the Audubon Society as a bird sanctuary and memorial to their daughter, brutally murdered in 1968. The mountains which surround Middletown harmoniously frame the hill and its wildlife. For company, Skee has all the wild birds that she feeds and protects, and two charming young geese whose mandate is to scare away abandoned cats which have begun to prey on the birds. Their mellifluous conversation which rarely broke into honking formed a pastoral background to our conversation.

Skee's shelter's core is a mobile home with the wheels removed. A roof has been built over it which covers a corridor elegantly carpeted with pine needles, two small studies, and a space with a large green refrigerator and capacious bunk bed as spare room. This corridor is a perfect spot to display the drawings and naturalist collections made by generations of young students who have been introduced by the Hamanns to the pleasures and rewards of nature study.

Skee was well prepared for the interview. She had systematically talked with Lester on her visits to Carmel and had distilled the results of these conversations into a hundred page typescript manuscript, "Runaway," which is deposited in the Rowntree archive at the California Academy of Sciences. Skee has also published a number of articles on Lester Rowntree, notably one appearing in Fremontia*, journal of the California Native Plant Society.

*January, 1976, Vol.3, No.4, pp. 3-8. 
Like Ornduff and Roof, Skee feels that Lester and John Muir were in the same tradition and on the same wavelength. One of the qualities that makes Lester special to Skee is the quality of her close and patient observations of growth in the wild.

The question of the fire that destroyed Lester's writing studio is raised again (p. 270). Skee reports that Lester suspected the distinguished Quaker naturalist, E.K. Balls, a most improbably culprit. The value of the oral history record as historical evidence is validated rather than weakened by the discrepancies in our memoirists' stories. These discrepancies are a reminder to the reader that it is the responsibility of the user of records to evaluate the evidence according to the best standards of historical research.

The interview took place in one of Skee's studies on September 7, 1978 . We sat talking, surrounded by photographs of mountains and flowers that both Lester and the Hamanns had loved. The interview was an example of emotion recollected in tranquility.

Skee was prompt and helpful in returning the edited transcript, making very few changes. She also kindly sent me her typed transcript of all the letters Lester had written to the Hamanns. Both letters and transcript can be found in the Rowntree archive. 

LESTER ROWNTREE: FRESH, FREE CURRENTS OF LIFE Skee Hamann

First Impressions, 1966

Levenson: It's very nice of you, Mrs. Hamann--am I pronouncing that right?

Hamann: Yes, I'm just Skee.

Levenson: It's very nice of you, Skee, to let me come up to Middletown, California, to talk about Lester Rowntree. I'd like to know, first of all, a little bit about you, and how you became interested in Lester and became such a great friend of hers.

Hamann: It was Charles Cleveland Johnson, the New York botanical's official photographer for that great series, Wild Flowers of the United States, who insisted that I go to Lester along with these four other remarkable old botanists, who were still functioning as useful human beings in great age.*

It was a dream of his and he had more dreams than he could fulfill. I had done a year's research for him. He knew that our minds were on a sympathetic [chuckles] level. So he sent me to Lois Robinson, the widow of Lester's great favorite, the first Clyde Robin. You've probably had numerous recollections about that friendship?

Levenson: I've heard something--not a great deal.

*Edith Van Allen Murphey

Ruby and Arthur Van Deventer

Dr. Walter McDougall 
Hamann: Lois was Lester's closest friend for many years after her husband had died, tragically, gathering wild flower seed at white wolf in Yosemite at a young age. Lois was alone for many years and then, six years ago, marrled Chuck Klein, who had been at the Botanical Garden at UC.

Lester, my husband, and I became such close friends because, after our first visit, in 1966, Lester appreclated the similarity in our interests. We had both loved Slate Creek, Upper Leevining Creek below Mount Conness, which was Lester's favorite spot in all the Sierra, and it was also ours. Now it's trodden to death, but then it was peopleless. Quite a beauty.

We also shared a respect for wild creatures and an ability to sense their reaction.

Lester was very fond of my husband. He was interested in studying animals by their scat [droppings]. The first time we all went to Point Lobos, Lester was eighty-seven and galloped up the steps to show off. I'd say, "We're both show-offs, Lester!" She would say, "No, it's bravado." Her bravado would always make her run up the steps from that private beach at Carmel Highlands [Yankee Point].

Lester stooped over a pile of fox dung, expecting us to shudder or recoll. She bent down with her nose almost touching it and said, "Isn't it interesting? Isn't it fascinating? See how nature prepares seed by putting it through the wild creatures' digestive tract?" Then she sort of looked like a skittish colt out of her eyes at us, and I said, "You can't startle us, Lester. Huck is a scatologist, too." So as long as my husband lived, she would write notes, "Fellow scatologist!"

He was a practical joker. Once, on a walk with children who were friends, he came on a scat of coyote. The poor creature had eaten glass--quite sizable pieces--and it had gone through with no apparent injury. The scat was dried. It was many months old, so he wrapped it in tissue paper and put it in a pretty, white box, and sent it to Lester. scat."

I came on the post card just now: "Thanks for the delightful

Levenson: That's wonderful.

What were your impressions of her when you first met her? How much did you know about her before and where had you learnt it? I realize that's a lot of questions, all in one! 
Hamann: I knew nothing about her fame and her work, strangely. Charlie-Charles Cleveland Johnson--had been the first one to make me acquainted with her. I sent to the state library for her books and read those. What Lois Robinson had told Charlie and Charlie had told me was that Lester deserved continuing honor because she had sort of dropped out of the main stream.

When we first saw her, she was still working hard in the garden, right in the earth. She wanted people to know she still loved to have her hands in earth. I've quoted in a manuscript, of which you have the copy--"Runaway"--that she would snap if you said "dirt." "It's earth--dirt is what you sweep up in the gutter --earth is what we spring from." So she would be troweling away at weeds on her knees in the garden; then look up in surprise when her guests arrived. And she'd make a big point about keeping the door open in all weathers and sitting on the floor.

She took to me right away because when she sat on the floor and apologized, Huck said, "Oh, Skee does that all the time, so you don't have to worry about shocking her." That I always sat on the floor too made us close right away.

She liked the delicate little thumb-at-the-nose at convention, you know. [Laughter]

Levenson: Yes.

\section{"Runaway"*: How Skee Recorded Lester's Life}

Hamann: What Lester wanted to talk to me about was her life in the wilderness and plants themselves. So, in writing her life, I didn't go into detail about everything. I let lester pick the subjects. As strong-minded as she is and at as great an age as she was, eightyseven, I felt it was best.

Each time I did it the way [Hubert Howe] Bancroft taught his researchers to do when he began his histories--I took it all down in my own writing. I carried over from my years at Chico and UC my own brand of shorthand. If I reread it within a hour, even though

*100 pp manuscript by Skee Hamann, to be deposited in the Rowntree archive, California Academy of Sciences. 
Hamann: most of the vowels were left out, it was mostly just consonants, I could transcribe it all and type it all.

I found, since I was interested in what Lester was--how she became what she was and the flavor of her life--the humor and the wisdom--I would just ask a question or two and let it flow. That was in these wonderful letters that she wrote after ninety-six. It would just take the right question to unlock the gates, and the flood would come!

Estimation of Her Writings: Conservation

Levenson: How did her books impress you when you first read them?

Hamann: I was entranced because she so often had the same response as John Muir.

We had the great good fortune to know the High Sierra before it was overrun. It was not as pristine as in Muir's day. We started in 1932; Lester was still there. It was strange that we never met at our favorite campsite. She wrote, "These are the places I love the best." The High Sierra peaks, they're my heaven too. We always said the Sierra was more home than home. The two weeks that we had in the mountains during our working years were what we lived for all year.

Lester never mentioned to me the two book-length manuscripts on alpines and desert plants that are in the archives of the California Academy of Sciences. Margaret Campbell was so impressed with them that she asked me to evaluate them for possible publication. It was at the time that Margedant Hayakawa went through everything to have a background knowledge as she edited my story of Lester's life for Fremontia. I felt she was better qualified than $I$.

I think Lester was so wounded that they came back. That was why she never mentioned them to me--she never once spoke of them. I think it was a great blow to her pride--her Hardy Californians and Flowering Shrubs of California had received so much acclaim, and she knew they were very useful. I believe she felt these other books were the same. She always explained to me her not having written more by her photographs and the notes she took having all been lost in the fires. Actually, the archives have a great deal. 
$262 b$

Jhis raím weel be a

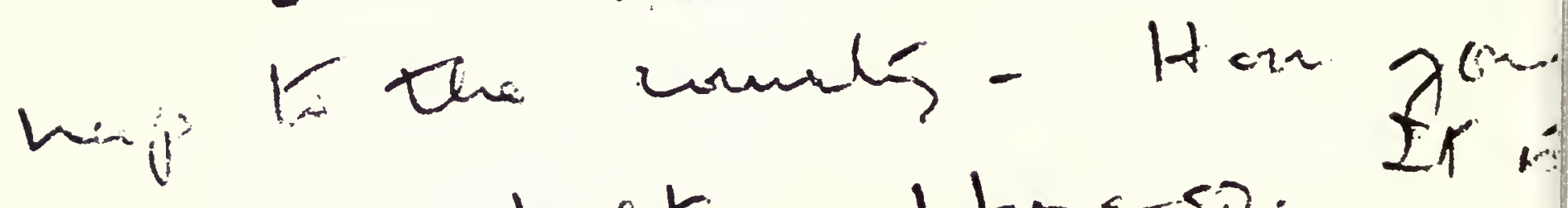
an wisel shelter, Itopeso. It a

cantin =

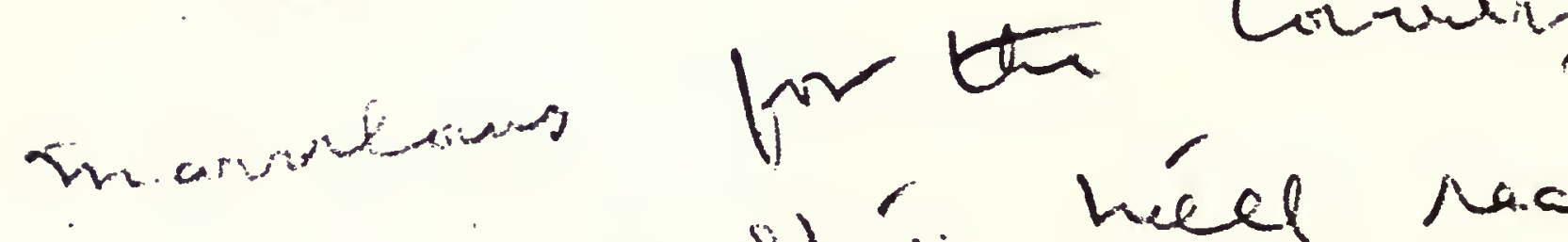
Har radiéx héel racel?

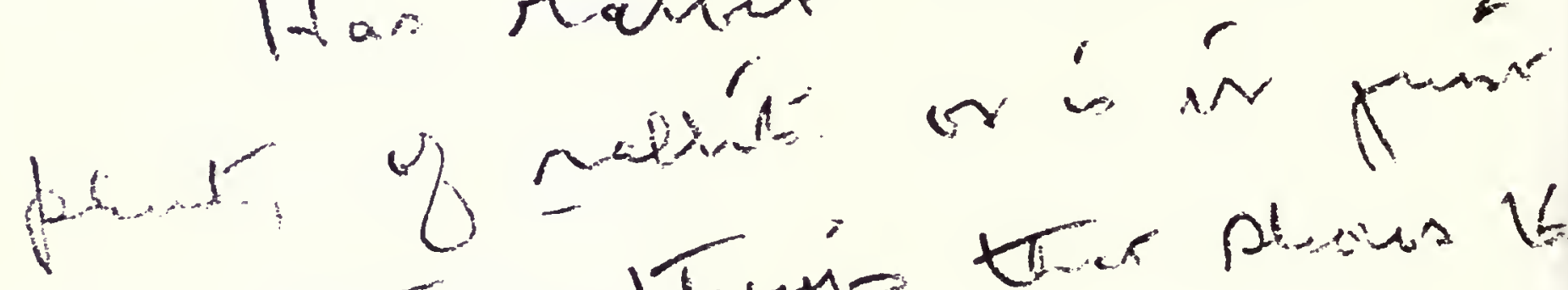

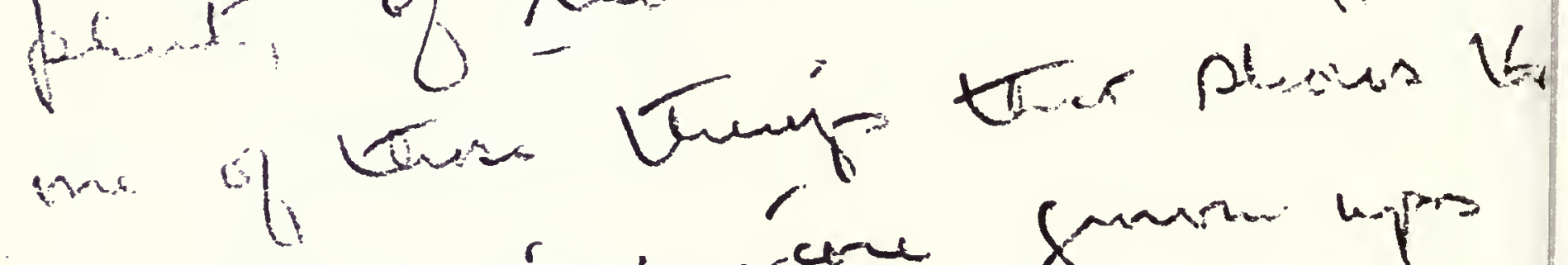
$\lambda^{-1}-$ han in unare Saman wp

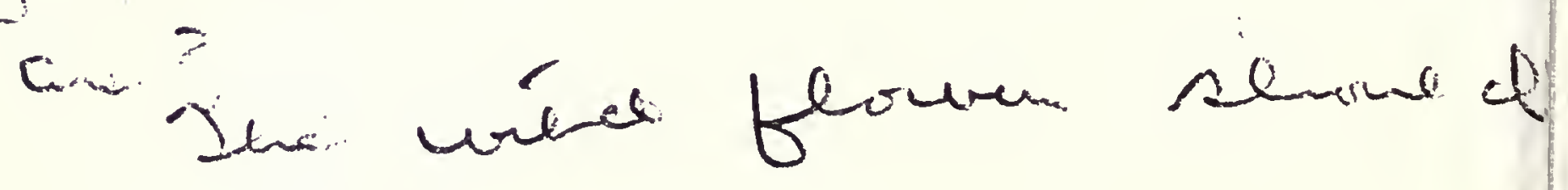
Le gaund this years. humia lore Lesté 
Hamann: There was a long interval of seven years there, I think, when she wrote just the four children's books--it was just the children's books that were published.

I think it was such a wound to her pride that they were not published that she sort of pushed it out of consciousness, and that is why she never mentioned them to me.

Levenson: That's interesting. She certainly showed a lot of pertinacity in getting some of her articles published when she was younger.

Hamann: Yes, yes, yes.

Levenson: What about her contribution to the conservation movement?

Hamann: Yes. I'd start first with conservation. That comes to my mind because her relation to very small children and young people, as well as older people, until just the last year or so, has been of such great enrichment and such a lasting influence toward conservation. As she says, we cannot conserve the beauty of our wonderful continent if we do not teach the young to be aware of it early.

She often says that at twelve, children are too old. We found that too. They try hard to see what it is that animates and motivates us and beg to go along, but the ones that have started at that age, can't keep it alive by themselves. They have to have adults with them on wilderness walks to absorb and transmit it to them.

An example--in World War II, Lester's particular contribution to the war effort and to conservation, was to load more than the legal number of children into her car.

You know her collecting car had just one seat. Before the days of camping vehicles, she had the idea of a van and had just a nicely upholstered leather driver's seat which was moved from the old car to the new. She said sometimes she had nineteen or twenty children sardined into her one-seated car.

She would take them to the ocean or the hillside. Just her enthusiasm--"Oh, see this--look at this star fish--see the anemone-watch the color there as the tide turns--or see this little salamander, how bright his belly is." She would bring in the scat too. [Laughter] She said children were locked out by the mothers who were working in the war effort--door key children. So she took pity on them and spent a great deal of time, taking them out and about so that they might be in some constructive occupation while they were left alone. 
Hamann: Then, of course, young people jousted for the privilege of coming --we said when we first met her that going to Lester was a bit like getting--you wouldn't say an appointment--an audience with Queen Victoria--because there were so many more people who wanted to see Lester than she could see.

She would write and ask us to come. We said it was a royal command; we had no choice! [Laughter]

Groups of young people would come with professors from colleges and schools and sit on her floor, and she would sit on the floor and charm them with her relaxed attitude. All of this carried over to the young what lester was living for--preserving--making people aware of the beauty of wilderness, specifically the wild flowers, and the importance of preserving it.

She says in one of her magazine articles you will have--I believe it was Countryside, written in the thirties--"Collecting is a conservation measure." She would go to plots that were to be bulldozed for real estate development or put under cultivation. She always made a point of saving seed for the birds, seed for resowing, and then, what was left was seed for the collector. Generally, she would try to scatter something sparse in another adaptable location.

It was she who helped save the Torrey pine--down toward San Diego. It's just a tiny place where they grow. They were found there by Charles Perry I believe, who was a collector for Asa Gray in the middle 1800 s, I guess. He went with the railroad survey--so it was around the fifties at the latest.

They were just being hacked away. Lester admits that her beautiful Torrey pine--if you had known her a few months sooner, she would have wanted to meet you under her Torrey pine. She used to give audience in her sleeping bag, under her Torrey pine that she grew--she said, "I managed to steal a two-inch one before we made it illegal to take anything." [Laughter] It's a great tree now, the one directly in back of the house.

Of course, she spoke at colleges. Her lectures were always slanted toward conservation. She lectured in every state of the union, and in England a great deal. By word of mouth, as well as by her books and by her close to a hundred magazine articles, she made vivid imprint of her values.

Then I presume that with botany, horticulture, the same influence carries over.

Landscaping never came out to any degree. 
Lester: "I'm Just a Botanical Enthusiast"

Levenson: Could we separate those?

Hamann: Oh yes, surely.

Levenson: Because Lester says that she's not a botanist.

Hamann: She says Carl Purdy, who evidently was a bit condescending to her when she was lunching with him at The Terraces above Ukiah at the height of his fame, said, "Mrs. Rowntree, you're not a botanist. You're just an enthusiast." She repeated that to me several times. "I'm not a botanist. I'm just a botanical enthusiast."

In my research on pioneer naturalists, I don't believe I found any who approximated Lester's detafled observation of growth of the plants.

John Bartram had tremendous influence on her. She mentioned over and over when she was governess for Christopher and Felix Morley at Haverford, before she went to Westtown school.

Levenson: Now, this is very interesting to me because I have noticed in the chronology that she graduated from high school rather late.

Hamann: Yes.

Levenson: '21 or ' 22 .

Hamann: Yes. I doubted it so, so I wrote to Westtown. In fact, everything in "Runaway" has been checked by Lester. If there was some ambiguity, then I checked it elsewhere too. Westtown said she was correct--that was the year she graduated. I had doubted it.

Levenson: I think it was 1902 .

Hamann: John, her brother, who died at just short of one hundred in 1969, spent most of his adult life at Haverford. He came as a student from England because they wanted him to introduce cricket. He played cricket all over the world. She said that when she went back to England on a visit--her graduation present from Westtown-his picture was all over the papers.

While they were still in England, when she was small, potentates from India would come and visit their home in the Lake District because they had met John and admired his cricket playing. 
Hamann: He wrote a book on cricket.*

John was a student at Haverford; then he taught at Hills School at Pottstown, Pennsylvania, when Lester and her father were there after the mother's death. But then he went to Haverford as a professor; stayed there till he retired; died there at just short of a hundred. His son is still there--another John.

Levenson: They have a remarkable history.

Tel1 me about Christopher Morley. The distinguished author?

Hamann: Yes. The Saturday Review for sixteen years. Felix [Morley] went on to be president of Haverford and Franklin Roosevelt's advisor, you remember. John Lester was a favorite of his.

The mother, I guess, was pregnant with her third child, Frank Jr., when President Morley asked John if his sister could come and be governess and help with the children. She was there for a year. She loved Christopher's charms and Frank had a great sense of humor. She lost track of Felix as he grew.

While she was at Haverford, on her days off, she would go often to John Bartram's garden outside of Philadelphia. I had two books of John Bartram's and his journals, and enjoyed his writings very much.

It was John Bartram, perhaps, who had the greatest influence on Lester. It was the plants themselves that were important to her and to him.

In her writing, she goes into great detail, you know, describing the alpines-how the little hair-like root can pierce the crevice in the granite and find sustenance there. She lived with the plants she studied, I believe, more than any of the others--David Douglas collected great numbers, but he was on the move so much, and he was harassed by the Indians so often, and by the necessity of keeping up with the Hudson Bay men when he would ride in their boat, that he didn't linger the way Lester did in the habitat of a given plant.

And, with her being on foot, or with her little burro, and with her poetic, mystical sensitivity, I would say that with her--

*John Ashby Lester (ed) A Century of Philadelphia Cricket, Philadelphia, University of Pennsylvania, 1951. 
Hamann: --as with me--growth is given the highest value. To me, it's the force of life--growth of wild life or forms of nature--and children. And the change in earth itself.

Reading Quaker books to understand how she was shaped, I think fresh, free currents of life is important to Quakers. I'm sure that her mind and perception were open and ready to receive this exchange, as she lived in the wilderness. So I believe that she contributed to what she said she set out to do--reduce the mortality of wild flowers in the garden.

She said often in her talks to garden clubs, which she had to go through to earn money to continue her work--she said the enthusiasm there in the lecture room would dissipate when she was gone. Human inertia would take over. There wasn't a deep interest to carry them along.

Maybe they'd get seeds and just scatter them out and forget about them. But for people who really cared, her writings--the hundred magazine articles and parts of Hardy Californians, Flowering Shrubs of California--really made it possible for people to erow them successfully because native plants are touchy. [Chuckles]

Horticulture, Landscaping, and Hybridization

Levenson: You were talking about Lester and botany, and now should we move into horticulture?

Hamann: Yes. It's a fine line where you stop being a botanist and go into horticulture. [Laughs]

When I wrote to Victor Reiter at John Thomas Howell's suggestion because he was the only living person beside Lester who had been present at the founding of the California Horticultural Society, he said, "Don't see what you want about horticulture in a book about a botanist!" And John Thomas said, "I was so busy with botany, I wasn't aware of horticulture at that time, so I can't give you information."

But Victor Reiter did say Lester, Alice Eastwood, Cora Brandt, Eric Walther who was at Strybing Arboretum, and Sydney Mitchel1 were present at the meeting--and perhaps others. But evidently, they were the movers. 
Hamann: The thing that people in horticulture seem to remember as Lester's introductions are ceanothus--Ceanothus impressus and Ceanothus gloriosus--one at Pt. Reyes and one down--not La Jolla, but south - - that I've heard spoken of the most.

Then she was doing a great deal of hybridization with gazanias at the time of the fires that destroyed her seed house and her records.

Levenson: What caused those fires?

Hamann: Let me just say one more thing, and then I'Il go to this. Her landscaping, of course, wouldn't be classed as horticulture. The only thing she really made money on beside her talks, were her landscaping jobs. She bought her place in Carmel with the proceeds of her first big landscaping job. She came over the rise of the hill, coming down the Santa Luclas, and she said intuition said, "This is it. But what will you use for money?" [Laughter]

And her first big landscaping job let her buy the land and then a man whom she thought was a carpenter but turned out never to have built a house before, took a rain check on her next job, and built the house. So her landscaping supported her and let her get on with the love of her life, botanical exploration in the wilds.

\section{California Native Plants}

Levenson: We haven't talked specifically about California native plants. We've talked in general about them.

Hamann: Alpines were her dearest love. And of all, Eriogonum ovalifolium.

Levenson: I know eriogonum--I didn't quite catch the rest.

Hamann: Ovalifolium--o-v-a-1-i-f-o-1-i-u-m--does that make sense?

Levenson: Yes.

Hamann: It grows on Mt. Conness.

Levenson: Isn't that beautiful? [Looking at photograph]

Hamann: [Pointing out on map] And way up here, a little later in the year, there will be a plateau that's almost the way the snow is packed now. Getting close to 12,000 feet, I think. 
Hamann: This little tiny plant, just a mat because it has only a few weeks to sprout, makes a lovely rosy carpet.

And sky pilot--Polymonium eximium--is on one of these cliffs [showing photograph] a couple of thousand feet above the glacier, just clinging there.

But her deepest response was always to the alpines. She loved to watch--she wrote that at ninety-six--it was all so vivid and important and fresh to her still--she loved to watch the alpines opening at the edge of the snow as the sun rose.

Levenson: Yes.

Hamann: But her knowledge--her ability to identify them still--in her nineties! I'd walk, when I was with her for two or three days, up in the Santa Lucias, and bring down a handful of plants for her delight. She would just rattle the names right off. It was astonishing how the botanical names were still imprinted in her mind.

I must tell you this one about the plants. Anecdotes kept coming up each time that I hadn't used before.

She could no longer remember the name of a famous botanist she met on a field trip at the dunes by the ocean toward the south. Lester was creeping over a large dune on her hands and knees, searching for a rare beach plant, all concentrated at the top--almost bumped heads with someone else, and it was a famous botanist hunting for the same plant. [Laughter]

I don't know if Margedant left it in the Fremontia article. Her crawling through the brush above the north rim of the Grand Canyon and meeting Rose Collum?

Levenson: I don't remember.

Hamann: They had heard of each other often, of course, and Rose Collum, by the way, Dr. Mac [Walter McDougall] said, thought nothing of walking from her home at the foot of Mazatzal Peak to Grand Canyon, 167 miles each way. She did it often--collecting all the way. Lester said she was like a hay rake, she took everything.

Lester was crawling on her hands and knees on the north rim of the Grand Canyon in thick, thick brush, and came up with her head above the brush, and there was another woman on her hands and knees, crawling through the brush. She looked at her and the woman stared back and said, "You must be Lester Rowntree!" And Lester 
Hamann: stared at her and said, "You must be Rose Collum! Nobody else would be such a nut!" Now, how's that for humor? [Laughter]

Levenson: I think that's just great.

Hamann: Their sociability was in the field.

All of her stories of friends, except for Josephine Jackson, were people working with native plants.

Personal Relations

Hamann: Now, the fires. Naturally, anyone as strong and loving of solitude, independent as Lester, would have friction in working closely with people because most geniuses work better alone, don't they? [Laughs] A great many, shall we say?

Levenson: Indeed.

Hamann: Lester suspected the gentlest, gentlest man who had done some collecting for her [E. K. Balls]. I met him on a walk in the Santa Lucias. I was there sleeping in my sleeping bag outside by preference, and rose early and met him. Then Alice Howard, at the Herbarium at UC [University of California, Berkeley] sent me xeroxed copies of his archives. It wouldn't have been possible for him to have set the fires--a Quaker and a selfless man. But that was Lester's feeling.

I imagine Harriette would have told you about the unhappiness with her one-time partner in the seed business?

Levenson: Yes, Lila Clevenger. There's quite a lot about lila in the papers in the California Academy of Sciences.

Hamann: Oh yes, yes. The strange thing is Lester never mentioned her name to me. She just had wiped her out of her memory. Harriette, when she was proofreading one of my manuscripts, inserted Iila's name. She said she earned it. [Laughter]

Levenson: Lila must have done a formidable amount of typing.

Hamann: Yes, and she was there while Lester was having the fun--she was filling the orders, answering all the correspondence, and doing the packing, I think. And Lester had--well, it was Lester's talent, of course--but she did have the privileged side of the partnership. [Laughter] 
Hamann: Evidently, the great compassion and sensitivity in Lester--when she's given that--it'as as the philosophers say, once you give loyalty, you cannot take it away. She gave loyalty at times that roused her compassion.

Lester was to have met our daughter two weeks after she was murdered. The tragedy affected Lester so deeply that she wrote once or twice a week for months.

Lester had--her mind was so responsive to our daughter's early death because our daughter and she had so many qualities the same and she envied the childhood our daughter had had. She used to say, "Oh, what a pririleged childhood!" because Lester's reminiscences always start with the impulse to run away from all the people, and servants, restrictions, the wall about the garden, and the rigid nursery rules of comfortable homes in England in her childhood. We told her of our daughter being allowed, at four, to run in the hills ahead of us. When we'd take her to the sierra, in the sub-teens, she'd often go a full half-day ahead of us on the trails. There were no people in those days.

Lester, who had been trusting, like our daughter, also had a deep need of solitude. Both of them charmed people so. Their charisma--they both had that very strongly--so they were always surrounded by people. Because of that, both of them had to have solitude.

When we told Lester that our daughter, who was living alone in a house over two creeks, five miles from here--at night, when she finished her moonlighting job that she had taken in addition to her daytime job, to pay the mortgage off her creeks, she would open her door above the creek and put out her hand with cat food in it, and the coons and the skunks would eat out of her hand.

Our daughter said communication with the wordless ones is so precious. That was exactly Lester's reaction. Some of the most beautiful letters Lester wrote at ninety-six were about her experiments with communicating with coyotes and foxes.

The similarity of the two of them--one very young and losing life and one living on beyond any desire to live--but having the same reactions and the same effect on people, brought us very close to Lester too.

Levenson: You have called Lester a leader. Perhaps I would phrase it slightly differently and say that she had enormous ego strength. One of her grandsons laughed and said he got a tremendously annoyed letter from his grandmother once that said, there's no room for a selfish 
Levenson: person on my hill. It was when he was living there [laughter] and he realized that what she meant was there was no room for two selfish people.

Hamann: No, no one could last there. And they used to beg me to come. I wouldn't have thought of doing it because, as I told Cedric [Rowntree] over the phone a couple of days ago, I've had the cream. I've been able to stay at a distance and these periodic meetings we have are so intensely loving and congenial. Cedric and Harriette have had to do the dirty work through the years and have the friction that is inevitable with so strong an individual, who had started running away at two to find her heaven--solitude on top of a mountain. And being cooped up in a house with somebody else--she just couldn't stand it.

Leader perhaps in that her thought inspired other people. Dr. Marion Hall came up to me when I gave my talk on Lester's life at Morton Arboretum three years ago. He was the director there and he waited until everyone was gone. He said, "It was Lester who turned me to botany. I was set for a career in aviation. During World War II, I bought Hardy Californians and Flowering Shrubs of California. They saw me through the war. I took Lester's books, my backpack and every leave, went to the Sierra. Lester saw me through the war."

Levenson: That's wonderful.

Hamann: Then there are many, many more.

Levenson: $\mathrm{Oh}$, indeed.

Hamann: And Kenneth Taylor, at Las Aromas, in Monterey--he's in California native plants--he has a native plant nursery, said, "It was Lester that turned me to a life work in native plants." Of course, Bob Robinson, Lois' husband, who died so tragically, started the first Clyde Robin business--used to sit on Lester's doorstep, she said, by the hour, picking her brain, and she encouraging him.

Leader was that interpretation for me; not someone who would go to meetings and say, now we have to do this. It was just the vitality and enthusiasm and the sincerity and her zest for life.

Levenson: I think that's a wonderful tribute. Shall I turn it off for a minute?

Hamann: Whatever. If you're short of time. I'm enjoying it. 
Hamann: One of the greatest honors I ever had was when she asked me to go to the annual meeting of the California Horticultural Society and accept the plaque for her that they awarded for her outstanding contributions to propagation and conservation of California wild flowers. Mai Arbegast suggested that if Lester couldn't come herself, she might ask one of her family. Lester said, "No, ask Skee Hamann. She and I are of the same spirit."

Levenson: Oh, that's lovely. That's really lovely.

Hamann: She has told me things that I'm sure she's never told any of her family because, as I say, I have purposely kept this on this plane of communication. I've stayed with her perhaps a week at a time sometimes. But everyone who's tried to stay longer, ends up hurt, and leaves.

Levenson: Except Harriette and Cedric.

Hamann: They can't. [Laughs]

I have been able to ease things there a little bit, I think. I tell Lester over and over how much I appreciate how well they take care of her, and I think it has pleased them.

of all Lester's botanical friends, Ralph Hoffman seemed to have lingered with the greatest warmth in her memory. They seem to have become very close. They collected together on San Miguel, all the Channel Islands--there was a fisherman whom they used to pay to take them out to the Channel Islands, where--not full of naval ammunition then as they are now, nor developed--there were one or two ranches on them.

But San Miguel was their favorite. I have the story of Ralph Hoffman's fatal fall there on their collecting trip, but I hadn't put it in because it seemed to me personal--something Lester had conveyed to me. I think one of the deepest loves of her life was Ralph Hoffman. They seemed extremely congenial.

She said, with such a far away look in her eyes--we were looking out over Point Lobos--"Gee, he was fun! He had the most wonderful sense of humor." 
Strong Influence of the Quaker Tradition

Levenson: What about religion? You said you read a number of Quaker books and I wondered what impression you had of how much of a Quaker she was or is--how much it really influenced her life.

Hamann: I think it influenced her a great deal. She talked of going to Meeting, and in my reading of the tag ends of her father's correspondence, and what was left of newspaper clippings from the parents' life--I could see that they were much involved in the practice of their religion. But Quakers have no formal dogma, I found reading, and Lester said, "I am so glad I was brought up a Quaker. We hated it at the time. We all hated it at the time.

"All that I remember distinctly about Meeting was that, at the end of our pew, was a woman who had a stomach disturbance. There would be sound effects--the one sitting next to her would giggle, and each of the eight children would pass the nudge and the giggle down the line. When it reached Mother, she was very cross and then we were still." [Laughter]

But there was much more than the remembrance of the woman with the stomach disturbance that stayed with her, because reading Quaker books, I found that many things that Lester had not labeled as "this is a Quaker belief" were her most cherished. They, as I said, value the free, fresh currents of life. And the invisible realities and cultivation of the eye that sees the invisible.

In the decade of her eighties--the early nineties--over and over, every time that I was there, Lester would say, "The invisible becomes more important with age. With bum eyes, and not being able to read, the invisible assumes greater value all the time to me."

She was in touch with Quaker friends--I'm sure she never went to Meeting regularly at all--but she was sympathetic and subscribed to Quaker publications.

When we were trying to find volunteer work slots for a boy who needed to be taken from his parents at high school age, she was interested enough to rummage and find some Quaker addresses of volunteer programs--so I knew she was still on the mailing list. And, of course, Westtown was a Quaker school. Ackworth, where the older children went, in England, was Quaker. Haverford, of course, is Quaker.

Her life in the East was in New Jersey, Pennsylvania, and it's all Quaker country. With both parents being Quakers, I think her 
Hamann: respect for growth as the force of life, a great love of solitude, I think came a good deal from the Quaker Meetings, the mystical shared communion. So the need for silence and solitude, I think, was given an impetus from those long, unwelcome sittings at the Meetings. [Chuckles]

Levenson: You say that much of Lester's writing to you in recent years has been mystical. I wonder how it was that so many of these people up and down the California coast road came to know about Lester and came to see her and whether they saw her as some sort of guru?

Hamann: Oh yes, yes. There was an aura about her that inspired other people. It was the same with our daughter, though she lived so short a while. People wrote to us. In the 1500 letters we received around the world at her death, nearly every one of them mentioned light or radiance. She and Lester both had that quality.

There was an awareness of life, and a zest in living-an awareness of other people; she made everyone feel good. I think that people could be with Lester, and some of her enthusiasm would soak into them. Witt her not having a great deal of money, her obvious enjoyment in living would be an example to them that without their attaining the goals that advertising dangles in front of us, life could be meaningful.

Lester never had to ask, what is life? Why are we here? She knew. People who have that certainty and are part of the fresh, free currents of life--growth--inspire other people because it's basic and sure. Yes, I've often referred to her as the patron saint of botany [chuckles] because there's awe in people's voices when they mention her.

Mai Arbegast--you've probably talked to her--she's the closest in the Horticultural Society to Lester--a Chinese lady--

Levenson: I've heard much about her.

Hamann: --in Berkeley. A fine person. She describes Lester as a "still, felt presence." It's that presence that people want to draw near to.

Lester's "Feminism"

Levenson: Did you ever talk with Lester about--women's 1ib, of course, is something of an anachronism in talking about Lester's career--but about her views on being a woman doing what she was doing? 
Hamann: She was very conscious of being the first woman in many spots, and part of her kinship with little Edith [Van Allen Murphey] was that she had the bravado to wear pants. She told me just a couple of years ago she was the first woman that she knew of in the East to wear pants, when she was developing that great garden, the Rowans, in Oradell, New Jersey, which we visited for reference.

She was working behind her great stone wall one day. A man delivered a package from Macy's, and when he went back to his driver, shutting the gate, he forgot she was in earshot and said, [whispering] "Did you know there's a woman in there wearing pants!" [Laughter] She took great pride in that.

They used to call her the running bride because she would run down the hill with her husband, racing for the commute train into the city--into New York every day from Oradell--and then run back up the hill. So, she loved thumbing her nose at convention.

When I told her I swam in Lake Tenaya at night, in early November when there was ice around the rim in the moming, she said, "Nude, I hope" because she took great pride in going naked. She felt that the human body deserved respect. She loved collecting in the nude in areas where she knew there would be no one about.

She was a feminist at heart [chuckles]. Interestingly, the Feminist Press of part of New York State University Press is interested in "Runaway."

Levenson: I really hope it does get published. It would be wonderful.

Hamann: It, I think, portrays her individuality. There will be many more erudite, more professional records of her life. But it will be hard from the standpoint of her values and motives to have a closer record than what she gave to me.

Levenson: We're very fortunate to have had you as a reporter.

Hamann: I'm very, very enriched by it.

\section{A Very Deep Experience}

Levenson: You wanted to add something more.

Hamann: When Lester was eighty-seven, she had decided that it was time to go. She'd always felt that her mind could control her body. 
Hamann: When she was ready to die, she just wouldn't eat and she'd die. She wrote finally, "I seem to have trained my body to be stronger than my mind and so it's not up to me to make the decision."

At the time of our daughter's murder, when she was so understanding, she wrote and said, "I want you to come to me. I had a very deep experience when I was having perhaps a little strokelet and felt I was near death myself. I felt so close to your daughter. I don't want to write it. I want you to come."

So we went with Lois Robinson and sat in the garden which, then, had thousands of freesias, and birds were singing. I played my shepherd's pipe. Lester was out on her sleeping bag in the February sun--in 1967--and she said, "While I was in this dream state, I thought I was going to be able to come to the end and find what was ahead. I was walking through a wood--hurrying--and felt that the new life was just before me. Suddenly there was a great light and I could hear water. I knew your daughter lived by the water. I ran ahead, thinking I could join the group that I could see in the distance, and I could see it was your daughter with her blonde hair and some of her little children friends. And I hurried and wanted to come to them. It was as if a hand pushed me back and a voice said, 'Not yet. Not yet.' And I couldn't go on. But I wanted you to know [she said] what a beautiful dream I had."

There was such warmth, understanding, compassion in her. 
INTERVIEW NOTE

Jo Stallard: "She Was So Good"

Jo Stallard lives up to the advertisement she placed in The Monterey Herald where she described herself as a "Happy Middle-Aged Lady." I talked to her on October 19, 1978, in her comfortable cottage in Pacific Grove. The arrangement of the house was as open as Jo's approach to the subjects I asked her about; teas, vitamins, and other supplies neatly ranged on open shelves, kitchen merging into study into living room, dog and cat as neatly at home as the interviewer soon felt.

Jo had stayed with Lester a number of times since 1973 whenever Cedric and Harriette went away. As Jo describes it, it was a glorious arrangement, Lester teaching Jo about wild flowers and Jo walking the Hill, bringing in wild flowers, news of conservation issues and fights, describing the behavior of hawks and kestrels above Lester's hill. Both enjoyed the vegetarian feasts Jo made, always with "lots of butter" and the marathon orgies of reading aloud, sometimes till Jo's voice gave out. Jo brings out how Lester loved to laugh uproariously or giggle her head off ( .296 ) and provides a good balance to the somewhat sober and reverential tone of some of the other depictions of Lester in this volume.

The transcript was edited for continuity, and Jo returned it promptly with a few additions and corrections. The manuscript was then final typed, proofed and indexed. 
"SHE WAS SO GOOD"

Jo Stallard

Jo's Ad: "Happy Middle-Aged Lady. .."

Levenson: How long have you known Lester?

Stallard: I don't remember there being a "first" time I heard of Lester. Seems she was someone I just knew of always. I remember though, when $I$ was in New Mexico living in a very primitive manner, a friend sent a whole newspaper page of pictures and write-up of Lester. It could have been her ninetieth birthday, I don't remember. But I was most impressed by her attitude and the things she said. I tacked the page to my kitchen door, where I tacked things I liked to see often, and there it stayed the four years I was there. Never thought I'd ever really know her.

Then, when I came back to the Monterey area in 173 and I put an ad in the paper saying that there was a happy middle-aged lady who would like a job taking care of animals, plants, houses or whatever. And Harriette [Rowntree] called and said that I sounded like exactly the sort of person they were looking for to keep Lester company, and told me about Lester and invited me down to meet them and her--and so I went.

of course, they're just family--there isn't any getting acquainted--and I fell madly in love with the whole family immediately. So, I spent the whole day practically, in talking and laughing. Then they suggested that that very evening, I think, that they'd go out for dinner and I could stay and eat with Lester and fix dinner and everything.

So Lester and I, both being vegetarians--at least, she claims to be--why, that was no problem and we hit it off great right from the beginning.

Cedric was working out of town a lot then and Harriette likes to go with him, naturally, and so I spent a lot of time down there for the next two years whenever they'd be away-anywhere from overnight to a month. I just absolutely loved the whole thing-Lester, and the place, and it was so peaceful and quiet. 
Stallard: I would never--I don't think--have just put an ad in the paper to stay with an old lady because I've known so many that were so cantankerous and impossible that I wouldn't do that! [Laughter] But Lester wasn't like that--it wasn't like taking care of an old lady--it was like being with a delightful person and friend and something that I really looked forward to.

Never once--in all the time that I've known her--was she ever snappy or bitchy or cantankerous or unpleasant in any fashion. This is hard to believe! Because I'm not that nice. I don't expect anyone to be--over a long haul. You can be nice for a day or so, but--

Anything I ever did for her, she always thanked me, always said please--did I mind doing this? She practically never asked me to do anything to begin with. But if $I$ would volunteer or offer, she would thank me.

[Telephone interruption. Tape resumes.]

Levenson: What was your background before?

Stallard: I'm still trying to decide what I'm going to be when I grow up, I guess, because I sure don't know! I'm interested in too many things--I never have been able to narrow it down long enough to become anything! And so--

Levenson: I would say it's quite an accomplishment to have become a happy middle-aged lady!

Stallard: Well, it wasn't hard at all. I just have refused to do any nine to five job indoors, practically all my life. So I end up being the oldest handyman--handylady--[laughter] in the universe, probably, because that's what I've done.

In the olden days in Carmel, when rich people owned second homes in Pebble Beach, Carmel, and the Highlands area--I think at one point, I had 250 keys--

[Slight interruption by barking dog]

Stallard: --so I would look in on homes and see that they were all right. Then, before the people were coming down, I would air them out.

I had the use of all these houses, too, and that was pretty fabulous. And the people were all wonderful. They might come once or twice a year for a few days. Then I would get a small fee from each of those, and this was great. 
Stallard: I don't care how hard I have to work--if it's not full time. What I like better than anything is to work my ass off for a certain number of days or weeks and then be off free so that I can do something--although all the things $I$ do are interesting. Right now, I mainly garden--I garden for people. Occasionally other things come up like, well this one lady that I garden for--she lives in San Francisco but has a home in Carmel, and that's where I garden. She still has her car although she doesn't drive--she gets friends or relatives to drive her down to spend some time in Carmel and then gets someone to drive her around while she's here, and then gets somebody to drive her home. So I drive her home and spend the night, and we have a marvelous time. Then she flies me back down here.

There are all kinds of things like that. Taking old ladies around--you can do this till you're blue in the face, and that gets to be sort of a bore. Although they're all nice but--I'11 do anything if it's outdoors and I don't have to do it all the time. [Laughter] And I can take my dog. Mostly I take Hap everywhere-that's important.

Lester at 93, Perfectly Self-Sufficient

Levenson: What sorts of things did you do for Lester?

Stallard: When I first went, she needed nothing--in fact, she never did need anything--she was perfectly self-sufficient. She would get up around eleven, twelve o'clock--I wasn't tied down there during the day, so I would come in town and do--I'd do gardening and various strange things for people.

I would get up and come in town--leave her her breakfast. She always liked custard and a thermos of tea and some fruit of some sort. So I would leave this for her, or she could get it for herself. Then she would get up and by the time I came back-two or three o'clock in the afternoon as a rule--she would be up, have had her bath--get herself in and out of the tub--and would be dressed and very eager to hear the news.

She's so tiny, you know, you can't think of her as being so full of stubbornness and independence as she was, and capable of doing as much. She still is--boy, she puts her mind to something-she's very strong-willed or she wouldn't have been able to physically still do the things she did. 
Stallard: I'd see her get out of the bathtub all alone. This is hard for me to believe! She never needed any help.

And oh! One request she would make of me--quite often, if I was there when she was taking her bath, she would call down, "Are you there, Jo?" I'd say, "Yes." She would say, "Would you please come and pour cold water on me?" The first time, I couldn't believe it--and I'd say, "What!?" And she'd say, "Just run some cold water"--she would be standing in the tub, you see--"and pour it over me."

I'd say, "Lester, my gosh, you'll catch cold!" "Oh no, it's good for you--it hardens you off, you know." [Laughter] So I would laugh uproariously and fill a great bucket or container with cold water--and just pour it from head right down--and she would [making shuddering sound] gasp--"That's good! That's good! That's good!" she'd say.

Then she would step out of the tub and rub herself. I got used to doing it because she said, "Oh, it hardens you off! It's good for you." [Chuckles]

Levenson: Like a seedling.

Stallard: Yes, like a seedling. She knew just how to do it. And who am $I$ to say, "No." She's the one that's in her nineties--and I'm not in that good shape at fifty-seven! Gosh!

She has very liberal ideas about everything, you know. She sees absolutely no reason why she shouldn't run around stark naked as a jay bird down there if she feels like it.

When she was more active than she is now, she would--on nice warm days--I would go down in the afternoon and find her stretched out on a deck there--in the altogether [chuckles]--which tickled the heck out of me.

I would say, "Lester, you're going to get sunburned," and she would say, "You just want me to put some clothes on." And I would say, "Well, that might not be a bad idea, you know. Someone might come."

And she says, "I'm not ashamed of my body. I was not raised to be ashamed of my body. I think this is perfectly natural. This is the natural way to be." Then she would get quite feisty and defensive about how this was all right.

The only feistiness I ever saw in her--directed toward me-was if I would suggest that she might put some clothes on! Her 
Stallard: feistiness would certainly come out and descend on me in full force--and I would be told that I shouldn't be a prude. [Laughter]

I would say, "Well, Cedric wouldn't like that." And she would say, "Cedric was not brought up to be a prude either. He was not raised to be ashamed of his body."

"And Remember, Lots of Butter"

Stallard: Then I'd fix her dinner--and I'd usually fix just vegetables-she loves fresh tomatoes sliced. I'd try to have those with corn on the cob. Wow! And mushrooms!

I would try to buy the things that she really liked--why not? I maybe spoiled her in that sense. We never had meat when I was there--but I'd make souffles--all different kinds of souffles.

She wouldn't eat eggs per se--sometimes I could get a hardboiled one down--but I would sneak eggs in the souffles, custards and things like that. And occasionally, she would eat a hardboiled one.

Cheeses she liked. But with everything she would always say, "And remember, lots of butter." [Laughter] She used to love butter--so she always had lots of butter.

When I would go, the first thing I would say, "Lester, are you ready for your tea?" "Oh, yes, that's a marvelous idea!"-like no one had ever thought of it before. Then she would say, "And could we have a little bit of toast? Very thin and very crisp, with lots of butter!" [Laughter]

Levenson: I wonder what the doctors would say about all that cholesterol?

Stallard: Well, I don't know, but it's certainly done her a marvelous world of good.

Then she liked her jello for dessert--and cookies--and she loved for me to make homemade cookies. She didn't like storeboughten bread or cookies. She wanted everything home baked. She says, "It's much healthier for you."

So I would make oatmeal cookies--she liked those--and bread. Then she'd go to bed after dinner fairly early. Sometimes she would say, "Could we read a little while?" and other times she would say, "Well, I think I'1l go to bed now." 
Stallard: But do you know what that woman would do? She'd go upstairs-and I'd wash dishes and clean up the kitchen and I'd be poking around--and there's a light still on! I'd go up and she'd be sitting up there, putting up her hair!--which would take her an hour.

Levenson: Oh, my!

Stallard: And until this last sick spell--I don't know about since then-I haven't been up there, practically any, to stay. But until then, she was putting up her hair at night--which was an enormous job--for anybody, in my opinion--but for her, she would sit there with a little tin of bobby pins and, gosh!

I would say, "My God, Lester, you still working on your hair?" She'd say, "Oh yes, Cedric likes me to look nice."

Levenson: Isn't that touching, really?

Stallard: Then she would toodle off to bed and then--Oh! I would put a glass of fruit juice and make sure her tin of cookies was always there with a glass of fruit juice by her bed. Sometimes she would take some extra jello up with her.

She'd say, "I wake up in the night and I'm hungry and I like to have a little something." So I always made sure she had something up there for the night and would turn on her electric blanket and turn her bed down for her. Then she always said goodnight and always said, "Thank you very much for staying here-I'm so glad you're here."

I would pat her and kiss her on the cheek and that'd be the end, then, till the next day. She was so good--she was just like an adorable little person--she never was any trouble--she never, like I say, was cantankerous or nasty--never sarcastic.

I can't think of a more enjoyable job--if that's what you could call that--living down there was certainly no job.

Occasionally, I would cut her finger nails, and once or twice I trimmed her hair. She said she would rather I did it--so that wasn't a very big job to do! [Laughter]

I have friends in the Sierra Club here that told about meeting her way to hell and gone up in the High Sierras. Here she was, trudging along with this enormous pack that had nothing in it but the plant presses--and no food! She was apparently very nonchalant about this and so they stopped and visited with her and she had lunch with them, and she ate so ravenously, they said, "Do you have any food?" 
Stallard: And she said, oh no, she was out. So they gave her all the food that they had left and went trudging out hungry themselves. She remembered it when I asked her about it. She said, "Oh, I remember that! I got to stay out two more weeks!" [Laughter]

Levenson: Oh!

Stallard: She was fantastic! But they say, "You can't believe this tiny little lady way up there. She was filthy dirty and happy as a lark and weighted down with all these seed things--and no food-no concern." She says, "Oh, you don't have to worry--things always work out."

When I would say, "What did you take, Lester? What kind of food would you take in those days?" They didn't have freeze dried, you know. She says [in a clipped tone of voice] "Oh, just carrots and chocolate. That's all you need--you can live perfectly well on carrots and chocolate." [Laughter] I don't know what nutritionists would say about that. And I don't know if that's really what she lived on, but she claims she did.

Levenson: Well, she took more than that, to judge by her packing lists, which are in the [California Academy of Sciences] archive. She was pretty sensible, I think.*

Stallard: I love it, though, for her to say, "carrots and chocolate." That's all she tells me now [laughter]--it's wild!

\section{Tastes in Literature and Music}

Stallard: The first thing she would ask when we ran out of immediate conversation would be, "Now, let's see, what were we reading?"-whether we were reading anything or not, she would always hopefully put this out, like a little child with a wistful look in her eyes--like "Please read to me." She loved that better than anything.

She liked best anything about plants--Fremontia, of course, I had to read to her. She was very patient about my mispronunciation of Latin words and she was very good at telling me how, so gradually I got so I could pronounce Latin a little bit better --but she just ate that sort of thing up. Then she would say,

*See Campbell interview, page 13a. 
Stallard: "Oh yes, yes, I remember it now! I know where that is. I was there."

Then she would tell me side stories about it or else she would say, "Repeat that--now what was that again? Oh, well, isn't that interesting?" She was right in to whatever it was I was reading. Sometimes she'd like me to re-read things like that.

If we didn't have anything on plants, then her next favorite was anything of nature--animals in particular--she loved all kinds of animals and I could read her children's stories or--we have exactly the same tastes in everything--

Levenson: How marvellous!

Stallard: --so it was the most heavenly thing because I would read her the things that $I$ was interested in. I became more interested in plants as a result of knowing her and now go to a lot of the native plant things here locally, and I'm taking a big long course in the natural history of the Monterey Peninsula and Pt. Lobos--which I probably wouldn't have done if I hadn't met Lester.

She has a way of making you--I think--enthusiastic and interested in those things because she was so interested and you figured, "Man! There must be something there!"--because we were interested in everything else the same--and I figured if she's interested in plants, then let's go for plants! I've missed something.

She was always considerate though. She wanted me to read and I think if I read twenty-four hours straight, she would have been delighted. But she would always say, "Now, don't read until you're too tired--don't tire your voice--you stop when you're ready." If I could--and if I didn't have to do anything else, I would read until my voice just gave out.

Then she would feel bad--she would say, "Now, you shouldn't have read that long." But I would be interested and so would she.

Let's see, she liked anything the Indians would do or say. I think probably when she was out in the mountains--in the wilderness--liked to think of herself as an Indian--she certainly seems to have lived like one. [Laughter]

Then she loved to hear music sometimes--when I would be fixing dinner--or when my voice gave out--I would say, "Would you like to hear some music?" And she would say, "Oh, that would 
Stallard: be nice." Then I'd plough through the records and pick out things--no piano--she didn't like piano--except she tried to encourage me to go down and play Harriette's.

I would say, "But you don't like a piano, Lester." She said, "Oh, that's different--that's all right if you go down and play."

Levenson: What were her favorite pieces?

Stallard: I don't know if they were her favorites or mine, but she seemed to request anything of $\mathrm{Bach}$ or Mozart or Vivaldi. [Pauses] Occasionally if I would put on Beethoven--some of the things were okay--but some of them she'd say, "That's enough of that." [Laughter] She didn't care too much for that.

There were records of bird songs, too--and sounds of the woods. She loved listening to them.

No Use for Tapes for the Blind

Stallard: But--I never could get her to listen to the tapes for the blind when they started getting those--there was just no way that she wanted any part of that--although there would be someone reading a story that maybe she would love for me to read.

When I'd try to tell her, "You know, this is on tape and I think you'd enjoy it," she'd say, "No, I don't think so--not now." She wouldn't be impolite about it, but the "not now" was forever-and the time never came.

Yet, I thought, "Now I'm going to fox her. She loves for me to read things to her, and I found this book--Touch the Earth-quotations from Indian leaders of the past--the things they have said--they were the most beautiful things, and I thought, "Oh! This is for Lester but it's something that she would enjoy hearing over and over."

So I taped it. I said on the tape, "Hello, Lester, this is Jo and this is for you to hear sometimes when I'm not there to read to you." And I read these things. Well, she loved that! --and she would comment all during the time. But she loved for me to play it even when I was there!

If I was busy she'd say, "Put on your tape." I think she liked the personal touch [laughter]--she liked to think--she felt that was something special for her, maybe, which it was. 
Lester's Need to be in Touch with The Hill

Sta1lard: Lester liked it when I'd say, "We1l, I want to take the dogs for a walk now." See, Hap [Jo Stallard's dog, Happy] always went down there with me. And she would say, "Oh yes, that's very important--that's very important that the dogs get their exercise --oh, do, do--take them for a nice, long walk."

She would be willing for me to stop reading if I were going to take the dogs for a walk. So I did that every day when I was there--so they got a nice walk.

When we would go to the Rowntrees, my dog would rush in and jump up on her and kiss her all over--like she does everyone--and she would be so pleased--Lester would be--she would say, "Blue likes it here, doesn't she?"

Now the first time she saw my dog, she said, "Your dog's blue!" And I said, "Perhaps in the way the light's shining on her, she does look blue," although she's gray and you could see that it's blue--she said, "Well, she's blue to me! And I don't care what her name is, she's Blue." And from that time on, she called her Blue. And this crazy dog answered to it.

She would go to her when she called her Blue. If I call her Blue, she doesn't pay any attention--her name's Happy. But to Lester she was Blue and Lester never forgot that.

One of the reasons she 1iked, I think, so well for me to walk the dogs up on that mountain was that she would say, "What flowers are blooming? Now bring me one of each back." And she'd say, "Now be careful, don't take too much, but where they're thick, you just bring one back so that I can see them."

And oh, gosh! One spring, two years ago, [Lester was ninety-seven] the flowers were so thick and I walked all day-way, way back over a couple of ranges and came back with dozens and dozens and dozens--a whole big thing full which were all wilted by the time I got home--so were the dogs! I had to carry mine home. [Laughter] I had to carry Tessie home once, too.

Anyway, we got them back and got her big magnifying glass out, and she was all excited. I spread them out on the coffee table and she started looking at these, and by damn!--she could name every one of them--the common name, Latin name--and said, "Where did you find it?" We11, some of them I could remember and some of them I didn't know. 
Stallard: It was like seeing old friends! I think that was the greatest thing in the world. You know what I wanted to do--doggone it-she wanted to go up on that mountain that spring so bad--the flowers were so beautiful.

There is, you know, that fire road up there and I thought there must be somebody that had a jeep so we could get her up there. When Cedric came home I asked him--I said, "I' 11 go! I'11 take her up!" Just to get her up there and sit her down in the middle of these flowers and let her feel them and smell the smells and just what it's like up on her mountain. I said, "I'll be glad to!"

And he said, "Well yes, we do know people who have a jeep. I'1I see--we'11 do it." But they never did--it makes me feel bad because there's no need in protecting anyone when they're that age--and something that means that much--I still think they should do it--even if they had to take her up on a stretcher now! [Chuckles]

But that's what she would like--because around the house there, anymore, she says, "This isn't the garden. There isn't anything here anymore." But she still loves it up there.

I know when she could still get out on the deck, she would say, "What does the Hill look like?"--so she really couldn't see it anymore. I would describe it to her and she could hear the birds--and she would say, "There's a flicker," or "There's a thrasher."

Once I was watching a kestrel eating a lizard way, way up-with binoculars--I'd tell her about that. She loved for me to describe all the things that were going on, and the hawks. Of course, I'm a hawk lover--I like the birds of prey very much-I'm always watching for those.

She felt such a closeness to that hill and the things that went on--the wild life and the plants and things--and she liked to keep in touch with people telling her things about it.

The Need for a Sense of Engagement: "What Can We Do?"

Stallard: I don't think they told her anything that was going on in the community or in the state or in the nation--about conservation things and things that she was interested in, from her attitude when I would talk to her about things. She seemed to be totally 
Stallard: unaware of any of those things and very eager to know--which leads me to believe that no one bothered to teil her what was going on anymore.

I think that they did it so that she wouldn't be upset and worry, but gee whiz, this is what the future means. She needed something to think about and get concerned about and to do--I don't think it's a worry thing as much as a happy, constructive type mentalization--especially for someone who has been concerned all of her life.

Levenson: Keeping a sense of engagement, I think.

Stallard: Right! Just in the world--part of it yet. Like she would say, "What can we do? This is important." And whether she actually did anything or not, the impetus to do something and be involved and to help--it never died! Never!

To this day if I go down and will talk to her about something that I'm doing--some conservation project--she will say, "Good-good--that is good! My, that needs to be done! I'm so glad that you're into these things. I'm so glad. We need people to do these things."

I've got more pats on the back from her for things that I do--and encouragement. So I'm sorry that she hasn't been kept more informed.

Every time I went she was all excited. "Now tell me, what have you been doing and what's going on out in the world, and tell me all about it." She would love that, especially things pertaining to wilderness or any natural area--she was very concerned about Elkhorn Slough.

The local Audubon Society has given The Nature Conservancy a lot of money to buy up land there, and now it's going to be a federal preserve. This she would be interested in.

If there were meetings--"Now you go to the meeting--now you fight for this." And, "What can we do?" she was always saying if there was some terrible thing happening in the area. She would say, "What can we do? Shall we write letters? Let's write letters--that always helps." Or, "Do they need money?" and, "How much money do you suppose would be helpful?"

On occasion we'd write letters, but sometimes she'd forget, or else she would say, "We11, we'll do it later," and she would get tired it seemed, and forget. 
Stallard: She wanted to do things, but when it came right down to doing something physical like that, I think she was afraid of her handwriting--that it was too shaky or she wouldn't be able to do it properly.

Lester's Reputation in the Monterey Area

Levenson: When you mention Lester Rowntree in the Monterey area, how do people respond?

Stallard: Great awe--tremendous awe--like when people find out that I would be going down there--I would say, "Well, I can't do that," or "I have to hurry--I have to go down and stay with Lester"--and it's, "You mean Lester Rowntree?" Some of them would say, "Is she still alive?" I'd say, "Yes." [Intake of breath] "Isn't she marvelous? or "She's been the most wonderful--," "I remember her," and then, you know, the story. A lot of them, of course, stili know her. Then they would say, "We've been wanting to go down to visit, but we haven't known whether we should or not. Would it be all right?"

Then I would tell them what time to come and then they could come and visit and have tea with her--which she enjoys. She's sort of shy when people would come like that and I would say, "Somebody's going to be here around two o'clock and have tea with us--an old friend of yours." She would say, "But my hands shake. They might not want to be with me."

I would say, "No one minds that. They don't shake that bad." She would be very nervous until they came and started to talk, and then it would be all right. But she's very shy--shy about her appearance and about, "We11, I look old." I just kept reassuring her that she was just fine--she looked just fine.

I would say, "Now, this shirt looks nice. You look nice in this, Lester."

Once they were there--some people she didn't care for--that's true--and she would be just very quiet when they were there. I never heard her be rude to anyone. And no one would notice-except I saw her with different people--and some people she would rattle on and on and on and talk very animated and free with, and others, she would just be very quiet and would only answer direct questions. 
Stallard: Then when they would leave, she would say, "I don't really care for that person." I would say, I could tell by your action!" She says, "Oh, well, I didn't seem rude, did I?" And I would say, "No, but I can tell." Then she would laugh and say, "We11, I didn't mean to be rude." She said, "I just don't feel that I have anything to say."

I have the minutes of the [Monterey] Audubon Society from its inception--I think May in 1941--and I've had a lot of fun going back and reading the things. I have it here. I found them the other evening--I've been going through these for Audubon's benefit and I thought, "Now, isn't this a kick?"

Here Lester talked to the group--[musingly] is it this March one? [Reading from large black and red ledger the section for March 13, 1943] "Mr. Laidlow Williams announced that

Mrs. Lester Rowntree would show lantern slides" [aside]--isn't that marvelous?--"on wild flowers at two p.m. at the Pacific Grove Museum on April 10th."

And so, then, on the next one it says after their meeting things in the April 10th. minutes, "Mr. Laidlow Williams, program chairman, introduced Mrs. Lester Rowntree, who showed colored lantern slides of wild flowers in Mexico and California.

Mrs. Rowntree then conducted a tour around the grounds of the museum where native shrubs and trees, as well as wild flowers, have been planted."

Now I was wondering, too--I haven't asked Verne Yeadon, the director of the museum, who did that garden around there. But I sort of have the feeling that lester did that garden.

Levenson: I don't know. It would be interesting to find out.

Stallard: I can call him and ask--I'm sure he'd know.*

*I talked to Vern Yadon, of the Pacific Grove Museum, and he said that Lester had nothing to do with the Native Garden there. But she always took a very active part in the annual wild flower show which they have at the museum each spring. He says laughing, "She always got on me for having flowers in the show which were not natives." Vern said she stopped the developers one day at Yankee Point when they were just contemplating the development, and shook her finger under their noses and said, "If you ruin one bit of this place I'll come back here with a gun!"--J.S. 
Stallard: Anyway, I thought that was fun--lantern slides.

Views on Women's Lib

Levenson: Did she ever talk about Women's Liberation with you?

Stallard: Yes, I've told her--I've gone and talked to her about this Women's Lib thing and she was very disdainful about it all. She said, "This is utter nonsense. I've been able to do anything I've wanted all of my life without any legislation. I think if women want to do anything, they can." And that was that. She said it was a lot of fuss for nothing.

She thinks women ought to do anything in the world they want to do, but she sees absolutely no reason why they can't! Period. Why are they making a fuss about it? Just go out and do it.

I would try and explain, "Well, you know, it's the money more than other things. They don't get the same pay for the same job," and things like that.

"Well, they certainly should. There ought to be something done about that," she would say--"Why, just don't do that if they won't pay you the same salary."

But she didn't really have much sympathy about that at a11. She didn't see why, if she could do those things, then other people can, and I feel pretty much the same way. I've never had any problem--done what I want to do all my 1 ife. I can't see going out and making such a fuss about it.

She had strong feelings about being independent--and I don't know if it had as much to do about a woman as being a person. That people ought to be able to do what they wanted--and if they were capable of doing this, then they should have the freedom to do it.

I guess this was the problem with her husband--he saw things different. I can imagine her standing right up--that feisty little thing and saying, "I'm going to do what $I^{\prime} m$ going to do, and if you don't like it, that's too bad--this is the parting of the way."

I don't know what happened--I haven't the vaguest idea. But knowing what she's like, I can imagine her standing up. From what she told me of her family, though, and things, she seemed to 
Stallard: resent the fact that her brothers thought that since she was the girl, she ought to get married to somebody that would take in father, and then she'd be sort of stuck with that responsibility. She seemed resentful of that.

Although apparently she did that--she did stay--so at what point she revolted, I don't know, but I would say whatever point it was, it was probably high time.

But as a whole, I can't imagine Lester being too nasty or too mean about anything. People, when they get old--their attitudes seem to deteriorate, I find, rather than get better. There's too much politeness and too much gentleness and consideration in her yet to have been too much different ever--I would think.

Dilemmas of Old Age

Levenson: From these particular comments on some of Lester's dilemmas as she's grown so ancient--ninety-nine is ancient, I think. Do you feel that there are any generalizations that you can make about the problems of aging?

Stallard: People get worse as they get old--not better--very seldom have I heard of any turning angels as they got old and incapacitated. This is the time when you really get mean and ornery--and for good reason.

I would have seen some of that--I think in all that time-those years--when she was getting progressively less capable-her eyes were getting worse--she was falling down more.

At first she didn't fall--she was very agile when I first went out there. Her shaking--that trembling was getting worse, and she was very concerned about that--very ashamed of it--but she never got mean and she never got moody--at least with me. And I don't think she could have held back her natural feelings for a two-month period. I just don't believe it.

Levenson: I don't either. It's a remarkable tribute.

Stallard: I've never known anyone who was easier to be with--more considerate; less demanding. I don't know if she ever asked me to do anything except pour cold water on her and once or twice to cut her fingernails and trim her hair--and with that, she was very apologetic when she would ask for those things--did I mind-did I really mind? 
Stallard: And my gosh! Her fingernails would just be--I would go down and they would be really, great huge claws--curling over--[gesturing one and a half inches long]--and it just made me pretty mad that no one would have done anything by then.

She would say, "I'm having trouble combing my hair and putting my clothes on," and so on. And her toenails would be in the same condition.

I've asked her, "Did you ever think you'd live to be this old, Lester?" And she said, "Well, I never thought about it. I just lived in sections--my life's been in sections--and I just lived a section, then another section. I never thought about getting old."

Now, of course, she wants to die--there's nothing for her to do! I don't think this is necessary for anybody to feel so useless that they want to die--when she isn't in any pain. I think she feels useless. I think she feels in the way, and I think most old people do if they aren't made to feel a real part of what's going on yet. I would feel useless. Anybody at any age feels useless if they're not a part of whatever's going on-good, bad or indifferent! If they're not involved--and she is just like in a backwater.

She's down there in that room. There's nothing to stimulate her--it goes on. Occasionally someone will go--like me or you-or perhaps a member of the family--but they're busy doing their own things--everyone's busy doing their own things and there's no own thing for her to be doing anymore.

I think it's a shame that this happened--and I don't know what you can do about it--I don't know if there's anything anybody can do about it.

If I--or somebody--could spend more time with Lester--if she could be read to--or talked to--or asked her opinion of things-for a little while every day--or even every week--it would make all the difference in the world, I think. I don't think anyone ever asks her advice or her opinion--and she has a lot of valuable knowledge. 
"Jo, when Am I Going to Die?"

Levenson: Did you ever talk about religion?

Stallard: Yes, a lot--because I'm a Buddhist and Lester seemed to profess that type of belief more than any other. As a matter of fact, Harriette brought all of her religious type of books in--for me to have.

We've converted one of my rooms back here to a sittingmeditation room, and have a library, so Lester's books have been added to it, at least for the time being.

I used to read books of that sort to her, too. And we would talk a great deal about--she had Krishnamurti's books and Allan Watts and so did I. They all say the same thing--all religions say the same thing, except some seem to appeal to some people more than another.

Lately she got very impatient about not dying. The first thing she would say--lately when I would go--would be, "Jo, when am I going to die?"

I would say things like, "Oh, for heaven's sake, Lester, you'll die when you die." Then she'd laugh and she'd say, "We11, I know that's true. There's a purpose for everything. I just don't know when this will end."

When she was in the hospital [May, 1978], the nurse was standing there. Lester had said to me something about, "Am I ever going to die?" I said, "You most certainly will--I don't know anybody that gets out of here alive!"

And Lester said, "We1l, I'm going to die!" The nurse is standing there and she says, "Not on my shift, you don't!" [Laughter] And Lester laughed and laughed. You could always get her to laugh. I loved telling her things that would make her laugh because she would just giggle her head off or else laugh uproariously. It was really worth it to me when she did because sometimes she seemed pretty uptight.

When I would come, she would say, "Oh, I'm so glad you're here!" Then she would say, "Have Cedric and Harriette gone?" and I'd say yes. Then she'd say, "How long are they going to be gone?" I would tell her and she'd say, "Why don't they tell me that?" And it upset her that they--they were afraid it would worry her, I guess--but they wouldn't tell her--and that really upset her. 
Stallard: I tried to tell them that, but--So I liked to have some funny story to tell her when I went that would start her to laugh and take her mind off of it. Then she'd always say, "Oh, I'm so glad you're here, Jo--I'm so glad you're here."

Sometimes [laughs] she seemed a little provoked when I'd go and she'd say, "How long are they going to be gone?!" And I'd say, maybe oh, two weeks, this time. She'd say [emphatically] "Good! We can get a lot of reading done!" [Laughter] And she liked to get a lot of reading done!

Levenson: Thank you so much.

Stallard: You're welcome. I hope I've helped fill in a few corners because Lester means a lot to me. She has, and she always will.

She's somebody that I'm awfully glad I knew and I don't know that there's going to be that many people I'll say that about, an awful lot of animals probably--but not too many people! [Laughter] 
APPENDIX I

Among Lester Rowntree's papers were several envelopes marked "helps." They were full of odd scraps of paper on which she had scribbled thoughts and phrases that could be useful to her when writing.

The bulk of the paper scraps precluded their being retained in her archives. However, since I have become fairly proficient in deciphering her hand-writing and since I felt that these tid-bits were very characteristic, I have copied off most of them and trust that my handwriting is easier to read than the original.

Margaret W. Campbell

November 3, 1971 


\section{LESTER ROWNTREE'S "HELPS"}

The desired commodity

It insinuates itself into the life of the rock garden.

Fundamental drama of the rock garden.

Soil-life-giving earth not filthy dirt.

On-rush of Spring

A breath of hope

Unquenchable optimism.

Disturbing-disquieting-thought

Pick the fitting plant

Only the trained observer

Leaf mold-duff

To tone up the whole

knotty nomenclature

Make it your business to

Which I hold in fond remembrance

By the same token

Fraught with danger

Mr. Farrer's imposing repositories of rock garden lore

Nothing baffling about--

Suavely furnished

When you fashion your rock garden

If you feel impelled--

It uses its leaves as a barometer of health

For not entirely inscrutable reasons.

Hard-hitting-ringing phrases

As rock garden construction gets under way.

With emphasis on well (ill) bred

This enterprises a grim picture

Keep in mind the shape of things to come.

And that is the end of it which seems a pity for it could have been prevented Pièce de resistance

Used like this they can become one of life's gaieties.

May become a perplexity

Encomiums fail me

Trouble--that with the fussy garden when forced to? One can't leave it to the maintenance man but must find a more deserving soul to administer to 1 ts needs. Place the denizens

Install the occupants

To no good purpose

Brings a fillup to the rock garden

Makes much blather over poor drainage

Strutting plant

Go to some pains to--take pains to

Stirs the rock garden

Scintillating 
Don't use dry bread when you can get caviar

Caviar where there might be dry bread.

Give new answers to old questions.

Both natives and outlanders

If I hadn't used up my new (?) adjective on--I would call on it to help me sing the praises of--

Insufferably banal

Nullity--to make of no value

If it has a temporary aberration give the vitalizing benefit of--

The habiliment (dress attire) of the rock garden

Evil-dispiriting-painfull

[Mugwumpery] mug-wumpery

Is a crusty character

An artful hand

The disturbing thought

Abetted by--

Make concessions to--

When you go out in the morning to see what your plants are up to--

Result of your handiwork

It was many many years ago I first warmed up to--

Compelling

Life and warmth

Dwell on the excellence rather than the shortcomings

Which I shall explain in due course.

And let the flashlights shed their beams

The jig is up

Baleful

Lethal effect

Collection--or arrangement of words

Resplendent

It wilts before your eyes

Divertissement

Acquiring merit

If you and your rock garden are geared--

Leaving the gardener considerably shaken

This will goad you on to--

With sickening effect

Then while the elation is still with you cement some of it into your plan for the garden and home

Plants which serve the rock garden

A spirited plant

And such untoward doings

Baffling

Citizens of the trade--or citizens of the rock garden

Case history

Those who make moan

They (mts.) regard each other coldly

Anyone with horticultural leanings

Defeatist 
In spite of drought, wind, cold, heat--all of them--this plant takes its rollicking gait.

Do you remember when the horticultural world got all hot and worrfed.

For a garden bumptious with marigolds--

Some time ago there was much tongue wagging and more words put down.

Gophers travel through my garden gathering my precious plants to their father long before their time and leaving their bodies lifeless and--where but yesterday they gleefully adorned the garden.

Contumely

For which I should be wearing sack-cloth and ashes

I once planted--and should still be wearing sack cloth for the foul deed but-Was a surcease from (grief)

Doldrums

Was a little more than I could bear so--

That is uncontrovertable--indisputable

The old reprobate

Is a good plant and may his years be full and fruitful.

I once said that! Well! Now I rise to say that--

Those triumphant sounds you hear from the West Coast are from the baying mouths of hybriders who have--

One never knows just how good an idea is until it has appeared in [print] public. In the mind of its originator it may appear a brilliant star but when thrown to meet the reader's eye it becomes drab and bereft of sparkle. A terrible column name but nothing can be done about it

Take that as a storm warning.

According to the ordinary gardener's measuring rod.

I write feelingly about this having just--

Gardening--the most democratic--most aristocratic craft in the world

[Sat. Ev. Post.]

And don't forget the charm of bare bark and the beauty of curved and bending bow

Hungarian legend! If a listener sneezes during telling of a tale then the story is true.

It is my considered opinion

Ebullience of--

You may think me "touched"

Enough to try the temper (patience) of the most casual (even-tempered) gardener Connotation of delightful charm.

Antic plant--blithe spirit

Or it will soon be numbered among the missing.

It is a companionable plant willing to stand through thick and thin.

With a sure touch

A significant plant

Noble plant

In 1 ts sun-drenched place

If--baffles you see what (moving it, cutting down, withholding water) will do. --Is a cut (several cuts) above the other

If destiny should turn you into a--fan.

Invokes enthusiasm 
Analogy

Rock gardens: Pursuit of happiness

A practical type

A nifty little piece

A gauche plant

The horticultural practitioner

Its--is profound and at times almost ribald.

Past praying for

Nursery box of sand--a plunge-bed.

If you don't (do)--,--won't be long for this world

Belongs to the August family of--

Don't crowd your luck

Bouyant

Will lead you astray

It might go broody with zeal

--in its very fiber

This liliputian--

Get alerted on the subject

So we won't cavail at the--

Among the contretemps of rock gardening.

Mea culpa

Untrodden paths

Shocking, no end.

Militate against

It was on one of those--

Instead impelled by the strange irrational momentum of a first intention

I made an ill-advised turn

A stand of--punctuated by--

Which may be the indication of a trend.

Which is incorrect (a little strange) but nice

Penstemons being what they are--

Exemplified

Which may unhex it

This recurring problem

Traipsing

Pretty special

--is a gay little sprite

Its seed germinates with gratifying promptitude

All and Sunday

While I am properly impressed by

To such a plant I prefer to send my polite regrets rather than cultivating

its more intimate association

My affectionate allegiance

-companioned by--

If--defies your horticultural blandishments

There but for the Grace of God go I

And we raise our plaintive voices against--

That's all Tosh!

Defeat lies that way. 
If the plant could give Tongue it would doubtless speak in terms that would singe your hair off.

For the tantalizing of the faithful

Flagrantly

Put that in your file

And if you live inland it's not for the likes of me to tell you what to do for this shrub. You might try--and--but for more than this you must follow your own nose.

Not to all of us is it given

To bully and badger

If you look back over the case history of this plant

Those who dream darkly of--

In its spurious--

Low whimperings of Tiny Tim

A little pipsqueak of a man came jumping out

Impinged

Dulcet tones (notes) of the doves

--is the chief weapon with which--competes with its companions. Fire resistance is another.

An ill-natured, sulky place

Meet the situation with gaity and--

Greedy

Ambition once stirred me to--

Altogether a most enchantable exposure

They will prove heroes in (such and such a place)

Plans went a-gley

A nebulous--

No early Christian martyr suffered as I at the hands (teeth, I suppose it is) of gophers!

Lares and Penates

Blurb

Go to the wild when setting trees and shrubs

Guiding hand

In a book of this sort it is not possible to get away from actuarial details-heavy-gaited and prosy

I am in no way accountable for the difficulty of these names

Sorry, but I know of no common name for this tongue twister

By the time the garden gets to this stage--then is the time for soul-searching.

For convoluted reasons

Devotee

One day pondering the move--

As gardeners will--

Resilient

Traipsing

Is an example

Let's say--

Prone to--

P1umy

First things first 
Fitness comes first

Title: Rock Gardens for the West

Sins and pitfalls

Counsel for the novice

Galaxy

Don't sacrifice the sense of freedom and naturalness to the craving for neatness and order.

And if you must have rock garden's theme song

The right plant--the right place--let that be the motto on the rock garden shield--indeed let it be the motto of all gardeners.

Socially unfair (unfit) for the rock garden

Fey

The vagaries of quick integration

Fugitive

The gardeners taste and spirit reflected in the rock garden

For the rock plant--cum annual set-up.

Quite fetching

Polishes it off with--

You may shake your head over this but--

At--do a fandango (mazurka) with--

I am bored

Do a track meet=spreaders

It should be crystal clear

An unwholesome look

Unseat it immediately

Most provocative line of gardening

With contrary results

The mores of this group

It is, as you see, pure--that prompts these remarks

A bit of debunking is needed regarding--

Heave the brick of criticism

This brave plant

Which is--if that's the right word to describe a--

Captions moved

Atypical

Sound

They are, as the saying goes, a riot

But, as to ignore the call of duty is alien to my nature--

That effusive scent you get is--

I now come to- - - which is a --group and useful for

Pulse--the surge of--

Vibrate with--

Slacker

Neglect

Don't relook

Never disparage

Laquer--luster--sheen

Clay-colored--Ashy blonds--hoary-waxy-candlewhite

Cast in the same mold as a -- 
Contours-features-balance-

Well set-up

With fine finish to it

Rocks: big cylinders and bows, crag, stark, gritty, granite cliffs, stout, vigorous, buttress, broad shouldered, strapping, stalwart, fissures.

Thrusts, pushes, shoves, jolts

Embroidered, studded, flecked, piebald, dappled, marbled, checquered

First fine careless rapture

Regard with fondness

Rapturous, fancy, captivating, winning, intriguing, amiable, a honey, dancing, iridescent

Hope, capacity for, one of the graces of--, blissful, bright-eyed, well-favored, polluted, elfin, squat, dumpy, pebble, dapper, irresistible, fairy-like, accomodating, comely, exultant, milky, satin, silky.

Picayune

Old and new-when as a girl I was gardening with my father in California we grew many old flowers which are new today. After a wave of popularity recedes a few puddles remain where certain gardeners, finding they love a plant enough to keep it, but after it may be forgotten by the majority-25 or 50 years later seedsmen and nursery men puil it out of the bag again and it is hailed as a new plant and new it is to the beginning gardener. Many of the old ones which have been out of circulation during the war, as well as some new ones, will be in nurseries subject to call--it's up to those gardeners who realize the need for garden distinction and who buy the better plants and encourage the nursery men to grow them.

Once a wel1-planned rock garden is established and is on its own it becomes a burdenless plaything--a delight.

No monotony in a rock garden. A federation of plants made up of groups of collective plants

Some need caviar; some prefer dry bread

Chandeliers to light up the rock garden

When it is done the rock garden is not a floral chess board-like a collection of bedding plants but a permanent picture which the plants with a little help from us changes with the seasons though the framework remains the same.

Demoralize

For all that--

Proceed apace along those lines

Plant of distinction

A spiritual plant

There can be many variations to the scheme-dianthus, campanulas

Fortuitously

Commit mayhem

I write feelingly about this having just--

Defeatist

Anyone with horticultural leanings

With a significant little?

To tone up the whole

Knotty nomenclature 
A problem and a challenge is something to welcome, it brings out the ingenuity--

Rollicking, frisky, tilt, jaunty, bouyant, spry, breezy, vivacious, sparkling, sportive air, winsome, buxom, hearty, bonny, waggish, animated, gladden, animated, jovial, festive, frolicking, merry, wanton, revel, gambol, caper, romp, exultant, jubilant.

Nobleness, esteem, luster, splendor, majestic, sublimity, unrivaled, eclipse, glitter, enthrone, blazon, enshrine, notable, eminence, imposing, sublime, princely, one of the gentry

Moist Places: plashy, poachy, quaggy, squiggy ground. Blend rock gardens into wet place meeting wild garden and wet sun into wet shade.

Interpolate

The orderly procedure of nature

Keep its disposition sweet

Culture; meaty material; fare; rations; for fodder, provender, nourishment, for pasturage, larder; repast

Peevish

Maiden efforts; pristine traits; prone, touchy, but if you believe in miracles its worth a try; for restricted space; plants nobly honored and fed; an insult to the eye; to make the p.b. look its best; with cherished plants you--, with care free plants you--; impotent.

Plant is ' $S$ ' gift to the NW (S.W.) rock garden

The are blessings on the (SW) NW rock garden

's charm comes from its
and may be the natural result of

The flares forth with fine pomp and circumstance.

You will find it burgeoning with fine enthusiasm

There is not its like in all the world of alpines.

Something of a ruffian but just the thing for

A tiresome plant

Its behavior sometimes baffles

Such actions make it mutually embarrassing for person and plant

This amiable plant

Be it known that all and sundry

Horrific

A devotee of al fresco timing

But in case a rock garden happens to be your dish--

Will brighten many of your days

Boulder; rock drums; crag; cliff; promontory; highland; peck; pike; bluff;

ledge, escarpment, hummock; knoll; hillock; butte, fell; tier; notch;

gorge; chink; breach, rent, gash; fissure; Tubby, spore; heap, no

obelisks or Eiffel Towers for me or flag staffs or lighthouses; on the

beetling brow of a good high rock; mount; bestride; soar; perch; overtop;

elevate; aloft; manipulation; procedure; discharged with grace; filmy

Hearty; neighborly; intimate; cordial, candor; honesty; sincere; frank;

there are plain-speaking plants like_and artful fellows like

Ingratiating; discriminating; luxurious; idolized; bewitching; engaging/

adorable, entertaining; enchanting; attractive.

Site; settlement; cohabitation; bivouac; storehouse, cradle; lest it pitch 
its tent; ensconced; embossomed; constructive; workmanship, fabric; put together; organize; shape; form; feature; outline.

If you are the sort of person whose plant-and-earth hunches work out for good, follow them and encourage more--its corroboration is the only reason for the hunch.

In general folk of the Big Valley can clip over to the coast for a revel in the dull damp fog and fog dwellers can head eastward when sinus, catarrh and rheumatism become unbearable but because our plants must stay put in the ground the year round it behooves us to be pretty sure they are going to like the conditions before we ask them to put with us.

\section{ANOTHER GROUP OF "HELPS"}

A herbarium specimen is necessary but it is to the real plant what a mummy is to a human being.

As unlike as the voices of various members of the same radio family (on the radio)

This plant, you can readily see, is an extraordinary--

If you will do this to (plant) you will have one less worry to take with you to bed.

Then let the true gardener within you rise and--

I am sorry I can't stop on that high (?) note but honesty forces me to admit that--

Some dread disaster

With impassioned tones

A gesture prompted by hope rather than necessity.

And if you fall upon evil days

But here I sit putting penciled words down on paper

Beginning of an end: The interviewer threw a glance around taking in the hills and the sea ( $I$ hope the shadows on the hills and others on the sea) and looked at my plants.

Go out and drown your sorrows

Will shatter the calmness of your life.

Archaeological significance

Admiring in rather a nervous way

The simultaneous growth and decay of the world

Consider yourself warned

Disappear out of your life forever

Suckled on--and fattened on--

--hy present standards is--

Laughing of the wind in the trees

Will cause you acute distress

Gap between the publisher and the gardener

Publishers don't realize the number of potential readers--the middle west-south and west whose gardening possibilities are not covered by authors who write from experience limited to only--states. That is why I felt it necessary to get gardening experience in various parts of the U.S. before writing my first book. 
They assume their material is for all [the] country; if so, it should include material for that section

What I would like to see is not more (bigger and better) horticultural forms and hybrids but more species--wild flowers from other countries.

You send to foreign countries--Australia--So. Africa for the catalogues of the ordinary (??) seedsmen and you see listed the very species we have here in our home catalogues. What we want is to see included is the seeds of the native plants.

Lucky in having stout feet--crop of very nice inlaws

As I do not wish to follow the all too customary method of writing the opinions of others for the benefit of those who do not happen to have already read them, I include here only those plants which I have either studied in the field or grown in my garden. In the majority of cases I have done hoth.

Having a thin time of it.

As a protest against too free use of quotation marks and too free use of capitals--

Nothing very earth-shaking

Richardson Wright says Garden Clubs are composed of gardeners and bouquet ladies. I would like to add a third class--legislators or organizers. Before the bouquet ladies came on, there were just the two classes-the gardeners and those who organized or arranged the club committees, federations. So--few are the garden clubs today who have escaped organization and remained purely gardeners.

The case of--

Given strength you will at last be able to grow-Unsettling, to say the least. Unsettling

A flower in a minor key

With winged words

Then, heady with success, we move on to--

After which scalding remarks--

Fraught with peril

The case against

What would happen if (all the Ceanothus hybrjdize)? I've brooded a good deal about that one.

Before your behavior patterns are frozen

Will become the light of your declining years

Another plant that tweaked my fancy was--

Turn your back on your birthright

Dapper.

With a bad case of--

Expansive, stretch, scope, range, spread, sweep, "waste", wilderness,

desert floor, slab, escarpment, table land, slice,lech.

In a moment of mutual aberration

And other esoterics of gardening

In residence

Nothing soul-searing

The yearnings of the young

Shattered 
Mooching about

Such practice is frowned on

Dizzy eminence

Lines of endeavor

Droll men with charming wives

As thick as deer on Mt. Hamilton

Nothing earth-shaking

Poor relations

Radio announcer thanking people right and left

Is very good though not quite out of the top drawer

Sometimes I think that gardeners (if they must be divided into classes) fall

most easily into those who like to read about some plant they already

know and those who like to read about something new.

Feels stuffy and dusty--just as I do when I've been in the house a long while.

Make me get hot under the collar.

Which is barking up the wrong tree

Felt quite wronged.

You haven't a Chinaman's chance of growing it.

-with its look of secret sorrow

With deep inner wisdom

And don't say I didn't warn you

With clouded brow

Titles: Trend Toward Farewell to Wildflower Magic

Mexico: I cannot yet think of it without emotion

Things move more speedily these days, you go away collecting for five or six months and come home to find friends and the radio talking about an entirely new set of people and things. 
Lester Rowntree: Images of the English and American landscapes

March 1-2, 1969

(Rowan kowntree)

March 1.

RR: What do you remember about England?

The last time I visited England, Josephine (Jackson) and I got embroiled in the southern part. We were handed around from garden to nursery and we never got to the North. Although I've been back to Penrith twice since I was a child, (1907 and ), I want to see it again.

$\mathrm{RR}$ : What's the country like around Penrith?

Delightful. Penrith was a market town on the edge of the Lake District. We lived up on a hill along the road that travelled to the beacons. All the houses have names. An aunt and uncle had a house they considered to be their last; named it "Alabama."

RR: (note: At this point, Lester searched for a color postcard of Woodhouse, Buttermere, Crummock Water, Cumberland. We finally found it.)

Here. This is where Bernard (brother) found such joy when he was back about ten years ago. He stayed at this farm wth Brian for over three weeks. We used to visit Woodhouse as chlldren; Mother and Father would pack a lunch and we would eat nearby and join the two sisters (who Iived on the farm) for tea. During one of my first visits back to the Lake District, I went with a small group to a farmhouse like this where, for sixpence, we had tea and biscuits.

RR: Can you elaborate un the Lake District landscape; was it hilly, open, forested, l'lat?

Before the wars it was mostly forested (afterwards it was deforested). Penrith was furested during my chlldhood. When we went out with the parents to read poetry, we would usually settle in a spot where tre bracken was five or six feet high: The kids would find a co $6 y$ spot and we would each make a little hut of the dried bracl:en, Just far enough--or close enough--so that we could hear Mother and Father spout pootry; it would flow out in long ribb.sns. Mother did Longfellow's Hiawatha very well and Father was hepped on Dickens. He had each character's speech colored with a different color so that he knew which character was coming next; he really put himself into it.

RR: Do you rememlier anything about the landscapes in 
Hiawatha?

I do remember the $t$ when we reached America I was looking for the kinds of things Longfellow mentioned. I continually hunted for indians.

At Penrith, each of the children had their own garden. But Father's garden contained stiff, formal paths to which we had to keep. This was like Father; he had a narrow outlook and life, at home, was narrow. I hated the confinement and was continually running away. At each teatime, I would take an extra cookie or biscuit and add It to a tin I kept in the nursery. Whan the tin was full, it was time to run away again. The parents never caught on.

RR: What was the purpose in munning away?

I wanted very much to be alone. In a wild place if possible. In Penrith, I dreamed of Ilving with the gypsies that wandered through the Lake District. I loved their "roamingness" and they carried a sprig of rowan over the front of each wagon for good luck. I never got to them. because everyone around Penrith knew that I was Edward Lester's daughter and they turned me in. When I came home, Father would always be waiting at the gate with his arms wide open. I've always had a grudge against foxgloves. One time I stopped at a quarry to eat my running away biscuits and the men there saw me and notified Father. In America, running away was more fun --except at Westown where I was punished severely--for I could get farther and I was always discovering new plants that I had never seen before. It was beautiful in Kansas when the wind blew across the prarie grasses and I could sit and watch the undulating waves knowing that $I$ was free and in a wild place.

RR: When you go bask to England this Spring, what do you want to do or see?

More than anything "Ise I want to sit in a fleld of Primula farinosa and soak up the pinks and lavenders.

RR: Can you describe this field?

Yes, it would be lj.ke the field down by San Jose Creek where they are making thit polo field.

Then, I want to go to the farmhouse (Woodhouse, Cumberland) where Bernard stayed. (note: the postcard had been on the wall of Lester's study since Bernard had sent it.) I'm not as anxious to go to lenrith as I am to get to this farm. I'd also like to drive around the Lake Vistrict while I'm there. 
(note: The following comment should be inserted at the asterick on the preceding page (2.).)

In our children's garden, each of us coild do what we wanted. I remember once, the coachman told me that if I planted a cowslip upside down, it would come up double. I planted one in the way he described, but it died. I think that this experience shook my faith in humanity a little.

\section{March 2.}

RR: I'm interested in knowing what books or what people influenced you prior to your "emancipation."

Well, who's that chap who climbed to the top of the tree in a snowstorm.

RR: John Muir?

Yes. I read him quite a bit. I really began with Chase and Saunders. I guess that I began with Chase; he was the chap who traveled up the coast and said that when he reached the hill overlooking Monterey he could smell fish and sanctity coming up from the town below. I knew both Chase and Saunders very well. Chase was born in Penrith and Saunders was an American Quaker who was the first to write about wildflowers. He(Saunders) came from an old Quaker family in Pasadena and settled there because of his TB. He was a good camper and kept his pores opened; some Daleas are named after him. But Chase wrote better because he was British.

RR: Could you explain that?

Americans sling their words around any which way to get their meaning across. This and chewing gum used to irritate Mother and Father more than anything else. Father used to say, "Why don't these Americans finish their meals before they leave home?"

RR: What was the driving force behind your becoming a plant collector?

I courdn't find what I wanted in books. One has to find out for oneself by going to the source. I wanted to feel a oneness and a part of the whole.

RR: Can you describe an ideal plant landscape? 
The contours are important; this gives a "feel" to the place. It's nice if there are several exposures. You look at the site and decide what should be kept. Try to produce something that won't stick out like a sore thumb. It must harmonize--blend with the surroundings. Like this garden here.

RR: Tell me about your garden.

Shrubs and bulbs, mostly; things that could exist while I was away. Most Mediterranean things do well, here. I feel very apologetic about the Torrey Pine. This hill shouldn't have trees and I've turned down many good ones because they just wouldn't look right here.

RR: Also, wouldn't trees affect your view?

Yes, very much. I like aboveness, openness, space, long distances.

RR: Why do you think this is?

I don't know, really. Nursery life at home was very confining. I always yearned to be away--alone. Perhaps it was a rebellion against always being told things when I wanted desperately to find out for myself.

RR: Do you recall ever experiencing this "aboveness" or "openness" before your "emancipation?"

Yes! When I ran away in Kansas and I got out on the grass prairie. There it was flat, open and exciting. The farther away I got the richer and more rewarding the experience became. I continued to hope for indians, but the real reward was in finding nem plants which I had never seen before. For instance, the Gladdalias (sp?) in the composites. One of the richest experiences in my life.

RK: How did your father feel about this running away?

He would wait at the gate with open arms and I would run into them. But he was harsh on Mother and I was always the one who was elected to go to him and ask him to patch things up with her. The harshest thing he ever said to me was, "Mind your own business!" He carried the burden of what he had done to the family, but he wasn't willing to take responsibility. Mother always thought that she was having too many children, but Father shrugged and said that God would provide for them. He was a nice little man to have around the house. He had canaries; I didn't like anything that was caged. We had a large aviary in Penrith. 
I remember when Amy left home. She and the parents had a terrible fight and she cried for many days. She won out and this was when they realized that their control over the children had come to an end. This added to Father's frustration, but he didn't understand about having to feed and clothe his children. After we had been in America for some years, his money ran out and he really couldn't provide for all of us. That was one of the reasons Amy had to leave. She realized she had to go out and find work. When Victoria died Wother and Father cried like children for quite some time.

I always felt that when I was leaving a mountain top, during my collecting days, I was leaving the real thing and descending into a sea of pretense. But, it wasn't so bad if you treated it all like a game.

RR: What's the best landscape you've seen?

The Carivou Lakes in the Trinity Alps. where the rare "weeping spruces" are. (Lester got out her old field copy of Jepson.) I'll tell you their name. When they rebound this copy, I told them not to cut off the margins for fear I would lose these penciled notes. The last time that I came across old Jep, he was ill in a hotel somewhere in the mountains; I don't remember where.

Here is the name of the spmce: P. brewerii. I always like anything that had the name of Brewer. He was a wonderful guy who loved the high mountains; you'll find his name on many high mountain plants. (She read a description of the gross morphology) Yes, the branches closed to the ground like a skirt. This made a cozy room all around.

$\mathrm{RR}$ : Like the bracken near the beacon?

Yes, yes! All kids love this. Do you know the old road from Gaske to the Oregun border. I was collecting up there once when I came around $a$ bend and found that the side of a mountain containing a field of Ladies' Slip ers (Cypripedium) had skidded down across the road. Here was this whole beautiful field of Ladies' Slippers astride the road. I had to turn back. I used to visit Homer and Mary white at the end of this road. Uld Homer had driven the stage in thet country and he was full of swell stories.

HR: Did you get any ideas from him that were used in the childrens' books?

No. I picked those ideas up from kids all around when I was collecting. Kids are íll of good stories. 
RR: Can you think of another landscape that you liked?

A lovely place north of San Francisco. It's a Coastal Sward--a large meadow of iris. All different colors: blues, violets. The Pygmy Forest was nice once, before people started to get involved.

Down in Baja there was a nice sward behind a bluff overlooking the sea. Un the bluff there was quite a varied flora: many wildflowers in the beautiful green grasses that would ripple in the breezes--the soft movement across the suard.

$\mathrm{RR}$ : Like on the prairie in Kansas.

No. And, I used to go down to the rocks and yank off some mussels for dinner.. I cooked them not knowing that, in certain seasons they might be poison. But, they made a fine dinner after simmering in the fire out there all alone-no people.

As I grow older I think that I can see beauty in more forms. Now, I get quite a kick out of the sky; it's always beckoning.

RR: Did you notice the sky in Penrith?

No. Just the flowers. Also, the Santa Barbara Channel Islands have always been a special place for me. Particularly, San Miguel Island, the one that is farthest out. There's only one place to land there--very isolated. I could go to the top of the island and have the wind blowing in my hair. I could look around and know that I was surrounded by water and that I was alone. The deer would eat out of my hand and foxes would bring their young within sight of me which is unusual.

On the desert I had a good rektionship with the coyotes. When life on this planet becomes extinct, the coyotes will be the last to go because of their canny and slyness. When I was walking somewhere in the evening, they would glide along in the shadows, one to my right and one to my left. Although it was difficult to see them. I could easily sense their presence. To develop this rapport, one must be absolutely alone. It never works when other people are nearby or when everything is not natural. landscape?

RR: Which do you like better, the English or the American

I really don't know. I drool with nostalgia when I think of England. I feel cozy, safe, at home, there. It's a small island that gives me a coming home feeling. I become aware of my feet being on English soil; it feels different. This is probably due to the nourishment of the rain over the years. Nothing is artificial because the rain is natural. 
RR: Are the English people a part of this feeling?

I think in wales and Ireland, yes. I remember seeing the shy men digining the peat out with their English spades. Their spades would leave a very pleasant pattern on the sides of square hole; a wonderful design. And, they would run behind a pile of peat. They could sing beautfully.

RR: Are the English self-conscious about their country?

Yes, they're cocky rather than self-conscious. They thinks there's nothing like kngland. They have a very definite idea of values and they think that the Americans can't show them anything. They're not swayed the way Americans are.

$\mathrm{RR}$ : Do they value that which is "real."

They used to, but the Americans taught them that this isn't the thing to do. They're awfully sure of themselves; my father was like that. Americans?

$R R$ : Do they have a greater sense of history than the

Oh, yes. It comes out in school. We had to learn the names and dates of all the Kings and Queens.

$R R$ : Is this expressed in any other way?

I cant say; I really don't recall.

RR: You said that the English landscape made you feel cozy and at home. What about the smericar landscape contrasted to this?

America, especially on the desert, gives one a feeling of grandness, bigness, of space but of a place where one can find things that aren't already in the books. For instance, I was following the San Joaquin River up a steep canyon when I sat down to make some notes and started to sing. A most gorgeous lizard came out and climbed up on my right toe. It had very expressive eyes, bands of gold and chartreuse and was very handsome. As I continued to sing, it walked up to my right knee and went to sleep. I stopped singing and it opened it s eyes and said, "Go on." I have since tried to find out what it was by looking in ali the books but to no avail and I wonder really how much more there is to learn. 
1 chat wits Le, ter Rowitree

February 28, 1769

(Rowan Row:tree)

There were three things that a per on of my parents' generation had to knuw how to do: recite poetry fion memory, read alsud and pronounce one's "t's", and denonstrate good penmansh1p. Th1s wasn't necessar'1ly Quakeri but good private school English training. My parents used to take all of us out to a meadow below the beacons - - we called 1t Beacon Wood -- and recite Longfellow and Tennyson to us by the yard. It was pretty slushy: I remember Tennyson's May Queen as be1ng that way.

On Queen V1ctoria's anniversary they lit the beacons that had stood on the hill to warn England of the approaching Scots when there was threat of their coming down to take our cattle or our wonen. It was a sight to se = the "1res golng at the tups of each of the hills. We called them "nountalns" then, I thlnk, but they' were not really anything like what we've got over here; just hills really.

As chlldren, we were very well behaved. When sonone special cane to the house for dinner, we were allowed to cune dowastalrs. I remember well the time that Booker T. Washington came for a visit. He was the elrst black man I had ever met and we all sat around w1 th our hands folded and didn't make a sound. That was the condition on which we came downtalrs.

Because of John, my brother, we had some interesting people cone to our house. John played crlcket on the oxford team and traveled out to the colonles often. When the colonlal teams returned the match to England, frlends of John would cone to the house. When we left England for Auerica, John stayed on at oxford. I belleve he got his doctorate at Heldelberg before conlng to Amerlca to start cricket at Haverford. John taught most of his re alning professional years at the H1ll School. Jack, his son, went thruggh the Hill Schuol, on to Bverford, and finlshed up at Harvard. Since $1 t$ was publish or perish, Jack published got on at Haverford where he his taught English since.

I got the "slabs" yesterday. It's a seasonal thing that has to me in February for as long as I can remenber. They used to put me in bed when the "slabs" came on saying, "she has Spring Fever." Every time that I see Russell (Dr. W1Il1ams) he says, "Have you flgured out what causes the "slabs" jet?" And I return that he's the one who's supposed to find these things out. I think that I'm not yet fully a buman; still 
a wild animal that has to hibernate in February. I wish that I cuuld so to sleep and wak u! in a month.

I was really at sea the two nights that I was forced to stay in that tract hone (Clark's no use in Danvilie) w1th Harriette and Cedric.

RR: Wnat was it about the house that upset you?

I don't know. It was artificial, a c nplete veneer. Notbing in it reflected ny taste.

RF: Nancy sald that it looked like everytining had been purchased with Blue Chip stamps.

Lamghter; Yes, and yet I know what the woman was like. I stayed in ber bedroom. It was the lanpitand; a braes wiggly thing that tryed hard to look arty. I've never felt confortable in other people's hones. The Hill is me and our homes should reflect our belngs.

Flowering Shrubs was the better bo ok. It had to be written simply becalse nothing had been done yet. I was broke, but I felt that I waited to touch Reality. I had been reading others' and I felt that I just had to get at the source. There $y \mu$ can be Part of It, do your part in the game. But you have to be discriminating and chuck out a lot of stuff.

You have to unclog yourself so that your pores remain open to The Ilght. Then you become a part of the Wholeness and find that for everything there is a Reason with a capital "K". But, honesty's the key; no pretenses. Boy, I was happy then.

RR: I asked her about the things people had written about her.

People never belleved me when I said that I didn't want publicity. They thought that I was putting it on, maybe; But, it districts frcm one's concern for what he's dang. It's no good.

Do you remenber that thing the Herald did? The chap talked to me for half an hour; how can he get anything from 90 years in half an hour? He was a decent guy, though. As 
near to decent as they come. I think that he ran out of people to write about. He really didn't know anything about me. Why did he call me a "Legendary fig ure in Botany"? I'm not a botan1st; I've never been trained in botany.

RR: What about the piece Cora Brandt did?

Diu she do one? Well, she was one of the first in the California Horticultural Socie ty. There was Jimmy west - -he was one of the best; really, one of the very best--and Sydney Mitchell and Rose. He was a dear with a sense of humor. We were all brought together by $a$ big frost and storm. The frost sired us and the storm damned us. I guejs it was kind of clichey; things mustn't be cllchey.

RF. Was Allce Eastwood in on 1t?

Ob Jes, when I knew her she was kind of a cherlshed reference plece. The last time I gaw her was at a callf. Hort. meeting and she had returned from a trip during which she had sat in Iinnaeus' chalr. She very much wanted to tell us all about it at the meeting. Finaliy, she cane down the alsle and pulled at my arm anc sald, "Come onf, Lester, let's go somewhere and talk." So we did and she talked; we had a good chat. She died shortly after that. She was qul te a walker. When she took the bus (in san Franciscd) she used to get off and walk ahead when the traffic got too thick.

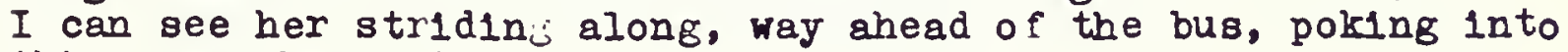
things as she went.

Kate Sessions was another one. She's a blessed menory; really knew her stuff. She had a nursery near San Dlego and when I'd visit her I wou d beg her to write $u$ her stuff. We'c go through her papers and I'd say, "This is good... throw that one away...save this, chuck that." We'd make two plles: in one corner would be the good stuff and in the other corner of the room wuld be the stuff I wanted her to chuck. Then I'd leave and the next time I would see her the two stacks would be all intermixed again.

In 1940, I was 8 olng through San Diego to a Fock garden meeting in New York and Kate had just broken her hip. I went to visit ber in the hospital. She was always pretty deaf and had to roar. When I poked my head in the door of her room she began roaring at me, "Lester, this is hell. Pure, unadulterated Hell." The nurses took me aside and told .ne that Kate wasn't eating at all and 11 we couldn' do something she would die? So I got her talking about plants and everytime she'd open her mouth, I would plop another bite 1n. The nurses pleaded w1th me to stay, but I had to get on to New York. After I arrived there, I got a wire from the hospital saying that Kate had died. 
She must have been a very beautiful wonan when she was young. But I doubt if any man had ever touched her. When she fell and broke her hip in the nursery, one of the men found ber. He told her that she would have to put her arms around his neck if he was going to get her up. She wouldn't have anything to do with 1 t and the poor fellow had to go fet/ch angther man to help him carry Kate. She's a good one, but she's nevel been written up.

The first $t$ me tilat I met Jepson I had Lady Bing in tow. When Lady Blng and I got to Berkeley Goodspeed heard abuut 1t. Goodspeed loved to make a show. When he found out that I bad Iady B1ng in tow, he wanted to have a reception for her. But I had no sikirt. So Mrs. Goodspeed took me arouna to all the faculty wives and I trled on skdrt after skirt. They were all much too long, but she fineliy found one belonglng to a daughter, I think. So we went to the reception and Jepson was there. He dreaded these things as much as I did. He had always thought I was a nan, I guess, (he addressed all his correspondence, "Dear Rowntree") and the Goodspeeds introduced us in we middie of the room. Old Jep was quite surprised and the faculty women 818 ied and danced around tittering, "He thought sho was a man, he thought she was a man." Jep sald, "Iet's get out of here!" So we got away and talked plants. I was on iny way to Modoc county and I quizzed him about his work, ubere. He had some cood 11sts. Finally, the ladies found us and Jep disappeared.

Goodspeed was a dreadful man. A four-flusher who liked all shок. No collector because he wanted the easy life when he went into the field. This was probably the reason why hls book about South American plants was 80 lousey. He and Mrs. Goodspeed camedown for a visit one time and, after talking for awbile, he soked me if I wouldn't write him up.

He talked Jimmy West into golag to South America with him to do his collecting. Jimmy nromised to go if Goodspeed woulon't reveal West's true identity. This worked for a time until they got to a place where Goodspeed couldn't get a decent hotel. Everything was filled up. Goodspeed mentioned to one of the hotel managers that he was with (West's German title) and things opened right uo. Goodspeed got a comfortable room. (He never slept in the field) Jimmy never forgave hin and, shathly after, disap peared for Germany where $I$ hear be was caught by the Nazis and thrown in the Rhine. He was found floating with a smile on his face. 
The last time that I saw Jimmy, he came down to visit me when I was holed up in the little study at Clevenger's bouse (RK: either just before or auring the time when IK's house was being built). We talked until about two $L M$; Jimmy had an old red sweater with safety pins holding it together. There was no flat place outside where he could throw down his bag. Then he spied my compost, just below the bouse. Jimmy said, "There's a perfect place; it's flat, soft and warm." Some time befor Jimmy came down and asked if be could go collevting with me to Mexico. I wasn't worried abuut having a man around because the plant people were all on the up and up. But, I didn't have the time so we spent seven days collecting around in Central California. Jimmy was one of the beat of them all. night?

RR: Didn't Jepson lock jou into the UC Bot garden one

No, that was Jim Roof and Bachigaluppi (ap?). I was returning from field trip and wanted to get home but atopped to see the new garden. They had just acquired a new fence and gate and Jim was doing some kind of experiment. Jim and Bach showed me around and we talked until dark. I told them I had to get going and Jim turned to Bach and said, "Got the keys?" They let me and my gear into the garden and locked the gate. I had a voderful bath in the creak (Strawberry Creek) and a sound night's sleep. In the morning they met me at the gate, let me out and took me to breakfast. Bach was a great guy and I like Jim very much. I wish that held come down again.

RR: What happened the last time Jim was down?

Well, old Jim said be wanted to ask me a few questions and we went into the study. I was nerched on the couch and Jim was sitting in his chair with what looked like a briefcase open on the floor. He started asking me some questions and, as I talked, I noticed that he was fidding with that thing on the floor. I said, "Whot's that thing, Jim?" And he kept fiddling and asked me another question. I said, "That is that thing?" He finally aid something like, "Nhw just a tape recorder." So I clammed up. Jim's great fun.

RR: Did you ever meet Herbert Mason?

Yes. I was out on the dunes at Pt. Reyes looking for a and wo rking from the bottom of the dne up to the top. Aa I got to the crest, a. head apeared from the other side. We looked at each other and he" said, "You're Iester Rowntrea." I said, "You're Herbert Mason." We each nodded and continued our work. 
Lester Rowntree; some memories (Rowan kowntree)

$\ln :+i ;, i c ;$

It is the morning of March first, 1969, and Grossmama and I sat on the flagstone steps at he south end of the house. Last night's talk had been productive and she was in a mood to tell me as much about her family as I wanted to know. For the first time in weeks, the sun was shining and the garden was atarting to come into bloom. I was aware that it had been several years since I bad heard the little creek running below the place where we sat. I think my purnose was to encourage her to tak about the olaces of her past. But, her memories for the most part consist of people and experiences. When I asked ber specifically about aspects of the environmenta in her past, she was evasive.

RR: Tell me about the Quakers in Penrith.

Well, in the Lake Country the Quakers were all right. But, when they bot to Ameica they became too stuffy--too fundamental. Then Hicks broke away and started something more like the Unitarians. His groun (tbe liberals) were called the "broads" and the fundamentalists were called the "squares." I visited the Hicks family in Iong Island and liked them. The Quakers in the Middle West got to ainging and baptism and paid a pastor; they were like a chead Methodist group without the water.

When I went back to Penrith, the meeting--our meeting-had been "laid down" (discontimued). When we were there as kids, I remember that the jrownups were al very stuffy and wore bonnets. None of us like to go to meting although the community of Quakers were very close--all one. The meeting bouse was a beautiful old stone building (no elaboration; RK) and the Lesters just about filled most of the benches. There was a Miss Peal who always got to meeting first and sat in the front corner; when we arrived we had to fill in next to ber. So, before each meeting we (the children) used to cast lots to see who would have to sit next to Miss Peal. She had indigestion and, during the silence of the meeting, she always got the widdles (noisy stomach) and started the child next to her giggling. Then the giggling would soread down the line and to the next bench. One Sunday, though, Miss Peal gave the child. next to her a candy. That changed our whole outlook.

The Quakers are really the simplest thing there is. It's the core of every religion ( $I$ din't like the word "religion"), but personalities have made each different. It's too bad that when Hicks broke away the fundamentaliats had to reinforce them selves by becoming stiffer and stiffer. 
RR: What was the meeting house in Penrith like?

Simple. Not pretentious.

RR: Well, then, would you say that the Lesters were liberal Quakers?

No, not in England, because we wer. all one. But when we sot to America there was this snlit. In Gatina, Kansas, we went to meeting and everything was btrictly fundamental. When we got out Dad said, "That's not Quaker !" When we got to Pasadena, we went to meeting and it was awfully noisy. Afterwards, Mother said, "That's not Quaker!" There wasn't much in between.

\section{RR: What about Galina?}

Well, one day back in Penrith, Father called us a'l to come down from the nursery to hear an American lady who was going to tell us about a place in Kansas. We ssat around with our hands folded and she spoke of a fine communit.f of English Quakers, private schools, libraries and doctors and sood land. Father's trouble was that he always thoubnt he knew things that he didn't. Because ho was a talented gardener in Penrith, he thou ${ }_{i j}$.t that he could become a successful rancher in Kansas. He always took everyone at their word and it was inconceivable to any of us that the land we had bought was going to be ay different from the lady's description. Father saw quite an opportunity for the boys in Ame 1 ca because they were limited to few profesaions in England.

(Victoria jot $m=d$ at the Quakers early in her reign and prohibted them from entering any of the nrofessions except for, I think, the Army--and that was out!--business, and the church. She relented later.)

My Uncle Henry was a physician who did research on childrens' diseases in the London slums. When he had become well-known, Victoria sent for him and wanted to knight himx because he was doing good. Uncle Henry said thank you but he didn't want to be knighted for his work.

Another Uncle--I think his name was Joshua--lived in Brickaton (a Iondon suburb) wher: he had a mill. I recall that he had beautiful beds of auricula. When he had to go into Iondon to deposit his money in the bank, he used to ride alone on his horse. Everyone said he would get robbed, for those were the days of the briganas; but my uncle said, "I'm protected because I'm a Quaker," and he went on unbarmed jogging deily into London.

Father was on the Board of Heath in Penrith. When he went to his meetings he used to come up to the nuraery and kias us af goodbye. When he left, we'd get out this board and jump up and down on it thinking that we were doins what the men of the town were meeting to accomplish. We thought they were getting together to jump on a board for their health. 
RF: Then you went to Galina?

On the boat, I remember that Bernard and I found a place where we could look through the deck grating and see the steerage people carryinj trays of food. We used to drop burnt matches on the trays as they were being carried out. I kent a diary of the trip and the time in Kansas, but it was lost in the fire.

After we reached Kansas, we noved several times before we met disease. I think we started at Galina, then to Thajer and Medicine Lodge, and finally to Quakervale.

RR: Tell me about the ranch.

There was a river, a house, lots of land, cattle, horses. There were no schools, no doctor for 30 miles. Nothing. lother finally stated a school. Father was useless in this sind of a situation, althoush Mother came through. We found out that all the peonle who had lived there before us had either died or moved out. The well had typhoid. The summers were extremely hot and we mide hammocks to hang on the trees down by the river. This is where we slept and I'm sure that the mosquitoes that bit us nizhtly carried a little malaria.

Ethyl went down first. When Mother knew the seriousness of her sickness, she sent me to a neighbor's house and told me to stay until the day when I was called to come back. They told me that if $I$ had faith and prayed, Ethyl would IIve. So I prayed and prayed for several dajs, for I loved Ethyl very much. Then, somebody came to this house and told me that my sister, Ethyl, had died. I begged his bardon, but my sister had not died, for I had prayed for her. They said that I was wrong, so I snuck back to my familg's house and went up to Ethyl's room and the door was locked. I went outside and shinnied up the drainpide and got in her window. She was there on the bed with a sheet pulled over her. When I pulled the aheet back, I saw ber face--the fever had come out all over--and I was assured that she was dead. There, I vowed that I would never pray again for it was a lie that praying would save someone whom you loved.

The doctor, who had come thirty miles, predicted that Bernard would die one nibht. Mother stayed uo with him and I awoke in the middle of the nisht to see her rubbing his feet with tears streaking her face and ber lips moving in prayer. He lived to the doctor's surprise (RK: Derhaos this haooened before Ethyl's death). Mothel was wonderful; she said tbit she was just not boirib to jet it.

After Ethyl died and the rest of us could be moved, the quakera came and took the whole family to the meeting hoube in order that tney could help Mother with the job and to get us away from the infectied ranch. But Howard, who was the anjel of the family and who sang beautifully, wanted to stay to care for the animals. Agrinst his parents wishes be stayed on while 
we moved to the reetin.5 house. After two or three days, there was a knock on the aoor ard there was Howard, comsletely delirious with fever. He was quickly put to bed and for two days and two nights he sang and sang in bis beautiful voice, in delirium. Tuen he died. I loved nim nrobally nore than any other brother; he had a sense of humor in the droll English vein and was beautiful.

RR: Can you tell me more about the family?

Frank was the oldest. He went on to be the head of a state college in New Mexico. When the Kepublicans came in, he was thrown out. He came to California with his first wife; she died out here. Then Frank married his secretary from New Mexico and they started their rose business in Watsonville. Frank was a good mixer; aiways seemed to have lots of lady friends. When he was young he had a little mustache of which he was very, very proud. Marge was his second wifes name.

Next was Leonard. He had an awful temper and was wedded to a little hammer. He almost killed John one day when he hit him on the head with it. Mother devised the "dreadful accident book" in order that all of us could take out our aggressions. When she sensed that we had the need, she would suggest that we make an addition to the "dreadful accident book" and we would draw something anproni iate. Afterwards, we folt much better. Leonard was telented: he sarb, painted. He spent ebout eisht years in Munich at college.

Thercame John. He stayed at Oxford when we came to America. After that, he went to Heidelberg, then came to Philadelphia.

Howard was an agel. I really loved him. He had a real sense of humor.

Amy was physically beautiful. She was the lady of the family and I was always compared to her.

Then me and Bernard was younger.

I love Father in a dutiful way. He was a gentleman; very talented, good looks and a good voice. But very selfish. He could mimick quite well. Mother was lovely in a wholesome way. We loved her dearly.

RR: And, after the deatha?

Well, the Rowntrees had read about our sicknesses in an English Quaker newsnaper. They lived in Westoort, Missouri, and wrote Mother and Father with an invitation to come to them for a reat. We liked the Rowntrees; Mother ard Father thought that they would be good for us. They were fundamental Quakers and went to meeting every sunday in black. So, we moved to 
Hestoort. We called charlotte "chats" because she was a dreadful talker; sne was sinall like a wren and reijned over the 13 children.

The Rowntrees went to neeting in Kansas City and always came by on their way home. We would watch for them to come across the meadow dressed in their black robes; 13 boys. And we'd say, "Here come the blackbirds!" They wo!ld all come in and try to sing hymns with us, but they were all tone deaf. It was terrible. May of my family sang well: Father, Mother, Howard, Leonard, Myself. After I was married and lived in New Jersey, I took some training and the teacher asked where I had learned to drop down (from above) on my inigh notes. I said that I'd learned it from the Canyon Wren.

The year I came to Westown the school still punished students for singing. I was punished and punished, but I kept on. A Canadian girl and I--she was a good alto--used to sneak out into the woods and sing. Pretty soon all the other kids found out and the occasion became quite a popular one. We were all caught and punished, but the next year they did away with the rule against singing.

RR: Then, after Westport, did you move to Altadena?

Yes, we sold the ranch and set out for an English Quaker colony near Pasadena. Father was sure that we could grow all sorts of fruits and make our American venture better than what it had been. By now, he was beginning to carry the burden of what he had done to the family in making us all come to America.

There were only five houses in Altadena colony when we arrived. The hills were beautiful in the Spring with many wildflowers. We were sent to an American public school nearby and were ridiculed for our English accents. So, one day we locked ourselves in our room and began practicing how to talk like Americans. We practiced our "ain'ts" and our "yeahs" and the appropriate grunts and drawls. When Mother and Father caught on they decided to send me away to Westown, along with Bernard. I wanted to go on to Ambler (a hor ticultural college) after Westown, but Father called me home to help take care of Mother. It took her four years after that to die.

After Mother died, Father wanted to move back with John who was teaching at the Hill School in Pottstown, Penn. 
One day, while Father and I were living with John in Pottstown, Bernard Rowntree turned up. He had visited me while I was at Westown and, at that time, he was int ent on converting everyone to a fundamental belief in God and Jesus. He used to go around puting placards up in trollies and when he came to the school to see me he would bring a slew of texts along. The other girls knew what was golng on and when Bernard and I would stroll through the campus they would follow. Bernard would read a little tract to me. When he'd start on the next one, he would give the first one to me and I'd drop in behind my back. Bernard and I left a trail of little tracts through the woods and the girls would play a kind of hare and hound game with me. It was fun and helped me get through this stage with Bernard.

RR: Was he trying to convert people to Quakerism?

No, although they were fundamental (in the American sense) Quakers, it was not characteristic. It was more of a baptist "Jesus saves" approach. Later, Bernard went to Woodbrook which is the English equivalent to Pendle Hill in America. They straightened him out.

RR: You said that Bernard turned up while you and your Father were living with John?

Yes. You see, Father was a problem. He was used to being car for, being the youngest in his family and having a wife who was wonderful along these lines. My brothers weren't in a position to care for him because their wives didn't want him around even though he was very innocuous. In addition, a girl about flve years older than myself, Miss Clevenger, had asked to stay with me because she had no family. I coneented. So, when Bernard proposed marriage, he offered to take on my father and Miss clevenger. We were married in 1908; I can remember that date.

We rented until we built the house in Oradell, New Jersey. Neither of us wanted to live in the city, so we bought this east-sloping property on a hill a mile from the train station. Ittook Bernard another hour to get to New York.

RR: Can you tell me about the house?

We both wanted to be walled in. The wall was made of native stones with a large gate at the front. We planted the rowan trees across the front.

$R R$ : Why did you want to be walled in?

All English people like walls for privacy. We had a wall at Penrith. In the wall at Oradell, we had a little "escape gate" made so that when a visitor stayed too long, we would show him the garden and the path led right to this little gate. He had no choice but to take his leave when he saw this little gate standing halfway open before him. 
RR: What was the house like?

As one came in the gate there was a large expanse of lawn in front of the house where we had tea in the summer. Along the drive was a bed of Lilies of the valley. I used to give away parts of this bed every year.

RR: (note: the following description of the house and the garden came out bit by bit. My questions are omitted, here.)

The house was two stories in the front and about three storles at the back because the hill sloped down to a creek. A screened porch enclosed two sides of the front portion. Here's where all of us slept, even in 10 degrees below during the winter. I made a lamb's wool sleeping bag for Cedric and Bernard rigged up some iron hot-water bottles for our beds. Cedric was the healthiest child in Oradell because he slept out on the porch. The interior was on the English plan with a passageway and the rooms opening off of that. The interior was panelled in chestnut.

RR: Would you consider the design or proportions to be along Quaker lines.

No, I don't think so. Bernard hired an architect to do it. It was solid and homey. That's all.

$\mathrm{RR}$ : How about the garden?

The garden was very lovely. It got quite a good name in that area and people began coming and askingto see it. So, we opened the garden to the public one day a week. We'd lay low inside, but there were sometimes twenty-five people in the garden on those days. It was really gorgeous. It was terraced down the slope with the fruit and vegetable garden just before one came to the "woodland garden" that bordered the creek. I really was a good gardener; it's the one thing I could do in life. After I had moved here to Carmel, a gentleman came to the door and wanted to meet me. He said that he had bought our house in Oradell and that I was a legend. He sald it was because I was the only woman who wore pants in the garden.

RR: How long did you live there?

Well, I had had some trouble during pregnancy and after. They said that I had terminal cancer and I was taken out to Pasadena for an operation. During all this--I guess when Cedric mas about eight or ten, Bernard and I became interested in Theosophy. Katherine Tingley, who was head of the movement in America (there was a similar movement in England), 
had started a school at Pt. Loma, near San Diego. Spaulding (sporting goods) had sent all his ukids there and was supporting Tingley. Leonard was teaching art and Amy was also there. I didn't like Tingley. However, she offered to take Cedric while was having the rough go. We sent him out, but he ran away, I think.

\section{RR: Why did you move out to California?}

I had to return to Pasadena for another operation on my Insides. This time they took everything out and said that I would be an invalid all my life and had better move out where we could be closer to the doctor. The only doctor whot I trusted then. While I was recovering from this operation, Bernard and I drove up to Carmel and fell for it. After we left Oradell, we went first to Santa Monica. Mhen, we came to Carmel and rented a house in town while we built the Highlands house.

RR: (note: the following comments came out with some visible reluctance on Lester's part.)

When we built, Bernard ousted Miss Clevenger. She got some property just above us and there was some altercation in court. Also, Bernard's work wasn't doing as well as we had anticlpated and he became very depressed and didn't speak to me for ovei a year. We had sent Cedric away to Westown and, at the beginning of his summer vacation, he became avare of the problem and suggested I get a divorce. 'This was difficult becaus $\theta$ we were both birthright Quakers, even though we hadn't gone to meetings. I tore myself away and went up to live in the downstairs study of Miss Clevenger's house.

I was convinced that I was going to starve. And, every morning that I would awake and see the sun I would be cheered that I had made it another day.

RR: Is this when you started the seed business.

I had been exchanging seeds for some time prior to this with Corovan in Geneva. He was the best in the world at that time. Also, I had done just a little collecting and was in correspondence with some other seed people abroad. The local plant nurserymen had encouraged me to start the business, so It was establishod by the time I got the divorce.

When I made the break, I1fe began. I had never been so happy even if I did almost starve. But I was a free woman and lived on ten cents a day.

RR: How did you happen to build this house?

When I was living in Clevenger's, I collected seeds up on these hills. When I came upon this little level spot, intuition said, "Build her. Build here." You can't analyze something like this. It was a feeling of "oneness"; a feeling that here was where I belonged. 
Old Devendorf--he was a good guy--gave me the land for a good low price. I a sked him about the hills in back of the property and he sald, "Lester, if you want them you can have them. Nobody will every be able to build on them and you'll just have to pay the taxes." So, I took his word. He really thought nobody would build on those slopes because he didn't think they could get a bulldozer up there. 
Jan. 12,1971
The Hill
Lester, Nancy and. I we

Lester, Nancy and. I were sitting around the fire in the evening, some of us flushed with wine. Lester was talking freely about her childhood in a way that gave us some insight into her mature and adult ralue system that we see to day. She talked objectively about some of her brothers, particularly Bernard and John. Then she abruptly exposed an Incident that she adnitted bas through her iffetime been very influential in guiding her overt actions.towards members of her family. This is an incident that I have never heard mentioned before by anyone.

It took place when she was about II years old, according to her, In the Penryth house and, 28 she described 1t, she was starting up the staircase when she met one of ber brothers coming down. She is not at all sure who. It was but she said that she felt such an upvelling of love for him that she sald to him "I love you" and he was astonished. After a moments silence be responded by repramanding her and saying you are a disgrace to the famlly; you should never express your emotions like that and you should never wear your heart on your shirtaleeve."

$r \longrightarrow \rightarrow$ Grossmama revealed that this incident affected her childhood quite markedly and her subsequent adult years durlng which she found it immoral or at least not acceptable to express outwardly any deep emotions such as feeling of love for another person in her family, whether that be her husband or her son, Cedric. I recall myself' that she many times used the expression "do not wear your heart on your shirtsipeven and the was very sure of herself in theopla taking the position that a good British Quaker and an y of fspring of a good British Quaker should contain his emotions and never really express them outwardly. Lester added that she had recently felt (this is recently in the last month or two as I understand it) an upwelling of love for Cedric, her son, which she felt an obligation to supress in terms of the outward expression of this love.

The supression of out ward emotion is not exezueively a maxim of Quaker culture. George Fox and his followers received the term "Quaker" ffict their overt manifestation of an inward light. The Britishnculture is perhap more responsible for dictating the idea of stableness of outward behavior. It would be interesting to find out whether or not American Quakers misinterpreted British Quaker patterns in a way that led the Ame rican Quakers to assume a typically British outward behavior pattern. No doubt the incident described above in Lester's life is typical of British Quaker upbringing and that one point or another in a child's life he or she 1s taught by older siblings or parents that this is the way you do or do not behave towazd other people. 
Viscountess Byng of Vimy D.G. St. J.* 1980-1949

Lady Byng, who was an outstanding woman in her own right and married to a remarkable man, apparently made two journeys with Lester Rowntree. Her wel1illustrated article, "California Jottings," was published in three issues of the Journal of the Royal Horticultural Soclety. + She says, "[I looked forward to] the cheerful prospect of another journey with Lester Rowntree, which started March 12, [1935], in warm sunshine but with a lightly clouded sky that gave an opalescent effect to the atmosphere as we trundled towards the Bakersfield district northeast of here and famed for its wild-flower display. But I seem 'hoodoo' to the Rowntree car as I was three years ago..."

Lady Byng was born Marie Evelyn Moreton, granddaughter of the second Earl of Ducie. She was an accomplished author. Her two novels, Barriers (1912) and Ann of the Marshland (1913) still read we11. In September, 1926, she inherited nearly four million dollars from her uncle, Pandeli Ralli, a Greek merchant. This money enabled her to buy Thorpe Hall in Essex where she designed and built a famous rock garden. She was a founder and president of the Alpine Garden Society of Great Britain.

Her husband, Julian Hedworth George Byng, first and last Viscount Byng of Vimy, was the seventh son of the Earl of Strafford. Born in 1862, he became a professional soldier. He proposed to his future wife by cable during the Boer War. His title was awarded for outstanding courage and leadership during World War I. Parliament voted him an honorarium of $\mathbf{7} 30,000$ for meritorious services to his country in war and peace. He served as Commissioner of the Metropolitan Pollce and Governor General of Canada. Later, he was promoted to Field Marshall, an unprecedented honor in time of peace. He died in 1935.

Lady Byng's autobiography, Up the Stream of Time, was written towards the end of World War II in Canada. Lady Byng's courage and good humor was as evident then as it must have been when she bucketed around California with Lester Rowntree, as open and observant of the wonderfully varied natural scene as she was of her companion's qualities of courage verging on the foolhardy and wide knowledge and deep love of California's native plants.

*Dame of Grace of the Order of St. John of Jerusalem: also Order of Queen Elizabeth of Belgium

+Journal of the Royal Horticultural Society, Volume LX, parts 7,8,9, 1935. 
Bulletin of the Alpine Garden Society of Great Britain Vol. 17, No. 4, December 1949, No. 78

(President 1936-1937)

\section{OBITUARY. \\ THE VISCOUNTESS BYNG OF VIMY.}

Evelyn Byng of Vimy - what does the name conjure up for us? A gracious hostess-a talented actress-a connoisseur of art-an author of novels and memoirs-a lover of ornamental water fowland, indeed of any animal or bird? It could be any of these things, but to the lover of plants it will be the gardencr that will come first to our minds. That keen enthusiastic figure in shady hat and overall taking us around her lovely garden which she had made at Thorpe Hall in Essex. It was always a treat to wander in the garden at Thorpe, but to be personally conducted by Lady Byng - to hear hor exclamations of delight at the sight of life in some treasure from S. Africa or California thought long since deadto witness her explosion of rage, accompanied by picturesque (sic) language at the sight of a rabbit on the lawn, were experiences not to be easily forgotten.

Perhaps one of the happenings that gave her the most intense pleasure was the fact that, of all the men who went from Thorpe to the war to take up their manifold duties, all those who returned came back again as soon as they were demobilised and asked to be taken on once more.

She was not an easy mistress to work under, her orders were clear and exact, and she expected them to be exactly and faithfully carried out and thcre was considerable trouble if they were not. Those with sense and ability did not fail her, and in return the position between employer and employed was one of trusted friendship.

At Thorpe people worked with their hearts in the job and not with one eye on the clock. The forcgoing applied to many of her visitors and notably to H.R.H. Princess Alice and the Earl of Athlone, who she always said were among her most capable and tidy workmen. Their jobs were gencrally of the lumbering varicty.

Thcre are a number of plants that bear her name and not a few that were raised at Thorpe. The garden world will feel her loss keenly. Those who met her are not likely to forget her, and we who knew her well shall hold her memory dear and be ever grateful for her friendship.

IRIS LAWRENCR. 


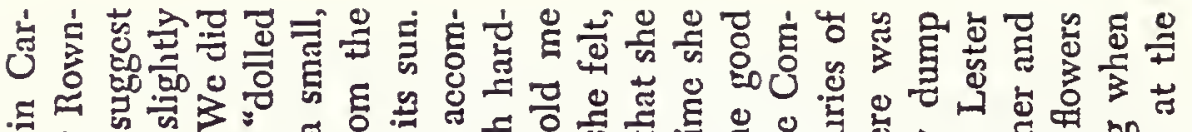
to 包

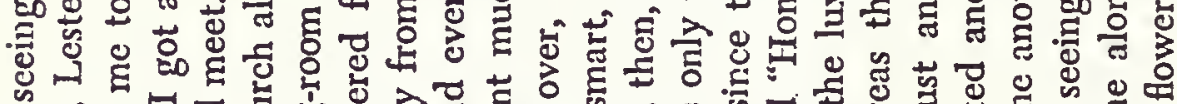
되

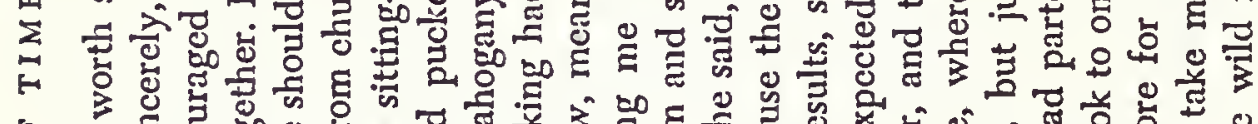
○.

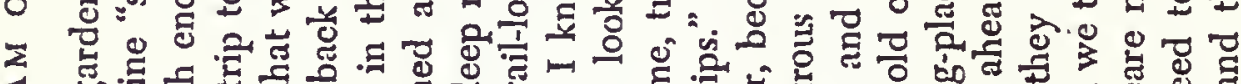
〈

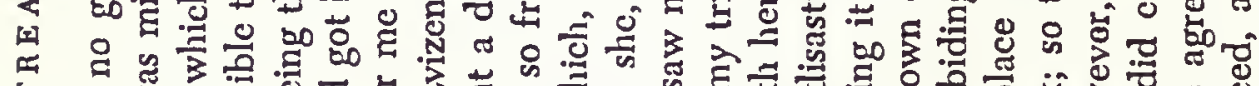

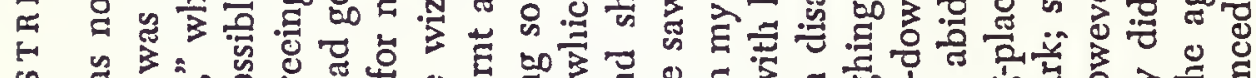

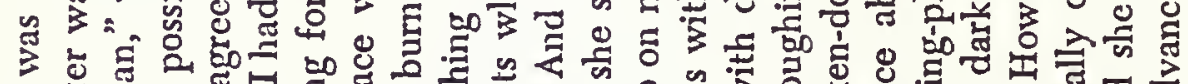

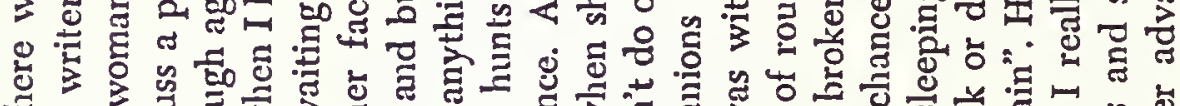

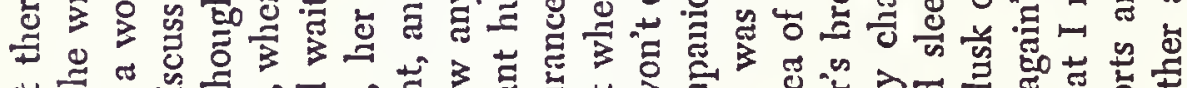

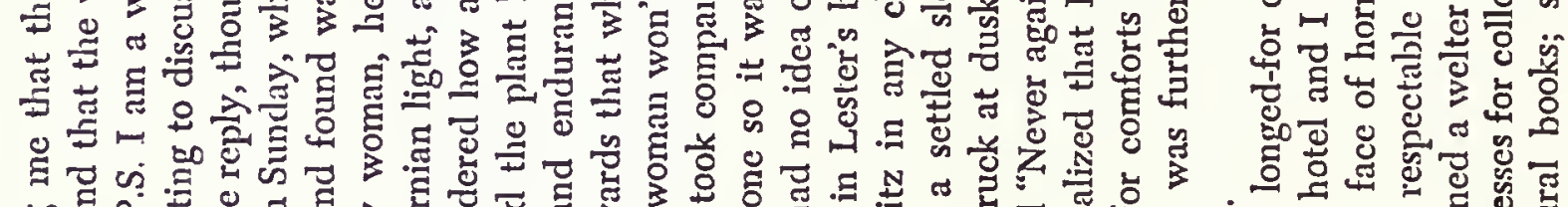

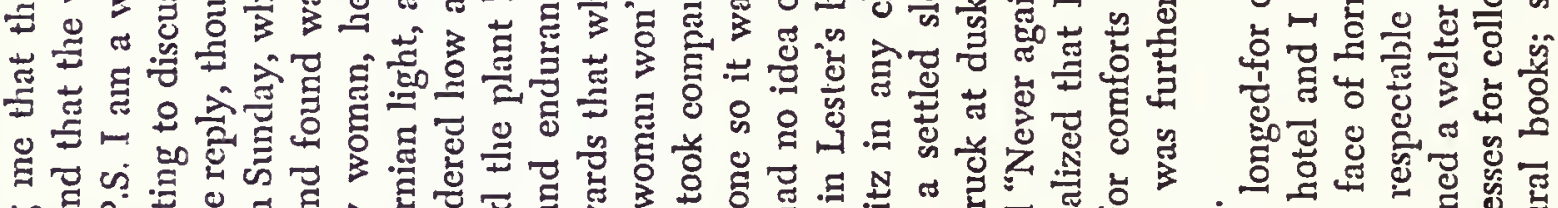

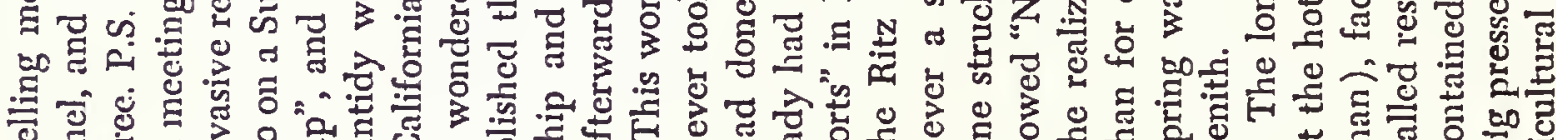

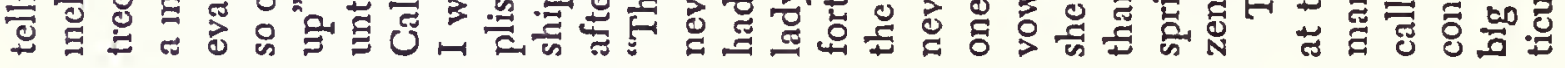

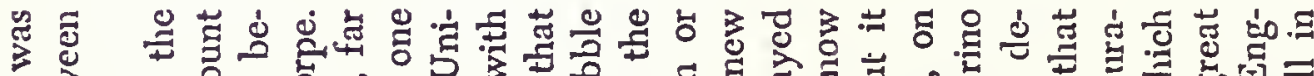

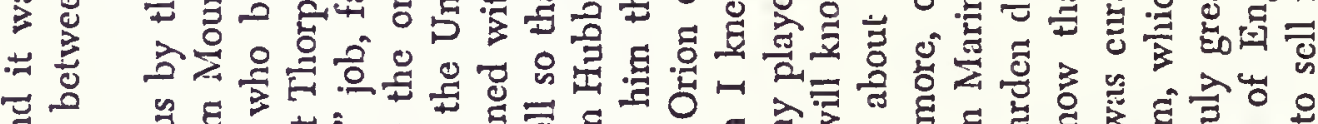

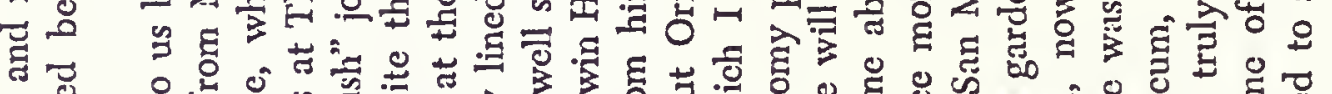
ڤ范

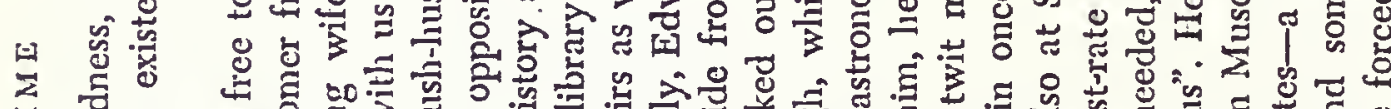
出远 -

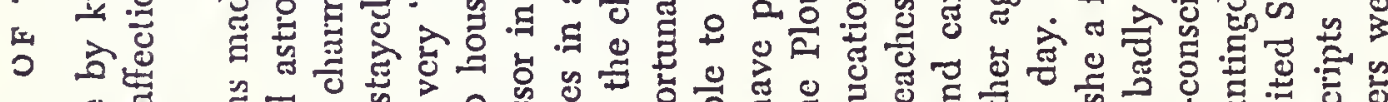

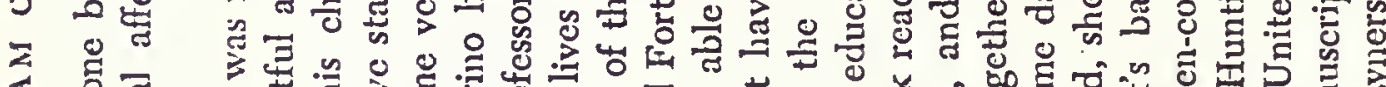
《

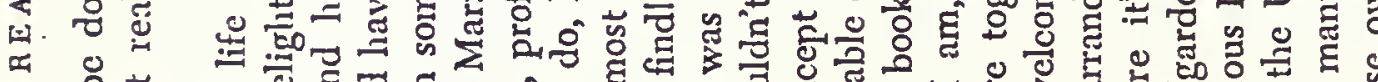
匹

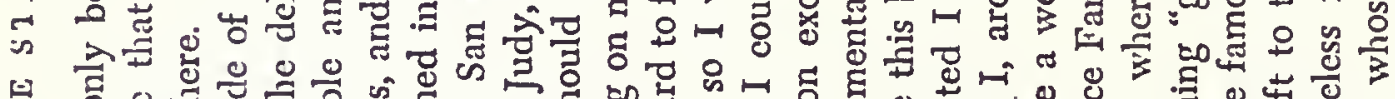

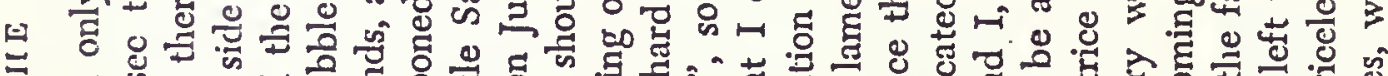

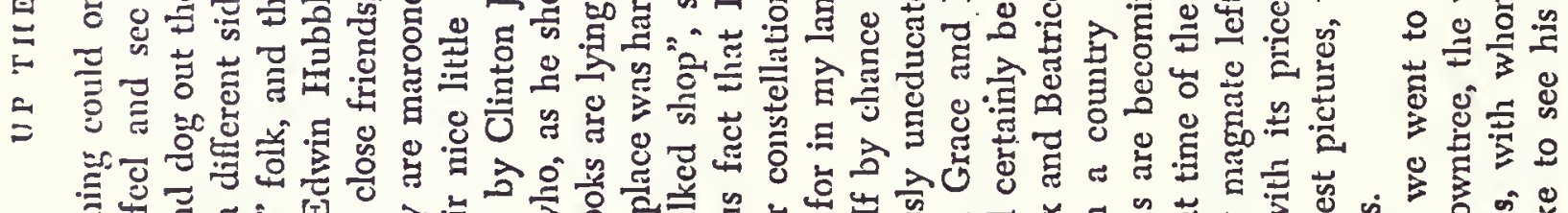

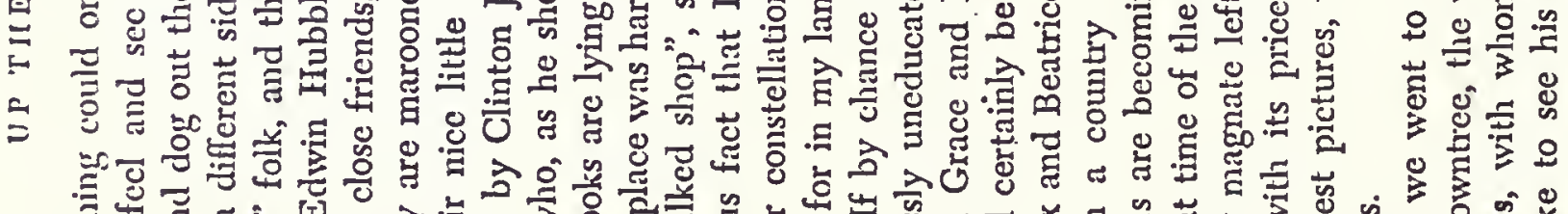

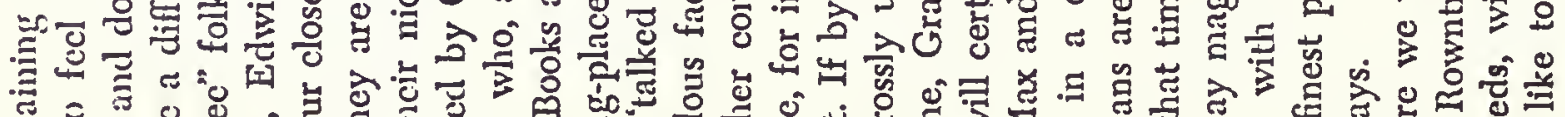
焉

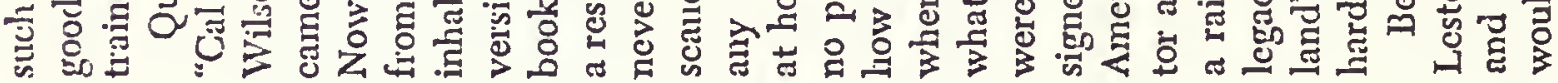




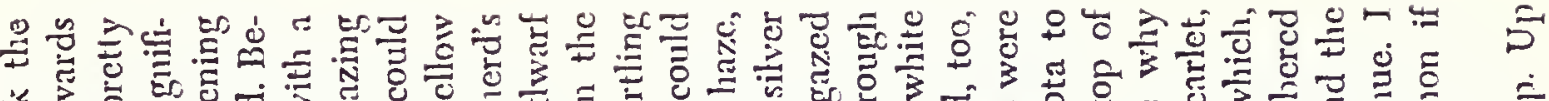

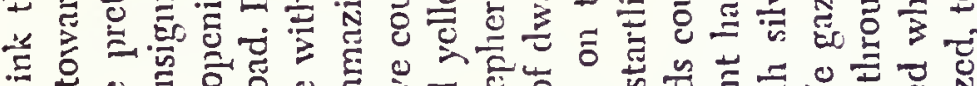

三。 આ

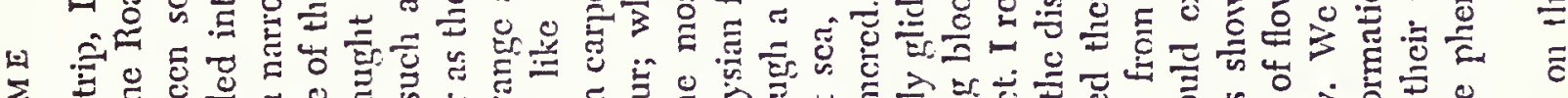

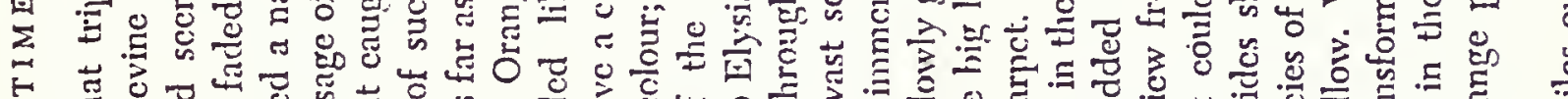

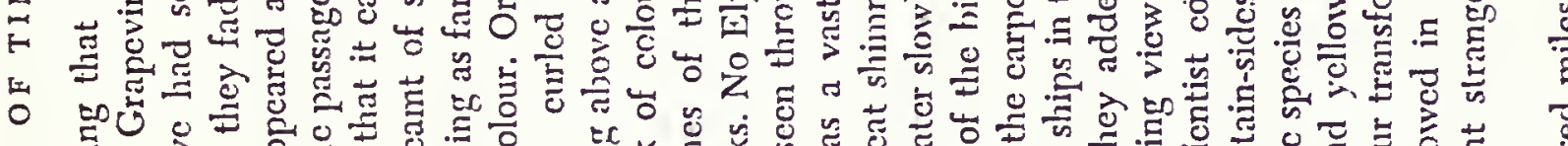

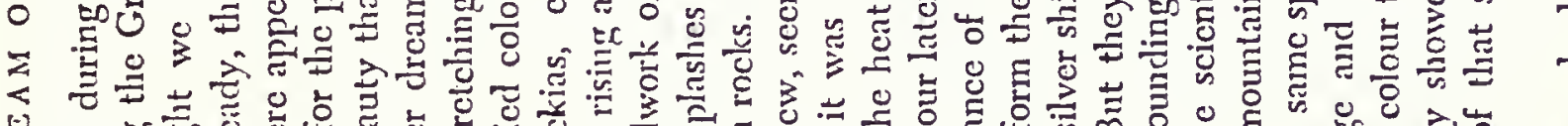

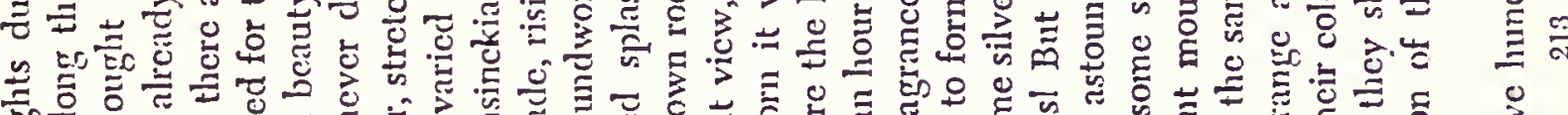

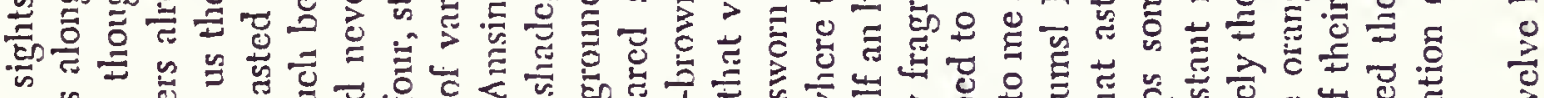

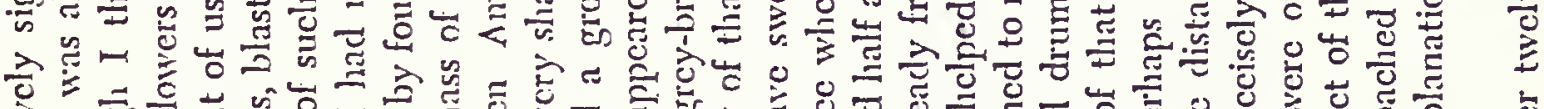

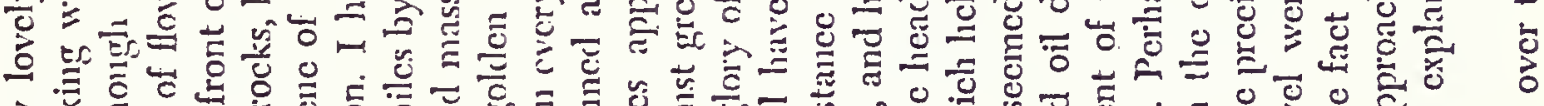

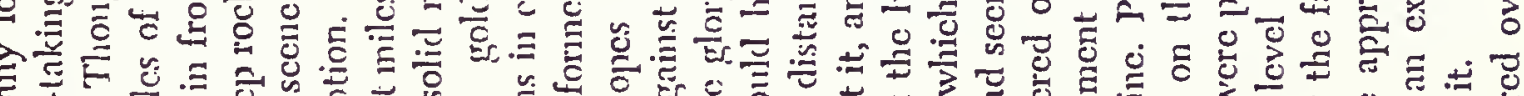

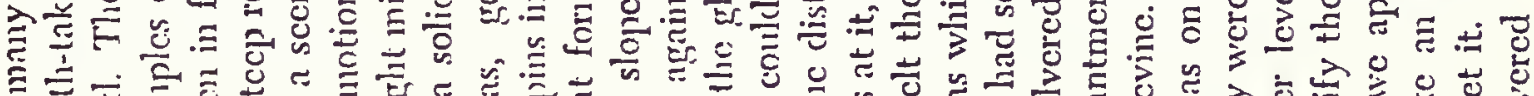

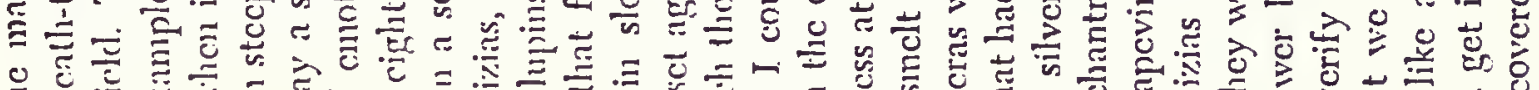

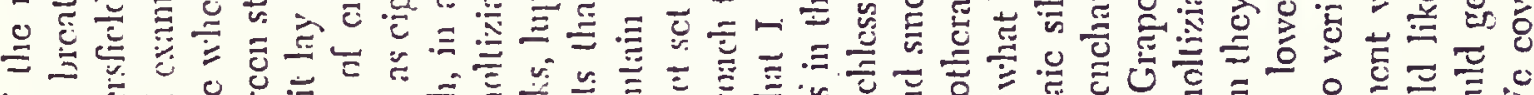

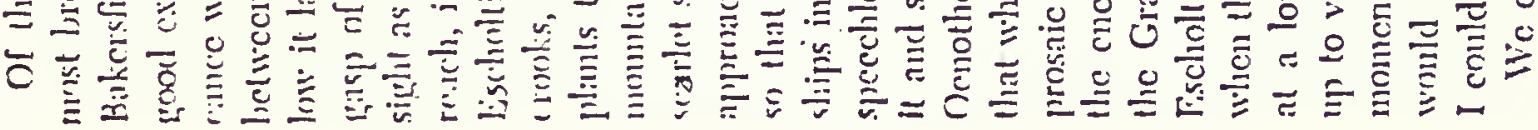

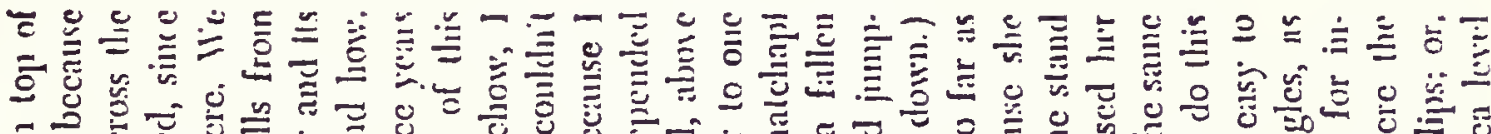

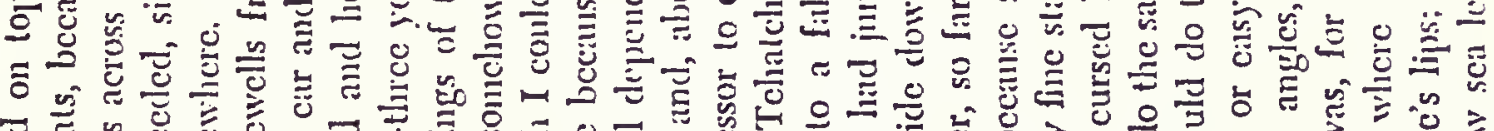

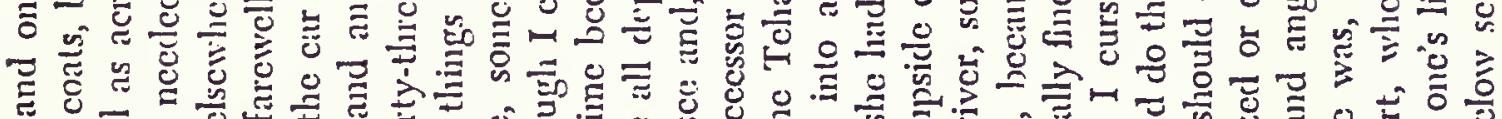
之

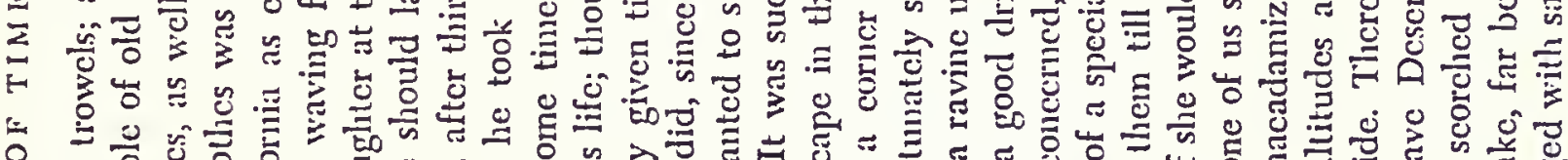

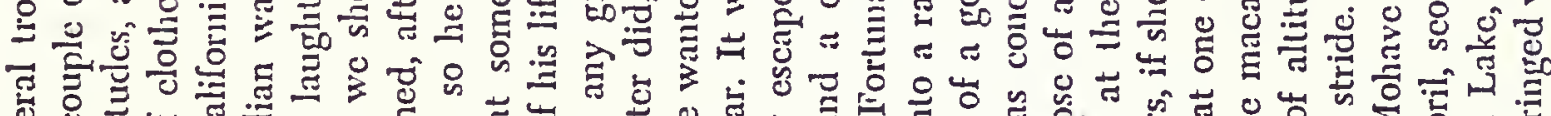
之 =

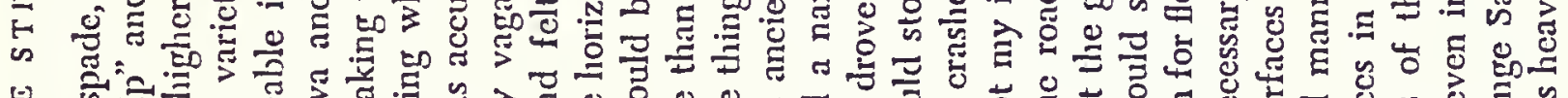

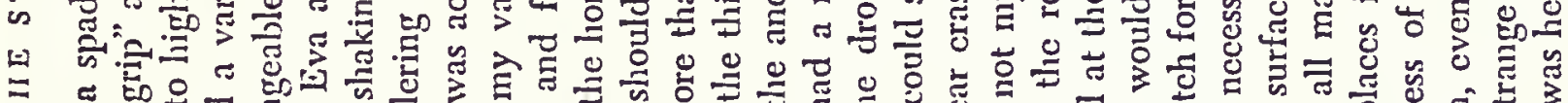
च ๘ 4

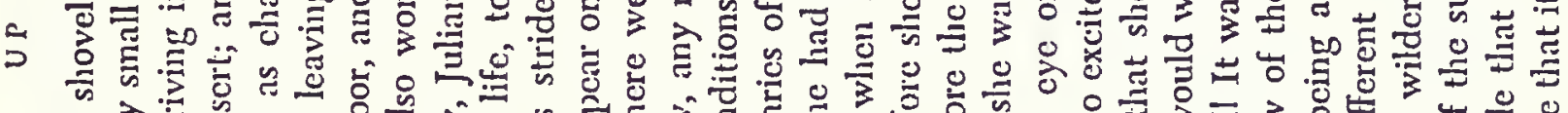

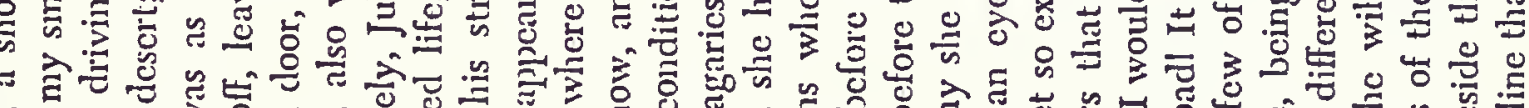

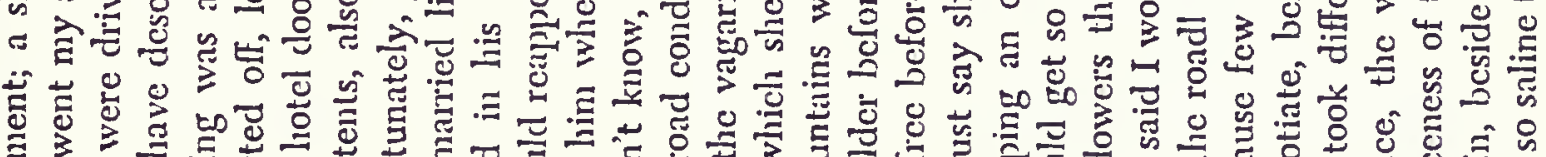

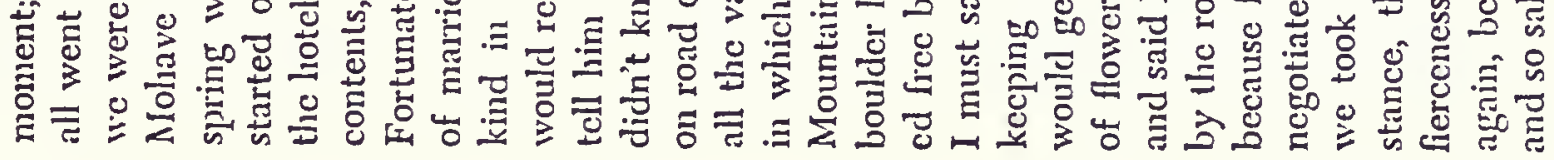




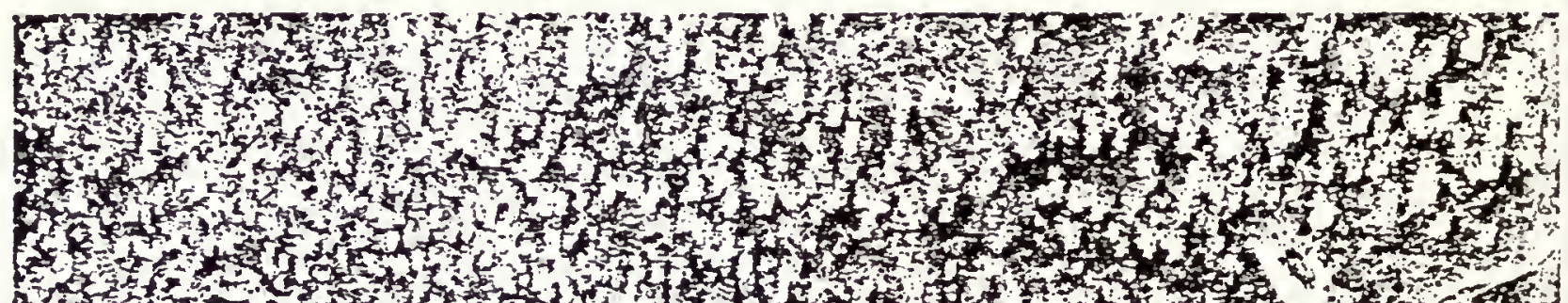
and

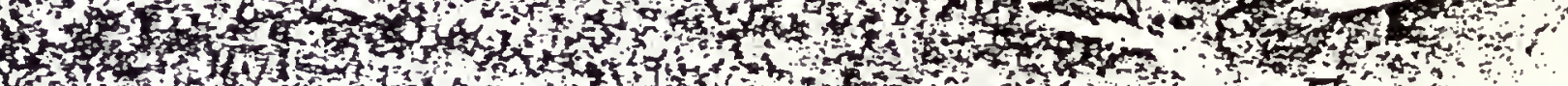
10 -

Fif

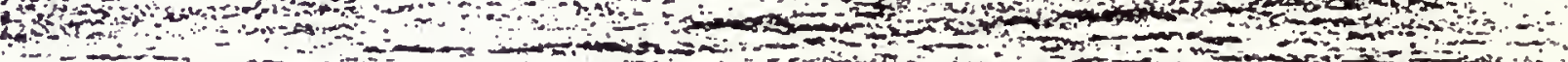

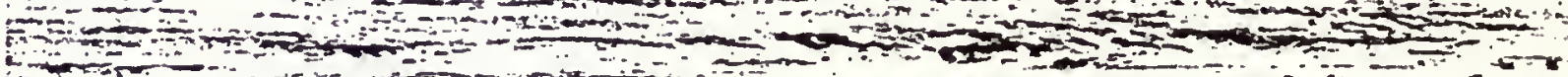

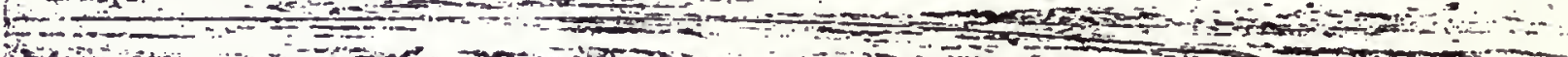

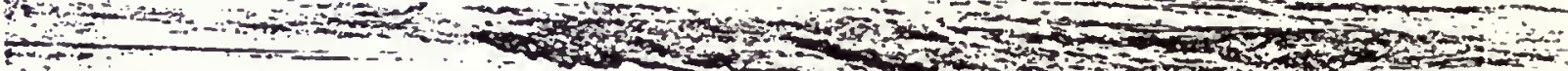

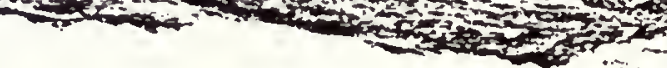

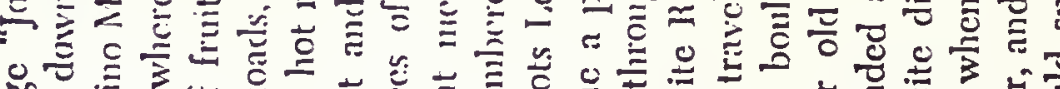

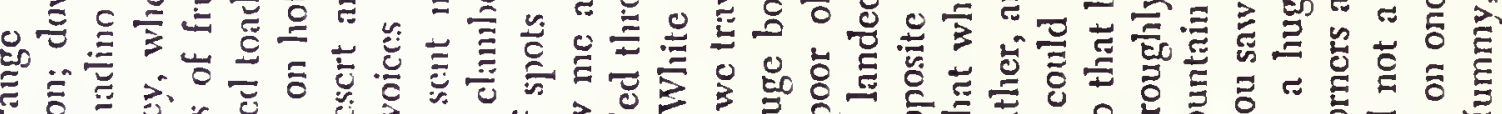

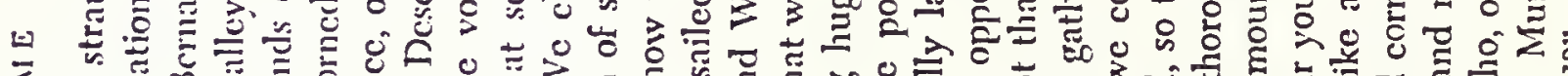
¿

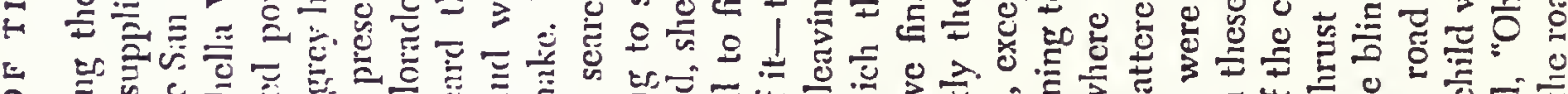
○

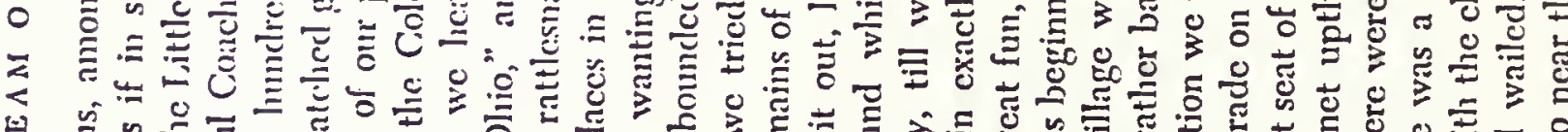
出 i

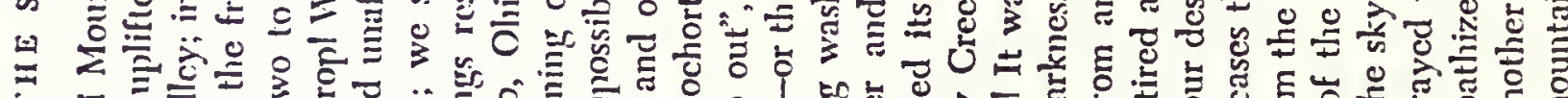

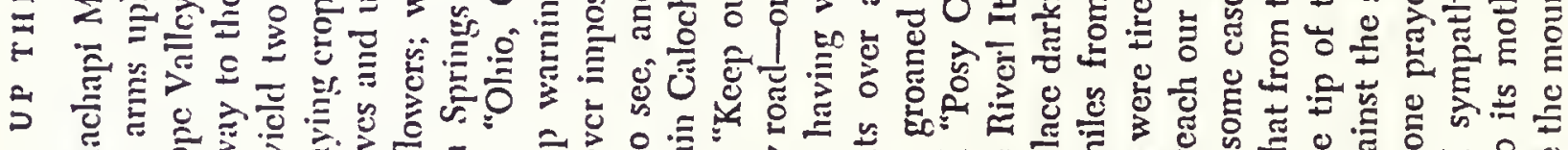

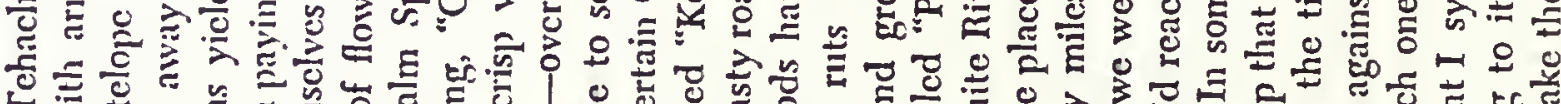

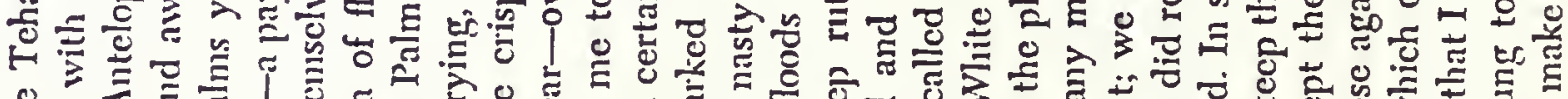

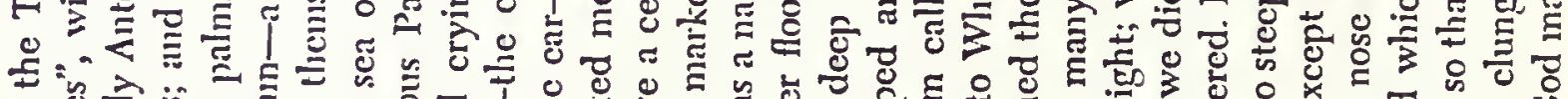

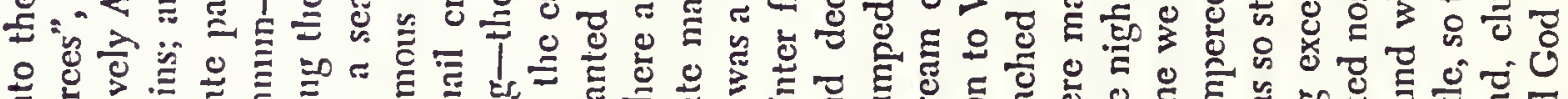

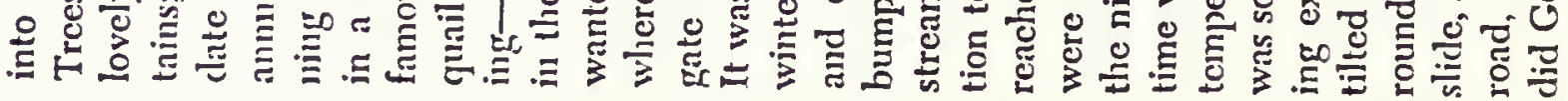




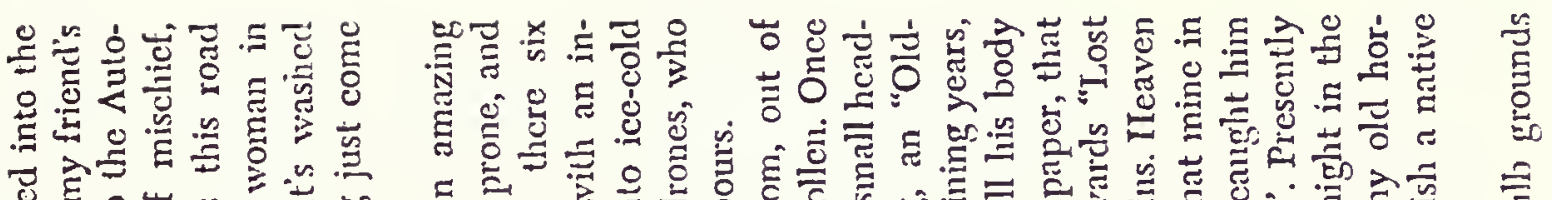

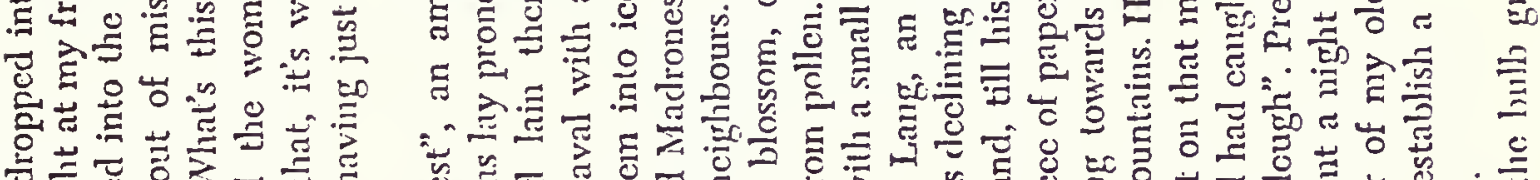

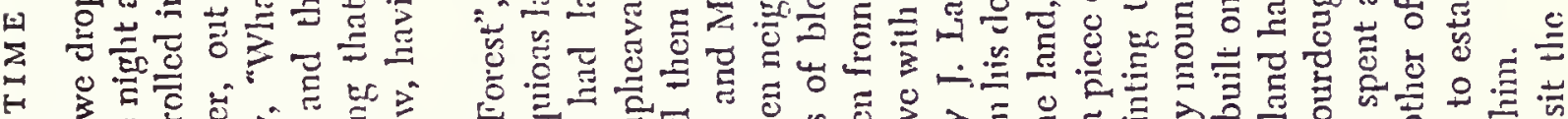

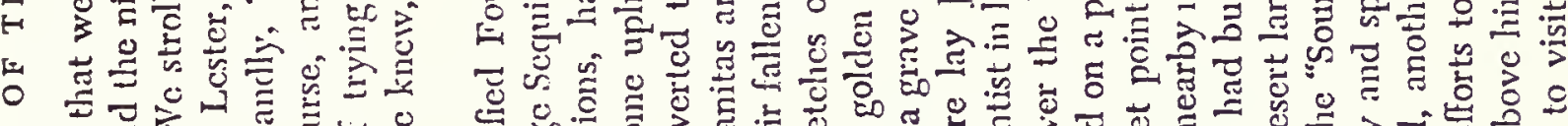
可 之 «

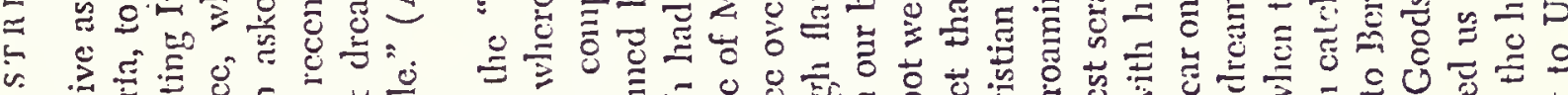

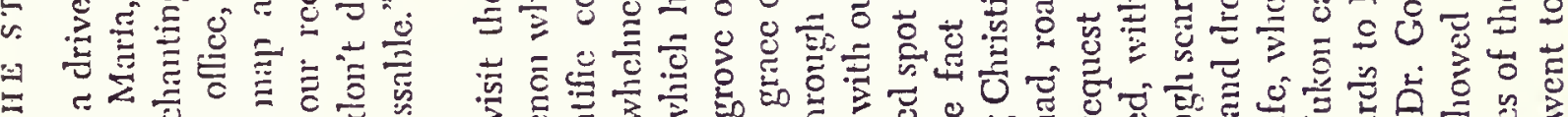
4

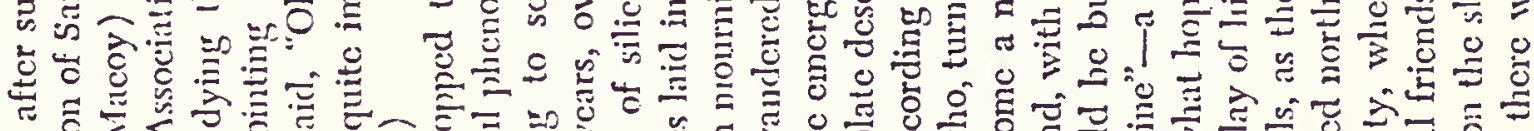

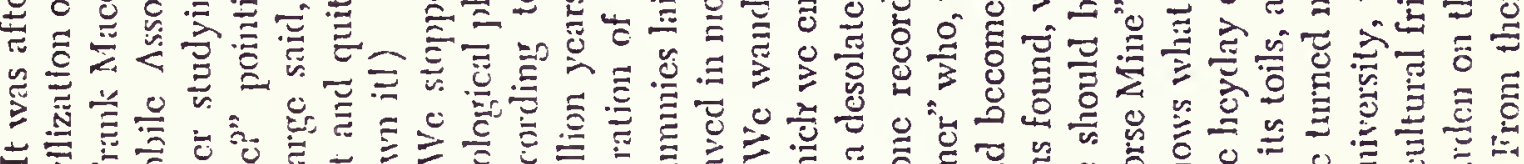

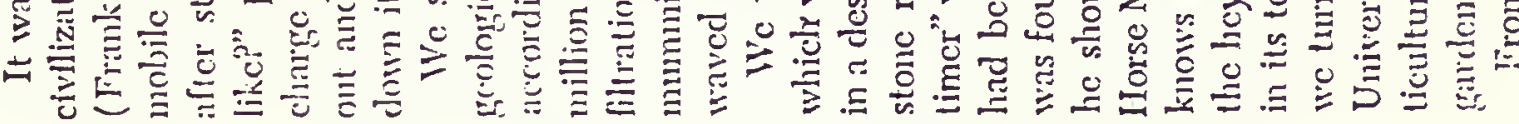




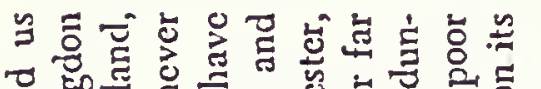

ช

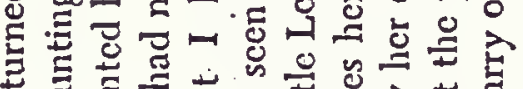

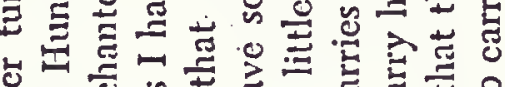

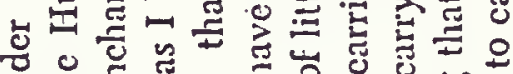

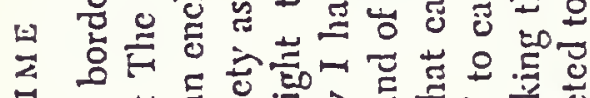

$F$ ह जै 气

。

z

$<$

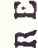

5

is

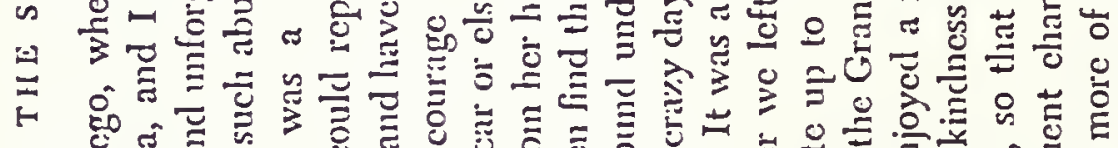

s

等

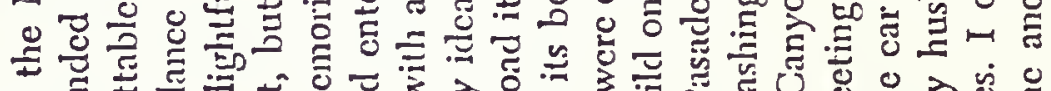

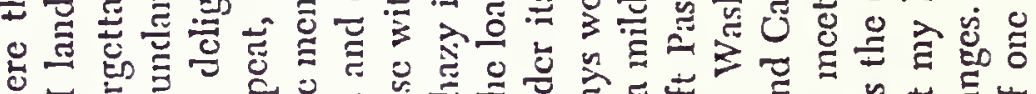

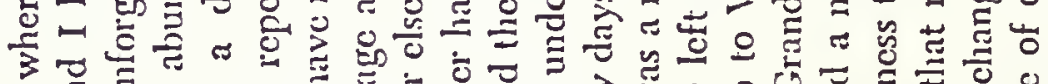

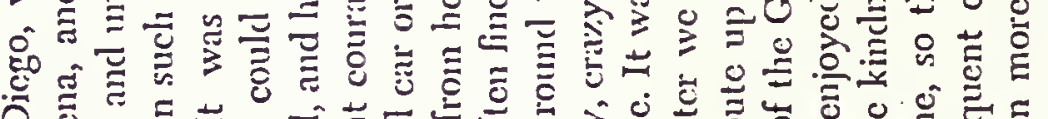
엉

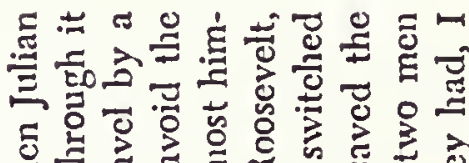

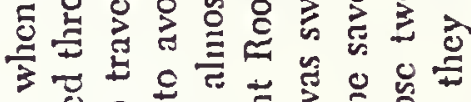

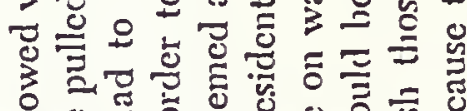
$\cong$ O. ¿

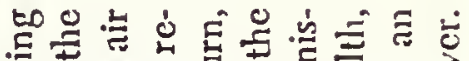

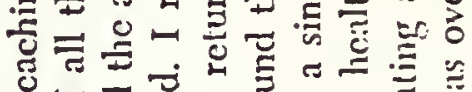

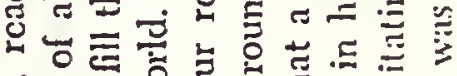

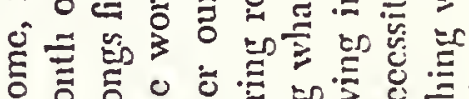

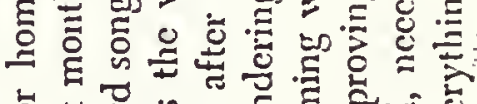

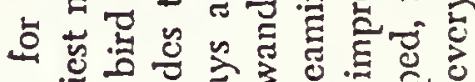

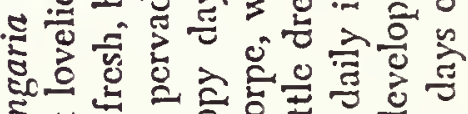
원

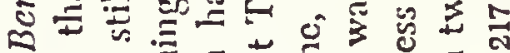
O

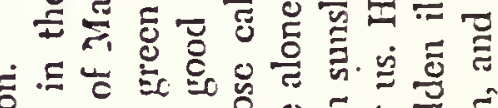

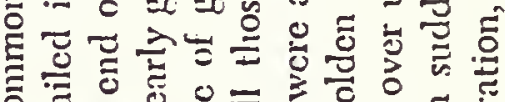

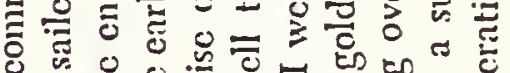

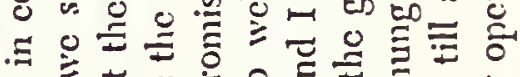

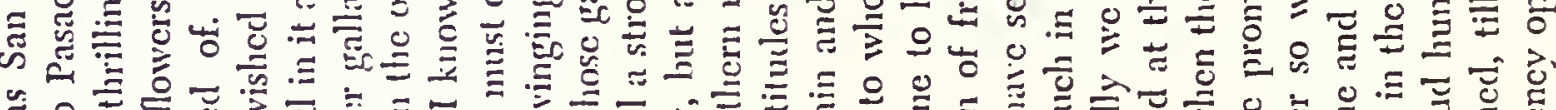

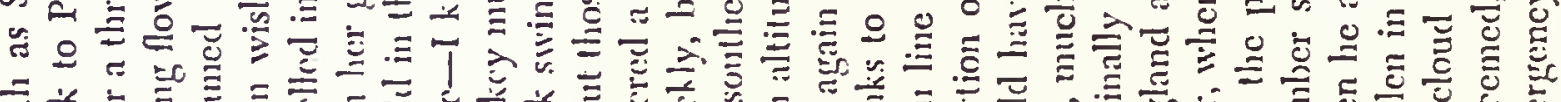

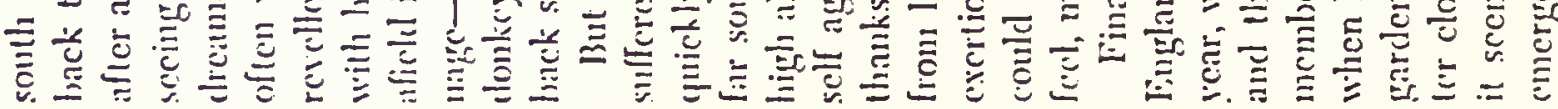

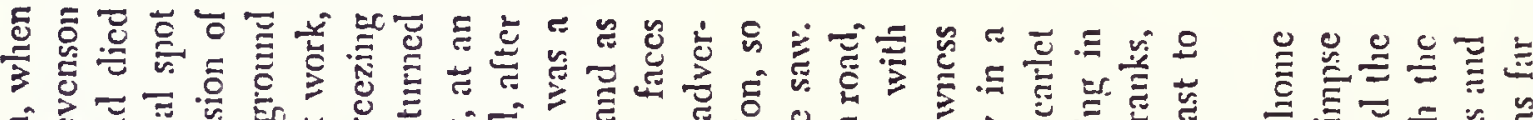
Eั

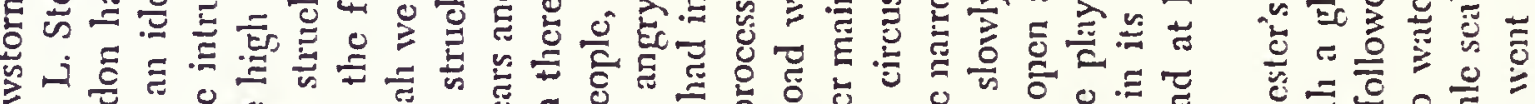
曰

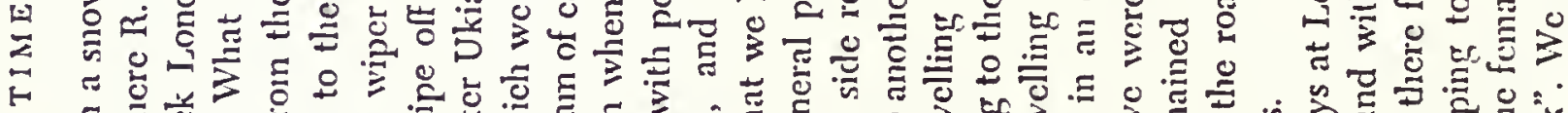

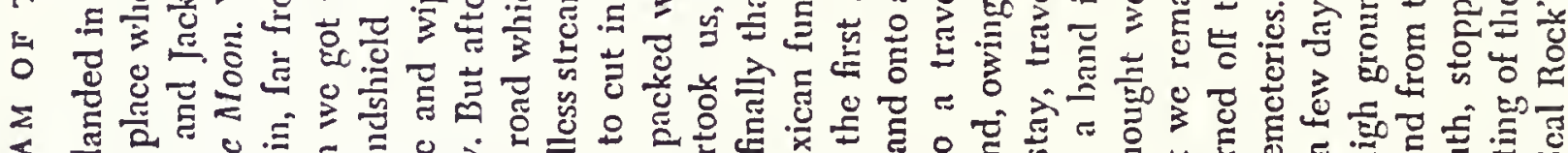

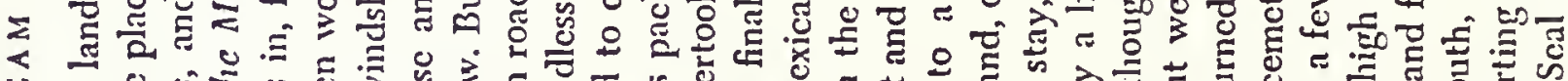

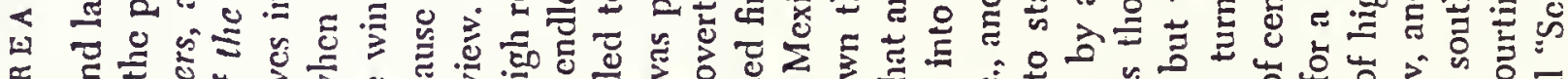

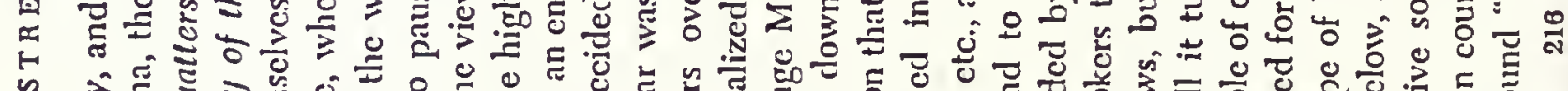

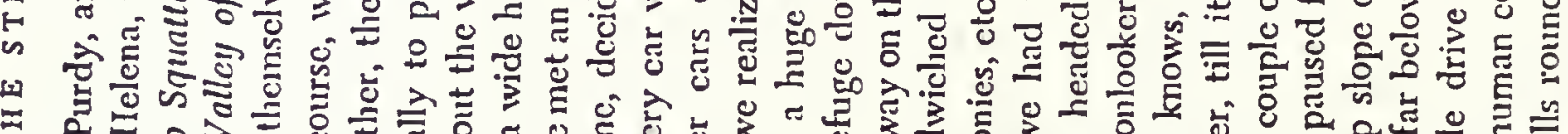
: क ⿹弋山 光芯

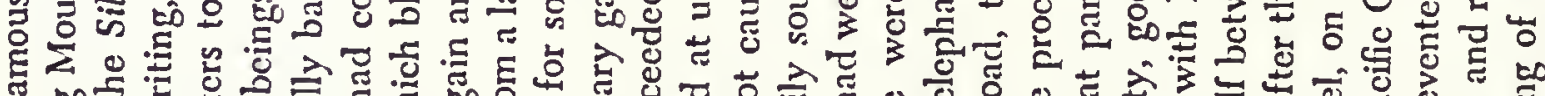

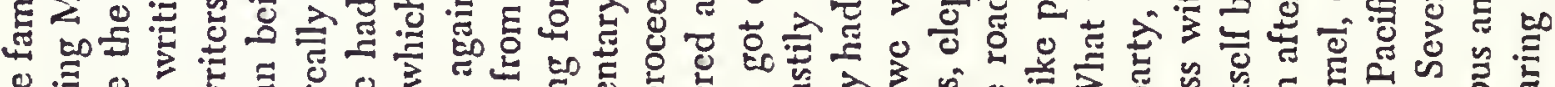

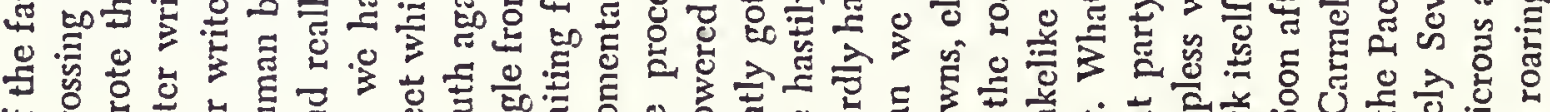

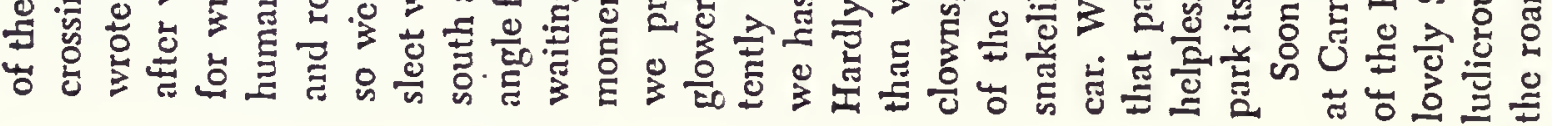




\title{
California Wild Flower Seeds
}

\author{
LESTER ROWNTREE $\otimes$ CO. \\ BOX 986 \\ CARMEL, CALIFORNIA
}

U. S. A.

List No. 4

Supersedes all previous listo

Price of packeta twenty-five cents unless otherwise indicated.

Postage prepaid in United States and Canada. Orders from foreign countries should include one cent per packet for postage.

We give or imply no guarantee as to description, purity or productiveness of our seeds, and hold ourselves in no way responsible for customers results.

Our seeds are carefully selected from native stands, but these stands are ex. posed to climatic and other conditions over which we have no control. The list is subject to change.

We suggest that our customers, particularly those ordering from a distance, send with their orders a supplementary list of second choices in case we are out of items on the first order.

In our present form of list we cannot give adequate descriptiona of flowers and of conditions of growth for each type of plant. We are glad, however, to answer correspondence regarding the cultivation and hardiness both of our listed seeds and of other native California plants.

As we generally have on hand various seeds in quantities too small for list. ing, we will be glad to have requests for sceds other than appear in our cata. log. These unlisted seeds are often used in the mixtures.

We will not dig native bulbs for sale.

Unless otherwise indicated, seeds are perennials.

Annuals are all recommended for the eastern United States, Canada and north. ern Europe. Generally speaking all listed seeds are hardy in the southern states and southern Europe. A few perennials (for instance, many of the bulbs, if mulched) are hardy in the northern latitudes, but the varieties are so limited that we prefer to feature annuals.

Unless otherwise indicated, these aeeds succeed best if given summer drought conditions after they are once established.

Please note the many varieties on our list which are adapted for seaside plant. ing.

We will be very glad to hear from experimental planters who will report to us on the hardiness of our varieties in the East.

W. L. Jepson, "Manual of the Flowering Plants of California" in our authority for the botanical names on our list. The May, 1927 National Geographic Magazine, also gives descriptions and colored illustrations of many of our varieties.

\section{MIXTURES}

Low annuals for sunny dry bare places in borders

Tall annuale for ounny dry bare places in borders

Annuals for shady places

Low annuale for damp aunny places

Tall annualo for damp aunny placea

Decorative grasses, attractive in the border and useful for cutting

Vetch and pea mixture to be used for dry sunny banks

Mixture for and dunea

Price of all mizturea, fifty cents per packet. 


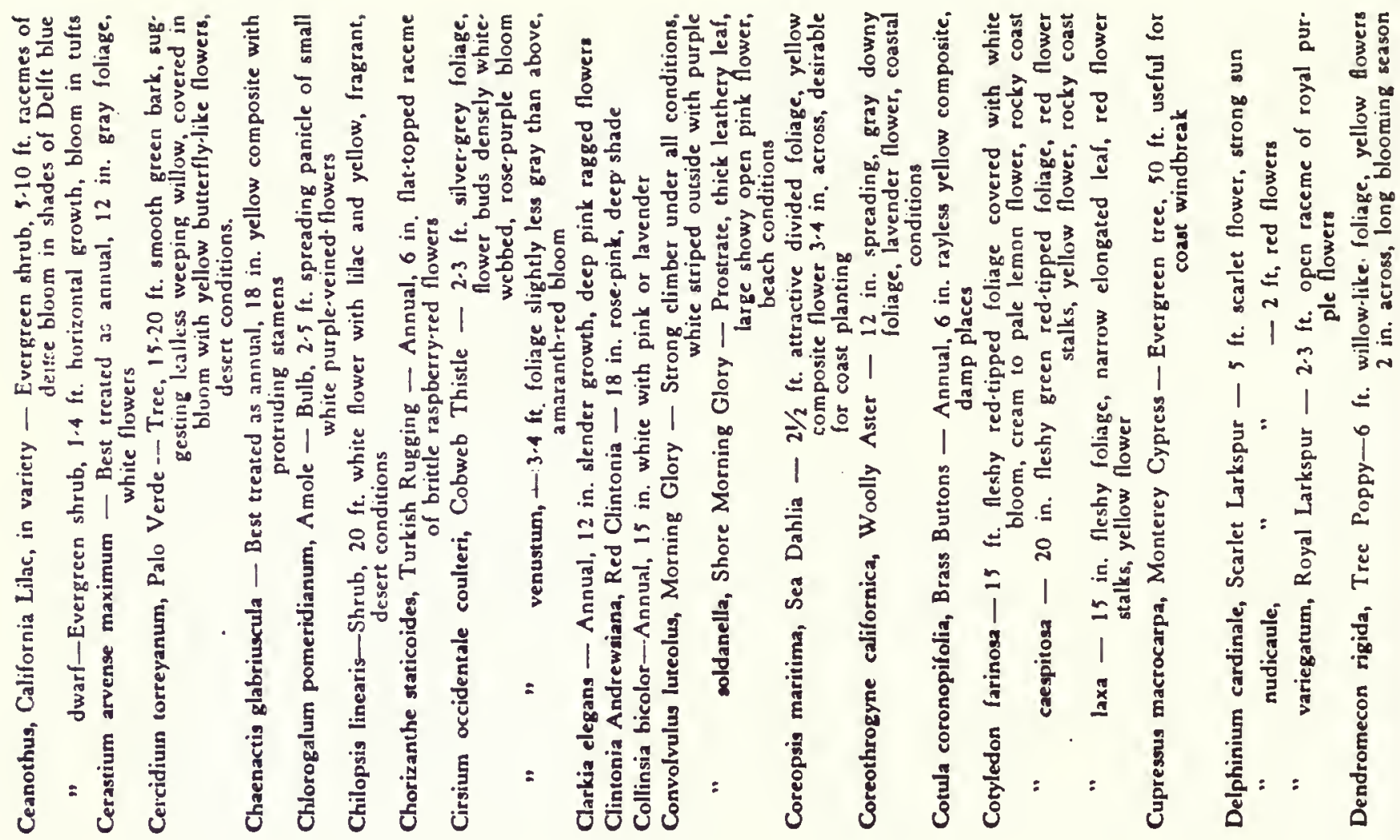

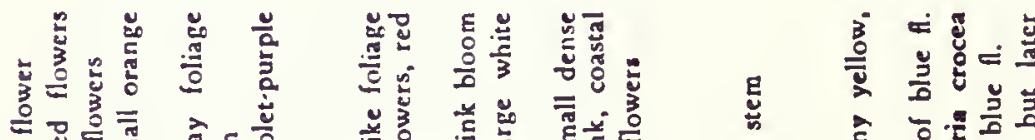

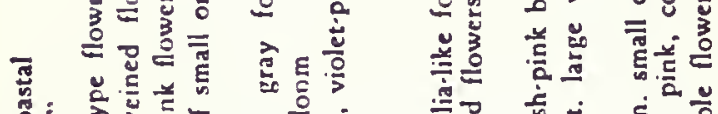

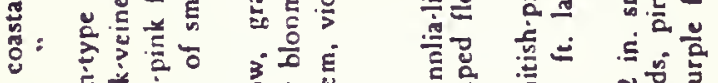

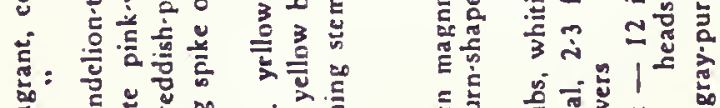

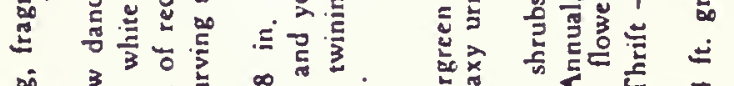

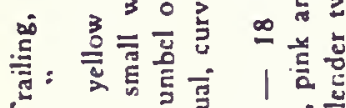

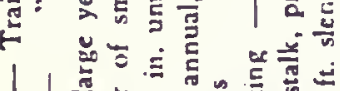

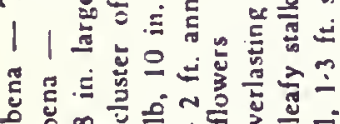

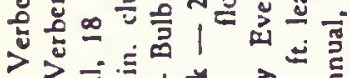

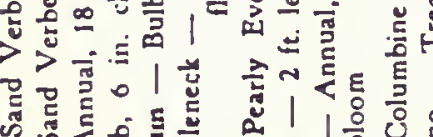

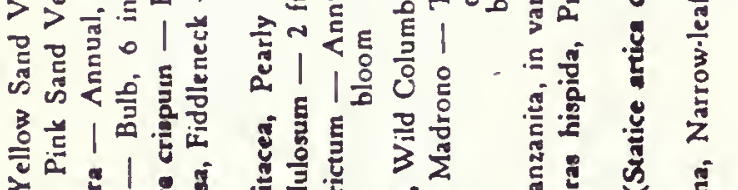

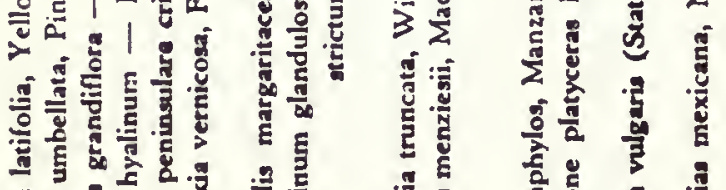

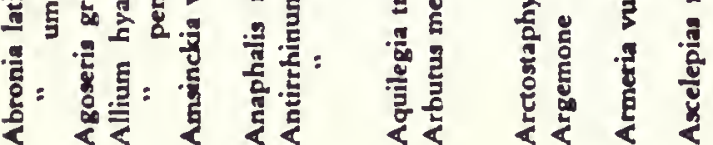

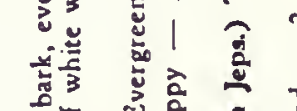

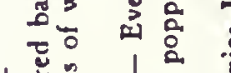

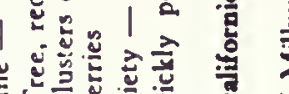

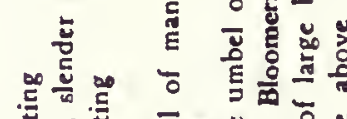

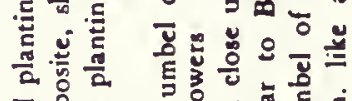

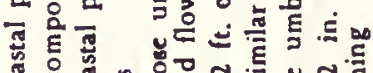

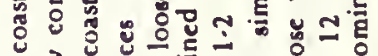

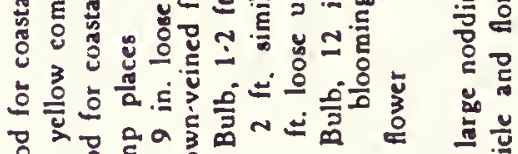

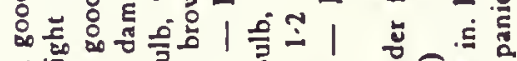

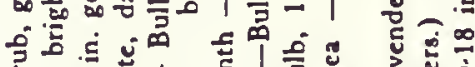

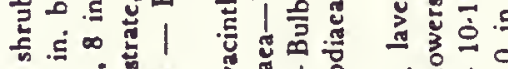

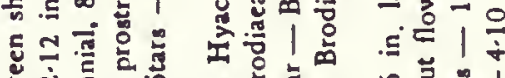

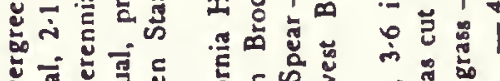

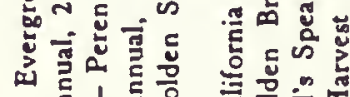

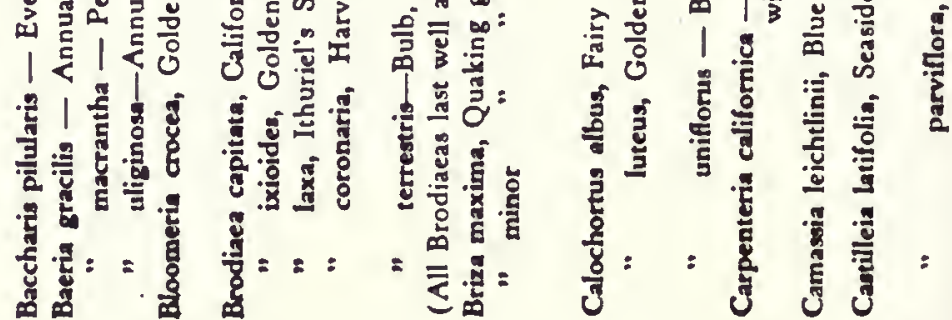

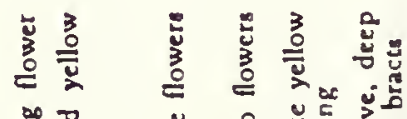

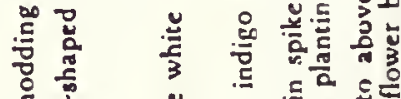

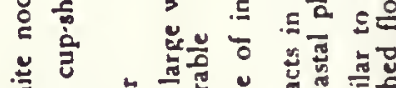
势

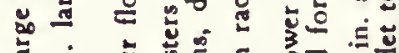
호 혼 $\infty \ldots$

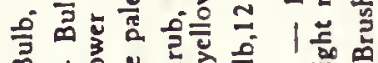

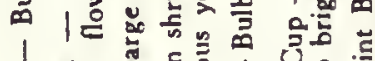
|

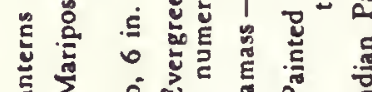

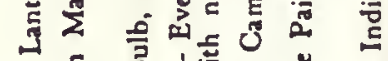
入

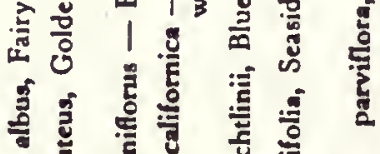

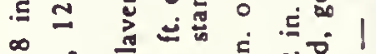


INDEX -- Lester Rowntree

Abrams, Leroy, 40, 42

aging, problems of, 121-123, 160-161, 294-295

American Friends Service Committee, 3, 11, 176, 203

American Geographic Society, 1-2

Arbegast, Mai, 273, 275

Arctostaphylos edmundsii, 65,67

Arctostaphylos pumila, 65, 67

Atascadero ( $\mathrm{Ca}.), 116,125-126$

Australian flora, 30

Bacigalupi, Rimo C., 39, 42, 47

Baileya, 15, fn.

Bancroft, Hubert Howe, 261

Bancroft Library, The, 2, 125, 187

Bartram, John, 265-266

Blake, Arthur, 67

boarding schools, $8,85,87,108-110,129,246$

Brandegee, Katherine, 35

Brandt, Cora, 267

Brewer, Leo, 49

Brower, David and Anne, 68

Bryan, Ray, 2

Burbank, Luther, 34

Byng, Viscountess, of Vimy, 20-22, 114, 200

California Academy of Sciences, 1, 3, 5, 15, 135, 151, 162, 193, 196, $261-262,270,285$

California Gardens, 17

California Horticultural Journal, 77

California Horticultural Society, 267, 273

Journal of the California Horticultural Society, 58

California native plants, 6, 11, 14-17, 26-27, 29-46, 53, 56-59, 68-69, $71,171,181,267$, and passim

California Native Plant Society, 29, 31-32, 38, 59, 73, 75, 120, 212

California State Garden Club, 18

Campbe11, Douglas Houghton, 3

Campbe11, James V., 1, 2, 27

Campbe11, Margaret, 1-28, 144, 195, 262

campo pea, 60-61

Carme1, 3,9-10, 34-35, 63-65, 96-97, 115, 118, 126, 168, 234, and passim

Ceanothus gloriosus, 268

Ceanothus impressus, 268

Ceanothus rigidus albus, 63

Century of Philadelphia Cricket, A, $266 \mathrm{fn}$. 
Chilean flora, 30

Civilian Conservation Corps [CCC], 68, 116-118, 154

Clevenger, Lila, 10, 60, 75, 112-115, 128-129, 131, 136-140, 196, 270

Collum, Rose, 269-270

compost, 23, 98, 150, 169, 216

conservation, $11-15,18,35,67,263-264$

Countryside, 264

Cunningham, Imogen, 226

Dendromicon harfordii, $44-45$

Denny and the Indian Magic, 193

Depression, the, 54, 106, 112, 126-127, 138, 154, 235

desert flora, 19-21, 93, 120, 242-243

Douglas, David, 30, 266

East Bay Regional Park Botanic Garden, 45-50, 68, 73-75, 215

Eastwood, Alice, 1-3, 15, 21, 35, 56-57, 144, 267

ecology, 167, 173, 181-183,191-192, 221, 229

Edmunds, Lewis, 63-64

Erythea, 21

exotics, $14,33,37-38,61,181,232$

Flowering Shrubs of California, 15, 32, 42, 50, 59, 69, 212, 262, 267, 272

Four Seasons, 54,56

Fremontia, 29, 262, 269, 285

garden clubs, 15,18

Gill Tract, 39, 41-42

Goodspeed, T. Harper, 22

Griffin, James, 63

Hall, Marion, 272

Hamann, Skee, 135, 259-277

Hardy Californians, $15,32,38,42,59,69,212,262,267$

Hayakawa, Margedant, 29, 262, 269

Hayes, Nancy, 2-3

Hazel, Lester, 209, 239

Hoffman, Ralph, 273

Howell, John Thomas, 3, 15, 22, 267

hybridizing, $15,34,268$ 
Iris bracteata, 49

Isenberg, Gerda, 16

Jackson, Josephine, 19-20, 119, 132-133, 162, 221, 242, 270

Jepson Herbarium, 29, 42

Jepson, Willis Linn, 15, 21-22, 40, 42, 102, 172, 187, 193

Johnson, Charles Cleveland, 259, 261

Klein, Charles, 260

KPFA, 173, 199, 201, 206

Kraebel, Charles, 40-42, 68

Laurel Hill Cemetery manzanita, 56

Leaflets of Western Botany, 21

Lester, Francis E.,

Lester, John Ashby, 265-266

Lewis, E.G., 125

London Horticultural Society. See Royal Horticultural Society

Los Angeles Times, 120, 143

Lowenthal, David, 177

McCoy, John, 19

McDougall, Walter, 259, 269

McMinn, Howard, 42, 45-46

Martin, Mr. and Mrs. Septimus, 126

Mediterranean flora, 5, 30-31, 151

Melas, Heidi Rowntree, 9, 147, 197, 199, 207-211, 213, 236-257

Miller, Henry, 214, 216

Mills College, 45

Mitche11, Sidney, 267

Morley, Christopher and Felix, 265-266

Mott, William Penn, Jr., 73-75

Muir, John, 32, 39, 78-80, 262

Munz, Philip Alexander, 42

Murphey, Edith Van Allen, 259, 276

Nash, Patricia Rowntree, 119, 147, 156, 213, 216, 246

Ornduff, Robert, 29-38, 47

Parsons, Mary, 35-36

Payne, Theodore, 31 
Penrith (England), 82

Peregrine Smith Publishers, 16, 37, 59

Perry, Charles, 264

Peterson, Roger Tory, 216

Pinchot, Gifford, 12

Purdy, Car1, 31, 265

Quaker religion. See Rowntree, Lester, religion, Quaker background

Reagan, Ronald, 74

Reinhardt, Aurelia Henry, 45-46

Reiter, Victor, 267

Rhus integrifolia, $65,182,191-192$

roadside cuts, $4,18,25,28,40,67$

Robin, Clyde, 52, 259-260, 272

Robinson, Lois, 52-53, 259-261, 277

rock gardens, $4,17,19,20,22,86,97$

Roof, James, 22, 39-80, 153

Roosevelt, Franklin Delano, 68

Roosevelt, Theodore, 12

Rowe, E. Denys "Ed", 70, 91

Rowntree, Bernard, 7, 9, 25, 28, 105-107, 114-115, 130, 135, 166, 185

Rowntree, Cedric, 7-8, 26-27, 54, 72, 87, 105-123, 146, 168, 171-174, 182, $207,246,272,280$

Rowntree, Erika, 9, 134, 189, 209-211, 239-243, 247, 254, 256-257

Rowntree, Harriette, $4-5,8-10,12,26-27,55,72,105-165,168,171-172$, $182,224-225,230,240,246-247,254,272,280$

Rowntree, Jennifer, 222, 224, 226, 228, 230-231, 233, 240

Rowntree, Lester:

and conservation, $11-15,18,31,35,67-68,289-291$, and passim and nudity, $92,145,282-283$

as author, $15-20,24-25,32,37,42,50-51,58-59,76-79,97,99,153$,

$156,181,183,193-197,219,248-249,262-263$

articles, $17,99,143,196$

burning of papers, 2-4,75-78, 139

children's books, 26, 100-101, 141-142, 157, 175-176, 211, 228, 248, 263

filing systems, 4, 6, 24-25

note taking, $5,16,194-195$

as driver, 5, 8, 12-13, 49-50, 140-141, 200, 229-230

as horticulturist, $14,31,47-49,59-62,64,97,212$

as landscaper, 19-20,61-62, 85-86, 182, 231-232, 268

as lecturer, $15,18,55,120,143,163,264,267,292$

as photographer, $12,15,47,77,223$

burro trips, $24,78-79,90,119,266$

camping, $11,14,20-21,23-24,26,43,119,129,156,191,215$ 
Rowntree, Lester:

divorce, 10, 97, 106, 108, 112-115, 133-134, 137, 227

family background, $6,82-84,135,178,265-266,271$

family relations, 7-9, 26, 87, 105-106, 108-110, 114-116, 120-123, $134-136,144-149,163-165,168-169,171-174,178,189-191,205-211,221$, $224,246,253$

flower arranging, 157-158

food preferences and fads, 7, 14, 60, 72, 151-156, 179-180, 215-216, 249, 283-285

health, $5,7-9,12,18,119,127,137,140,152-156,163,243-245$

interview with, 82-103

musical tastes, 131-132, 160, 198-199, 255-256, 286-287

philosophy, 122, 131, 159, 228, 234, 238, and passim

politics, 27, 201-202, 251-252

rapport with young people, 3, 53, 55, 68-69, 95, 120, 148-149, 178-179, 263-264

religion, 170, 176, 208, 296-297

Quaker background, 11, 85, 87, 110-11, 123, 130-131, 176, 188, 201-205, $227,239,267,274-275$

Theosophical beliefs, 109-110

seed business, 10-12, 14, 17-19, 49-50, 52, 97, 112,137-138, 270

views on Women's Lib, 132-134, 212-213, 254-255, 275, 293-294

Rowntree, Lester Bradford, 8-9, 26, 119, 162-164, 168, 172, 187-213, 215, $229,237-247,253$

Rowntree, Nancy, $187,213,217-235$

Rowntree, Rowan, 8-9, 26, 118, 119, 166-185, 215, 218-219, 222-223, 226, 234,246

Royal Horticultural Society, 17, 30

"Runaway", 135, 261, 265, 276

Santa Barbara Garden Magazine, 17, 99

Santa Maria Inn, 19, 71

seed catalogues, 4-5, 9, 17

Sexton, Veronica, 1-3

Sierra Club, 67, 284

Smith, Ralph, 168-169

South African flora, 5, 30

Stallard, Jo, 279-297

Stanford University, 3, 30, 40

Stebbins, Ledyard, 48

Steiner, Rudolph, 239

Sunset, 73,143

Taylor, Kenneth, 272

Tennyson, Lord Alfred, 84

Twentynine Palms (California), 7, 19, 119, 133, 197, 221-222, 238, 242-243 
United States Forest Service, 39-45, 68, 117-118, 167, 223

University of California, Berkeley, 21, 29, 40, 126, 187, 218

Botanical Garden, 23, 29, 35, 75

University of California, Davis, 48, 112

Van Deventer, Arthur and Ruby, 259

Vollmer, August, 45-46

Walther, Eric, 267

Watts, Alan, 204

Wells, Liliane, 26-27

West, James, 22-23

Westtown School, 8, 87, 109-110, 136-137, 190, 265, 274

West Ways, 143

Wordsworth, William, 82, 84, 95

Yadon, Vern, 52-53, 292 
Rosemary Levenson

Grew up in England; B.A. In History from Cambridge University, 1948. Graduate work in History and International Law at Cambridge and Radcliffe. M.A. in Soclology at the University of Calffornia Berkeley in 1969.

Moved to Berkeley in 1951 and worked as free-lance editor and anthropological photographer. Volunteer service in groups related to the public schools, religion, and Unfversity of California faculty wives.

Travel in Europe and the Far East. Joined the staff of the Regional Oral History Office in 1970 . 




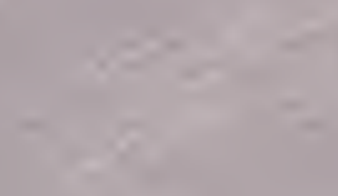

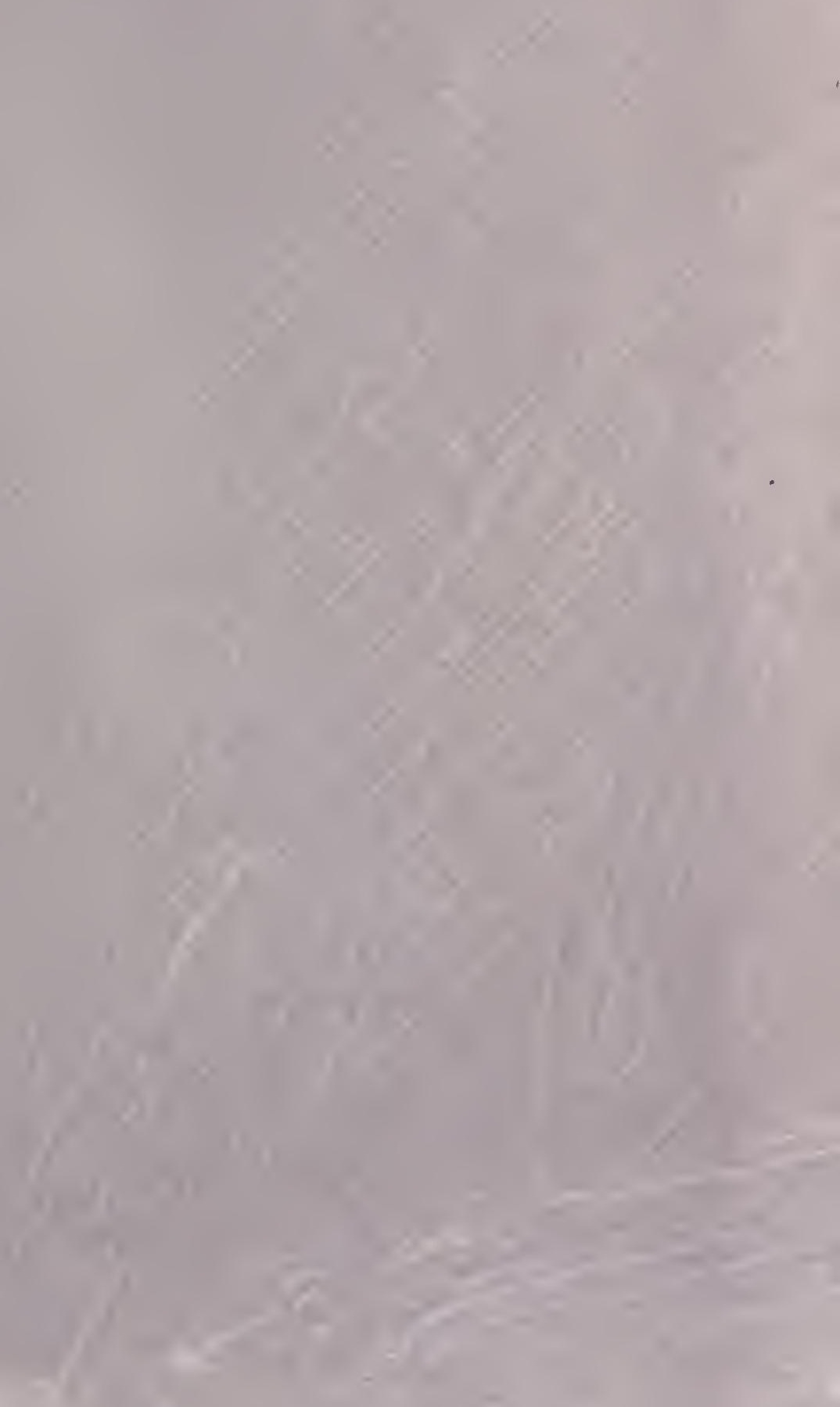





$$
30-2=0
$$

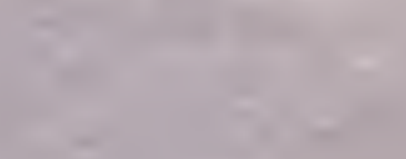

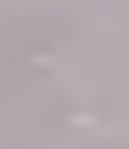

$$
x^{2}+x-5
$$
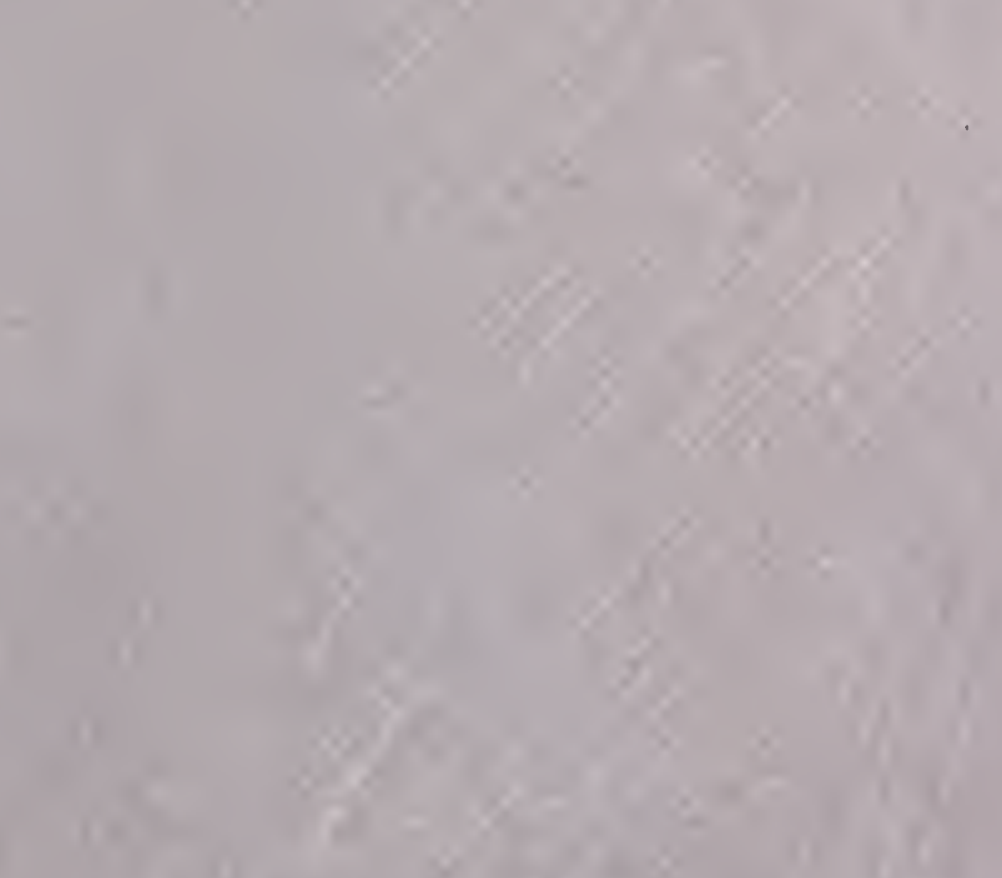

$$
62 x=167
$$

5

$$
\begin{aligned}
& +1 \\
& -2 \\
& -1,409
\end{aligned}
$$

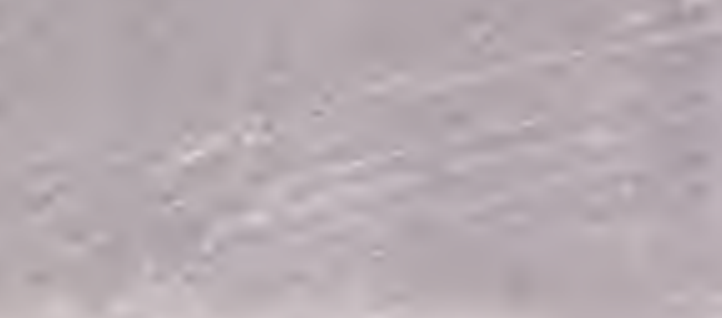


